\title{
FORESTS WOODS AND TREES
}

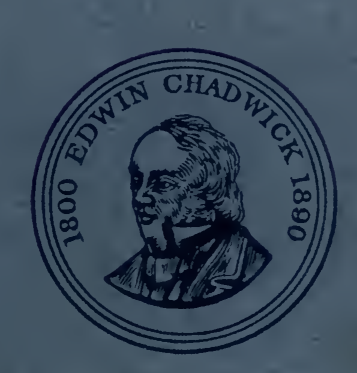




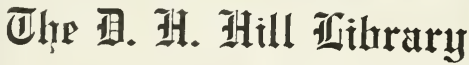

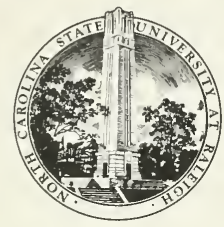

North Caralina state Alniugrsity SD 45
H 457 
This book is due on the date indicated below and is subject to an overdue fine as posted at the Circulation Desk.

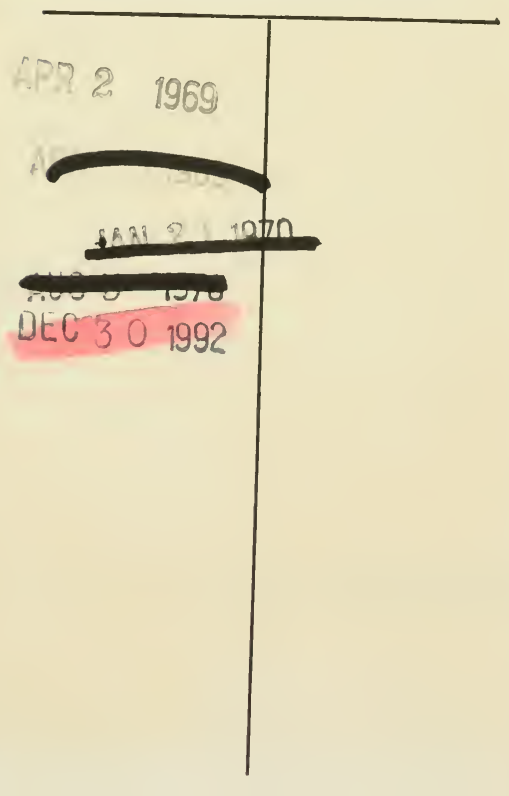



FORESTS WOODS AND TREES

IN RELATION TO HYGIENE 
THE CHADWICK LIBRARY

RAINFALL, RESERVOIRS AND WATER SUPPLY.

By Sir Alexander Binnie. 9s. net.

\section{VITAL STATISTICS EXPLAINED.}

By Joseph Bukn, F.I.A., F.S.I. 4s. 6d. net.

\section{HEALTH IN CAMP.}

By Austin T. Nankivel., M.D., Capt., R.A.M.C., with an Introduction by Sir SHIRLEY Murphy, F.R.C.S., R.A.M.C. (T.)

- Paper 1s. net; cloth 1s. 6d. net.

\section{THE FUTURE CITIZEN AND HIS} MOTHER.

By Charles Porter, M.D., B.Sc., with a Foreword by Sir JAMES CRichton BRowne, M.D., D.Sc.

3s. 6d. net.

\section{ALTITUDE AND HEALTH.}

By Professor F. F. Roger. 



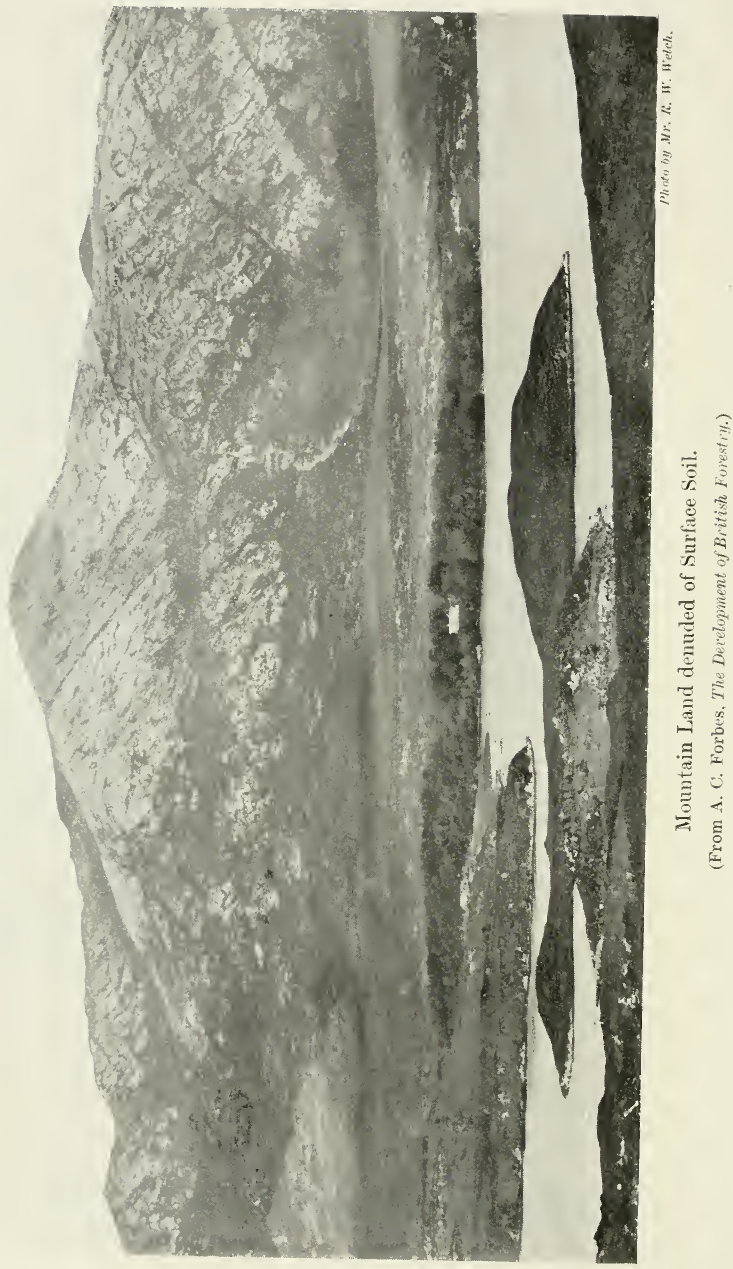




\title{
FORESTS WOODS AND TREES
}

\author{
IN RELATION TO HYGIENE
}
AUGUSTINE HENRY
M.A., F.L.S., M.R.I.A.

PROFESSOR OF FORESTRY, ROYAL COLLEGE OF SCIENCE, DUBLIN

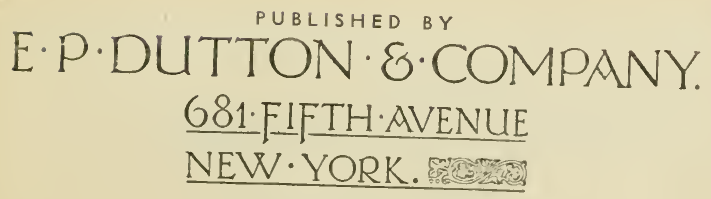

ESTABLISHED 1852 



\section{PREFACE}

THE subject matter of this book was briefly dealt with by me in three Chadwick Public Lectures, which were delivered at the Royal Society of Arts, London, in May 1917, under the title of "Forests, Woods, and Trees in relation to Hygiene."

An effort is made in this book to interest the statesman, the student of economics, the engineer, the physician, and the layman, as well as the forester, in certain aspects of forests and trees, about which vague notions are prevalent. An endeavour is made in the first two chapters to recognise and describe the far-reaching influences of forests and trees on climate, flow of water, erosion of the soil, shelter from wind, purity of air and water, etc. Such influences affect directly the health and comfort of man. The value of forest districts as sites for sanatoria and the history and utility of parks, open spaces, and trees in towns are then discussed. The afforestation of the desolate pit mounds in the Black Country and other districts is shown to be a movement of great interest, especially when, as in some cases, it is taken up by school children.

One effect of the war has been to bring home to thinking people the extreme importance of afforestation. The ancient warning, "La France périra faute de bois," is now 
applicable to this country. The concluding chapters of the book are accordingly, with great fitness for the times, devoted to a study of the afforestation of the extensive gathering grounds, from which so many of our great centres of population obtain their supplies of water. No pains have been spared in obtaining statistics and information as to the physical features, ownership, and extent of these gathering grounds. The work of planting suitable portions of these areas with the aid of disbanded soldiers might be undertaken at once, without any disturbance to other industries. Their afforestation in any case should be linked up with the general scheme of afforestation of the waste lands of Great Britain and Ireland, which it is confidently expected will be undertaken by the State as soon as peace is made. Scattered as the gathering grounds are throughout the country, they will form convenient centres for planting, more especially in the cases where their ownership has been acquired by local authorities. The compulsory purchase of catchment areas, which are not already owned by municipalities, is advisable for sanitary reasons; and the necessary legislation may possibly be introduced when afforestation by the State becomes a reality.

\section{ACKNOWLEDGEMENTS}

Much information concerning water catchment areas has been supplied by town clerks, engineers, and other municipal officers throughout the country, and to them my grateful thanks are now tendered. Messrs. J. \& A. Leslie \& Reid, Edinburgh; Mr. Joseph Parry, M.Inst.C.E., Consulting Engineer, Liverpool Waterworks; Mr. David A. Donald, Burgh Engineer, Grangemouth; Mr. C. H. Priestley, 
M.Inst.C.E., Cardiff; Mr. Frank Howarth, M.Inst.C.E., Plymouth ; Mr. S. Chapman, M.Inst.C.E., Torquay ; Mr. J. H. H. Swiney, M.Inst.C.E., Belfast ; and Ir. P. C. Cowan, Local Government Board, Dublin, contributed valuable information and aided my researches in various ways. Prof. Percy F. Kendall, Leeds University; Mr. W. B. Crump, M.A., Rastrick; Mr. Frank Elgee, Middlesbrough; Mr. G. P. Gordon, Lecturer in Forestry, West of Scotland Agricultural College, Glasgow; and Mr. James Whitton, Superintendent of Parks, Glasgow, furnished me with plans, photographs, and lantern slides, which proved very useful in the lectures given before the Chadwick Society and in the preparation of this book.

The plates illustrating the work have been borrowed from various sources, and acknowledgements and thanks are now tendered for the loan of blocks to Mr. Edward Arnold, Frontispiece, from A. C. Forbes, Development of British Forestry, and Fig. 6, from Cohen and Ruston, Smoke; to Mr. John Murray, Figs. 14 and 16, from E. P. Stebbing, British Forestry; to the Council of the Royal Irish Academy, Fig. 13, from Pethybridge and Praegcr, Vegetation South of Dublin; to Mr. P. E. Martineau, Secretary, Midland Reafforesting Association, Figs. 7, 8, 9, from Annual Reports; to Superintendent, Linford Sanatorium, Fig. 1, from Booklet; to Town Clerk, Bournemouth, Fig. 2, from Handbook; to Mr. W. H. Morter, Superintendent, Parks of Birmingham, Fig. 4, from Handbook; to Mr. Robert Anderson, Printer, Glasgow, Fig. 5, from Municipal Glasgow; to Mr. R. Galloway, Secretary, Figs. 15, 17, 22, 26, 31, 32, 33, from Transactions of the Royal Scottish Arboricultural Society; to Prof. W. Somerville, Editor, Figs. 12, 24, 25, 27, from Quarterly Journal of Forestry; to Editor, Gardeners' Chronicle, Figs. 21, 28, 29, 30; to 
viii FORESTS, WOODS, AND TREES

Editor, Country Life, Figs. 18, 19, 20, 23 ; and to the Council of the Institution of Civil Engineers, Figs, 37, 43, 44,46 .

\section{AUGUSTINE HENRY.}

Royal College of Science, DUBLIN. 


\section{CONTENTS}

CHAP.

I. The Influence of Forests on Climate . 1

II. The Sanitary Influence of Forests a 13

III. Forests as Sites for Sanatoria . . 20

IV. Parks in Towns and Municipal Forests • 33

V. Trees IN Towns . . . 44

VI. Afforestation of Pit Mounds a $\quad$. $\quad 59$

VII. Afforestation of Water Catchaent Areas 71

VIII. Conditions affecting the Planting of Water Catchiment Areas . $\quad . \quad . \quad 105$

IX. Trees for Water Catchment areas and for General Planting $\quad$. $\quad$. 119

X. Water Catchuent Areas in England and Wales . 171

Xl. Water Catchment Areas in Scotland . 247

XiI. Water Catchant Areas in Ireland . 286

INDEX . . . . . . . $\quad$. $\quad 307$ 



\section{ILLUSTRATIONS AND MAPS}

F10.

PAGE

Mountain Land denuded of Surface Soil . Frontispiece

1. Sleeping Chalets in Wood at Linford Sanatorium, New Forest

Facing 20

2. Pine Walk in Central Gardens, Bournemouth . " 21

3. Map : Mid-Lanark, Camps Catchment Area Aftorestation Scheme

4. Students' Garden, Camnon Hill Park, Birmingham Facing 40

5. Ardgoil Estate, Head of Coilessan Glen . . " 41

6. Stoma of leaf of Silver Fir, showing deposit of soot $\quad 54$

7. Map : Parks and Spoil Banks, Black Country . . 61

8. Typical Pit Mound at Littleton Street, West Bromwich . . . . . . . Facing 64

9. Doulton Road School Plantation . . . ” 65

10. Map : Liverpool Corporation, Lake Vyruwy Plantations . 90

11. Map: Manchester Corporation, Thirlmere Plantations . 97

12. Plan: Leeds Corporation, Afforestation Scleme of Washburn Valley . . . . . Facing 100

13. Agrarian, Dwarf Furze, and Heather Zones, Dublin Mountains. . . . . Facing 106

14. Thirlmere Catchment Area, general view . . " 112

15. Mattock Planting on Thirlmere Catchment Area . " 112

16. Talla Catchment Area, planting, April 1914 . ” 113

17. Belgian Method of planting Peat: four rows of inverted turfs between the drains Facing 113

18. Maritime Pine, three years old, sown on bog at Abbeyleix . . . . . Facing 126

19. Maritime Pine, five years old, sown on bog at Abbeyleix . . . . . Fucing 126

20. Maritime Pine, forty-seven years old, at Mullaghmore " 127

21. Douglas Fir plantation at Taymount . . " 132 
22. Plantation of Tsuga Albertiana at Murthly

23. Forest of Western Larch in Idaho

24. Japanese Larch, planted nine years

25. European Larch at Langley Park .

26. Sitka Spruce at Durris, Kincardineshire .

27. Beech at Ashridge Park

28. Abies nobilis plantation at Durris, with a few oak standards

overhead; Japanese Larch in the background . Facing 146

29. Cupressus macrocarpa, nineteen years planted, in Phoenix Park, Dublin . Facing 147

30. Thuya gigantea plantation at Benmore

31. Thuya gigantea as shelter tree on plantation margin

32. Populus regenerata at Glasnevin 166

33. Populus Eugenei at Kew .

34. Map : North of England Catchment Areas

35. Map: Lancashire Catchment Areas

36. Map: Yorkshire, Cheshire, and Derbyshire Catchment Areas

37. Plan: Blackburn. Brennand and Whitendale Catchment Area.

38. Map: Longdendale, Derwent Valley, and neighlouring Catchment Areas

39. Map: Midland and Severn Valley Catchment Areas . 213

40. Map: Somerset, Devon, and Cornwall Catchment Areas . 223

41. Map : Wales Catchment Areas . . . 231

42. Map: West, Central, and South Scotland Catchment Areas 248

43. Plan: Edinburgh. Glencorse Burn Catchment Area . 266

44. Plan: Edinburgh, Talla Water Catchment Area. 268

45. Map: Clackmannan, Fife, East Perth, and Forfar Catchment Areas . . . . . . 273

46. Plan: Kirkealdy District. Slateford Burn and River Farg Catchment Areas . . . . . . 278

47. Map: Inverness, Ross, and Aberdeen Catchment Areas . 283

48. Map: North Ireland Catchment Areas . . . 288

49. Map : South Ireland Catchment Areas . . . 297 


\section{CHAPTER I}

THE INFLUENCE OF FORESTS ON CLIMATE

THE influence of forests on climate is undoubted, though perhaps less than is generally supposed. The subject is a difficult one to study; and on many points no agreement lias been arrived at amongst engineers and foresters. The latter usually hold that the presence of forests is beneficial, in increasing the amount of rain in a district or country, and in diminishing the erosion (Frontispiece) and the consequent great losses of the soil on hill and mountain slopes. The foresters agree with Humboldt's saying: "How foolish is man in destroying the mountain forests, as thereby he deprives himself of wood and water at the same time."

The desolation that now prevails in parts of Spain, Algeria, and other Mediterranean lands is generally ascribed to the gradual drying up of the climate, consequent on the lessened rainfall brought about through the steady clearing of the forests by human agency. It is, howeter, well established that great climatic changes of cosmic origin occur in the course of centuries; and the disappearance of the forests in those countries may be possibly not the cause but the result of lessened rainfall in the present epoch as compared with Roman times.

Numerous observations taken over short periods of years in France, Germany, and the United States show that forests exert in the districts which they cover a definite influence on the temperature of the air and of the soil, on the rainfall, on the melting of the snow, on the water supply 
and stream-flow, and on the erosion of the soil on slopes of hills and mountains. The positive results of these observations, which are detailed below under separate headings, may be considered to hold good with regard to the British Isles and temperate regions generally. It is only fair to state that the beneficial action of the forest in increasing the rainfall, in diminishing the run-off water, and in preventing the erosion of the soil is not universally admitted. The main arguments against the ordinary view were published by H. M. Chittenden (1) in 1908. The attention of foresters and engineers may also be directed to the important monograph, entitled Boschi $e$ Acque, which was published at Rome in 1916 by M. Giandotti (2), Director of the Hydrographic Office of the river Po. This is a complete study of the whole question of the relation of forests to rainfall and stream-flow.

The investigations carried out in India on the influence of forests on atmospheric and soil moisture, which have been the subject of a recent official report (Indian Forest Bulletin, No. 33, 1916), throw no new light on the problem as regards tropical regions. The general conclusions arrived at in India were: "The influence of forests on rainfall is probably small, but the denudation of the soil, owing to the destruction of forests, may be regarded as an established fact in India." Dr. Gilbert Walker, in an appendix to this bulletin, points out the difficulty of such investigations, one cause of error being the tendency of the annual rainfall to run in spells of excessive and deficient years, so that the exact influence of forest growth or of forest destruction is not readily arrived at. Dr. Hugh $\mathrm{R}$. Mill, in Nature, 2nd August 1917, p. 446, advocates a study of the relation of the isohyetal (3) lines to the configuration of the land on wooded and treeless districts of similar character; and instances from the report of the rainfall in the Geological Survey's Water Supply Memoirs on Hampshire that the district of the New Forest shows a considerably higher general rainfall than its elevation above sea-level appears to suggest. It will be convenient to state now under four distinct 
headings the various ways in which forests affect climate in temperate regions, as determined by observations taken in France, Germany, and the United States.

1. The Influence of Forests on Temperature of the Air and of the Soil.-The mean annual temperature of the air inside a forest is lowered about $1^{\circ} \mathrm{F}$. on an average. This cooling effect occurs mainly in summer, and is not noticeable in winter. It is owing to the lowered temperature of the air over wooded areas that balloons are observed to sink immediately after they begin to move over a forest. The temperature of the air inside a forest is, however, raised at night; and as a result, spring and autumn frosts are much less frequent and less disastrous in wooded tracts than in the open country. A richly afforested country has a lower temperature in summer than a neighbouring country that is bare of trees in the same latitude. Bosnia, which is covered with forests, is $4^{\circ} \mathrm{Fahr}$. cooler in summer than denuded Herzegovina. The soil of the forest is warmer in winter (about $2^{\circ} \mathrm{F}$.) and cooler in summer (about $5^{\circ}$ to $10^{\circ} \mathrm{F}$.) than agricultural land outside. The relative humidity of the air in the forest is greater than that in the neighbouring open country.

2. The Influence of Forests upon Rainfall.-This is a difficult and complicated subject, as the effect of forests on the total amount of rainfall over a whole country is doubtful. In the British Isles and Western Europe, where the evaporation from the Atlantic Ocean plays the most important part in the precipitation over the land, the effect of afforestation in increasing the general rainfall is probably negligible. Where the precipitation over the land comes from the land itself the effect of forests may be considerable. The forest evaporates more water than any other kind of vegetation cover, and much more than free water surfaces, like seas and lakes. "An oak forest at Mariabrunn near Vienna, which was 115 years old, was found to evaporate daily, by transpiration through the leaves, about 2500 gallons of water per acre, corresponding to a rainfall of 3.5 inches per month, or a rainfall of 17.5 inches during a 
growing period of five months." This shows how much moisture is passed into the air by a wooded area. Forests thus enrich with moisture the winds that pass over them, and contribute to the humidity of the regions into which the prevailing winds pass. The usefulness of large forests in the interior of great continental regions like the United States, in regard to rainfall, is thoroughly explained by Dr. R. Zon, in an important article on "Forests and Rainfall" in Science, xxxviii. p. 63 (1913). He advocates the protection of such forests; whereas swamps, which contribute less to the moisture content of the air, ought to be drained. When a forest is cut away, he recommends that the cleared ground should be devoted to intensive cultivation, as after trees, crops contribute most to the moisture of the air. Vezozkii (4) holds similar views in regard to Russia, namely, that the forests ought to be preserved in the regions which abound in moisture and lie in the route of the air currents carrying moisture.

The influence of forests upon local precipitation has been determined by observations taken at Nancy in France over 33 years. These show an excess of precipitation in the forested areas of 12 to 23 per cent. As Huffel says, the forest always increases the frequency and abundance of atmospheric precipitation. It rains more in the centre of a great forest than at the margin, and more on the edge of the forest than at some miles distant over agricultural land. This action of the forest in increasing rainfall is much more marked in the mountains and at high altitudes than in the low and level plains. This is well shown by the following table, taken from over 200 stations during a period of ten years in Prussia:

Altitude of Stations

\begin{tabular}{|c|c|c|c|c|c|c|}
\hline & $\begin{array}{l}\text { Below } \\
300 \mathrm{ft} \text {. }\end{array}$ & $\begin{array}{l}330 \text { to } \\
650 \mathrm{ft} \text {. }\end{array}$ & $\begin{array}{l}780 \text { to } \\
1300 \mathrm{ft} .\end{array}$ & $\begin{array}{l}1970 \text { to } \\
2300 \mathrm{ft} \text {. }\end{array}$ & $\begin{array}{l}2300 \text { to } \\
2600 \mathrm{ft} \text {. }\end{array}$ & $\begin{array}{l}3000 \text { to } \\
3250 \mathrm{ft} \text {. }\end{array}$ \\
\hline $\begin{array}{l}\text { Rainfall in inches of } \\
\text { stations in the forest. } \\
\text { Rainfall in inches of } \\
\text { ordinary stations. }\end{array}$ & $\begin{array}{l}25 \cdot 9 \\
25 \cdot 5\end{array}$ & $\begin{array}{l}26 \cdot 2 \\
22 \cdot 9\end{array}$ & $\begin{array}{l}29 \cdot 4 \\
27 \cdot 4\end{array}$ & $\begin{array}{l}42 \cdot 9 \\
36 \cdot 0\end{array}$ & $\begin{array}{l}55 \cdot 5 \\
38 \cdot 6\end{array}$ & $\begin{array}{l}69 \cdot 9 \\
37 \cdot 9\end{array}$ \\
\hline
\end{tabular}


This shows that at elevations of less than 300 feet the rainfall was the same as in the open country; but that with increasing elevations the rainfall in the forest exceeded more and more that in unforested localities; thus at 3000 feet elevation the rainfall was 84 per cent more in the forest.

The effect of local afforestation is to increase the rainfall in the district. This has been proved by observations taken in several localities, one being a moorland in Hanover, and another a considerable area in the southern steppes of Russia, which were planted with trees. Rain-gauges were placed inside the planted tracts and in the surrounding country; and as the plantations were increased year by year, the rainfall recorded in them was found to be gradually augmented.

3. The Influence of Forests upon Melting of Snow.-Prof. J. E. Church (5), Director of the Mount Rose Observatory, Nevada, U.S.A., has made interesting researches into the restraining effect of forests on the melting of snow. He has devised new methods of rapidly and economically measuring large areas of snow at high altitudes. In the Sierra Nevadas a larger quantity of snow accumulates in forests than on bare slopes, the forests that retain snow best being those with open narrow glades. There can be no longer any question of the direct influence of forests in delaying the melting of snow and in retarding stream-flow at the very time when floods normally occur. The forested slope contains an average water-content (the snow being converted into an equivalent amount of water) one-fifth greater than the bare but protected slope above it, nearly twice as much water as the cornice at the edge of the mountain, over fourteen times the moisture conserved by the wind-swept slope, and more than twice the average water-content of all three areas combined. Prof. Church advocates the planting of timber screens at strategic points on exposed slopes in order greatly to increase their capacity to store more snow. There are thus two types of reservoirs: the snow reservoirs formed by the forest to hold the snow in its original form, 
and the water reservoirs below to impound the flood waters of the stream. The development of the former is the immediate and feasible task of the forester, the construction of the latter is the work of the engineer. Prof. Church's investigations open up a new field for planting trees at high altitudes with a view of lessening the volume and frequency of disastrous floods, which are due to rapid melting of snow in the mountains from which they take their source.

4. The Influence of Forests on Water Supply, on Floods, and on Soil Erosion.-The most important action of the forest probably is its influence on water supply or stream-flow. We must distinguish the great difference of this influence in the plain and in the mountain.

Only a part of the precipitation is available for water supply. Of the total rainfall over an area,

(1) a part is intercepted by the foliage of the trees and evaporated;

(2) a part is evaporated from the soil ;

(3) a part is absorbed by the trees and other plants, and is partly transpired by them;

(4) a part flows directly off the ground, joining immediately a stream or river; this is known as the run-off;

(5) the remainder of the rainfall sinks into the ground, and joins the stratum of underground water, ultimately going to supply springs and streams.

On level land the total loss of water from these various causes, interception, transpiration, and evaporation, is somewhat greater from the forest than from any other cover, and is less from bare soil, where it is about 50 per cent of the rainfall. The surface run-off in level comntry is negligible, and a bare soil would retain the greatest amount of water for wells, etc. As a net result, in the plain, the forest acts as a drainer of the soil. Hence, the action of plantations of woods and trees in draining marshy ground is often of considerable hygienic value. The total effect of forests or woods on the springs and water supply in the level country may, however, be looked on as of little importance. 
In hilly and mountainous regions there are numerous springs, and the underground water is in motion. On slopes the run-off water, that is nil or negligible in the plain, becomes large in quantity. The action of the forest is to reduce the surface run-off to percolation. This action depends on the litter and humus of the floor of the forest, which act like a sponge absorbing four or five times their weight of water. There is practically no surface run-off from wooded watersheds having an abundant leaf-mould and litter. This water then sinks slowly into the ground, ultimately to re-appear in the springs lower down the valley. Similarly, forests preserve the snows many days longer than in the open country; their melting becomes very gradual, and the run-off is stopped or diminished. On a bare slope, on the contrary, the run-off is very great, so that immense quantities of water reach the rivers in a short time, causing often disastrous floods. Forests thus, by diminishing or stopping the run-off, increase in hilly and mountainous regions the quantity of water that percolates into the ground and ultimately re-appears as springs. At the same time the forest preserves the soil on slopes from erosion. In deforested mountains torrents carry enormous quantities of soil, rocks, and stones into the rivers, which may become silted up and useless for navigation.

Floods, besides being very disastrous financially, as they may cause much destruction of buildings, bridges, railways, etc., as well as permanent injury by silting over tracts of good land, are often serious to public health. There may be loss of life and suffering and sickness caused by exposure and privation. Damage may be done to systems of drainage, sewerage, and water supply, thus affecting injuriously the health of a city or community. Not unfrequently an epidemic follows a flood.

The great diminution of the run-off water in forests is due to various causes. The rain falls more gently, owing to the obstruction of the foliage; its flow is impeded by the roots of the trees; and it is absorbed as fast as it falls by the deep layer of humus and litter on the soil. It must be 
remembered that when there occur abnormally heavy precipitations or long-continued rains, the forest floor will become saturated and be unable to absorb more water, so that disastrous floods may occur even in the best forested areas. The forest, however, plays an important part in preventing a certain proportion of the otherwise inevitable floods; and its effect on the supply of water to springs is undoubted. Forests are efficient to a high degree in preventing erosion of the soil, formation of torrents, disastrous floods, and the filling up of the beds of rivers with silt. In channels filled with sediment even a slight rainfall may cause a flood, hence the utility of the forest in keeping streams and rivers deep and capable of carrying away unusual quantities of rain.

The effect of deforestation in increasing the number and seriousness of floods was well shown by M. O. Leighton (6) in 1909 , who proved that floods in the United States had been increasing in most rivers, no other cause being discernible than the continuous felling of timber in the upper part of their watersheds.

It is the absorbent nature of the ground that determines whether or not a larger or smaller proportion of the rainfall and snow will run off directly into the river. A large proportion is a flood. None of the conditions in the river basins studied by Leighton appeared to vary, except the surface vegetation, as the climate, topography, geology, etc., remained unaltered. The variation in the surface vegetation was the continuous reduction of the forest area by felling timber in the river basins. The watersheds studied were those of three tributaries of the Ohio River in its upper drainage area. During the last 20 to 30 years, there was an increase of floods; and when the variation in the annual rainfall has been allowed for, Leighton's diagrams show that the only factor that could have had any influence in increasing the floods was the constant and rapid deforestation that had been carried on during the period in the three river basins.

Hall and Maxwell (7), who studied the conditions of 
the watersheds in the Appalachian Mountains, confirm Leighton's conclusions. These investigators attribute the great increase in the frequency and duration of the floods in the rivers originating in this region, to the clearing away of the forests on the mountain watersheds of the streams. They strongly urge the preservation of the forests around the headwaters of the rivers. Their researches brought out the interesting fact that the increased run-off due to forest clearance diminished the evaporation over the watershed, and in consequence lessened the local rainfall. In other words, the rivers were found to discharge more water, though the rainfall over the watershed had decreased. This result, however, was to be expected, because if, as already shown, the presence of forests increases local rainfall, then their clearance will diminish it.

Forest cover has been lately shown to have a distinct and measurable effect upon navigable streams in Pennsylvania. This question had to be decided by the U.S. Geological Survey before the Forest Service could purchase under the Weeks Law any land in the White Mountains. The report drawn up by Mr. Leighton (8) gives the result of his observations on two small adjoining watersheds in this region, precisely similar in area, shape, aspect, and geology, but differing in vegetation. One watershed was covered with virgin forest; the other, which had been cleared of all its timber and burnt over subsequently, bore only a cover of brushwood. Measurements of precipitation over the areas and of the run-off of the respective streams show that not only was the snow held better in the forested area, but that during a period of 17 days in April, including three extended storms, the run-off of the stream in the deforested area was a comparative flood, practically double that of the stream flowing through the forested area.

The action of forests in diminishing floods of rivers is not universally admitted. The observations of E. V. Oppokov (9) on the relation of the river Dnieper to rainfall, etc., from 1876 to 1908 , seem to controvert Leighton ; but are probably explained by the difference between the 
Russian river in the plain and the American rivers in the mountains. Oppokov's conclusions are as follows: The flow of the Dnieper is closely related to the amount of rainfall in the whole basin. Rainfall and evaporation are the most important factors influencing the level of the river. The influence of woods and also of peat-bogs has been greatly over-estimated. He even believes that a considerable amount of vegetation in a river basin may lower the level of a river owing to the amount of evaporation set up, and says that the best conservers of water are not peat-bogs or forests, but beds of sandstone.

Mr. Cecil H. Roberts, C.E., has made investigations on the climate and physical features of the basin of the river Dee, in connection with proposals for the extension of the Aberdeen Waterworks. These investigations are described in a paper as yet unpublished. Mr. Roberts has not been able to trace any intluence either of forests or of the felling of large areas of wood on the maximum or minimum flows of the river (10).

As the results of observation are capable of varied interpretation, it is of interest to record that the influence of forests on stream-flow is now being experimentally studied (11). This important experiment, which will probably settle the question, was inaugurated in 1910 in the Rio Grande National Forest in the Rocky Mountains of Colorado. This experiment involves the careful measurement for a number of years of two streams flowing out of two well-wooded watersheds; and later a comparison of the flow of these streams after the forest cover has been removed from one of the watersheds. Dams, weirs, and recording instruments for measuring the flow of the streams have been installed, as well as instruments for measuring temperature, rainfall, evaporation, humidity, and other atmospheric factors that may affect the flow. All outside factors will be eliminated; and the records at the end of ten or twenty years are expected to throw much light on the relation of the forests on mountain watersheds to the flow of the mountain streams. 
The most important publication on the influence of forests on climate is a memoir of 197 pages, entitled Forest Influences, by E. B. Fernow and other writers, which was issued in 1893 as Bulletin No. 7 by the Forestry Division of the U.S. Department of Agriculture. The reader may also peruse with interest the paper (12), On the Thermal Infuence of Forests, read by Robert Louis Stevenson, the famous novelist, at Edinburgh in 1873. Stevenson suggested systematic observations at three sets of stations, in plantations, just outside them, and at a distance. Such researches (13) had, however, been begun in 1866 by Mathieu in the neighbourhood of Nancy, where observations at three stations were carried ont continuously till 1899. The German Meteorological Forest Service, which was established in 1875 , has made similar observations at various stations from that date onwards.

\section{NOTES}

1. In Proc. Amer. Soc. Civil Engineers, vol. 34, pp. 924-927 (1908).

2. Giandotti's monograph appeared originally in Giornale del Genio Civile, Rome, 1915 , pp. $325-408$ and 425.487 . It is divided into two prarts : (1) the influence of forests on climate in general and on precipitation, and (2) the influence of forests on the regulation of surface water and underground water. $\Lambda$ full aecount is given of the researches of Ototzky in Russia on the influence of forests on underground water. Floods in rivers, where the forests are preserved and where they are cleared, are discussed. A final section is devoted to Italy.

3. Isohyetal lines or isohyetals are lines drawn through and connecting places having equal amounts of rainfall.

4. In Internat. Bull. Agric. Intelligence, iii. p. 444 (1912).

5. See J. E. Church, in Engineering Reeord, 13th June 1914 and 17 th April 1915; Scientific American Supplement, 7th Sept. 1912, 1). 152 ; Sonderabdruek Hetcorol. Zeitsehr. xxx., 1913, Heft 1; Quarterly Journal R. Metcorological Socicty, xi. 43-55 (Jan. 1914); S. P. Ferguson in Science Conspectus, April 1913, pl. 152-157; Norman De W. Betts, in Proc. Soc. Ancr. Foresters, xi. 27-32 (1916); Journ. of Forestry, xvi. 585 (1918).

6. U.S. Geol. Survey, Water-Supply Paper, 234, p. 11 (1909).

7. Hall and Maxwell, U.S. Forest Service Cireular, 176, p. 11, and Proe. Soc. Aner. Foresters, iv. 133-150 (1909).

8. See Austin F. Hawes, "Influence of Forests on Water Storage and Stream-Flow," in Proc. Vermont Society of Engineers, 12th March 1914, p. 29 ; and Science, 21 st June 1912 , p. 959.

9. See Meteorological Office Circular, No. 6, p. 4 (Nov. 1916).

10. At the Annual Mecting of the British Waterworks Association at Birningham, 1918, Mr. C. H. Roberts said: "Reeords in Aberdeen went 
to show that forests had not reduced the river floods. Dry weather flows appeared to be higher than 100 years ago, when the forests were greater." See Timber Trades Journal, 19th October 1918, p. 503.

11. C. G. Bates, in Proc. Soc. Amer. Foresters, vi. pp. 52-63 (1911).

12. Proc. Royal Soc. Edinburgh, viii. pp. 114-125 (1875).

13. Huffel, Économie Forestiere, i. pl. 67-73 (1904). 


\section{CHAPTER II}

\section{THE SANITARY INFLUENCE OF FORESTS}

THE protection afforded by forests or even by belts of trees makes life more bearable in districts where cold and humid winds prevail. Crops are enabled to grow which would not otherwise succeed; and domestic animals enjoy vigorous health, fatten, and produce an increased supply of milk (1). Very few persons, not excepting scientific men interested in ecology, have recognised the full severity of the effect on all living things of humid winds conveying air at a low temperature and persisting for a long period of time. The effect of such winds on trees themselves is most marked. Their stems are greatly shortened in height, becoming under extreme conditions unable to rise above the ground, as is well seen on the west coast of Scandinavia, Denmark, Holstein, Scotland, and Ireland. It is not the cold alone of the mountain summits or of the Arctic plains that stops tree growth, but the combined effect of wind, wet, and cold.

In regions of extreme cold, if the air is still, there may occur large forests as in Siberia. Trees exposed to winds are not only lessened in height, but are also altered in shape, as they produce branches which grow best on the leeward side; and assuming what may be designated the 'flag' form, they indicate the direction of the prevailing wind, which may be determined by the feeble or absent growth on the windward side. The injuries to trees, which are commonly ascribed to salt spray (2), are probably due entirely to strong wind, as may be ascertained by examina- 
tion of the leaves. It is the force of the wind which, at the same time that it hurls the salt spindrift inland, damages the tissues of the trees (3). The favourable windbreak effect of screens of trees, or forests, is perhaps one of the best arguments for locating sanatoria for tuberculous patients in forest districts.

Dr. W. Gordon (4) proved that the strong prevailing westerly and south-westerly winds in Devonshire are harmful in phthisis, mainly owing to their chilling and depressing effect, though they tend in a lesser degree to excite bronchial catarrh in feeble persons. What I wish to emphasise is the invariable action of cold wet wind on plant and animal life in reducing vitality. To these winds are due the formation of peat on wind-exposed sites in localities with a high rainfall, as in the mountains of this country above a certain elevation. The further west, the greater the exposure to the wind and the higher the rainfall at low elevations; so that this kind of peat, known as mountain peat (5), is prevalent in the west of Ireland on land not much higher than 100 or 200 feet above sealevel, while in the east of Ireland, as in the Dublin mountains, peat scarcely occurs below 1000 feet altitude.

The advantage of forests and shelter belts to human beings, cattle, and crops in wind-swept districts must be admitted. In the western parts of Scotland and Ireland, and in Wales, the gardens of the gentry, which are surrounded with plantations and belts of trees, are remarkable for the luxuriance and variety of their shrubs, flowering plants, fruit trees, and vegetables, rivalling often the choicest gardens of the Riviera. Outside these sheltered grounds the neighbouring peasants in their exposed fields can never fatten cattle, and in some seasons lose by wind a great part of their corn crops. In the absence of protection from wind, they are unable to raise fruit like apples, which might be one of the most profitable industries in counties like Donegal, Galway, and Kerry. For profitable horticulture in these wind-swept districts, the provision of shelter by trees is essential. 
Shelter belts are of great economic importance, but this view of the subject scarcely comes within the scope of this book. I may advert to one or two points of interest. The utilisation of mountain pasture by sheep is a large industry. In the Highlands of Scotland extensive areas of the sheep farms are covered with bracken and are consequently of no value at present for grazing. Bracken land can always be covered with trees. It is believed that of the total acreage of mountain pasture in the Highlands, at least 10 to 20 per cent could be afforested without producing any reduction in the number of sheep, merely by planting up the bracken areas. Furthermore, the shelter provided would enable the grass to grow better and the sheep to thrive more, and would actually in the end increase the output of mutton considerably.

Throughout Ireland in the central plain and other lowlying districts, and in parts of Scotland, there are extensive tracts of peat, which were formed after the retreat of the Ice Sheet, by the gradual filling up of the shallow lakes that were due to the disturbance of the natural drainage by glacial deposits. The chilly effects of these peat-bogs is well known (6). They act as centres of cold, often giving rise to severe spring frosts in the adjoining farm land, so that early kinds of potatoes cannot be grown, while grass is later in spring in the pasture fields. In order to mitigate these effects, peat-bogs should be surrounded with plantations which can be easily and cheaply established in the cutover margin of the bog. This part of the peat moss is either already drained or can be drained at a small expense; and on it spruce, maritime pine, Scots pine, and larch can be profitably grown (7).

It was formerly believed that the leaves of the trees, by their absorption of carbon dioxide from the atmosphere and their exhalation of oxygen, made the air in a forest healthier; but Ebermayer showed that the oxygen exhalation of a forest in proportion to the needs of human respiration is insignificant, and is perhaps offset by the increase of carbon dioxide which results from the decomposition of organic 
matter in the floor of the forest (8). The occurrence of ozone in the air of forests, of mountains, and of seaside places, and its absence from the air of streets in towns and of inhabited houses, has given rise to the idea that this gas has some health-giving properties. It may purify the air by oxidising animal or vegetable matter in the course of decay and by uniting with the gases produced by their decomposition; but the minute quantity of ozone found in the air of forests can have little effect of this kind, and is evidently of no hygienic importance. Recent experiments have shown that ozone is useless as a disinfectant, since the quantity necessary to kill pathogenic bacteria is very irritating to the lungs and proves fatal to animals experimented on. Hydrogen peroxide also exists in minute quantities in the air of forests; but there is considerable difficulty in distinguishing by its effects this substance from ozone.

Forests depress the level of the underground water; and drainage can often be done effectually by planting trees. Diseases like phthisis, bronchitis, rheumatism, neuralgia, might then be diminished in forest areas. In damp marshy soils, pools are common, and serve as breeding grounds for mosquitoes. The planting of Eucalyptus trees in the Campagna Romana diminished malaria undoubtedly, by the permanent lowering of the subsoil water, which dried up the pools that bred the mosquitoes. The rôle of the forest in draining marshy places, where water stagnates for some months of the year, is not doubted by the French, who have seen this effect in the pine forests of the Landes and Sologne. In the forest of Mondon near Nancy the level of the underground water is throughout the year at least 12 inches lower than in the cultivated land adjoining, to cite only one of the extensive series of observations that were carried out by Prof. E. Henry of the Nancy School of Forestry. Similar results have been established by Ototzky in the forests of the steppes of Voronej province in Southern Russia.

The most important hygienic asset of the forest is the purity of the air therein. Smoke, particles of dust, injurious 


\section{THE SANITARY INFLUENCE OF FORESTS 17}

gases, and bacteria, which are all found in the air of cities, are rare or completely absent in that of forests. Microorganisms are carried into the air from ordinary soils, when their upper layers are dried and dust is formed, which is easily moved by the wind. In the forest there is less movement of air, and fewer microbes in the atmosphere, as was verified by the observers Serafini and Arata, who found all kinds of bacteria less numerous in the forest air than on its outskirts, generally 23 to 28 times less. The foliage of the trees acts as a kind of filter, and retains the dust and other particles which are contained in the air that passes over a forest or belt of trees.

Apparently no experiments have been carried out with respect to ionisation, dust, and nuclei in the air over forests. Prof. A. S. Fve in a letter says: "The factor which differentiates pure bracing air from relaxing air remains obscure. No doubt the absence of dust and nuclei is a factor, but there are probably other causes. Air wlich is well cleaned by rain or snow, with all the water present as vapour, and not as fog or mist, is bracing. Scots pine woods in Surrey are better than mixed woods in, say, Bedfordshire. In many cases the air passes from one state to the other in a few hours. What are the changes which take place?"

With regard to the soil of the forest, Ebermayer showed that it contains less albuminoid matter and salts suitable for bacterial growth, and that the humus produced by the growth of trees is antagonistic to pathogenic bacteria, which have not been found up to the present time in the soil of forests. Both the soil and the air of forests may then be looked upon as pure from the point of view of health.

It is stated that in India villages surrounded by forests are never visited by cholera; and troops are removed to forest stations to arrest the disease. Huffel (9) confirms this by the statement that the town of Haguenau in Alsace, which is encircled by a magnificent forest nearly 50,000 acres in extent, was always free from the epidemics of cholera which in the last century attacked several times the other towns in the same district. The classic example 
of improvement in public health due to forest conditions is that of the Landes in Gascony. This was formerly a bare sandy tract, interspersed with marshes, and reputed to be the most unhealthy region in France, the inlabitants being very subject to malarial fever, scrofula, and pellagra. Since about 1850 the greater part of the Landes, some 1,800,000 acres, has been afforested with maritime pine; and these diseases have practically disappeared, and the district is now one of the healthiest in France, the decrease in the death-rate being remarkable. This improvement in health is no doubt due to various causes, such as the drainage of the marshes, the better supply of drinking water, etc., but the presence of the pine forest must be recognised as a factor which has contributed to the sanitation. Even the abundance of cheap firewood has a hygienic effect, as every house is now free from damp all the year round, and the labourers are able to dry their wet clothes.

Parks in cities are like the forests. They do not purify the air, as was formerly believed, by the functions of the leaves. Nevertheless, the air in parks is purer than in the dust-laden atmosphere of the streets adjoining, and contains fewer bacteria. Belts of trees act as screens, and intercept dust and other impurities coming from outside; and it is of some importance on this account to make a wall of trees around any park or large open space in a city.

In the preceding pages the direct effects of the forest condition upon hygiene are briefly described; but there are many ways in which the presence of woods and trees affect indirectly the health of the public, and these will be discussed in the subsequent chapters. A great deal might be said in praise of the aesthetic value of forests and trees, which influence favourably the spirits and consequently the health of the people; but a mere mention of this aspect of the subject is sufficient. Few will deny its importance.

\section{NOTES}

1. Frank B: Kellogg, in Proe. Soc. Amer. Foresters, x. 51 (1915), says it is well known among dairymen having ranches in Oregon much exposed to 
the north-west wind that the milk flow is decreased on windy days. A large dairy owner north of Smith River, who weighs each day the amount of milk produced by his herd, states that in spring and summer the amount of nilk falls off as much as 16 per cent during the windiest days when the cattle are pastured on exposed fields.

2. Don and Chisholm, Modern Methods of Water Purification, p. 278, give a map showing the way in which salt is carried inland in the west of Scotland. See also W. Barr, in Journal of Hygiene, xiv. 119 (1914), on the laws regulating the blowing inland of salt spray and spindrift.

3. Observations were made by L. $\Lambda$. Boodle of the Jodrell Laboratory, Kew, on the foliage of seven species of trees and shrubs injured at Llanishen in Wales, five miles inland from the sea, by a severe gale accompanied by salt spray. Examination showed that the leaves of all the species, whether injured or uninjured, contained much more sodiun chloride (common salt) than the foliage of the same species growing in Kew Gardens. Injured and unliarmed parts contained the same amount of salt. This is taken up by plants from the soil, which in districts close to the sea and for some miles inland contains nuch sodium chloride brought by gales. The distribution of the brown discoloration on the leaves indicated wind-withering, due to loss of water, and did not seem to be due in any way to the direct eflect of salt spray. Cupressus macrocarpa and Euonymus japonica were unharmed, whilst Thuya, yew, Lawson cypress, common laurel, and Portugal laurel were all injured. See Gardeners' Chronicle, 26th Feb. 1916, p. 119.

4. See British Medical Journal, 12th Jan. 1901, p. 69, 23rd May 1903, 1). 1189, 4th Jan. 1905, p. 62, and 3rd Nov. 1906, p. 1165, and The Lancet, 7 th and 14 th Jan. 1905 .

5. The mountain peat probably did not begin to form till late in the Bronze Age. In the Neolithic period the temperature seems to have been $4^{\circ} \mathrm{F}$. higher than now, and the British Isles enjoyed a eontinental climate with prevailing cold dry winds from the north-east. After this, some time during the Bronze Age, the climate altered, and has gradually become wetter with prevailing westerly winds. Plunkett, in Kilkenny Journal of Archaeology, xiii. 537 (1875), states that the cairns, pillar stones, and stone circles on Topped Mountain in Fernanagh, which he dates as 1600 B.C., were built on the original rock surface, and since then have been covered with peat of the thickness of eight feet. He concludes that in the cairn-building time the climate was much warmer and less humid than now. The cairns on the Dublin Mlountains are also covered with peat. The existence of the optimum climate in the Neolitlic Period and early Bronze Age has been proved in other ways.

6. See Geo. B. Rigg, in Bot. Gazette, lxi. 159 (1916), where comparative tables are given of air and soil temperatures of peat-bogs and of arable land adjoining.

7. See A. Henry, " $\Lambda$ fforestation of Peat-Bogs and Sand-Dunes," in Country Life, 22nd April 1916, p. 497. This article contains an accomt of a cheap method of establishing maritime pine by sowing seed on cut-over bog at Abbeyleix. It was republished, without the illustrations, in a book by $\mathrm{P}$. Anderson Graham, Reclaiming the Waste, pp. 118-127 (1916).

8. See Fernow, U.S. Forestry Bulletin, No. 7, p. 170 (1893), and Economics of Forestry, p. 77 (1902).

9. Economie Forestière, i. 199, note (1904). 


\section{CHAPTER III}

\section{FORESTS AS SITES FOR SANATORIA}

As stated above, Ebermayer showed that forest air, like that of the seas and mountains, is free from injurious gases, dust, particles, and bacteria. The forest soil is hygienically pure. These facts are excellent reasons for locating sanatoria for tuberculous patients and convalescent homes in forest districts (Fig. 1). Such patients require open-air treatment, which necessitates protection against cold or severe wind. Wind raises dust, which increases cough and dyspnoea if the lungs are affected (1). The progress of patients is often best in mountain resorts in winter, when the snow lying on the ground prevents dust. Even when forests are not accessible, the occurrence of belts of trees around the grounds of sanatoria are useful for protection against wind. Walks in a wooded country are most agreeable, and the psychic effect of beautiful woodland scenery is beneficial in many cases of illness. As hay fever is due to a peculiar poison in the pollen of certain grasses and closely allied plants, places where these plants are rare or absent, like pine forests and heaths, may be resorted to with advantage by patients suffering from this distressing malady (2).

It has been the universal belief, from ancient times till now, that forests of conifers exercise a beneficial and curative effect on consumptive patients. The physicians of Rome, in the time of the Caesars, sent patients with ulcerated lungs to the pine forests of Libya. Pliny (3), in a statement that sounds quite modern, remarks: "Forests, especially 


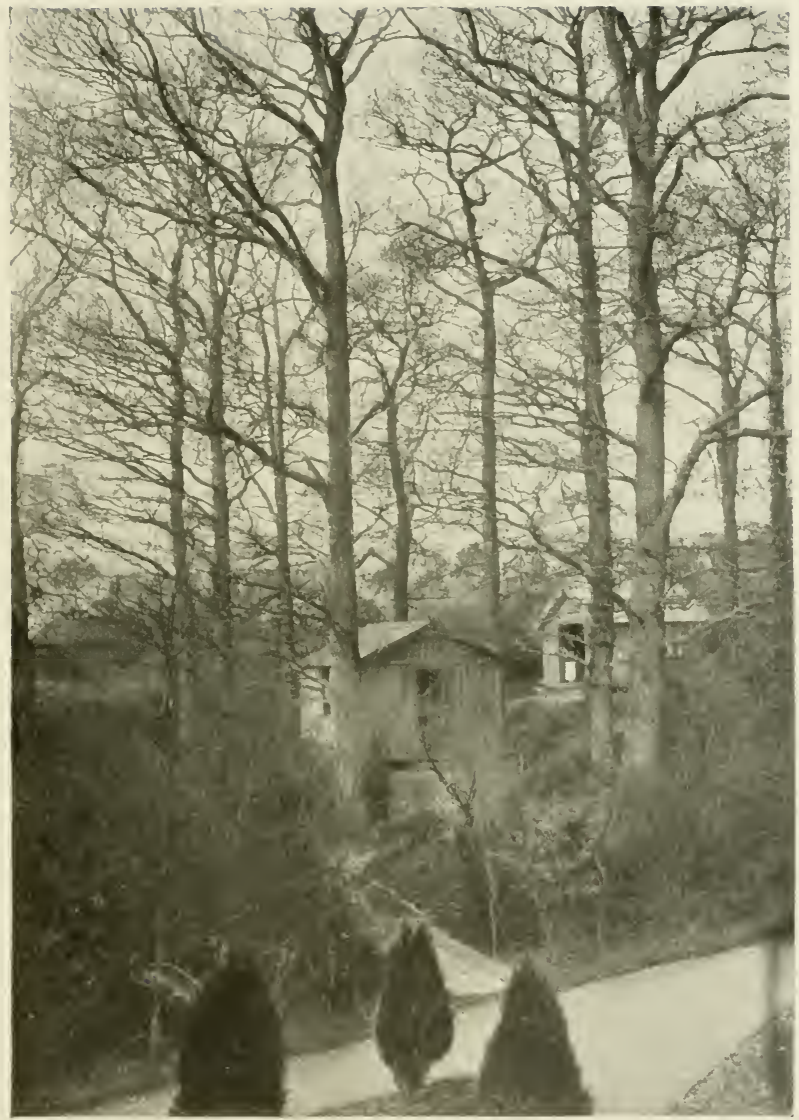

F11: 1. Sherping Chalets in Wuol at Linford Sinatorim, New Forest.

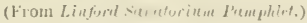




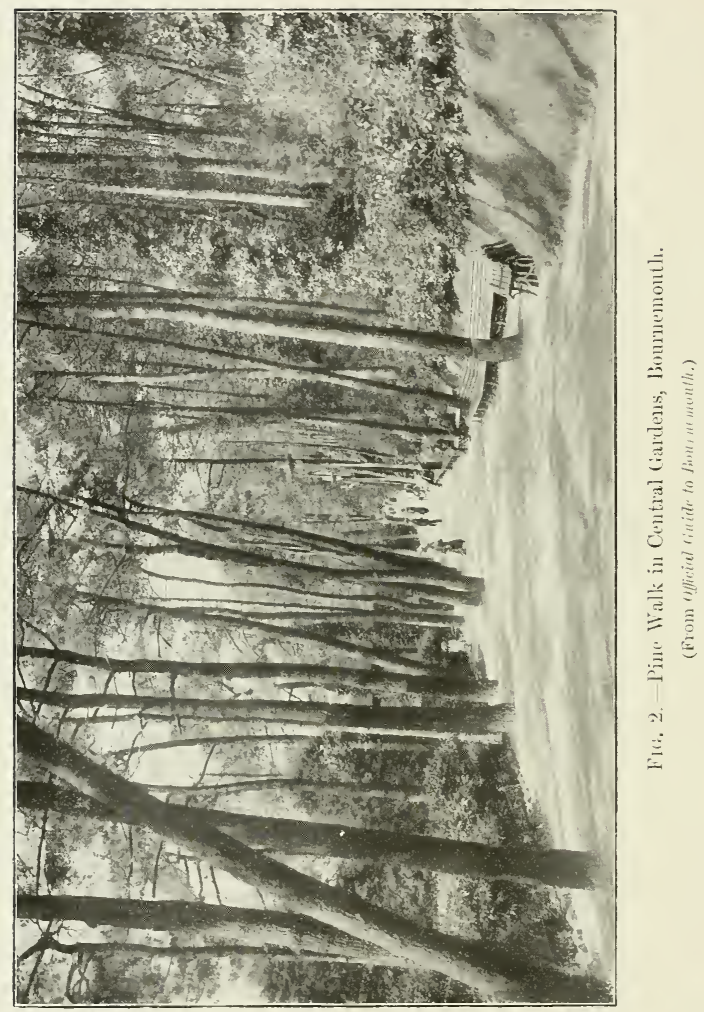


those which abound in pitch and balsam, are most beneficial to consumptives or to those who do not gather strength after a long illness; and they are of more value than a voyage to Egypt." Most of the descriptions in text-books (4) of sanatoria on the continent, and even in the British Isles, lay stress on the woodland or forest nature of the situation. In the United States Dr. A. L. Loomis of New York was one of the first to send tuberculous patients systematically to the Adirondack Forest, that they might have the benefit of the purest and most invigorating air (5).

The main features of the open-air treatment of phthisis, perhaps insisted on earliest by Dr. Geo. Bodington of Sutton Coldfield, Warwickshire, in 1840 , and by Dr. Henry MacCormac of Belfast in 1856, were first systematised at the Nordrach Colonie Sanatorium, which, founded originally by Dr. Walther, was acquired by the Baden Insurance Company in 1908. "It is a hamlet, not an institution, in a sheltered valley surrounded by pine-clad heights in the midst of the Black Forest." The Nordrach treatment consists in an absolutely open-air life, day and night, and in sunshine, fog, and rain; abundant diet; rest before meals; and exercise regulated by the bodily temperature. Graduated labour, at ordinary kinds of outdoor work, seems to be the best form of exercise (6), and has been introduced at the Brompton Hospital Sanatorium at Frimley. In pine forests these conditions are readily satisfied, as patients get pure air and an attractive milieu for exercise, while useful and interesting forestry work can be carried on in the winter. Intense cold, fogs, etc., do not interfere with the open-air treatment; but this could not be carried on without danger in windy places.

Walther believed in the paramount importance of purity of air, and associated with it paucity of population, which is the rule in forest districts. Where pine trees abound, the soil is usually dry and is often sandy. A treeless site is a great disadvantage for a sanatorium; but the trees must not be crowded around the building so as to interfere with ventilation. 
There now appears to be a reaction against the supposed beneficial effect of pine forests, based, I suppose, on Prof. Leonard Hill's campaign for unlimited movement of the air (7). It will be best for me to give some extracts from letters received from medical superintendents of noted sanatoria.

Dr. David Lawson tells me that "Dr. Walther advertised the merits of the situation of the Nordrach Sanatorium in a pine district, where the terebene vapours, exuded more particularly in the spring months, added a special value to treatment obtained there, as contrasted with that available at Falkenstein and other rival institutions which were not located in pine forests. In the early days of founding sanatoria in this country we accepted without examination the claims made for the specific benefits of treatment in pine districts. Personally I made a point of it to such an extent that I selected a pine wood in which to build Nordrach-on-Dee, Banchory. Whether the elaim is right or wrong I cannot now say. I am perfectly convinced, however, that a sanatorium (8) ought to be in its immediate vicinity surrounded by trees to provide shelter from strong winds in winter which are injurious to the less robust patients. Pine forests for the most part are located in healthy districts, far removed from large centres of population, and are therefore usually associated with those genial atmospheric conditions which undoubtedly have a very high value in the open-air treatment of phthisis."

Dr. W. O. Meek, of the Brompton Hospital Sanatorium at Frimley, says: "At one time the presence of Scots fir trees was considered of value on account of the exhalations of turpentine, etc. I think this idea is now almost obsolete. Scots firs seem to grow on elevated gravelly soils which are very suitable for sanatoria; and they are also very valuable as a shelter from wind and rain both winter and summer."

Both these experienced men believe in the value of pine woods as shelter; let us hear the other side. Dr. F. Kincaid Etlinger, Medical Superintendent of the Pinewood Sanatorium, Wokingham, writes to me: "When I came here, 
nearly four years ago, the estate of some 80 acres was densely covered with pines, growing close up to the buildings on all sides. As a result, the atmosphere was gloomy and depressing, and the ground immediately surrounding the sanatorium was cold and damp, being too well sheltered from wind and sun. The results of treatment in the sanatorium were not good, and there was a remarkable prevalence of a special symptom, namely, hemorrhage from the lungs. After discussion with Prof. Leonard Hill, I concluded that it was necessary for the welfare of the patients that the grounds surrounding the sanatorium should be heroically cleared of trees to as great a distance as possible. This has been done. The estate is now largely open ground, and many acres of pinewoods on the surrounding estates have also been cleared. The resulting improvement is quite definite. Sun and wind have freer access to the sanatorium. The general atmosphere has been greatly altered, and the ground immediately surrounding the buildings is drier and warmer. The results of treatment are much more satisfactory, and the incidence of the special symptom referred to above has decreased to a striking extent, and is no longer the serious matter which it was during the earlier days of the sanatorium." Dr. Etlinger is of opinion that there is no evidence that pine trees per se have any curative effect on consumption; and that the value of pines in the cure of phthisis depends on the fact that they are the only trees which provide shelter at high altitudes; but that "low altitude may be quite satisfactory, provided that the country for many miles around is equally low or lower and very barren of trees."

Dr. Etlinger believes with Prof. Leonard Hill that the rationale of the open-air life in the treatment of consumption lies in the improvement which takes place in general health owing to constant exposure to moving air rather than to fresh air. Prof. Leonard Hill is opposed to the growing of trees and close shrubberies at all near buildings.

Dr. Horace Dobell, who was in practice for many years at Bournemouth, believed strongly in the curative effect on 
pulmonary diseases of the pine plantations, which are so extensive in and around this famous health resort (Fig. 2). In his book on The Medical Aspect of Bournemouth, published in 1886, he devotes a chapter to this subject. He recognised the useful effect of trees as the best form of shelter from wind, being much superior to walls, banks, and rocks for that purpose, owing to the absence of the back wind which ricochets from these obstructions, and is often more destructive than the direct wind. Moreover, trees admit free circulation of air. He considered, however, that the main hygienic value of pines was due to the emanations from their leaves, which caused the atmosphere of a pine forest to have decided antiseptic and disinfectant properties.

Dr. A. D. Edwards, Medical Officer of Health, Bournemouth, thinks that emanations from the pine trees largely planted there "have a cleansing effect on the atmosphere, and also have a sedative effect on the respiratory mucous membrane. It is doubtful whether the emanations have any effect on the actual germs, as the proportion of turpentine in the atmosphere would be too small to have any effect."

I have been unable to find any statistics to show the incidence of tuberculosis in pine districts ; and such statistics would be valueless, as there are so many other factors involved, such as ventilation and size of the bedrooms used by the inhabitants in such districts.

It is needless to enter into a defence of the beneficial effects of the shelter afforded by forests and plantations. In the country, whatever may be the case in large towns, the stagnation of the air so ardently combated by Prof. Leonard Hill does not exist, except in low-lying and often badly drained depressions, where no one would locate a sanatorium. There is no fear of stagnation of air in the British Isles, even if the proper share of forests was established. The question, however, remains, what are the emanations of pine forests, and what effect have they, if any, on phthisis? A statement that " the balsamic emana- 
tions are so dilute that their effect is more psychical than physical " is not scientific.

Most people write of the turpentine emanations of pine forests, but the large amount of resin and turpentine stored in the wood and bark of the stems and branches is not exhaled into the atmosphere, except in the case of wounds or disease of the trees, which cause a flow of resin. The odour of pine woods is due, in great measure, to a volatile oil contained in the leaves. This is variable in composition, containing pinene (the main or often sole constituent of turpentine oil), sylvestrene, phellandrene, and a notable percentage of bornyl acetate, which gives to it a characteristic odour. Pine-needle oil, produced by distillation, is a clear odourless fluid used as a deodorant in baths, hospitals, etc., and is sold all over the world for rheumatic complaints (9).

No scientific study of the odours of the air from a therapeutic point of view has, I believe, ever been attempted. We are, moreover, quite in the dark as to the curative effect of change of air in many cases of illness, which is in our ignorance ascribed to psychic causes.

Two suggestions have been made in explanation of the curative effects of the odours of pines on tubercular diseases of the lungs. Dr. Horace Dobell relied on Kingzett's experiments (10) on the oxidation of volatile oils under the influence of air and moisture, when peroxide of hydrogen and camphoric acid were produced, the former being a powerful disinfectant and the latter an antiseptic. The volatile oil exhaled by pines being converted into these agents was supposed to render the atmosphere destructive to bacteria. No such germicidal action of the air in pine forests has, however, been proved to take place; and Dr. Dobell's theory is no longer tenable.

The researches in phagocytosis carried on by Prof. Hamburger (11) of Gröningen University, Holland, possibly afford an explanation of the therapeutic effects of the odours of pine forests. He exposes on slides under the microscope drops of blood which have been put into various 
media containing minute particles of carbon. Turpentine and allied substances, used in minute quantities as media, greatly increase the number of carbon particles that are swallowed by the leucocytes. In a dilution of $1: 100,000$ an increase was found of $24 \cdot 7$ per cent. In the presence of turpentine the percentage of the white cells that have taken in carbon is greater than in the case where no turpentine is added. This explains the remedial action of a subcutaneous injection of turpentine in the treatment of pneumonia in horses, as minute quantities of the turpentine, dissolving in the lymph of the tissue spaces and afterwards entering the blood circulation, promote the phagocytic power of the white corpuscles in the lung.

Hamburger says that the cause of the remarkable influence of a sojourn in high mountain regions on metabolism, on sleep, and on the state of the mind is entirely unknown. It has been proved that these phenomena are not due to the altitude as such, for in balloons they do not occur, nor are they found in all mountain regions, but only in those parts with coniferous woods. He thinks that it is due to the stimulating action of the odour of resin, turpentine, etc., on the nerve cells. The exhalations of the trees reach the lungs by inspiration, and are transported by the blood current through the whole body, and in consequence to the nerve cells, thus promoting metabolism, sleep, etc. May not such vapours, however, brought directly into contact with the white blood corpuscles in the lungs by every breath taken in, stimulate these to vigorous attacks on the tuberculosis bacteria?

It is probable then that Pliny was right in his view of the curative influence of pine forests; but at the same time we must not forget the injurious effect of screens of trees and shrubs close to a dwelling in blocking out sunshine and in stagnating the air.

As forestry work, varied in character and in muscular effort, can be carried on out-of-doors in all seasons, it is now utilised in the sanatorium treatment of consumptive patients. This is one of the features of the interesting afforestation 
scheme (12) devised by the authorities of Mid-Lanark for their water catchment area at Camps, in conjunction with the formation of a large permanent nursery at Hairmyres. This scheme will serve many useful purposes, some of which are novel. The Middle Ward of Lanark District Committee have established what is known as the Hairmyres Colony for the treatment of tuberculosis. Experience has shown that treatment in an ordinary sanatorium for a few months gives disappointing results in a large percentage of cases. The colony system provides along economic lines for an extension of treatment to patients who are liable to relapse on return to their former unhealthy environment. The Hairmyres Colony embraces an area of about 200 acres, and includes several working industries, with a competent head to give instruction in each department. The colony was founded to admit two classes of patients, namely, children and selected adult cases who have shown such improvement in other sanatoria that a further treatment of a special character is desirable. This includes special training in work on the land, market gardening, the rearing of pigs and poultry, and the early stages of forestry. Children work in the Forest Nursery for two hours daily in suitable weather, and adult patients do a full day's work.

The practical training in forestry embraces all branches of nursery work, such as raising forest trees, shrubs, and ornamental plants in Hairmyres nursery, and felling and conversion of timber on the Hairmyres estate during the winter months. On certain parts of the estate, planting trees on peat and underplanting of old plantations are carried out, operations which are valuable from the point of view of training men in forestry. Lecture courses at Hairmyres are arranged in connection with the Forestry Department of the West of Scotland Agricultural College, Glasgow. When the scheme is in full working order, convalescent tuberculous patients no longer requiring close medical supervision will be transferred from the Hairmyres Colony to the Camps area. Up to June 1918 only two have been sent. Both were notified cases of tuberculosis 
that had been under treatment for about a year. They did so well at Camps that when they reported for military service they were accepted and are now in the army. The high altitude of Camps is suitable for cases of tuberculosis that have passed the acute stage and those with catarrhal complications.

It will thus be seen that the scheme admirably fills two functions. It provides the proper kind of employment that aids in the cure of tuberculous patients; and it forms a practical training centre for such patients as intend making forestry their avocation in the future. Another useful and patriotic work embraced in the scheme is the teaching and employment in forestry work of disabled soldiers, who, when their training is completed at Camps, will be placed on estates in different parts of the country, through the cooperation of the Royal Scottish Arboricultural Society.

At present (May 1918) the nursery at Hairmyres, which was started in October 1913 , is about 12 acres in extent. In addition there is a demonstration wood and planting ground attached, amounting to some 20 acres. About 15 students from the West of Scotland Agricultural College in Glasgow, 6 discharged soldiers who are being trained in forestry, and 20 to 25 child patients are engaged in nursery work. In addition to the above, a four-weeks' training course in forestry for women is being conducted; and 40 trained women, who have passed through this course, have been sent out to various estates. These women are selected by the Ministry of Labour; and, in addition to nursery work, they are taken to felling areas in the vicinity, where they are trained in all branches of timber work.

Dr. Macpherson, the Superintendent Physician, states that the Forestry Department at Hairmyres is especially useful in providing different grades of labour for convalescent tuberculous patients. It is also a most suitable occupation for patients convalescent from neurasthenia, whether due to shell-shock or other causes, or for the soldier who has been gassed. Both patients and ordinary workers derive much 
improvement in health from forestry work. It is valuable as a sedative in excitable cases, and as a stimulant to respiration and circulation in those convalescent from acute and chronic illnesses.

All this special work at Hairmyres and on the Camps water catchment area will not of course interfere with the main objects of the scheme, which is defined as "the conservation and maintenance of the purity of the water supply." The afforestation will have as another object the production of timber suitable for the extensive local markets in the Lanarkshire coal-fields and the city of Glasgow. The working plan provides for this object with the minimum disturbance to sheep-grazing and shooting. No considerations, however, of sporting interests or of amenity will influence the forest policy, which is to produce the greatest net income from timber and wood.

The Camps water catchment area is situated in Crawford Parish, Lanarkshire, and has an extent of 6800 acres, comprising the gathering ground of the Camps and Grains streams. This area, with all rights, is the sole property of the County Council of Lanarkshire and of the District Committee of the Middle Ward of this county. It consists of an elevated tableland, at an average elevation of 1500 feet, composed of rounded hills covered with soil and grass or heather. The valleys are deeply cut down to levels of 800 or 900 feet in places. In the valleys erosion is taking place, including the brealing away of peat, thus tending to silt up the reservoir and render the water supply impure. Probably not more than one-third of the whole area will ever be afforested. It is proposed in no case to plant above the 1500 feet contour line, the considerable area above this line being permanently reserved for grazing and shooting. As soon as possible a belt of plantations will be established on the sides of the streams and reservoirs. Some land good for wintering sheep will be immediately taken up for planting; but when the scheme has been established, as soon as each block of wintering ground is enclosed, there will be a considerable block of forest thrown open to sheep. This 


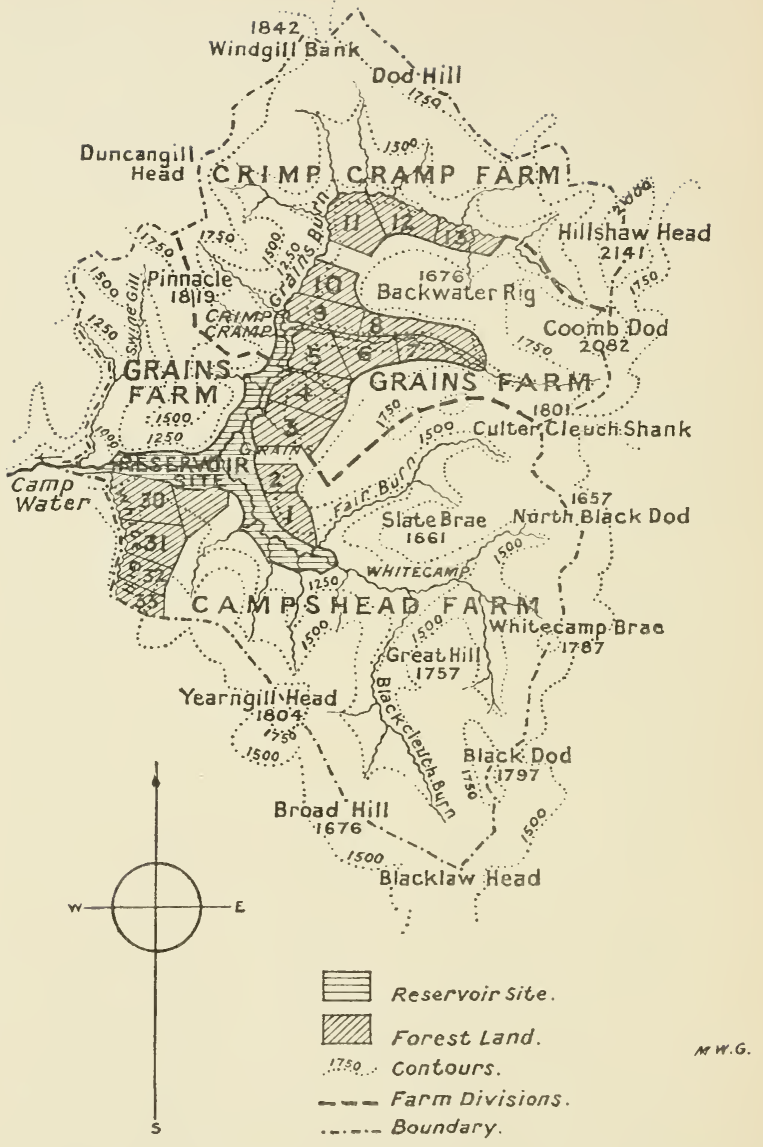

Lanarkshire.Sheet 16. _Scale, One Inchto a Statute Mile.

FIG. 3.-Mid-Lanark : Camps Catchment Area Afforestation Scheme. 
will have an enhanced wintering value on account of the shelter afforded by the plantations. The soil all over is of a good depth; and at elevations of 1400 feet a uniform depth of 18 to 24 inches is obtained. The land is used for grazing black-faced sheep entirely; and the natural herbage is heather and short hill grasses, with bracken in places. There are no woods on the area; but there are two plantations, both 55 years old, on adjacent similar land. The Campside wood of Scots pine, at 900 feet elevation, with a volume of 4000 cubic feet per acre, indicates third quality for this species; while the T'ee wood of spruce, at an elevation of 1200 feet, has a volume of 5360 cubic feet of timber and small wood per acre, indicating second-class site for spruce. These woods are not, however, fully stocked; and more timber would be grown under a proper system of sylviculture. As elsewhere, the fact is established that spruce is the timber-producing tree at high altitudes. This species mixed with silver fir will be the main crop. Larch and Douglas fir will be planted on selected sites. For the first five years the plan provides for 527 acres to be taken in hand and planted. These particulars show how much care has been taken in the drafting of the Camps Afforestation Scheme by - Mr. G. P. Gordon; and great praise is also due to the public spirit and large views of the Mid-Lanark District Committee.

Planting was begun on the Camps area in March 1914, and two nurseries have also been established. It the end of May 1918 the plantations amounted to 350 acres, and included 163 acres of spruce, 105 acres of larch, and 43 acres of Scots pine. All the planting was done by German prisoners.

In 1915-1916 the Development Commissioners recommended a loan of $£ \$ 962$ to the l)istrict Committee of the Middle Ward of the County of Lanark in aid of the afforestation of 1327 acres of the water catchment area at Camps. The Treasury, however, did not assent to this recommendation in view of the urgent necessity for conserving the resources of the country for war purposes; but sanctioned 
a loan of $£ 600$ in order to save the Committee from loss on the plants already purchased in connection with the scheme, and reserved for a later date consideration of the scheme as a whole.

\section{NOTES}

1. A. Haviland, quoted by Weber, Climatotherapy, p. 47, says : "Regions exposed to high winds have increased mortality from phthisis, as people stay indoors more and in stuffy rooms. High winds hurt feeble people and persons suffering from bronchial affections."

2. See Glegg, in Journal of Hygiene, 1904, pp. 369-403.

3. Hist. Nat. lib. xxiv. cap. 6.

4. See F. Rufenacht Waters, Sanatoria for the Tuberculous (1913); Weber, Climatothcrapy; Wood, Health Resorts, etc.

5. See Dr. Guy Hinsdale, Atmospheric Air in relation to Tuberculosis, p. 3 (Smithsonian Institntion, Washington, 1914). This book is an admirable résumé of the subject, beautifully illustrated.

6. The scientific basis of this treatment is set forth by Dr. A. C. Inman, On the Effcct of Exercise on the Opsonic Index of Patients suffering from Pulmonary Tuberculosis; a study made possible by the brilliant work of Sir Almroth Wright, who showed that nature cures bacterial infections through auto-inoculation.

7. See Local Government Reports, New Series, No. 100 ; Report on Ventilation and Effect of Open Air and Wind, by Leonard Hill (1914).

8. In the Nordrach-on-Dee Sanatorium booklet, the advantages of the site in a pine forest are insisted upon. The Deeside atmosphere is claimed to possess relative dryness, bracing qualities, and exceeding richness in ozone. The other advantages are: "its comparatively mild temperature during the winter months; the high percentage of sunshine which prevails; and the therapentic vapours exhaled by the pine forests."

9. See S. J. Record, in Scientific American, 22nd January 1916, p. 200. French turpentine oil is almost entirely laevopinene, and American turpentine oil nearly all dextropinene.

10. Kingzett, Nature's Hygiene, pp. 185.188 (1880).

11. See British Medical Journal, 8th Jan. 1916, p. 37, and Proc. Royal Society of Netherlands, xvi. 609 (1913).

12. See Mr. G. P. Gordon's account of the scheme in Trans. Roy. Scot. Arbor. Soc. xxix. pp. 55-62 (1915). I am indebted to Mr. Gordon for a copy of the Working Plan of Camps Area and Hairmyres Nursery, as well as for many beautiful photographs and lantern slides illustrating the splendid work, in the inauguration and carrying out of which he has taken a large part. 


\section{CHAPTER IV}

\section{PARKS IN TOWNS AND MUNICIPAL FORESTS}

THE real history of public parks in towns begins about 1840. Before that time there were no municipal parks, except perhaps Glasgow Green. The parks of London were originally the private property of the Crown, and, besides, were in early days not open spaces preserved in the city, but were far away from it in the country. St. James Park, Green Park, Hyde Park, and Kensington Gardens were at a considerable distance from the city of London. Even Glasgow College Green was originally outside the city. In $184 \tilde{j}$ the Health of Towns Commissioners made recommendations about public parks and open spaces, which laid the foundations of modern progress in this important measure of public hygiene. The Commissioners said: "In our enquiry into the sanitary condition of large cities and populous districts, where a high rate of mortality and much disease is prevalent, we have noticed the general want of any public walks, which might enable the middle and poorer classes to have the advantage of fresh air and exercise in their occasional hours of leisure. With regard to all open spaces, especially well-ordered squares ornamented by trees or gardens, which already exist in the metropolis and large towns, we strongly recommend their preservation from any encroachment by public or private buildings. Although not open to the public, they contribute largely to the general health of the people. The great towns of Liverpool, Manchester, 
Birmingham, Leeds, and many others have at present (1845) no public walks. Shrewsbury, Newcastle-underLyme, Derby, and few more possess them. The metropolis except at the west and north-west, where the different parks minister so much to the comfort and health of the people, has no public walks, thongh Victoria Park, now in progress, will supply the want to the east. The large populations of Southwark and Lambeth to the south are yet without such a source of enjoyment and salubrity. The Select Committee of the House of Commons in 1833 recommended that steps should be taken to supply the want. In 1840 the sum of $£ 40,000$ was voted by Parliament to assist local efforts for this purpose in provincial towns, and a few places have had grants from this sum."

The Commissioners in conclusion strongly recommended "that for the purpose of establishing public walks, in addition to legal facilities, the local administrative body be empowered to raise the necessary funds for the management and care of the walks when established."

Prof. James Thomson in a lecture (1) at Belfast on 2nd March 1852, "On Public Parks in Connection with Large Towns," said that Manchester then had three parks, though at the time of the Commissioners' report it had none, and Victoria Park in the east of London had just been opened. This lecture led to the purchase, for the town of Belfast, of the large Ormean Park.

Thomson pointed out that the rapid extension in the size of towns, while increasing the happiness of the rich, who escape to the outskirts, had entailed on the inhabitants new discomforts, of which the chief were smoky air and increased distance of their residences from the country. The establishment of public parks was a just claim on those who had been made rich by manufactures of towns. He advocated the laying of a tax on owners of vacant land near a town, as soon as it was first built on, the object of the tax being to supply funds for the establishment of permanent open spaces, as a compensation for the evil 
inflicted on towns by buildings erected on their outskirts. Inasmuch as proprietors obtained accession of value as the town spreads, through no exertion of their own, such a tax would be equitable. Thomson, however, being a practical man, did not desire people to stand idly by till such a tax was imposed, but to proceed by private subscriptions to acquire land for public parks, aided by public grants.

The creation and development of the numerous public parks and open spaces in Birmingham illustrate well the enlightened progress of a great municipality, since 1852 , "when there were no public walks in Birmingham." It will be seen how voluntary effort stimulated and brought into being the necessary municipal enterprise. The story of the Birmingham public parks is doubtless typical, and will stand for the history of this movement all over Great Britain.

It was not until 1851 that an Improvement Act gave the Corporation powers to acquire land for purposes of health and recreation. Adderley lark, the first public park of Birmingham, was laid out in 1856 on a plot of building land of abont 10 acres, which was a gift for this purpose to the Corporation by Mr. Adderley. Calthorpe Park, 31 acres in area, was opened in 1857; but the fee simple on the ground was not conveyed to the Corporation until 1894. Aston Park, now 49 acres in extent, first opened as a recreation ground by a private company in 1858 , was purchased for $£ 26,000$ in 1864 , the Corporation contributing to the price $£ 19,000$, and seventeen citizens

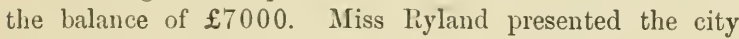
with Cannon Hill Park in 1873. It was then pasture land with fine old trees, and has since been abundantly planted with shrubs and trees, and enriched by an arboretum and beautiful gardens, one of which (Fig. 4) is set apart for the use of botanical students. The area, at first 57 acres, has been increased gradually to 73 acres. Highgate Park, 8 acres of waste land, was purchased by the Corporation for $£ 8000$ and opened in 1881. Summerfield Park, a well-wooded demesne, originally 12 acres in area, was also 
obtained by purchase. Opened in 1876, it has been extended to 34 acres, the total cost amounting to $£ 26,330$. Miss Ryland presented as a second gift to the Corporation 43 acres of partly wooded land at Small Heath, and $£ 4000$ to lay it out as a park, which was opened as Small Heath Park in 1879, and renamed Victoria Park in 1887 .

The most important event in the history of the parks of Birmingham was the securing for public use of the Lecky Hills, the only range within easy access of the city. A few building plots had been sold on one of these hills, Rednall Hill. Mr. Grosvenor Lee, the Secretary of the Birmingham Association for the Preservation of Open Spaces, in 1887, with the help of several prominent citizens, purchased the rest of the hill, 32 acres, which was conveyed to the Corporation in 1889 , as a place of public recreation for ever. The other two hills, Beacon Hill, 33 acres, and Bilberry Hill, 49 acres, were afterwards secured. Beacon Hill rises to 1000 feet elevation and commands a view of ten counties. The acquisition of this lilly tract, covered with pine and larch and heather, was a great achievement. The learned American blacksmith, Elihu Burritt, gives this description : “Any summer day in the year when the sun shines on them, these hills are set to the music of merry voices of boys and girls and older children who feel young on the purple heather at fifty."

of the parks in the added areas, not formerly included in the district under the control of the Birmingham Corporation, there may be mentioned Handsworth Park, 63 acres, at Handsworth; Queen's Park, 14 acres, at Harborne; and Sparhill Park, 19 acres, at Yardley, mostly acquired by purchase. In the well-wooded district of Warley, Lightwoods Park and its extension, some 30 acres, were the gift of several citizens from 1903 to 1915 . Warley Park, a fine natural woodland of 109 acres, was partly acquired by gift and partly by purchase, the cost to the Corporation being $£ 50,472$. Perry Park and Reservoir, about 100 acres, of which 88 acres was purchased for 
$£ 7095$, the rest being rented from the Water Department, constitutes an attractive park.

There are $2 \bar{j}$ parks under the control of the Corporation, with a total area of 876 acres. Besides the parks there are 36 recreation grounds, 532 acres in extent, and 19 open spaces with an area of 16 acres. Mr. W. H. Morter, the Superintendent of Parks, tells me that to each acre of land in the parks and open spaces of Birmingham there are 625 inhabitants.

In these parks and open spaces many innovations have been made. Concerts of good music and band playing are given; and in 1915 dancing in the open air was introduced with great success. Provision for organised games, whereby the children are taught how to play, was begun in 1912 at a cost of $£ 250$ to the Parks Committee, which was increased to $£ 564$ in 1914. The games are commenced on 1st May and last till the end of September in each year. In this movement, which has spread in the United States (2) with the most wonderful effects, Birmingham has been the pioneer in England. The poorer children in the slums, who knew nothing of the common games played by children in country districts, are now taught various games in most of the parks and recreation grounds. This service is rendered by elementary teachers carefully chosen for their personality and their enthusiasm for games. Mr. Norman Chamberlain reports a marked effect of these games in improving sportsmanship, manners, and cleanliness. Parents and friends attend in large numbers; and the children are drawn from the streets to the parks, with consequent improvement in their physical well-being. The play in the parks can be indulged in with greater freedom and less liability to accidents than that in the streets and waste grounds; and is carried on in more cheerful and health-giving surroundings.

The general policy of the Birmingham Parks Committee is worthy of imitation by similar bodies, and is summed up as follows by Mr. Norman Chamberlain:

1. To save on administration and decorative effects and to spend on new sites. 
2. To use method and foresight rather than to wait for public agitation at the last moment.

3. To secure the fullest use of the parks by catering to all tastes.

4. To trust the public as much as possible in the enjoyment of what is after all their own property.

To these counsels may be added others suggested by Mr. Basil Holmes, the Secretary of the Metropolitan Public Gardens Association (3). The most important is, in every city and town, to get voluntary Open Spaces Associations to work, who will exert contiumous pressure on the Corporatious in regard to the laying out of parks and open spaces. Such voluntary agencies can plan skilfully for the future, and see that land is acquired before it is built over. Corporations will often maintain what is handed over to them by the gifts or forethought of such associations or individual citizens.

The great advantage of the Town Planning Act is that an area, developed under a plan, will have parks and open spaces greater in amount and more evenly distributed than the haphazard systems of the past. Three zones should be clearly recognised in a town, in order to plan skilfully for its needs of parks and open spaces, namely, a central district, the more modern parts adjoining, and the suburbs.

Encroachments on public lands, burial grounds, and the like should be checked by the watchful care of the voluntary associations, and suitable parks should be suggested for acquisition by gift or purchase. Several large towns are still in need of parks and recreation grounds, and voluntary associations should be started in such places. Any house in a park acquired should be utilised for some public purpose, as library, museum, shelter, refreshment room, etc., and not be afterwards allocated for some special class of people, involving a portion of the open space being cut off to form a separate garden for the house. The whole of Golders Hill was secured for the public by private and public subscriptions; and it was with great difficulty afterwards that the London County Council was prevented from 
using the house and a large strip of adjoining ground as a permanent convalescent home. The free use of common lands is occasionally interfered with by letting portions for golf and other games. Much good work has been done by the Commons and Footpaths Preservation Society, which was founded, as a result of the report of the Committee of the House of Commons appointed in 1864 , to inquire into the best means of preserving the forests, commons, and open spaces in and near London for public use. Wimbledon Common, Hampstead Heath, Epping Forest, etc., which were in danger of being enclosed, have been kept for the people.

The Metropolitan Public Gardens Association, which was founded in 1883 by the Earl of Meath, has done much useful work in continuously drawing attention to the necessity of providing town dwellers with parks, gardens, and recreation grounds within easy reach of their homes. The Association has laid out numerons disused churchyards and burial grounds, enclosed squares, and waste places. These, accorling to circumstances, are either laid out as gardens, or as gardens and playgrounds combined, or as playgrounds pure and simple. The extent of this work is shown by the fact that from 1884 to 1912 the Association spent $£ 44,248$ in laying out 115 open spaces, and contributed $£ 9679$ to the acquisition or formation of 47 gardens, playing fields, etc. Before laying out each ground, the Association arranges for its permanent maintenance by securing its transfer to the London County Council or local authority, under the Open Spaces Acts, or by obtaining special grants from public bodies or private individuals. The Association plants trees in suitable thoroughfares, and gives advice in pruning which is greatly needed, owing to the way in which trees are often maltreated by unskilful pruning and lopping. It has promoted further legislation for giving public bodies all over the country increased powers for purchasing land for public recreation, as the Open Spaces Acts of 1887, 1890, and 1906, ete.

One of the questions (4) to be considered in town planning is what proportion of the area of a city should be 
set apart for its lungs and for recreation grounds. Good water supply and sewage, fewer people per house, and good ventilation have undoubtedly kept down the death-rate of large towns; but there is no means of determining exactly how much of this improvement may be due to the extension of parks and open spaces. The influence of parks, especially if the trees form real woodlands, and give children and tired workers pure air, must be considerable. The amount to be apportioned in a city, and how much of each park should be under trees, is as yet undecided (5). Mr. Holmes has secured returns from the fifty chief towns in the kingdom, showing that in 1883 they possessed in the aggregate one acre of parks and open spaces to 760 people; whereas 20 years later, in 1903 , notwithstanding an increase in population of 50 per cent, there was one acre of parks and recreation grounds to 635 people. In the County of London (6) there was in 1883 one acre of open space to 950 persons, whereas in 1910 there was one acre to 750 people. Birmingham in 1917 had one acre of parks and open spaces to 625 inhabitants.

Mr. Holmes condemns the ordinary school playground with its hard surface and high walls as being like a prison yard, and no wonder the children prefer the streets. He agrees with me that the best form of playground is a grove of trees, with a bare sandy surface beneath. The natural feature of the larger parks and commons should be carefully preserved; the less elaborate the treatment the better, as the public love areas over which they can wander at will, and are too often hindered in their games and exercise by enclosures, railings, and notices.

The National Trust for Places of Historic Interest and Natural Beauty has done admirable work since 1895 in acquiring for the enjoyment of the public many properties of interest. Some of these are woodland and of value in the wide sense to public health. The most interesting is perhaps Box Hill, 234 acres in extent, which was presented to the National Trust by Mr. Leopold Salomons in 1914. Others are Ide Hill, near Sevenoaks, 21 acres, purchased in 


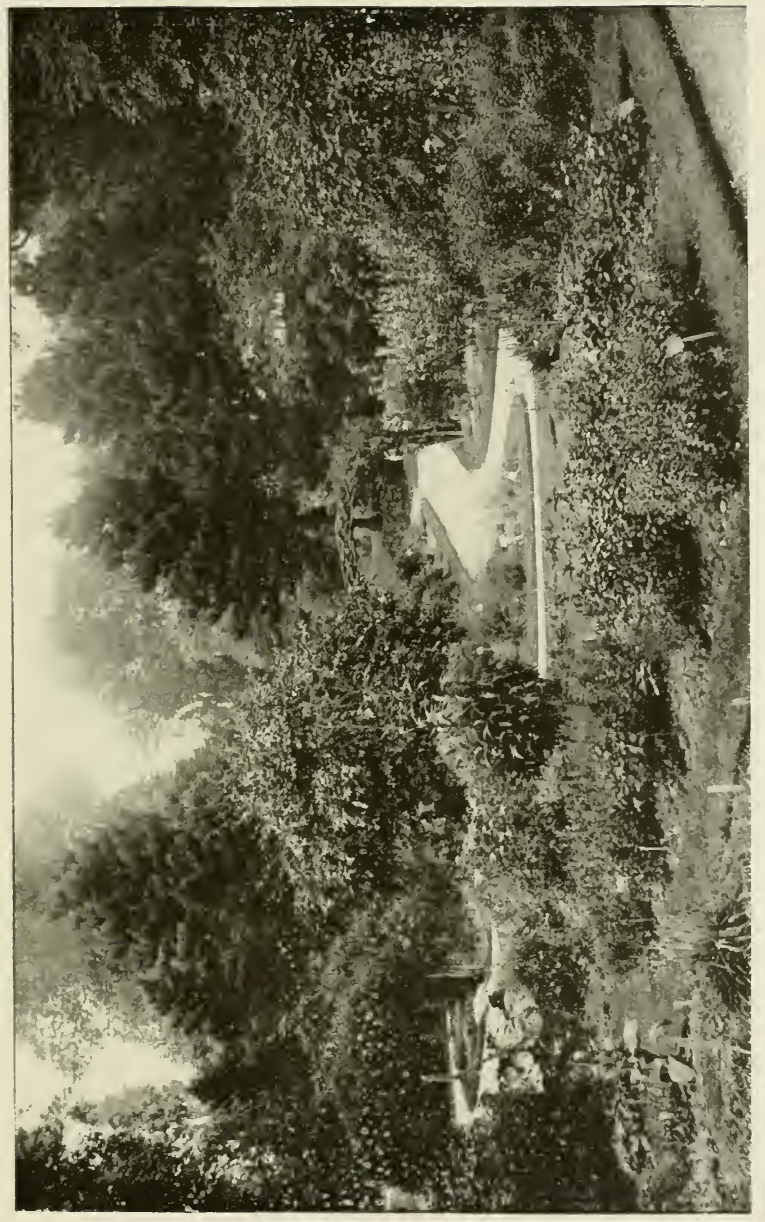




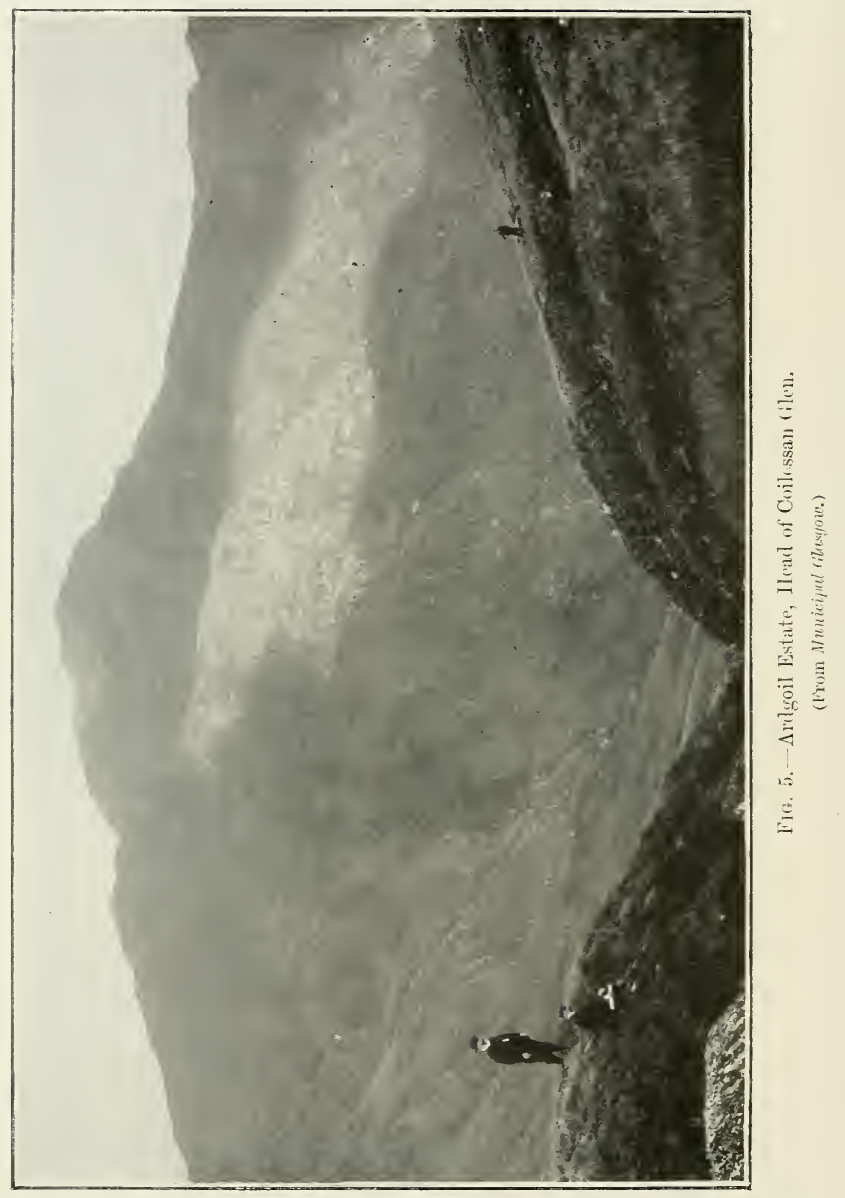


1899 and 1914; Manesty Wood, Derwentwater, 105 acres, purchased in 1902 and 1913 ; Leigh Woods, Bristol, about 80 acres, presented to the National Trust by Mr. George Wills; Hydon Heath, a tract of beautifully wooded land about 92 acres in extent, near Godalming, purchased in 1915 and dedicated to the memory of the late Miss Octavia Hill.

Glasgow, renowned for its municipal enterprise, is the first city to acquire a forest area for the recreation of its inhabitants. The estate of Ardgoil (Fig. 5), 14,740 acres, in the Highlands of Argyllshire, about 40 miles distant from the city, was presented to the Glasgow Corporation in 1906 by Mr. A. Cameron Corbett, now Lord Rowallan. It is situated between Loch Goil and Loch Long, and rises on Ben Donich to 2774 feet and on Ben Ime to 3318 feet elevation. A great deal of the land is over 1000 feet elevation, and none of this can be afforested. There are approximately about 4000 acres under 700 feet elevation, which could possibly be planted with trees. Some of this is covered with coppice and natural woods of oak and hazel, intermixed with ash, alder, and birch. It is proposed gradually to improve these areas by cutting away the existing poor woods in groups of one to five acres, then planting with fast growing and remunerative conifers like European and Japanese larch, common and Sitka spruce, Douglas fir, Scots pine, etc. (7). A nursery has been established, and by October 1918 about 500 acres had been planted with $1,000,000$ trees. The species mainly used were larch, Scots pine, and Douglas fir, and the plantations are now very flourishing. In the nursery there are about $1,000,000$ young trees which will be put out during the next four years (8).

By the deed of gift, due consideration must be given to the amenities of the Ardgoil Estate in any scheme of planting, as the greater part is free to public access. Mr. Whitton's plan of afforestation fulfils this condition and increases the amenities of the estate. In addition, the plan does something to help our National Timber Reserve, which 
is going to be created for supplies of timber in the distant future. In this region, moreover, certain timber trees grow fast, and surprising financial results have been obtained a few miles off at Gairletter, on Loch Long. In 1912 a plantation here of Douglas fir and Thuya, 35 years old, was blown down (9). The timber amounted in volume to 7430 cubic feet per acre, and was sold in the very accessible market of Glasgow for $£ 130$ per acre.

\section{NOTES}

1. Collected Papers by James Thomson, 464-472 (1912).

2. The organised Playground Movement in the United States is about 30 years old. In 1912, 332 cities were conducting organised play under qualified play leaders, and $25 \%$ cities and towns were spending $\$ 3,500,000$ a year on the maintenance of playgrounds. In all those cities, places are set apart where children can play under supervision, not mere school yards. The play leaders are as a rule better paid than the school teachers, and constitute a new and independent profession. At Chicago a Training School for playground workers, at which 17 subjects are taught, was opened in 1911. A Professor of Play was appointed at Pittsburgh University in 1910. The effects of the movement on the moral and physical health of the population are manifold and far-reaching. Tuberculosis is prevented by the pulling down of tenement houses for the erection of children's playgrounds in the congested areas. The effect of the organised play in increasing school discipline and efficiency is well marked. There is a notable decrease in school truancy and juvenile delinquency. The school curriculum has become widened and carried a little into the open air. Children's gardens and libraries founded by the playground associations have become school gardens and libraries. See Board of Education, Educational Pamphlet, No. 27 (1913): "The Playground Movement in America and its Relation to Public Education"; and City of Birmingliam Parks Department, Reports on Organised Games, 1912, 1913, and 1914.

3. I quote liere largely from papers furnished by the Metropolitan Public Gardens Association, including their Annual Reports, an article in Journ. Sanitary Inst. xxiv. 604 (1903), and a paper read at Bradford in 1903. The history of the movement is described fully by Mr. Basil Holmes in a paper entitled "Open Spaces, Gardens, and Recreation Gromnds," read before the Town Planning Conference, convened in London by the Royal Institute of British Architects in October 1910.

4. See Bazalgette, in Proc. 1nst. Civil Engineers, vol. 76, p. 2 (1884).

5. Though parks and gardens are a primary necessity for large towns, yet their good influence is felt in small towns as well. See G. T. Hunt, Borongh Surveyor of Dorchester, "On the Provision and Laying ont of Pleasure Grounds in Small Towns," in Journ. Sanitary Inst. xxi. p. 113 (1900).

6. Sir Gilbert Parker stated in 1910 that there is only one acre of open space to 15,000 people in Shoreditch, and one acre to 14,000 people in Southwark. 
PARKS IN TOWNS AND MUNICIPAL FORESTS 43

7. See Mr. James Whitton's Reports on the Ardqoil Estate to the Glasgow Corporation, dated 14th Oct. 1907, 24th Oct. 1912, and 15th Jan. 1913 ; and Address to the liotary Club, Glasgow, on 31st Oct. 1916.

8. See Timber Trules Journal, 28th September 1918, p. 395.

9. See Trans. Roy. Scot. Arbor. Soc. xxviii. p). 107 and 176 (1914). 


\section{CHAPTER V}

\section{TREES IN TOWNS}

IN foreign countries with a warmer climate than ours, like France, Italy, and the United States, trees are almost a necessity in the wider streets of towns on account of the shade which they provide in summer. They do away with the hot and dazzling pavements, which are not merely unpleasant but are highly dangerous to health. The New York Medical Society placed on record (1) their opinion "that one of the most effective means for mitigating the intense heat of the summer months and diminishing the death-rate among children is the cultivation of an adequate number of trees in the streets."

In the streets of our own towns the need to plant trees as a protection from injurious heat is not so imperative, and the arguments for the practice are mainly aesthetic. Trees add much to the beauty of a city. They soften the harshness of a row of bare houses. They have a restful effect, yet are intensely interesting in their variety, as they change from day to day and from season to season. In the winter we see their beautiful outlines formed by the tracery of their twigs, and admire their bark. In the summer they are varied in their foliage, which changes its tints often to magic colours in autumn. Trees are on the whole more suited for suburbs than for the central or business quarters of a town. They add greatly to the happiness of the inhabitants of mean streets. They have in this way a hygienic effect. 
Trees should never be planted in narrow streets, and can only safely be planted when the footpaths also are not narrow. It is objected to trees that they render the thoroughfare moist; but such moisture as they occasionally cause does no harm to the surface of the roads, and on the contrary keeps them in better condition than dry dust would do. Some people do not like the fallen leaves of trees, but the trouble of removal is very slight.

That towns are unhealthy to vegetation and especially to trees is well known; and this subject is relevant, as illustrating the strange fact when one thinks of it, that towns owing to various causes are unhealthy, just in the same way to human beings as they are to trees. First, there is the smoke of towns, which is a wicked waste of coal and entirely preventable. Evergreen trees in London are quickly coated over in winter with a dark shining carbonaceous product (2), soot, and need washing in the Botanic Garden of Regent's Park. The smoke of towns (3) causes the pores of the leaves to be blocked, thus checking transpiration. Every dirty plant is practically living in twilight, as the soot reduces the assimilation of carbon lioxide by the leaves, depriving them of their most important source of food. Last of all, the sulphur contained in ordinary coal when burned is changed into sulphur rlioxide, which ultimately forms sulphuric acid, a deadly corrosive poison to the leaves (4).

The soil under streets in towns is unfertile, and is often very poor, being composed of building debris, etc.; but its main defect is its dryness, as owing to the modern pavement all the water, which falls as rain, runs off into the sewers, finding its way into the sea, and never reaches the soil, where the roots of the trees are. Drought is the greatest enemy of trees, as the latter, owing to their extensive surface of foliage, require enormous quantities of water. The only trees that thrive in streets in towns are those able to resist drought.

The soil, according to Wieler, being made acid by the action of the sulphur compounds in the soot, loses its 
bacterial activity, and becomes unfertile. The addition of new soil is often favourable, as it inoculates the old soil. Chemical works in towns, which pour into the atmosphere fumes of hydrochloric, nitric, and sulphuric acids, are fatal to all trees within a certain radius. The new methods of oiling and tarring roads are probably injurious to trees; but this fact is not yet quite established (5). Trees are also killed in towns by the escape of ordinary lighting gas, if their roots are exposed to the leak for some time. Trees are also injured by the escape of electric currents. All these make a long list of evil conditions to which trees are subject in cities; and there is little doubt that fine trees in the centre of modern towns are decaying rapidly and disappearing. I still think that the great enemy is drought, want of water in the soil. To all these evils must be added the injury often done to trees when the level of a street is altered, when pipes are laid or changed, etc. In fact trees in towns are in constant danger from ignorant workmen.

In the central or business quarter of a city or town, where the ground is covered with buildings and pavements involving the worst conditions of soil, the species that have proved successful in the streets are very few in number. Thus, the list of desirable street trees in Paris comprises only eleven species, and in Washington twelve species. In England the choice is even more restricted. Prof. Farmer could recommend to the Kensington Town Council only four trees, namely, plane, Ailanthus, Jersey elm, and Lombardy poplar, though he suggested the trial of four others, namely, common lime, single-leaf ash, red-flowering horse-chestnut, and Bolle's poplar.

In the residential area or suburbs, where gardens or small plots often intervene between the houses and the pavement, the roots of the street trees find copious supplies of air and water at no great distance. The soil conditions are much more favourable than in the centre of the town, and the list of species that can be successfully planted is considerably augmented. In parks and open spaces, where the soil is in 
a natural state, numerous species may be grown, if the smoke nuisance is slight.

As regards planting in towns generally, the choice of trees should be restricted to really hardy species, which can live and thrive in the climate of the district, and which are capable of withstanding wind, if the situation is at all exposed. Species not liable to attacks of fungi and insects are also very desirable. The difference in the climatic requirements of trees is much greater than is generally supposed. For example, some American trees, like the black walnut and the tulip tree, which make noble specimens in the Thames valley and farther south, are often poor and stunter in the north of England and Scotland. The Chinese Paulownia imperialis, which is magnificent in Paris, is unlikely ever to succeed in any of our towns. New and rare trees, which may be seen flourishing at Kew, Glasnevin, and other botanic gardens, ought to be tried in town parks and spaces blessed with good soil, and not in streets, where all the conditions are unfavourable.

Different species of trees vary much in the quantity and density of their foliage, and this affects their suitability for planting in streets. Some kinds, as the beech, carry a dense heavy crown of leaves, under whose shade nothing can grow. Trees of this class are not desirable in streets, as they keep the roads and pavements wet for long periods after rain, and prevent sunshine from reaching the houses in narrow streets. Other sorts of trees, of which birch and Robinia are good examples, bear light and sparse foliage, which casts little shade. Such trees are suitable for street planting.

The size to which trees will grow in time is a matter of importance, as it is only in great wide streets that trees of the first magnitude can be safely planted. The form of trees must also be considered. In confined sites and narrow streets, trees of a columnar or narrow pyramidal habit are the most suitable.

A few remarks on the species most suitable for towns will be useful. 
The London plane (Platanus acerifolia) is the tree which succeeds best in streets, not only in England, but on the continent of Europe and in the United States. This remarkable tree is unknown in the wild state, and is undoubtedly a hybrid, which appears to have originated in this country about 260 years ago. The parents were the oriental plane (Platanus orientalis), native of the Levant, and the occidental plane (Platanus occidentalis), common in the forests of eastern North America. To its hybrid origin may be ascribed the extraordinary vigour of this tree, which enables it to remain healthy under the most unfavourable conditions of soil and atmosphere in towns. It is invariably propagated by nurserymen from cuttings. When raised from seed it produces a varied progeny, none of the seedlings reproducing exactly the parent, some approximating in foliage to Platanus orientalis and others to Platanus occidentalis, an evident proof of its hybrid origin.

The original type is represented by many fine old trees in the London squares, and has been much planted in the streets of the metropolis. It is a wide-spreading tree, with horizontal and pendulous branches, and attains in good soil an enormous size, as is evidenced by the wonderful specimen at the Ranelagh Club, Barnes. Two other forms are known, both of which are probably seedlings. One named var. pyramidalis is said to have come from Holland about thirty years ago, and is readily distinguishable by its narrower and stiffer habit, with ascending branches and dense foliage, the leaves being less deeply cut than those of the typical form. The pyramidal variety is now much planted in towns throughout the British Isles, and is scarcely less vigorous than the original form. The other form, Platanus acerifolia, var. hispanica, is now very rare in cultivation, and, so far as I know, has never been planted in English towns. It form\$ at Kew a tall straight stem, with branches not so pendulous as those of the type, and bearing remarkably large leaves, very distinct in outline. This beautiful tree, on account of its graceful habit and magnificent foliage, is well worth propagating, and should be tried in parks and streets. All 
the specimens which I have seen appear to have come from Van Hontte's nursery in Belgium, where they were grown under the name Platanus orientalis, var. californica.

Birch is a most useful tree in towns, and the silver birch (Betula verrucosa), which resists drought mueh better than the common species (Betula pubescens), should always be chosen. It also succeeds well where there is much lime in the soil and is very beautiful both in summer and winter, with its pendulous branches and very white bark.

Poplars thrive in towns and succeed in heavy clay soils where other trees fail. The European black poplar, P'opulus nigra, may be tried in streets, but its foliage and form are unattractive, and its trunk develops ugly burrs when old. The Lombarly poplar, a male tree always propagated by cuttings, which originated as a sport in Northern Italy about 200 years ago, has been styled the 'Exclamation Point' in landscape arehitecture, and it can often be used effectually in towns. The hybrid black poplars, which have been produced accidentally by the crossing of the European and American speeies, include several kinds, of which the black Italian poplar (Populus serotina), a male tree, and the Eucalyptus poplar (Populus regenerata), a female tree, are the commonest in eultivation in England. They grow speedily to an immense size, and on that account are unsuitable for ordinary street planting. In town parks they should be avoided, as they do not harmonise with other trees, which they speedily overtop; while in windswept districts they are likely to be smashed by gales. If, however, a quick effect is desired, the best of these hybrids is Populus robusta, a narrow tree with branches ascending at an angle and not directed vertically upwards as in the Lombarly poplar. This is well suited for making an avenue or line of trees in a park, that would attain a great height in a few years, its average rate of growth being about three feet annually. The white poplar (Populus alba) and the grey poplar (Populus ranescens) have beautiful foliage, and are much more desirable for street planting than the black poplar. Bolle's poplar (Populus alba, var. Bolleana), the 
fastigiate form of the white poplar, resembling the Lombardy poplar in shape, but distinctly wider with less upright branches, has been recommended for streets; but I have never seen it used. It should be tried as it is a beautiful tree in habit and shape, and succeeds well in Kew Gardens. It would probably thrive in the north, as it comes originally from Turkestan, where the winters are extremely severe. The balsam poplar, with balsamic odour of foliage and buds, occasionally seen in London streets, is Populus candicans, a female tree of unknown origin. It bears smoke well, but is unsuitable for streets, as its suckers come up freely through ordinary pavements.

Ailanthus glandulosa, a native of China, is a fine tree with magnificent pinnate foliage, which thrives and bears smoke well in towns in the south of England. It does not sncceed, however, in Scotland or Ireland, where there is not enough leat in summer for the well-being of this species.

Robinia Pseudacacia, an American tree, commonly but erroneously called 'Acacia,' is a successful street tree, very desirable on account of its pure white flowers and graceful foliage, the latter remaining fresh and green even in the driest summer. It suffers, however, much from wind, and in Ireland, Scotland, and the west of England and Wales should not be planted except in warm sheltered situations. A form of this tree, known as var. Decaisneana, which produces handsome pink flowers, and appears to be more vigorous than the type, is well worth planting as a street tree. Var. pyramidalis resembles the Lombardy poplar in shape, and is also suitable for streets.

The common ash, Fraxinus excelsior, thrives fairly well in parks in London and other cities; but it is unsuitable for planting in streets, as its foliage is both late in coming out in the spring and early in falling in autumn. It takes up a great deal of space, and has wide-spreading roots, so that shrubs and other trees do not flourish in its immediate vicinity; and on this account it is not fit for town gardens. Two of its varieties, the weeping ash (var. penulula) and the 
one-leaved ash (var. monophylla), are very distinct in appearance, and may be achmitted into town parks and gardens.

The ordinary species of lime, which have the leaves green on the under surface, namely, the common lime (Tilia vulgaris), the large-leaved lime (Tilia platyphyllos), and the small-leaved lime (T'ilia cordata), are unsuitable for the centre of towns, as they do not thrive in smoke or drought. They are also objectionable in gardens, on account of the viscid honeydew which is exuded by their leaves. The silver limes, with leaves white beneath (Tilia alba and Tilia petiolaris), have not been much used in street planting; but they would succeed much better than the common species.

The horse-chestnut, which is splendid in parks, is poor in streets, where it grows badly, as a rule, on account of the smoke and lack of moisture. As it comes early into leaf it is occasionally cut by spring frosts, which impair its vitality. Some people also object to its abundant fall of buds and flowers in the spring and of leaves and fruits in the autumn; but such debris is readily removed. In the streets of Paris the horse-chestunts, which were formerly very fine, appear now to suffer much from smoke, which canses their leaves often to turn brown in summer and to fall off prematurely. The red-flowering horse-chestnut (Aesculus carnea) is a smaller tree of hybrid origin, which resists better unfavourable conditions of soil and atmosphere. Compact in habit, and bearing attractive flowers freely at an early age, it can be recommended for gardens in smoky towns. It succeels well in Kensington Gardens, London.

Of the numerous species of maple, the best for planting in towns is the Norway maple (Acer platanoides), as it does not attain a very great size, is compact in form, is remarkalily free from the attacks of insects or fungi, and withstands smoke well. It cones into bloom very early in the season, the conspicuous greenish-yellow flowers anticipating the leaves, whilst in atutumn the foliage turns before falling a brilliant yellow colour. It is much more attractive in appearance than the sycamore or great maple (Acer pseudo- 
platanus), which is more frequently planted. Both trees resist wind well, and can be freely used in seaport towns. The Norway maple is a favourite tree for planting in American cities, being considered superior for that purpose to any of the native species; and it is strange that it is so seldom seen in our streets.

Elms are much planted in towns, but are often unsuccessful, as the proper kinds have not been chosen. The English elm (Ulmus campestris of English authors) is a beautiful tree in the south of England, retaining its foliage, which turns a brilliant yellow, till late in October, long after other kinds have lost their leaves. It grows to a large size, and is unsuitable for streets on that account; moreover, it suffers badly from smoke. In párks it must be planted with discretion, as old trees are liable to drop their branches in calm weather without warning, and have been the cause of fatal injuries. The English elm, it must be remembered, is distinctly a southern tree, and it does not thrive well in Scotland and in most parts of Ireland. The wych elm (Ulmus montana) grows to a great size, and succeeds fairly well in windswept localities. It is suitable for planting in town parks in Scotland, Northern England, and Ireland. The weeping wych elm, of which there are two distinct varieties (6) (var. horizontalis and var. Camperdounensis), is much planted in parks and cemeteries, and thrives in Edinburgh and Dublin as well as it does in London.

The elms, which are imported as seedlings from French nurseries under the name Ulmus campestris, are quite distinct from the English elm, and are now correctly named Ulmus nitcns. They have been largely planted in Edinburgh and other towns, but are not very successful in resisting smoke and drought. The best elm for planting in streets is undoubtedly the Jersey or Wheatley elm, which assumes a regular pyramidal form. The Cornish elm (Ulmus stricta), less regular in shape but similar in foliage to the last, bears wind extremely well, and should be tried in gardens and streets of sea-coast towns. The Belgian elm 
(Ulmus latifolia) (7), a tree of hybrid origin always propagated by layers, is magnificent in the streets of Holland and Belgium, but it does not seem to be successful in England; at least it is very rarely seen in our towns, though it has been imported from time to time.

Oaks are seldom planted in streets. The common oak requires good deep soil for its proper development, and languishes in the poor soil and bad air of towus. In suburban avenues, the fastigiate or cypress oak (Quercus pedunculata, var. fastigiata), similar in shape to the Lombardy poplar, would be very ornamental, and prove successful, provided the soil were a deep loam or loamy clay. In the milder parts of England, Ireland, and Scotland, the Turkey oak grows well on poor soils and in dry situations, and should be tried in suburban streets, where it grows fast when there is not too much smoke. The American red oak (Quercus rubra) attains a large size in the south of England, where it grows faster than our native species. It does not require a rich soil, and on account of its handsome foliage, turning red in autumn, should be tried in town parks and wide suburban streets in the milder parts of England and Ireland. Its ally, the pin oak (Quercus palustris), has drooping branches and beautiful leaves, turning a rich scarlet colour in autumn. It requires a moist soil, and is unsuitable for use as a street tree in England; but it would probably succeed if planted near water in parks and gardens, as there are fine specimens at Kew and in other parts of the Thames valley.

There are numerous small trees, with beantiful flowers and fruits, which are fairly successful in towns. Amongst these may be mentioned various species of Pyrus and Prunus, as whitebeam, rowan, almond, bird-cherry, and gean, all of which can be freely used in manufacturing towns with a smoky atmosphere. Laburnum and mulberry also do well. The two American species of Catalpa, with conspicuous flowers and large leaves, may also be recommended for town garlens. Liquidambar styraciflua, an American tree with maple-like leaves which assume 
beautiful tints in autumn, is worthy of trial in parks and gardens.

As mentioned above, scarcely any evergreen tree can be recommended for planting in the smoky areas of large towns. Of the smaller broad-leaved evergreen trees and shrubs, that is, those which do not belong to the conifers, the most resistant to the evil conditions of towns are probably box, Euonymus and Aucuba. If hollies are to be planted, it is decidedly of advantage to select the vigorous large-leaved kinds, which are of hybrid origin, such as Ilex Hodginsii, I. Mundyi, I. Wilsoni, I. nigricans, and I. camelliaefolia. In seaside towns one of the most. useful trees is the evergreen oak (Quercus Ilex), which is excellent as a wind-screen.

Scarcely any conifer will succeed in the interior of a smoky town, the most resistant being probably the Austrian and Corsican pines, which have also the merit of withstanding wind well and of thriving in most soils. Conifers appear to be more sensitive than other plants to smoke or dust. This is due to their leaves having peculiar sunk stomatic openings which are designed to check transpiration, but form efficient traps for particles of soot or dust. It is

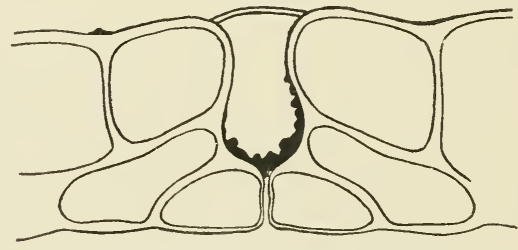

FiG. 6. -Stoma of leaf of Silver Fir, showing deposit of soot.

(From Cohen and Ruston, Smoke.)

by means of the stomatic openings that the gaseous interchanges take place in the leaf; and if these openings are blocked, the assimilation of carbon dioxide from the air is stopped and the plant is no longer able to obtain food. Conifers may occasionally be useful in town parks in 
providing shelter, but they cannot be utilised in streets. The curious Chinese maidenhair tree (Ginkigo biloba) thrives in London, and is worthy of a place in town parks and gardens on account of the remarkable beauty of its foliage.

In the planting of streets it must be remembered that trees die unless their roots are freely supplied with air as well as moisture. Pavements, such as asphalt, which seal up the soil from access to the air, render the growth of trees impossible. The planting of trees, as is now usually done in English towns, with grilles or iron gratings around their bases, which are supposed to admit sufficient air and moisture to the roots, is a poor practice. Trees planted in this way never do well. Moreover, the gratings are expensive, and in all probability are not more effective for the admission of air and rain than ordinary gravel. The universal practice in America of planting trees along a continuous strip of grass turf should be adopted wherever possible. The width of the grass strip should be at least 4 feet. The narrowest street which can be conveniently planted is 50 feet wide; and this may be divided into a 30 -feet roadway with two footpaths each 10 feet in width, the latter consisting of a 6 -feet pavement next the houses and a 4 -feet planting strip next the curb. A broad strip of turf between the walk and the curb enhances the beauty of the street, and gives the trees a better chance of vigorous life.

Streets 60 feet wide are ideal, with a roadway 30 feet wide, and footpaths each 15 feet wide, on which can be laid out a lawn strip of 6 feet. In residential quarters, the houses are usually set well back, and at some distance from the footpaths, which gives more room for the trees to develop. In Paris no trees are planted on streets with tall buildings, which have footpaths less than 13 feet wide and roadways 20 feet wide. Narrow pavements and sharp corners of streets are unsuitable for trees. Trees should be set about 40 feet apart in the line, alternately in the two rows in a street.

Free-growing, clean, healthy young trees with good roots must be chosen; and the best size is about 2 to 3 inches in diameter. The single stake is best, such as a larch pole, 
14 feet long, with its base stripped of bark and tarred, driven well into the ground. The tree, covered with a strip of tarred felting, is tied to the stake in two or three places, with $\frac{1}{4}$ incl Manila rope slipped through a piece of indiarubber hose, about 8 or 9 inches long. This prevents the stem of the tree from coming in contact with the stake. The ties attaching the trees to the stakes must be loosened in time, so that they may not eat into the bark.

Pruning is necessary, but only in order to take off the lower branches, so as to allow unimpeded the passage of pedestrians and vehicles; and also in rare cases, as in narrow streets, where trees must be kept in a limited space. Pruning is expensive; and the performance of a surgical operation on a tree is no more to its good than the same on an animal. The appearance of trees in towns, not only in streets, but in parks, with their trunks marked with great scars or wounds, is very distressing, and is, moreover, the cause in many cases of disease and death. The spectacle of untrained men going about hacking trees in towns is a painful but common one. The whole art of pruning is to cut away in time the branches that must be removed, that is when they are small, say less than $\frac{1}{2}$ inch in diameter; and to cut only a little at a time, applying a dressing of coal tar to the freshly cut scar. Trees require all their branches in order to grow vigorously, and, left to themselves, they generally make a finer bole than if maltreated. All the so-called systems of pruning trees are to be avoided. If you ever prune, prune so that the tree looks as if it had not been pruned at all. Dead wood, of course, can be removed.

People will be more interested in the preservation of trees if they know something about them. It is advisable then to place one or two inscriptions in each street, giving the date of planting and the names of the species used.

The preservation of trees is as important as their planting; and in every large town it is advisable to form a committee to look after the trees. Sometimes a beautiful tree is felled or sound branches are lopped off, and the timber subsequently sold by untrustworthy borough servants. 
The careless laying of water pipes and electric mains causes the death of many trees. Changes in the level of a road or street often involve the destruction of trees. The old tree in a village, at a cross-roads, or in the market-place of a small town, ought to be guarded with great care, as it gives to each place its own peculiar aspect, and causes it to linger in the memory of those who have left their early home.

\section{NOTES}

1. See W. Solotaroff, Shade Trees in Towns and Cities, p. 4 (1911).

2. See A. Rigg in Journ. R. Sanitary 1nst. xxvii. p. 160 (1906).

3. An interesting account of the effect of the smoke of Glasgow on trees growing on the Pollok estate is given by John Boyd in Trans. Roy. Scot. Arbor. Soc. xvii. 122 (1904). He distinguishes elearly the effects of aeid in the snoke, of soot, and of the darkened atmosphere. "A leaf affected by acid, if held up in a strong light, slows little clear spots, wherever the action has begun. Through time these spots usually become brown, almost black in some plants. A clear margin is seen around the coloured part, which distinguishes it from any fungus disease. This form of injury is generally attributed to sulphurous acid gas, and may be seen more or less in almost all speeies of broad-leaved trees growing in a smoky district; but the various trees are not all affected to the same extent." Horse-chestunt is very badly injured in this way. The oaks, especially Quercus Cerris, withstand acid in the smoke better than any other species. Ash is next in resisting power, followed by elm and syeamore. Service trees, bireli, and rowan are little affected, and are very suitable for smoky localities, as they are not so partial to a good soil as the trees just mentioned. Boyd correctly attributes the illhealth of conifers at Pollok to the choking by soot of the stomatie openings of the leaves. Scots pine, which suffers very badly, showed when the needles were examined almost every pore to be more or less closed by soot. The leaves of Scots pine also fall off prematurely, "it being quite common to see then at the beginning of the growing season with nothing but the previous year's leaves adorning them, instead of two years complete and the greater portion of the third, thus giving them a thin, tufted, stmnted, and unliealtliy look." The diminution of increment of growth in the Pollok plantations is also remarkable, amounting in the case of broad-leaved trees, like oak, ash, sycamore, beech, elm, hornbeam, birch, service and rowan, and in Austrian pine, to 10 or 20 per cent, and in the case of the worst sufferers, Seots pine, Weymouth line, and spruce, to 20 to 40 per eent. The number of stems per acre is also reduced, so that it is absolutely impossible to cultivate trees successfully from a commercial point of view in any smoky locality.

The effect of the smoke of blast furnaces, of numerous passing locomotives, etc., on neighbouring trees in narrowing the annual rings is well described and illustrated by J. F. Clevenger in Mfellon Institute, Philadelphia, Smoke Investigation, Bulletin No. 7 (1913), "The Effect of the Soot in Smoke on Vegetation." See also American Forestry, Dee. 1917, p. 732. A. L. Bakke, in Ioura State College of Agriculture, Bnll. 145 (1913), established that the vegetation about a manufacturing concern can be marped in concentric zones, 
each belt having a certain form or forms of plant life, since certain species are more susceptible to smoke injury than others.

Crowther and Ruston summarise the results of several years' experiments and observations on the effect of smoke on plants in and around Leeds in Brit. Assoc. Report, 1915 , p. 780 (1916), from which we may quote: "Trees and shrubs make only a stunted growth; dead and dying trees are common objects. Conifers are particularly sensitive. Destruction of young shoots and buds is noticeable. Characteristic discoloration of leaves takes place apart from the inevitable coating of tarry soot, and the fall of the leaf is greatly accelerated. The colours of flowers fall short of their normal intensity. Previous observations on the choking of stomata by soot particles have been confirmed. In the garden tests within the city boundaries, the produce (three crops) obtained in the 'cleanest' garden was fully three times greater than that obtained in the 'dirtiest' area. In soils long exposed to smoke pollution, there is a marked faikure of root-development, root hairs and fibrous roots being few or absent." See Cohen and Ruston, Smoke, $\alpha$ Study of Toun Air (1912); Ruston, Report of Smoke Abatement League of Great Britain, pp. 44-53 (1911); Pierce in Popular Science Monthly, 1911, p. 332 .

4. The chief cause of injury to vegetation, due to the smoke of copper smelting works, is sulphur dioxide, according to Haywood in U.S. Dept. Agric. Bur. Chem. Bull. 113 (1908). In deciduous trees the injury, when acute, consists of irregular reddened areas of dead leaf-tissue between the veins. The region in the immediate vicinity of the midrib and principal veins is last to be affected. Repeated acute injury of this sort kills the twigs and finally brings ahout the death of the whole tree. Deciduous trees in $\mathrm{S}$.E. Tennessee appear to be more resistant than conifers, and are resistant in the following order, the most highly resistant being named first: Quercus alba, Acer rubrum, Populus deltoides, Liriodendron tulipifera, Robinia Pseudacacia, Platanns occidentalis, and Ulmus crassa. See G. G. Hedgeock in Journ. Wash. Acad. of Sciences, iv. (1914) p. 70.

The vegetation at Foyers, Inverness-shire, is affected by the dust of the cryolite carried by the wind from the British Aluminium Works. Coniferous trees are being killed, whilst deciduous leaved trees remain uninjured. See G. West in Proc. Roy. Soc. Edinburgh, vol. 25, pt. 2, p. 995, fig. 25 (1906).

5. An investigation into the injurious effects of tarred roads upon neighbouring trees has been made at Milan by U. Brizi. The trees most susceptible are the common horse-chestnut (Aeseulus Hippocastanum) and the red-flowering horse-chestunt ( $A$. carnect), the leaves of which, at the beginning of summer, turn rusty at the edge and curl up slightly, while their surface is covered with numerous small spots which at first are yellow and look as if eovered with a thin layer of shining varnish. The leaf then curls up more and more, dries, and is blown away. Another sensitive tree is the beech. The damage is caused almost entirely by the very fine dust due to the passage of motor-cars. The dust settles slowly and is most abundant on the lower branches of the trees. Once deposited, the small particles of tar give off injurious vapours when strongly heated by the sum. The parts not directly reached by the sun never show this damage. The best remedy is to keep down the dust by the regular and abundant watering of the roads. Scientific American, 2nd Nov. 1918, p. 351.

6. See A. D. Richardson in Trans. Scot. Hort. Assoc. vol. ii. part i. pp. 80-82, Plates I., II., III. (1913).

7. See Elwes and Henry, Trees of Great Britain, vol. vii. pl. 1869-1871 (1913). 


\section{CHAPTER VI}

\section{AFFORESTATION OF ['IT MOUNDS}

In the Black Country of South Staffordshire and North Worcestershire, smoke and flame are poured forth day and night from innumerable chimneys, rendering the atmosphere gloomy and unhealthy. Many spots, once green fields and woodlands, are now covered with pit mounds-great heaps of slag, shale, and coal waste (Fig. 8). These render the landscape desolate, as they are poorly clad with vegetation, and assist by their depressing nature the bad effect of the atmosphere on the physical and moral health of the population. The efforts to afforest these barren heaps and cover them with the verdure of trees is an important hygienic measure.

The Black Country has at least 30,000 acres of pit banks, about 14,000 acres of which are suitable for planting at the present moment; and the other coal-fields of Great Britain have many times this area available for afforestation. The Midland Reafforesting Association (1) was founded on 12 th February 1903, with the idea of getting rid of the depressing desolation of the pit and factory rubbish heaps, and "to re-establish forestry as a business in the Midlands."

The plantations made by the Association, though only experimental and on a small scale, have been successful not merely in beautifying the landscape, but have also actually shown the possibility of prodncing profitably timber of a useful kind on these barren waste heaps. It is only 
the old pit banks that will grow trees, as the slag and slate must weather for a long time before a suitable soil is formed. This soil is so poor that it can scarcely ever be turned to agricultural use; yet it can be clothed with sound plantations of certain species of trees. The planting of these hideous mounds, which are an eyesore to the people, will be made compulsory after the war, if the principle is carried out that all waste land shall be made productive. An additional reason for such afforestation is the salutary effect of the experimental plantations on the moral health of the children and of their parents; and any measure that increases the joy of living in dreary neighbourhoods must be welcomed in the future.

The pit banks are of three kinds. Those consisting of furnace slag need not be considered, as this material is of some money value, and is gradually removed "for railway ballast. Coal waste or carbonaceous shale, accumulated in mounds, generally takes fire and in some cases burns for years, giving as a final result a soil of red and friable ash, which supports tree growth fairly well. The third kind of pit bank made up of clunch or shale is not a promising ground for trees, but certain species will succeed on it.

Planting of pit mounds and similar waste ground has been done on the Continent, but little has been attempted in England, though one colliery is reported (2) to have drawn for some years pit props from its own spoil heaps. Walsall Town Council planted one pit bank at its own expense in 1886, which is now known as Reed's Wood Park. Mr. Martineau had it valued when it was 16 years old, and it worked out at $£ 17$ per acre as it stood. The belts of timber that are now visible there show what valuable tree growth can be obtained. The Midland Reafforesting Association, however, had to contend with much apathy in the beginning, and could only secure very small areas, which have been planted on various terms. Some plantations have been formed for the landowner by the Association at a contract price for planting, fencing, and replacing dead trees for a period of some years. The 


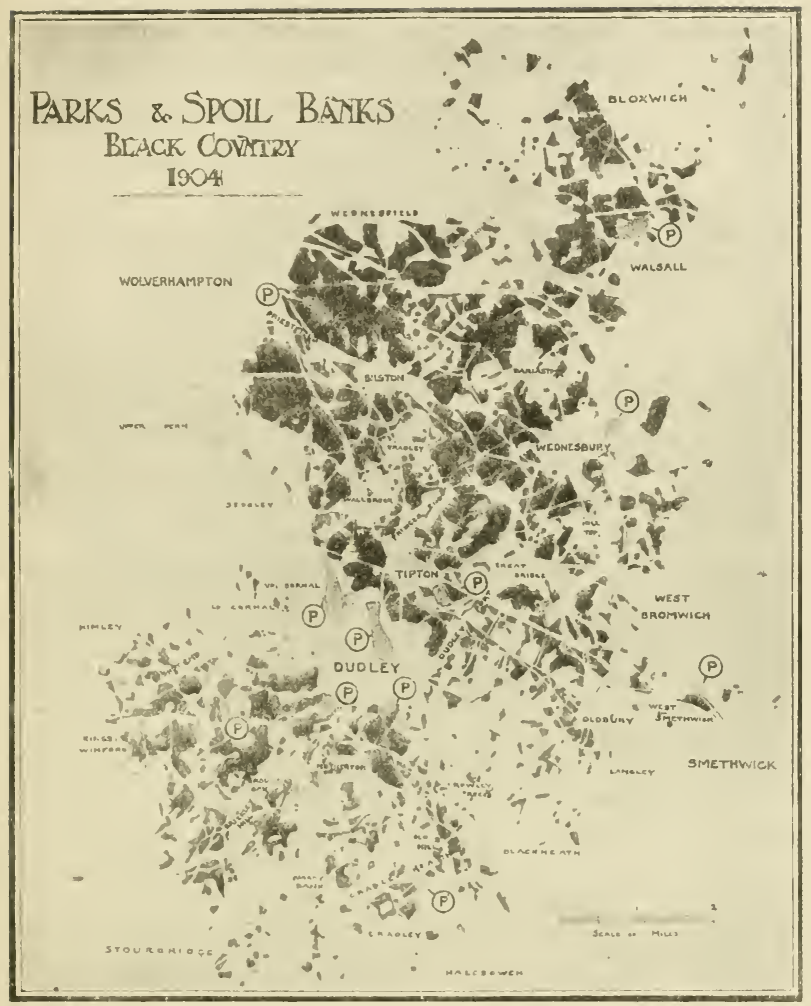

F1r. 7.-Parks and Spnil Banks, Blark Country. 
Association, in other cases, has taken the pit bank on lease. When the spoil banks have been owned by District Councils or other Corporations, the Association has supplied the trees and given advice; while the labour, which is nearly always casual yet satisfactory, has been paid for by the public bodies. In one case, the Moorcroft Plantation, the Association has been helped by two grants, amounting in all to $£ 150$, from the Development Commissioners. A most interesting feature has been the starting of plantations by about a dozen Board Schools. The Churchyard of West Coseley has been planted, at the instance of the Association, with 400 trees, which will in time grow into a small wood of great value in improving the amenities of the landscape. Waste land adjoining the sewage farm at Kidderminster and the shale mounds beside the Stanfield Sanatorium have been planted by the local authorities on plans suggested by the Association.

The manifold activities of a voluntary association are here manifest. Unhampered by red tape, and with enthusiasm in lieu of pecuniary resources, such an association has made valuable experiments of a varied character, based on which more extensive work can be carried out in the future, either by the local authorities or by the Forestry Board, which we hope to see constituted after peace comes.

Attempts were made at first to establish timber growth on the mounds by sowing broadcast the seeds of forest trees in situ; but this method proved a failure and was abandoned after 1904 . The planting of two- or three-year-old seedling trees is now invariably the practice; and the only seeds now sown are those of shrubs like gorse and broom, which are intended to act as temporary screens. Natural seedlings of birch may, however, be seen on the big mound at Timber Tree Colliery, Cradley Heath, which was planted with birch in 1886 . These seedlings, Mr. Martineau tells me, creep north-east quite steadily, following up the fiery part of the mound as the fire retreats.

The technique of planting has been simple, the main difficulty and expense being the proper fencing of the 
plantations and their continued protection. Herein lies the importance of enlisting in such a movement the active help and sympathy of school children and their parents.

The species used have varied with the nature of the soil and atmosphere. The Black Country, on account of the acid fumes from its chimneys, is not favourable to conifers; but the Association has begun to plant Sitka spruce, while in some districts larch, Scots pine, and common spruce might be tried. The tree which succeeds best, not only on the loose and friable ash, but also on the refractory shale, is the common alder. Birch thrives on the ashy soil, except where the fumes are unusually dense. On considerably weathered mounds, on which grass is growing, ash, sycamore, and wych elm thrive fairly well. The black Italian poplar is usually planted around mounds; and, as it grows fast, serves as a protection belt. This shelter is required, as most of the pit banks are 500 to 700 feet above the sea and are much exposed to strong winds.

The wood of the two most successful species, alder and birch, is marketable at good prices in Birmingham and in the Black Country, being much used for handles of small tools, of electric switches, and of different utensils. They are sought for by the numerous wood turners of the district, as well as by many firms which make their woodfittings in their own works. The cost of planting has been about $£ 6$ per acre for trees five feet apart, in addition to 1s. per lineal yard for fencing; but it would be better to plant the trees four feet apart at a greater proportionate cost. The growth of the trees has been good, birch and alder set ont in 190i-1908 being now 18 to 24 feet high, while poplars in 1916 had attained in some belts as much as 30 feet. There are altogether 36 plantations, the largest (Mnoreroft) being 34 acres. The others are considerably smaller, $\frac{1}{4}$ acre to 5 acres. The total area planted is 82 acres.

The work of the Midland Reafforesting Association has been greatly encouraged by the Education Committee of the Rowley Regis District C'ouncil. The history of one of 
the school plantations will prove of interest. When the new schools at Doulton Road were opened on 29 th November 1909, the ground (Fig. 9) around the buildings which was not needed for play was devoted to planting. This was carried out, the occasion being made an Arbor Day festival. Five hundred trees were planted by the teachers, scholars, and members of council, each one being labelled with the name of its planter. In 1916, 7 years afterwards, the trees averaged as follows:

Poplar, 18 feet high, 14 inches in girth at 3 feet from the ground.

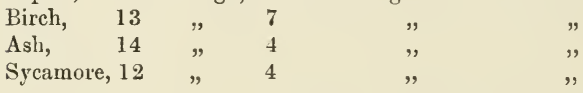

Fig. 9, from a photograph taken in 1913, shows the growth of this plantation.

Mr. Teague, the head master, informs me that the interest taken in the trees by the school children and their parents is very marked. Observation lessons in the school plantation, and in the Black Waggon plantation at some distance off, are systematically carried out. These observations are partly meteorological, on rainfall, direction and force of the wind, effects of late frost and drought. The trees, fungi, and insects are studied, and lessons on geology, chemistry, and hygiene are given in relation to the life of the trees. The children and their parents have been quick to see that, like the trees, they themselves need more light, air, sunshine, and cleanliness. Habits of observation and reflection are induced and fostered; and healthy instincts are implanted in the growing minds. Mr. Teague has noticed a great improvement in the manners of the children, whose physical health has been improved by the digging, staking, and other work, as well as by the observations taken in the open air in the plantations. The children become less fond of exciting town amusements, like the cinematograph. The civic sense has become developed; and the trees are guarded and protected by the boys, supported by the public opinion of their parents.

Mr. Evans of Wright's Lane Council School, Old Hill, 


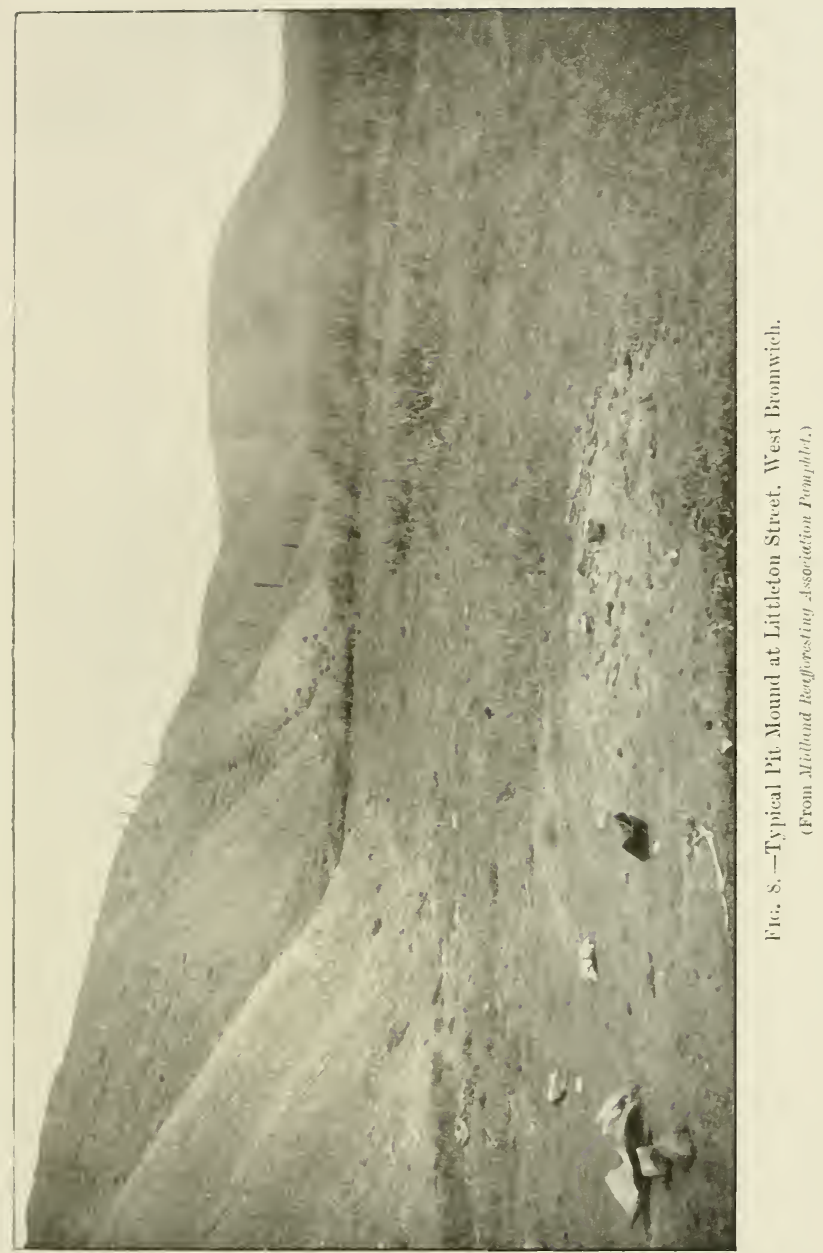




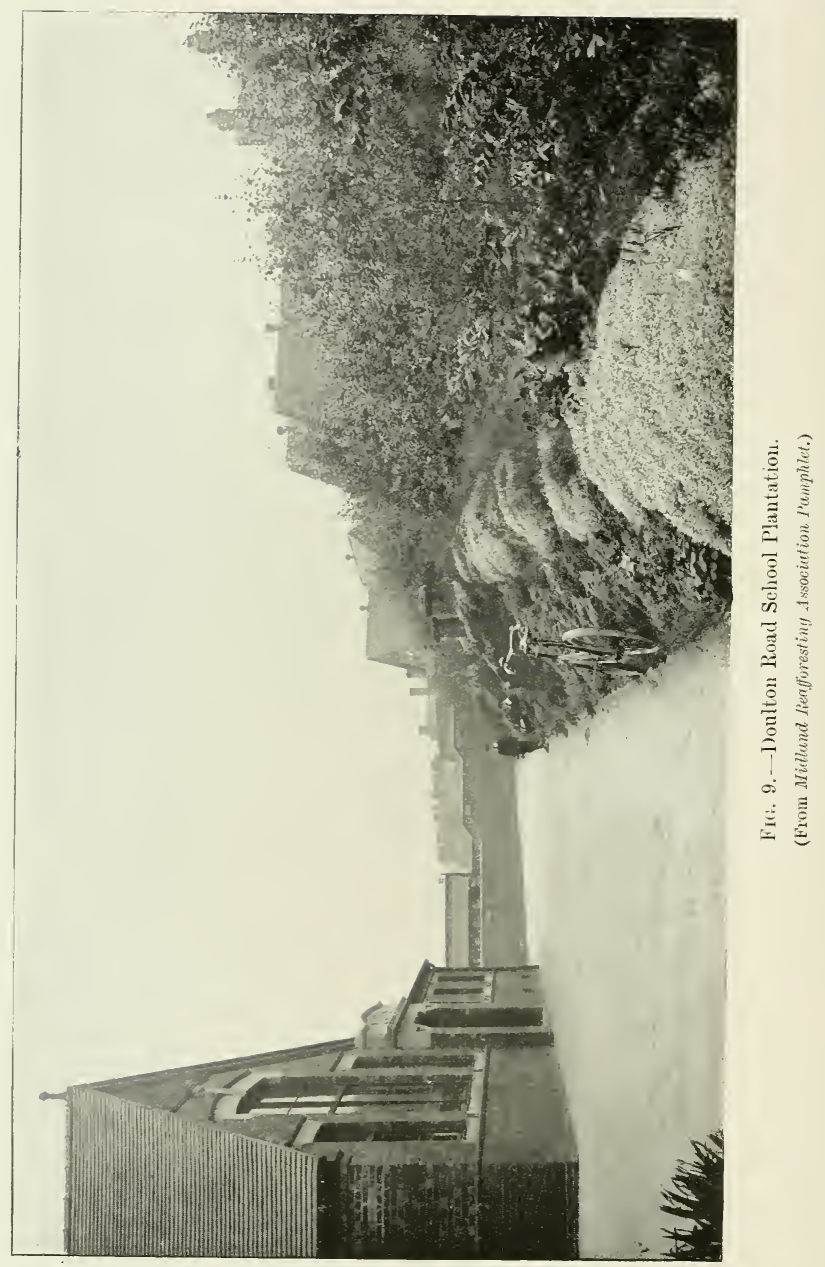


Staffordshire, where 100 trees have been planted in the playground, says that the influence on the children has been uplifting. The district is inhabited by a rough class, yet the absence of vandalism is now noticeable. Here, however, the tree-planting is too small in its scope to have effected as yet any great change in the tone, manners, and spirit of the people. Mr. Martineau confirms the remarks of these teachers, and says that the plantations have had a most cheering effect on the people near-by. Some of the plantations are regarded by the neighbours with positive affection.

The Black Waggon plantation, which has been taken charge of by the Higher Grade School of Rowley Regis Parish, is a fair example of the average growth to be obtained in this kind of forestry. This mound consists partly of grey shale and partly of shale mixed with slack. The slack was fired and much of the ground is burned out. One part is still hot, and has naturally not been touched. Alder has been planted on the sticky grey shale; birch on the burnt-out part, a loose and very friable soil; and black Italian poplar on the lower slopes. Some other species have been tried experimentally, chiefly at the base of the mound, viz. willow, sycamore, wych elm, grey alder, Robinia, and Sitka spruce; but thorn and Austrian pine have failed, and the soil is not good enough for sycamore. Black Waggon mound was planted in $1907-1909,2 \frac{1}{2}$ acres being covered with 5000 trees; and the average measurements of the three chief species in November 1916 were:

Poplar, 19 feet high, 10 inches in girth at 3 feet above the ground.
Alder, $17 \frac{1}{2} \quad$,
Birch, 16
8
7
", ",

The even growth, due to close planting, is remarkable; and this huge black bald mound, formerly an eyesore to the district, is now covered with splendid trees, likely to develop into good timber. The Midland Reafforesting Association has proved that valuable plantations of certain 
species can be established on pit and spoil mounds, improving the amenities of the district and constituting a hygienic measure of some importance. In other colliery districts the lesson ought to be taken to heart. All districts should organise themselves to supply the shortage of timber that is certain in the future, instead of leaving thousands of acres to waste which bring in no rent and no profit. This work is capable of great extension, but in localities with chemical works trees may prove unsuccessful.

The School Plantations of the Black Country may be imitated in all parts of rural England and in the sister countries. In some parts of France little forestry societies (3) have been formed in connection with the schools, a movement due to M. Mayet, schoolmaster at Avignon-lèsSaint-Claude (Jura). There were in 1910 about 200 of these little societies, which develop among the children the love of trees and the elements of forestry. Moreover, the scholars themselves make plantations under the direction of the teachers, and already in 1910 they had planted some hundreds of acres and set out more than 2,000,000 trees in the communal forests. Certain communes in the east of France have set aside for the scholars experimental plots, well fenced and netted, where experiments in planting and raising seedlings have been carried out, resulting in some cases in the initiation of improvements in the great forests. In the regions of the Loire and Vosges some of the school forestry societies have been given funds by generous donors, which are applied to the acquisition of land for planting, the proceeds of the woods so created being assigned to the schoolmaster as a supplement to his pension.

Just as the tiny seed may become a great tree, so these little village and school societies may become the nucleus of great social progress. To get the scholars and the teachers into the open air, and in touch with farming, gardening, and forestry, will be the great step towards the hygiene of the Social Organism.

I may here add some notes concerning the reclamation 
of pit mounds by private owners. The Scremerston Old Colliery Mound was successfully planted in 1887, at the instance of Mr. John Davidson, agent of the Greenwich Hospital estate in Northumberland. This mound, which had long been a high and bare unsightly heap on the side of the Old North Road about three miles south of Berwick, is now a pleasing tree-clad hill. Mr. D. Smith, the forester who actually carried out the planting, tells me that three species ware tried-larch, Scots pine, and birch. 'The birch trees did not thrive, and were early removed as thinnings. The Scots pine proved most successful, and are now fine trees, 30 to 40 feet in height. The growth has been best on the part of the mound which had been on fire. The success of this plantation, which is fully exposed to the west wind, is remarkable. The difficulty of establishing trees in the loose shingly refuse of this high and exposed mound was overcome by planting first a few rows of trees around the base of the mound, and in the shelter thus obtained, continuing with a few more rows, and thus by successive bands in five or six years the whole mound was planted to the summit, which is nearly 100 feet high, without a single tree being blown out by the wind.

Mr. George Bolam, who has written an article (4) on the planting of pit mounds in Northumberland, mentions that in later years, and closely adjoining Scremerston, Lady Frances Osborne has successfully clothed with young trees some bare pit heaps that had for more than a generation disfigured her property at Ord and Murton.

The Charley pit bank near Mealsgate, Cumberland, about four acres in extent, has been successfully covered with trees. The colliery was abandoned in 1897 , and the first step taken was the sowing of rape and grass seed on the mound. The roots of the herbage thus obtained have helped in the disintegration of the surface. Planting was begun in 1898 , the trees being planted in holes, in each of which one or two buckets of good soil had been put. Numerous species were tried, of which larch, Scots pine, and birch have shown the most vigorous growth, the earliest planted 
of these being 18 to 24 feet high in 1912. Oak, ash, beech, sycamore, and elm also did fairly well. This is remarkable, considering the character of the mound, of which only the surface has disintegrated, the material beneath being caked into hard masses containing considerable quantities of pyrites. In spite of this, the trees have made nearly as good growth on the mound as trees of the same species in ordinary soil in the neighbourhood, according to measurements made by Mr. P. Murray Thomson (5).

In the colliery districts of Scotland a few attempts have been made to plant the spoil heaps, which are locally known as pit bings (6). When these consist of a mixture of shale and stones, trees grow readily, the best species being probably alder. Successful results have been obtained by Mr. Whitelaw at Gartshore, near Kirkintilloch. Mr. J. Milne Home sends me some notes about recent plantations on pit banks near Dalkeith. . On the upper bing on Wester Cowden Incline, which was an old colliery pit bank that had been left untouched for many years, an acre was planted in 1913 with 1200 sycamore, 450 birch, 2000 grey alder, and 1200 European larch. At present grey alder shows the best growth, while larch has done fairly well, but sycamore has been a failure. In 1914 about $2 \frac{1}{2}$ acres on the neighbouring lower bing were planted with 2300 sycamore, 500 birch, and 4200 grey alder. It will be interesting to watch the further growth of these two plantations. Before the war grey alder was procurable at a cheap rate from French nurseries as one-year and two-year seedlings. It grows with great vigour on most soils, and succeeds in windswept localities and in situations liable to late and early frosts. Its wood is equal in value to that of the common alder.

Mr. H. M. Cadell (7) tells me that about ten years ago he planted up some old colliery bings at Grange, Linlithgow, with Japanese larch, Scots pine, etc. The Japanese larch are now about 15 feet high, but a good many have died. These pit heaps, though forty years old, were not sufficiently disintegrated, and the dry undecomposed material 
did not look very promising for tree growth. A shovelful of good soil put in round the roots at the time of planting greatly assisted the growth of the young trees at the start. Mr. Cadell believes that in many districts pit banks, especially those at abandoned mines where there is neither smoke nor mischievous people to injure the trees, may be planted with a view to profit. Mining districts are usually provided with railways, and furnish a good market for any timber that is grown locally.

The immense shale banks around the oil works in West Lothian and other districts are difficult to plant. If iron pyrites is present, the sulphuric acid formed when the shale is decomposed prevents the growth of any vegetation. Mr. James Whitton instances shale bings forty or fifty years old at Nitshill in Renfrewshire on which not even a blade of grass has appeared. Some of the oil shale, however, supports plant growth fairly well, as is evident near Linlithgow, where Mr. Cadell has noticed the appearance of natural vegetation on abandoned bings. The latter might be planted with grey alder, black Italian poplar, etc. It must not be forgotten that the fumes from shale works are deleterious to the growth of trees, the effect being especially grave when sulphuric acid required for refining is manufactured at the works (8).

On an extensive slag heap at Quaregnon, in Belgium, planted up in 1891 with Robinia, alder, elm, birch, hornbeam, ash, sycamore, horse-chestnut, laburnum, etc., the best species appears to have been Robinia, which in eighteen years after planting had attained as much as three feet in girth. On another large slag heap, planted 25 years, hybrid black poplar was also three feet in girth. M. C. Leonard, who gives an account of these plantations in Annales de Gembloux, Oct. 1909, recommends that, after weathering for eight or ten years, a heap should be covered first with herbage by sowing seeds of grasses, lucerne, sainfoin, etc., and afterwards be planted up with 3- to 4-year-old transplants of Robinia, birch, grey alder, Prunus serotina, sycamore, and Quercus rubra. 


\section{NOTES}

1. See evidence of Mr. P. E. Martineau before the Royal Commission on Coast Erosion and Afforestation, Minutes of Evidence, vol. ii. part ii. pp. 241-243 (1909), and Quarterly Journal of Forestry, i. 150 (1907), and iii. 26-31 (1909).

2. In Collicry Guardian, 19th Jan. 1917, p. 125.

3. See Cardot, Manuel de L'Arbre, p. 80 (1911).

4. In P. A. Graham, Reclaiming the Waste, pp. 142-147 (1916).

5. See Trans, Roy. Scot. Arbor. Soc. xxvii. pp. 30-33, figs. 1-6 (1913).

6. See Trans. Roy. Scot. Arbor. Soc. xxxi. pp. 108-109 (1917).

7. Mr. Cadell, in Trans. Roy. Scot. Arbor. Soc. xxiii. 164 (1910), gives an account of the different kinds of pit mounds in Scotland. Some mounds are entirely composed of black argillaceous shale, locally known as 'blaes,' which is not unfavourable to tree growth. If, however, iron pyrites is present, as in some mounds, the sulphuric acid produced by its decomposition combines witl the alumina of the shale, forming sulphate of alumina or alum, a soluble salt, which is absolutely destructive to vegetation. The refuse produced in working oil shale in the Lothians is enormous in quantity, and usually goes on fire, being ultimately burnt into a red porous mass, which becomes slowly weathered and crumbling down on the surface, makes good enough soil in the course of time for the growth of larch, birch, and Scots pine. Colliery debris containing fire-clay breaks quickly down into ordinary clay, and may support vegetation well ; but if it contains bituminous matter, it will not decompose into a soil suitable for trees. Such black loose material, though devoid of pyrites, has lain in some instances for more than a century without accumulating much natural vegetation. It absorbs the sun's rays and becomes hot and dry in summer, so that plants have great difficulty in starting away at first.

8. See an article on "The Damage done to Trees by the Shale Industry" in Trans. Roy. Scot. Arbor. Soc. xvi. p. 470 (1901). 


\section{CHAPTER VII}

THE AFFORESTATION OF WATER CATCHMENT AREAS

THE afforestation of water catchment areas is a hygienic measure as well as a means of increasing the timber reserves of the nation, as will be shown after some preliminary observations on the water supply of our great municipalities. Some towns get their water supply from large rivers, as London from the Thames and Aberdeen from the Dee. Other towns are supplied by springs, wells, and deep borings of various kinds. The third method, which specially concerns us, is that of catchment reservoirs, constructed to impound the water falling on upland and sparsely peopled tracts. Such gathering grounds in the Pennine range supply most of the great centres of population in Lancashire, Yorkshire, and Derbyshire. Other catchment areas are situated in Wales, Cornwall, and a few other districts in England, and in many parts of Scotland. Natural lakes, often made larger by artificial dams, as Loch Katrine used by Glasgow and Thirlmere by Manchester, are in the same category as artificial reservoirs, and like these derive their water supply from the drainage of the surrounding watersheds.

In many cases the water authorities have only leased the water rights and have not acquired the ownership of the gathering grounds. For the prevention of pollution of the water, they have relied mainly on the 61 st Section of the Waterworks Clauses Act of 1847 , which makes it penal to lead sewage into, or wantonly to defile, the reservoirs 
and the streams feeding them. This protection is inadequate, as anything that happens to be on the gathering ground may be carried down into the reservoir in time of floods or heavy rains. When houses or farms exist on the gathering ground, serious impurities, such as the excreta from a typhoid case or the contents of a cesspool on a farmsteading, may be swept into the reservoir. It has been found difficult in practice to compel farmers living near a stream in a watershed to re-arrange their middens, cow-houses, etc. The diversion of sewage from farms by drains is scarcely an adequate protection. Wyrell (1) points out that the gathering ground is frequently not under the sanitary jurisdiction of the town owning the waterworks, but is under the perfunctory care of the rural sanitary authority. The Swansea Urban Sanitary Authority has arrangements by which its inspectors report weekly on the condition of the farms on the catchment area, cases of infectious disease being notified by telephone.

It is now held by eminent engineers that in order to prevent pollution of the water supply from these gathering grounds, the entire area over which rain is collected must be owned by the authority responsible for the waterworks, and must be managed solely in the interest of the water consumers.

The opinion of Mr. Joseph Parry (2), long the engineer in charge of the Liverpool Waterworks, is as follows: "Notwithstanding the sparseness of the population in most of these areas, great difficulty is experienced in keeping the standard of purity of the water at the level demanded by modern hygiene. It is most undesirable that the water for domestic consumption should be polluted by human sewage; and rigorous methods should be adopted to protect the streams and rivers in the gathering grounds from contamination by pathogenic organisms. Efforts made to prevent fouling by putting in operation the provisions of the Public Health Acts, the Rivers Pollution Act, and the bye-laws of conservators have proved ineffective. In consequence of the inadequacy and failure of these statutory 
provisions and bye-laws, a considerable number of corporations have taken steps to become owners of their own watersheds." In 1903, 102,615 acres were known by Parry to have been compulsorily acquired by Act of Parliament, a figure considerably increased since that date. Manchester was the first corporation to acquire complete ownership of a catchment area, namely, that of Thirlmere; but the price paid for the land was exorbitant. The acquisition of Thirlmere was much opposed at the time, as it was foolishly supposed that the scenery would be affected by the necessary waterworks. The pipes and conduits are now covered by vegetation. Ruskin, maddened to extravagance by the disfigurement of nature by modern industrialism, held that as Manchester produced no art, no literature, it had taken "to steal and sell for a profit the waters of Thirlmere and clouds of Helvellyn." Birmingham has absolute ownership of part of the basin feeding the Elan and Claerwen. Liverpool owns all the Vyrnwy gathering ground. Leeds in 1896-1897 obtained special powers to purchase compulsorily farms on their catcliment area in the Washburn Valley. Unfortunately on a considerable number of gathering grounds in Britain habitations and farms have not been abolished, chiefly owing to the large sums necessary for their purchase by the corporations, who in such cases usually own only the reservoirs.

The question now arises in what way ought catchment areas to be utilised, as it is impossible to leave them barren and unprofitable. Parry says: "In order to reduce to a minimum the risks of polluting the water in a manner likely to produce disease, the first object must be to limit the resident population to the lowest number reasonably practicable. This cannot be accomplished if agricultural operations are allowed to be carried on in the ordinary way, for no really satisfactory measures can be devised for the disposal and treatment of the sewage of resident populations of farmers and labourers with their families, and the pollutions from shippons and farmyards, so as to permit of the effluents being discharged into the watercourses. 
Sheep-grazing is from the waterworks' point of view the least objectionable of farming pursuits. Grouse moors are still less objectionable, especially where the growth of peat is kept under proper control and suitable channels are cut for the water."

Sheep-grazing, though generally believed to be innocuous, is not without danger, as frequently the sheep die, and their dead bodies are found in the streams. In one gathering ground, in order to encourage early notice, the corporation offers $5 \mathrm{~s}$. each for the bodies of dead sheep that may be found. J. W. Hill of Cincinnati, who built many waterworks in the United States, criticised (3) severely the Edinburgh Water Trust for permitting sheep-grazing on the Talla watershed, and said it was a hazardous experiment. $\mathrm{He}$ instanced the occurrence in Switzerland and in the Rocky Mountains of epidemics of typhoid fever, due to the water supply being contaminated by cattle which grazed on the gathering ground. He objected to any occupation of the catchment area of a watershed by either man or animals. W. L. Strange (4) says: "All surface catchments are liable to pollution, for even in pastoral areas there is contamination from man, animals, and vegetation, and filtration is therefore necessary. Pathogenic germs multiply rapidly and one cannot depend on their easy destruction. Silt in drinking water taken from rivers in India gives rise to bowel complaints, due to numerous minute flakes of mica in the silt."

In the gathering grounds which supply water to New York and Boston, U.S.A., there are numerous dwellinghouses; and the American engineer Hazen says it is unnecessary to remove the population from a water catchment area if suitable precautions are taken. Dr. A. C. Houston writes to me in reference to this: "Hazen incurs serious responsibilities by such a statement. Everything turns on the perfected nature of the precautions, and certainly as a counsel of perfection an uninhabited area is most desirable. Still I am free to admit that by storage, filtration (5), and sterilisation the most impure water can be rendered safe for domestic use." The question of supply 
of water is not only a hygienic, but in some respects also an aesthetic one. People may drink turbid water and water with an unpleasant taste or smell for a time without perhaps any definite injury to health. The aim, however, must be always to secure a supply of drinking water that is not only free from infectious matter, but is also capable of being drunk with satisfaction.

There is one means by which water catchment areas can be effectually guarded against pollution and at the same time be put to profitable use, and that is afforestation. In considering the advisability of afforesting a watershed, it need not be assumed that the entire area should be covered with trees. Questions of aspect, depth and nature of soil, shelter from wind or exposure, must be taken into account in determining where and what to plant. It is probable that the proportion of any gathering ground that can be planted with advantage will be found to vary from 10 to 70 per cent of the total. It is well known that on sites above a certain altitude, varying with the latitude and with the exposure to the prevailing winds, and on undrained peat soil at any altitude, planting trees is always unprofitable and often impossible. Generally speaking, it may be laid down that on most catchment areas which attain over 1000 feet elevation, a combination of grazing and forestry must be resorted to. Only the lower zone and the sites with favourable soil are suitable for planting. The arguments for afforestation are cumulative. In an area planted with trees the water is conserved to a considerable extent. When heavy rain occurs, the run-off water is much lessened, as the rain, as fast as it falls, is absorbed and stored by the deep humus layer on the floor of the forest. A larger percentage of rain will reach the reservoirs from an area that has been afforested. The quality of the water will also be superior, as the soil on the hill slopes will be held together by the roots of the trees, and the destructive effects of heavy rains, in carrying down masses of clay and stones, will be prevented. Flood waters will also diminish to a great extent, and, in consequence, the reservoirs will not be 
silted up. At present, on our treeless catchment areas, as Mr. Margerison (6) pointed out, " the heads of great reservoirs are being very seriously and rapidly silted up, and some day they will cost an enormous sum for cleaning out. Where is the silt to be deposited so that it is not again quickly washed back? And what are those corporations to do with it who do not own the adjoining freeholds? Herein afforestation will prove beneficial. Plantations will prevent, or greatly minimise, silt-laden surface-water rushes by blocking them and by promoting percolation and filtration." It has been objected that wooded catchment areas may pollute the water supply on account of the enormous masses of dead leaves which decay on the watersheds, or are blown about and carried down by streams to rot in the reservoirs. The humus in the forest is, however, antagonistic to pathogenic bacteria, and the decayed leaves themselves are absolutely innocuous. In order to prevent the leaves being blown into the reservoir, a band of ground next the water may be planted with gorse and other small-leaved shrubs, which form traps for the leaves of the trees. A narrow belt of spruce trees, which have dense, small, evergreen leaves, is a more efficient screen for this purpose. Only a small part of the foliage of the spruce is shed annually, namely, the leaves on the oldest and innermost parts of the branches. These leaves, as they are shed, fall on the ground beneath and are not blown to a distance. The falling leaves of oak, beech, ash, and other broad-leaved trees are blown to considerable distances by the wind, and, in the absence of a screen of spruce, may constitute somewhat objectionable litter in the water of the reservoir.

To sum up, the effect of trees on the yield and quantity of the water supply collected on upland areas cannot be otherwise than beneficial. In the U.S. Year-Book of Department of Agriculture, 1902, it is laid down: " A forest furnishes the best possible cover for watersheds of storage reservoirs. For this reason fully as much as the financial one, several water companies are planting extensively in the Eastern States, especially in Massachusetts and Connecticut." 
Newark (New Jersey) has adopted the policy of buying its water catchment area, with remarkable results, according to the engineer, Mr. R. Sherrerd. Of the total area of the watershed-64 square miles-Newark City now owns 43 square miles, and the population on the watershed has been reduced from 35 or 40 per square mile to 16 per square mile. Other measures taken have been demolition of houses, locking lavatories of trains in transit through the watershed, and patrol inspection. The bacteria per cubic $\mathrm{cm}$. of water diminished from 1100 in 1902 to 690 in 1910 and 510 in 1915 . The number of typhoid cases also decreased rapidly. In 1900 , when 93 per cent of the watershed was privately owned, there were 130 cases of typhoid per 100,000 inhabitants. In 1905, when 80 per cent of the watershed was privately owned, the typhoid cases sank to 80 per 100,000 . In 1910 , with 56 per cent private ownership, the typhoid rate was 52 per 100,000 ; and in 1915 , with 35 per cent private ownership, the typhoid rate was only 28 per 100,000 . The example of Newark in obtaining ownership of its water catchment area is likely to lead to similar action by other towns in the United States. Mr Sherrerd says: "The ultimate object of the city of Newark is not only to protect the consumers of water, but also to convert this part of New Jersey into a great municipal park."

In this connection it will be of interest to quote a very careful statement, made in Journal of Forestry, December 1917, p. 958, by Mr. Philip T. Coolidge, on the protection of water supplies in the United States.

"The acquisition of forest lands to protect water supplies is not clearly exemplified in any particular State, although the need of such protection is one of the arguments most frequently urged as a reason for public ownership. It is a fact that both municipal water supply corporations and municipalities themselves have generally found that actual ownership rather than regulation is necessary to prevent contamination of water supplies used for domestic purposes. It has been found that satisfactory policing of the water- 
sheds which supply potable waters can be secured only under direct ownership by the public or private interest which is vitally concerned. The obvious fact has also been found to be true that woodland rather than farm land or pasture affords the most effective safeguard against discoloration of water by eroded soil particles and against contamination by the germs of contagious diseases. It is interesting to note that on lands owned by water supply corporations, both public and private, intensive and very interesting sylvicultural measures have proven practical, because the project of forest production is free of any debit for the value of the land, that value being charged against the primary purpose for which the land is owned, namely, water production. As with lands needed for purposes of recreation, public acquisition of lands actually required to protect waters used for domestic purposes is desirable. In every case, however, the cause of sound democratic government demands that the necessity for the purchases be accurately determined and clearly understood by the body politic."

The aggregate amount of land in the water catchment areas all over this country is immense. Parry, in 1903, estimated the total area of the gathering grounds in Great Britain and Ireland from which supplies are collected for waterworks purposes to be almost 576,000 acres, irrespective of the watersheds contributing to rivers from which supplies are taken by pumping. These gathering grounds are either owned already, or should be purchased compulsorily by the corporations deriving their water supplies from them. Probably 100,000 to 200,000 acres could be afforested to the great advantage of the State. I need not enter here into the arguments for establishing a timber reserve in the country. These arguments have convinced all who have studied the subject, whether foresters, landowners, officials, or economists. The main difficulty of afforestation on a large scale in England lies in the necessity for the acquisition of the land by some corporation or State authority, who would be bound to 
carry out the work on the only lines that would ensure success, namely, the planting to be spread over a term of years, to be uninterrupted, and to be carried out in large blocks, in no case of less than 500 acres each. It will be difficult to induce private landowners to undertake, out of their diminished incomes, afforestation schemes on the large and continuous scale that is essential to success.

In the case of water catchment areas belonging to corporations, the question of continuous ownership is solved; and the agreement entered into on 18th August 1914 by the Liverpool Corporation with the Development Commissioners is a workable financial scheme that can be adopted generally. The Treasury provides the money necessary for planting, while the Corporation gives the land and pays the recurring annual expenses of management and taxes. In this partnership the produce of the forest will be ultimately divided between the two parties in the proportion of the capital invested by each. In this way the profit or loss accruing from the plantation will be fairly shared between the State and the Corporation. Afforestation should be imposed as a necessary duty on all the water authorities who obtain their supply from gathering grounds; in other words, each corporation ought to be compelled to carry out a planting scheme as soon as the Government shall issue a loan for the initial expenses of planting. The Forestry Board, that we hope to see established on the conclusion of peace, would prepare a working plan in each case, which ought to be systematically carried out, careful records being made of expenses and receipts.

Since this was written the Forestry Sub-Committee of the Reconstruction Committee have issued their Report, and have made a very definite pronouncement concerning the areas from which water supplies are collected by local authorities. "We consider it should be an invariable rule that on catchment areas all land which will produce a crop of marketable timber should be afforested. Many of the corporations are still engaged in meeting the capital outlay which their water supply systems necessitated, and for that 
reason are unwilling to place further burdens on the present for the benefit of future generations. We have little doubt that when the necessity of increasing our timber supplies has been explained to local authorities, much greater activity in systematic planting will be displayed, but in cases where they are still unwilling or unable to plant without assistance, local authorities should be eligible to receive all or any of the forms of assistance to which we refer." Two methods of assisting local authorities in municipal afforestation are then proposed:

(1) Proceeds-sharing. - "The State would provide the cost of planting and general supervision, and would lay down the working plan; the landowner (local authority) would provide the land and the cost of local management. Accounts would be kept of the annual contributions made by each party, and on the basis of these, reckoned up at compound interest, the annual receipts would be divided. This method seems rather complicated, as the ratio determining the division of proceeds would vary from year to year, but no doubt a simple method of crediting proceeds during the early years and arriving at a fair average ratio as the basis of calculation when the woods become fully productive could be mutually agreed upon."

(2) Assistance by Grants.-Grants up to $£ 2$ per acre towards the cost of planting conifers and up to $£ 4$ per acre towards the cost of planting hard woods are recommended, the following conditions being imposed: First, the area to be planted and the working plan must be approved by the Forest Authority and adhered to. Secondly, a minimum area to be planted at a minimum rate per annum, namely, at least 100 acres to be afforested and at least 10 acres planted up each year. Thirdly, the Forest Authority must be satisfied that the planting and subsequent care of the trees will be under adequately skilled management. Fourthly, the grant to be refunded with interest if the preceding conditions are not fulfilled.

Mr. Parry, at a meeting of the British Waterworks Association, 4th October 1918, preferred, under the con- 
ditions suggested, the method of assistance by grants, but was of opinion that the amount of grant per acre should be higher. He considered the proceeds-sharing scheme proposed in the Report to be less favourable than the Liverpool agreement referred to above, and to be surrounded by conditions which he would not advise any local authority to accept. In his opinion it would be a partnership with all the power and authority in the hands of one partner. Preferably the Forest Authority should be allowed to take over the whole business and pay the local authority a fair rent for the use of the land.

Various subsidiary arguments may be adduced in favour of planting these gathering grounds. Water power will be available, by which the successful working of the forest may be greatly helped. Saw-mills and wood-working machinery, driven directly by water power or by electric motors, would contribute to the profitable utilisation of the trees by the conversion of the timber to marketable sizes and by the production of wood pulp, matches, wooden implements, and other articles. At the end of the war, when large numbers of soldiers will be disbanded, immediate work would be found for men accustomed to rural labour if Corporations were called upon to begin at once the afforestation of their water catchment areas. Planting work is carried out in winter, when labour is less needed in building and other trades. It is supposed to be the intention of the Government to proceed at once with large afforestation schemes as soon as peace is declared; but the acquisition of the necessary land in sufficiently large blocks from private owners will take up much time in preliminary surveys and negotiations. No scheme sufficiently attractive to induce private landowners to co-operate vigorously in the planting of large tracts has yet been devised. In the case of land owned by Corporations there need arise no difficulty in starting this useful national work and establishing as soon as possible a timber reserve in these islands.

Mr. George Baxter, C.E., says that the main difficulty at present in Scotland is the want of powers by the Corporations 
to acquire the land on their water catchment areas at a fair value. The Lintrathen watershed, from which Dundee takes most of its water supply, is 22,000 acres in extent; but only 1000 acres have been purchased by the Dundee Water Commissioners, and of this 200 acres have been successfully planted. As 8700 acres in the gathering ground are below 1000 feet elevation, it is probable that a large forest might be profitably created at Lintrathen. The great difficulty lies in the exorbitant price that has been paid by Corporations for land compulsorily acquired. Mr. Baxter (7) urges that "the burden of an extensive afforestation scheme can only be equitably adjusted if State-aided. Government aid need not necessarily be wholly in the shape of direct financial assistance. Let us have a compulsory system of land purchase for waterworks purposes or afforestation purposes by local authorities, under which such land may be obtained at something like its market value instead of the present system, through the operation of which communities are called upon to pay such high prices."

The exorbitant prices paid by municipalities to landowners for waterworks sites and the like seem to be in many cases grossly unfair. This is due in part to the heavy costs of arbitration, and in part to the excessive sums awarded by arbiters under what Mr. James Watson(8) calls that intangible excrescence to the Land Clauses Consolidation Act known as 'special adaptability.' In England, Ireland, and Scotland "the claims set up under this head for land good, bad, or indifferent (if it had to be acquired under statutory powers for waterworks) were such that land instantly appreciated to ten or twenty times its agricultural value if needed for waterworks on the grounds of the ill-defined pleas of 'special adaptability." "

Value for 'special adaptability' seems to have been first claimed in the arbitration between the Countess Ossalinski and the Manchester Corporation in regard to land around Thirlmere. The award which was given, being about 120 years' purchase on the rental of the land and residence, was 
taken on appeal before the High Court. The Judges held that "the arbitrator in his award had justly taken into account the enhanced value of the land by reason of the water that might be collected, diverted, and impounded upon it, and also by reason of its natural and peculiar adaptation for the construction of a reservoir."

The following are examples of the remarkable awards which have been based upon the decision in this case :

The Swansea Corporation took, under an Act of Parliament, 152 acres for a reservoir out of a sheep farm of 5000 acres, which had been recently bought at auction for $£ 11,500$. The award made for special adaptability ( $£ 20$ per acre), in respect of the 152 acres and for 'easements,' was $£ 12,370$, being more than the cost of the whole farm of 5000 acres sold by auction as an ordinary hill farm.

Two acres of moorland were acquired by the Middle Ward District Committee of Lanarkshire for the Shotts Reservoir. The land was valued by a competent valuator at $£ 326$. An award was made of $£ 465$, but the Corporation were obliged to pay in addition $£ 28$ as interest and $£ 219$ for the costs of arbitration, making $£ 712$ in all-in other words, more than twice as much as the just value of the land.

The Glasgow Corporation, when raising the level of Loch Arklet, were compelled to pay $£ 19,115$ in respect of 381 acres of rough heather moorland, of which they only acquired freehold of 17 acres. In addition to this sum, the Corporation had to pay $£ 4700$ for legal expenses, $£ 3500$ for new roads, etc., and $£ 4700$ for the right to store water, etc., or $£ 31,900$ in all. This seems monstrous, in view of the fact that the 381 acres were practically of little or no value, being part of 11,500 acres of hill pasture, the gross rent of which was $£ 700$, worth then at 25 years' purchase only $£ 17,500$. The real value of the 381 acres would seem to have been less than $£ 600$, yet $£ 31,900$ was extorted.

The Royal Commission (9) on Housing in Scotland, after hearing evidence on this question, came to two clear and 
definite conclusions; first, that the traditions and customs which lave in the past surrounded arbitrations have resulted in excessive awards and excessive costs of arbitration; and second, that these excessive awards and costs have paralysed the efforts of local authorities in their attempts to administer Acts framed in the interests of public health and otherwise for the general good.

The first report of the Committee appointed by the Ministry of Reconstruction to deal with the law and practice relating to the acquisition and valuation of land for public purposes was published as Blue Book, Cd. 8998, in January 1918. Its main recommendations are concerned with the simplification of the procedure for compulsory acquisition of land. The Committee acknowledge that " the costs of procedure under the Land Clauses Acts are not infrequently so great as to neutralise financially the advantage of possessing such powers," and they instance cases of exorbitant prices demanded for land from the Admiralty and other Government Departments. "Under the present system, public authorities may well prefer to pay any figure up to double the fair value of the land rather than face the delays and expenses of compulsory acquisition." The valuation of land for public purposes is fully dealt with in the second report by this Committee.

The history of the afforestation of the various catchment areas throughout the country shows in how fitful a manner and on how small a scale this important civic and national work has been carried out in past years. This furnishes a strong argument for compulsion on the lines suggested above. Mr. Parry writes to me: "I attach great importance to the agreement between the Government and the Liverpool Corporation, because it ensures the steady working out of a planting scheme over a large area under permanent conditions of supervision and progress. Any scheme undertaken by a Municipal Corporation, unaided and uncontrolled, is liable to interruption through the changes constantly taking place in the composition of Councils; and there is also considerable danger of mismanagement." 
The Departmental Committee on British Forestry, which reported in 1902, drew the attention of local authorities, deriving their water supplies from gathering grounds owned by them, to the advantage and profits to be derived from planting the catchment areas with trees, not only to contribute to the retention of the rain and assist in regulating the water supply, but to help to purify the water and at the same time yield a regular income on the capital expended. In connection with this report the Local Government Board obtained a return in 1903, showing which of the local authorities owning waterworks had acquired the freehold or long leasehold of the catchment areas from which their water supplies were derived. This return, which was not published, showed that at that time 5 joint boards and 74 town and district councils in England and Wales owned or had a long lease of a part or all of their gathering grounds (10).

The Journal of the Board of Agriculture, xi. 468 (November 1904), in an article on this subject, points out that such catchment areas must "be placed under the control of a competent forester, and inasmuch as they will be under corporate control, and less subject to change of management than land owned by private individuals, there is no reason why they should not also ultimately serve as demonstration forests and be available for the instruction of students. For example, the catchment areas of Liverpool and Birmingham waterworks situated in Wales, within reach of University Colleges possessing agricultural departments, could, with the consent of the Corporations concerned, be used for these purposes; and a similar arrangement might be made with regard to certain areas in Yorkshire within reach of the University of Leeds."

In the same Journal tables were published showing the acreage and other particulars of the gathering grounds in Great Britain, which in 1904 were held as freehold or on long lease by local authorities. These tables, based on returns made in that year to the Board of Agriculture by the various municipalities, were confessedly incomplete, 
and in certain cases inaccurate. Returus from only 47 authorities were given. Important areas, such as the Liverpool Corporation's catchment area of 10,000 acres at Rivington, were onitted. The figures excluded land subject to common rights, small areas of freehold, and certain areas which the local authorities reported as being too exposed for planting. Nevertheless, the fact was disclosed that over 100,000 acres of catchment areas were owned or held on long lease by local authorities. The tables summarised indicated for 1904 :

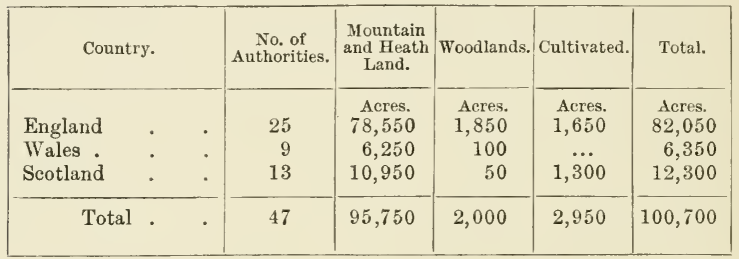

In the Final Report of the Reconstruction Forestry Sub-Committee (Cd. 8881 of 1918, p. 93) it is stated that the Glasgow Corporation's areas at Loch Katrine and Gorbals should be added to the list as being owned by the local authority. This is incorrect, as the ownership of these areas still remains in private hands, and the Glasgow Corporation have no rights to make plantations upon them.

The Board of Agriculture again, in 1909, made an inquiry concerning the amount of planting that had since been carried out. The result of this inquiry showed (11) that in the majority of cases, even where local authorities were in possession of the freehold or had long leases of their catchment areas, little progress had as yet been made. In a few cases, on the other hand, the work had been taken up seriously, and planting was being done on a systematic plan. Reports received from fourteen local authorities indicated that altogether some 2200 acres had been planted, and that schemes were on foot for planting a similar area during the ensuing five years. Leeds, Liver- 
pool, Birmingham, Manchester, and Torquay had planted on a considerable scale; while Oldham, Llandudno, Bolton, Darwen, Bury, Cardiff, Derwent River Valley Board, and Plymouth had each planted a few acres. It was evident that with the exception of three or four of the larger municipalities the matter had been half-heartedly taken up. The cost of the work had also been very high in most cases, and there were indications that with one or two exceptions it had been indifferently carried out. Some of the planting had been hastily undertaken with a view to finding employment for men thrown out of work during the trade depression of the years 1908 and 1909 , and generally without proper advice or expert supervision.

The Reconstruction Report says that "complete figures are not available of the total area of land held by Local Authorities in the catchment areas of their water supplies. The total area is considerable, and, moreover, is increasing steadily. It is not possible to say definitely in the absence of a survey what proportion of the total area held by Local Authorities is afforestable. A survey made by the Board of Agriculture of the Birmingham Corporation's land in Wales disclosed 6000 acres of suitable land. After making deductions for altitude and exposure, unsuitable soil, etc., it would probably be found that the total acreage of water catchment areas fit for afforestation in Great Britain is not less than 50,000 acres, and may be considerably more."

This estimate is a moderate one; more likely 80,000 acres of municipally owned lands are available for planting in the British Isles. How important these areas are in the aggregate will be shown in the three concluding chapters of this book, where detailed descriptions are given in geographical order of nearly all the gathering grounds of water supplies in England and Wales, Scotland, and Ireland. The total extent in 1918 of the gathering grounds in Great Britain and Ireland, summarised from the information given in these three chapters, is shown in the following table : 


\begin{tabular}{|c|c|c|c|c|c|}
\hline \multirow{2}{*}{ Country. } & \multicolumn{3}{|c|}{$\begin{array}{l}\text { Total Extent of } \\
\text { Gathering Grounds. }\end{array}$} & \multicolumn{2}{|c|}{$\begin{array}{l}\text { Extent owned by } \\
\text { Local Authorities. }\end{array}$} \\
\hline & $\begin{array}{c}\text { Local } \\
\text { Authorities. }\end{array}$ & $\begin{array}{c}\text { Companies, } \\
\text { ete. }\end{array}$ & Acres. & $\begin{array}{c}\text { Local } \\
\text { Authorities. }\end{array}$ & Acres. \\
\hline England and Wales & 127 & 14 & 591,336 & $64 t$ & 140,305 \\
\hline Scotland . & 78 & $\ldots$ & 243,624 & 16 & 27,829 \\
\hline Ireland & 46 & $1 *$ & 93,835 & 9 & 15,282 \\
\hline Total. & 251 & 15 & 928,795 & $89+$ & 183,416 \\
\hline
\end{tabular}

* Water supply owned by private landowner.

+ One Company is included in these totals.

In conclusion it is encouraging to know that the few Corporations who have been in earnest are satisfied with the results of their afforestation schemes. Liverpool, Leeds, Birmingham, and Manchester have all done notable work, an account of which may fittingly conclude the present chapter.

Liverpool.-The most important work of this kind is probably the systematic afforestation that has been carried out during recent years by the Liverpool Corporation on their catchment areas at Vyrnwy and Rivington (12).

The Vyrnwy gathering ground (13), with a total area of 22,742 acres, is situated in the valley of the Piver Vyrnwy, near its source in Montgomeryshire, and ranges in elevation from 780 to 2000 feet, with an average annual rainfall of 70 inches. The artificial reservoir, known as Lake Vyrnwy, covers 1121 acres, and three catchment areas drain into it, namely, the River Vyrnwy area, 18,000 acres, the Cownwy stream area, 3092 acres, and the Marchnant stream area, 1650 acres, making a total of 22,742 acres, practically all of which has now been acquired by the Liverpool Corporation; but there are on the Vyrnwy area some disputed boundaries near the tops of the watershed lines not yet settled. In the Cownwy and Marchnant areas the Corporation have, to suit the convenience of the vendor, taken over some farms, which extend beyond the catchment areas. The land, in great 
part let to tenants, is mostly occupied by sheep, but the farms are gradually being acquired as the tenancies expire; and ultimately there will be no houses on the watershed, and nothing but forest around the lake and rivers.

When the Corporation bought the land, there were 170 acres of old woods on the Vyrnwy area. Planting operations on commercial principles were commenced in 1897, in accordance with a report and plan made by Prof. W. R. Fisher in the preceding year. By April 1903 there were over 600 acres of old and new plantations. A saw-mill was erected, and nurseries were established, which enabled the subsequent planting to be carried out at a more rapid rate. The total area of the plantations made up to October 1918 was 1383 acres, situated between 825 and 1500 feet elevation, no less than $3,600,000$ young trees having been employed, all of which are growing splendidly. The main species used have been larch, Douglas fir, spruce, silver fir, Scots pine, Corsican pine, and beech, with some ash, sycamore, oak, and alder. The larch and Douglas fir show remarkable vigour of growth at the present time; and ultimately there will be a magnificent forest of 5000 acres around Lake Vyrnwy.

On 18th August 1914 an agreement was come to between the Treasury and the Corporation, on lines laid down by the Development Commissioners, for the afforestation of 5000 acres on the Vyrnwy area. The Treasury were to advance to the Corporation from the Development Fund on loan $£ 5$ per acre, as required for planting, up to a limit of $£ 25,000$; while the Corporation were to pay to the Development Fund the price of one-half of the produce utilised or sold from the area afforested by means of the loan, such payment to be made as and when the produce is utilised or sold.

Mr. Parry, in a paper read at the annual meeting of the British Waterworks Association, 4th October 1918, says:

"Under the agreement, as ultimately settled, the Corporation have undertaken to plant an area of 4000 acres around Lake Vyrnwy, in blocks of approximately 200 acres 


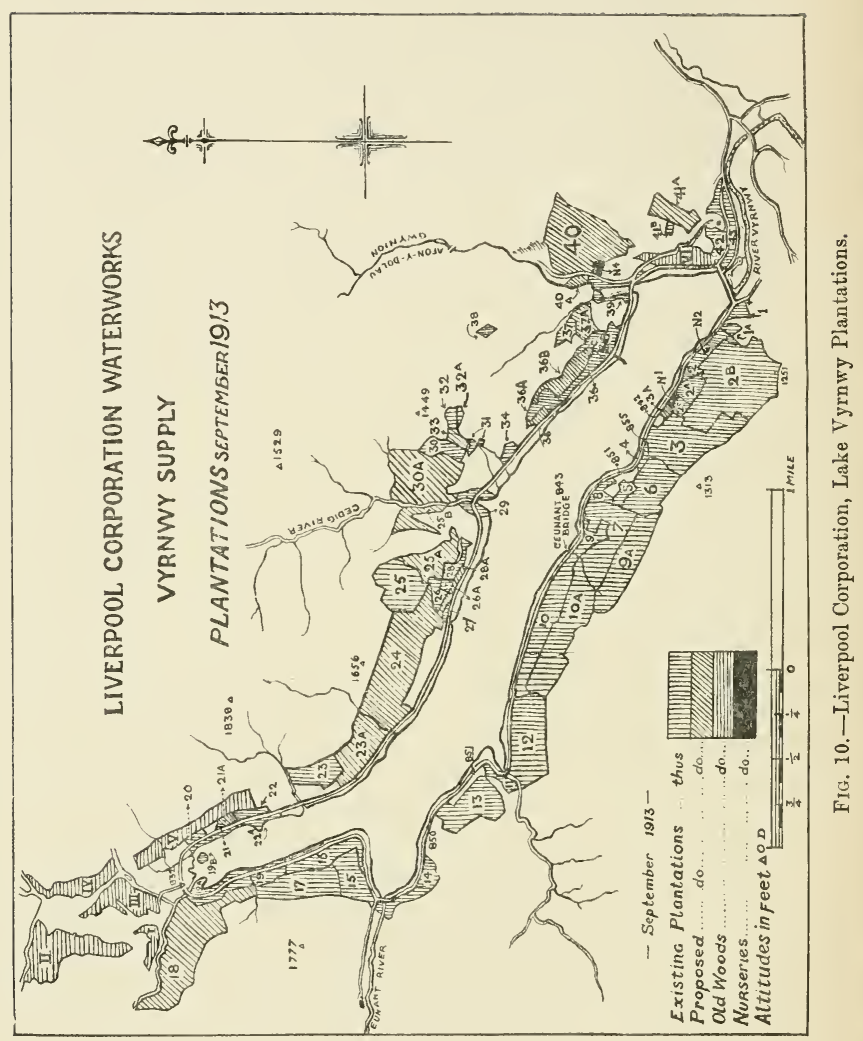


each year, thus extending the completion of the scheme over a period of twenty years. A working plan was prepared and approved of by Government on which these twenty sections are marked out, but there is provision for deviations being made if required by circumstances. The Government contribute a sum per acre which is intended to cover approximately the actual cost of planting. Also they contribute a specified allowance per acre in respect of maintenance. Payment is made by the Treasury in advance at the beginning of each planting season, after inspection and approval of the previous year's planting by an expert from the Forestry Department. In consideration of these advances, the Corporation have to pay to the Treasury a sum equal to one-half of the net value of all timber, saplings, thinnings, and other products resulting from the joint operations. There is also an arbitration clause in the event of differences arising between the Corporation and the Board of Agriculture or Treasury. Briefly, the arrangement is, that the Corporation provide the land, plant the trees, and sell the products. The Government pay, in advance, the cost of planting. The profits are divided equally between the two parties."

Mr. Parry, to whom I am much indebted for information about the Liverpool catchment areas, attaches "great importance to the agreement between the Government and the Corporation, chiefly because it ensures the working out of a planting scheme over a large area. Any scheme undertaken by a Municipal Corporation, unaided and uncontrolled, is liable to interruption through the changes constantly taking place in the composition of Councils; and there is also considerable danger of mismanagement."

The adoption of this scheme involved the taking in hand, during twenty years, of 9 farms on the Vyrnwy area, from which the Corporation now derive a gross rental of $£ 583$, and a net rental (allowing for repairs) of $£ 498$. These farms cover 9645 acres, including grouse moors also let for sporting, not suitable for planting. The value of the sporting would be considerably increased by the removal 
of the sheep; and the closing of the farmsteads would remove an objectionable source of pollution. Some portions of the Marchnant area, recently purchased, would also be included in the planting area. There are six farmsteads on the Marchnant area, three of which have been strongly condemned by the Medical Officer of Health in consequence of the pollutions caused by their proximity to important streams.

Mr. Parry, in the paper quoted above, states: "If it had not been for the war, the total area planted under the Government scheme would have been 1000 acres, representing about 2,250,000 trees. The occurrence of the war, with the resulting shortage of labour and cost of fencing materials, has, however, made it impossible to carry out the full intention of the agreement, and, with the concurrence of the Board of Agriculture, the number of acres actually planted has been little more than one-half the area marked on the plan. During the years 1897-1913, the Corporation planted altogether $2,500,000$ trees on 884 acres. The number of trees planted to date (October 1918) under the partnership agreement with Government is $1,101,891$, and the number of acres 499 , thus making a grand total of $3,600,000$ trees and 1383 acres."

The writer visited Lake Vyrnwy in September 1918, and was much impressed by the flourishing state of the plantations, which have been under the care of the head forester, Mr. J. Carsley, for the last twenty-five years. Some mature timber was felled during the war; and the following table, based on diagrams supplied by Mr. R. L. Robinson of the Board of Agriculture, shows the comparative growth of the various species in two of the older woods. 
Height, Growth of Sample Trees in Older Woods, Lake Vyrnwy.

(sh. =sheltered ; exp. =exposed.)

\begin{tabular}{|c|c|c|c|c|c|c|c|c|c|c|}
\hline \multirow[b]{2}{*}{$\begin{array}{l}\text { Elevation } \\
\text { in feet } \\
\text { Exposure } \\
\text { to wind. }\end{array}$} & \multicolumn{2}{|c|}{ Larch. } & \multicolumn{2}{|c|}{ Silver Fir. } & \multicolumn{2}{|c|}{ Spruce. } & 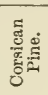 & 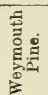 & 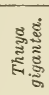 & 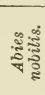 \\
\hline & $\begin{array}{l}865 \\
\text { sh. }\end{array}$ & $\begin{array}{l}900 \\
\text { exp. }\end{array}$ & $\begin{array}{l}900 \\
\text { sh. }\end{array}$ & $\begin{array}{l}900 \\
\text { exp. }\end{array}$ & $\begin{array}{c}865 \\
\text { sh. }\end{array}$ & $\begin{array}{l}900 \\
\text { exp. }\end{array}$ & $\begin{array}{l}925 \\
\exp .\end{array}$ & $\begin{array}{c}875 \\
\text { sh. }\end{array}$ & $\begin{array}{c}875 \\
\text { sh. }\end{array}$ & $\begin{array}{c}865 \\
\text { sh. }\end{array}$ \\
\hline
\end{tabular}

Height in FeEt corresponding to Various Ages.

\begin{tabular}{|c|c|c|c|c|c|c|c|c|c|c|}
\hline \multirow{2}{*}{$\frac{\text { Years of Age. }}{8}$} & \multicolumn{2}{|c|}{ Larch. } & \multicolumn{2}{|c|}{ Silver Fir. } & \multicolumn{2}{|c|}{ Spruce. } & \multirow{2}{*}{ 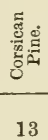 } & \multirow{2}{*}{ 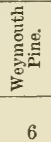 } & \multirow{2}{*}{ 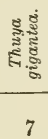 } & \multirow{2}{*}{$\frac{13}{13}$} \\
\hline & 21 & 12 & 7 & 5 & 14 & 8 & & & & \\
\hline 12 & 32 & 18 & 13 & 10 & 25 & 13 & 22 & 12 & 14 & 22 \\
\hline 22 & 48 & 30 & 29 & 25 & 46 & 31 & 36 & 31 & 32 & 46 \\
\hline 29 & 62 & 42 & 42 & 36 & 63 & 45 & 45 & 41 & 40 & 57 \\
\hline 35 & 70 & 50 & 54 & 45 & 77 & 53 & 54 & 47 & 52 & 66 \\
\hline 38 & $\ldots$ & $\ldots$ & $\ldots$ & $\ldots$ & $\ldots$ & $\ldots$ & $\ldots$ & $\ldots$ & 56 & $\ldots$ \\
\hline 40 & $\ldots$ & $\ldots$ & $\ldots$ & $\ldots$ & $\ldots$ & 58 & .. & $\ldots$ & $\ldots$ & $\ldots$ \\
\hline 41 & $\ldots$ & $\ldots$ & $\ldots$ & $\ldots$ & $\ldots$ & $\ldots$ & 61 & $\ldots$ & $\ldots$ & $\ldots$ \\
\hline 43 & $\ldots$ & $\ldots$ & 66 & 52 & $\ldots$ & $\ldots$ & $\ldots$ & $\ldots$ & $\ldots$ & $\ldots$ \\
\hline 45 & $\ldots$ & 62 & $\ldots$ & $\ldots$ & $\ldots$ & $\ldots$ & $\ldots$ & $\ldots$ & $\ldots$ & $\ldots$ \\
\hline
\end{tabular}

Timber Volume (Quarter Girth) of each Sample Tree over Bark, Cubic Feet.

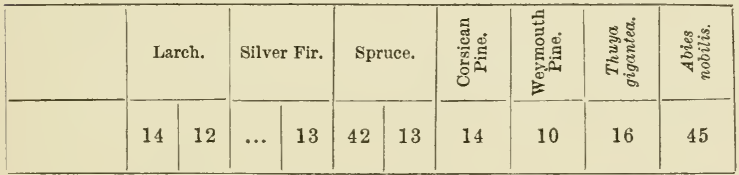

These measurements show the great value of European larch and spruce for the production of timber in the mountains of Central Wales. Corsican pine does well at high elevations; and plantations of this species made in 1906-1907 at 1300 feet above sea-level showed an average height of 10 feet in 1918 , with leading shoots of the current season about $1 \frac{1}{2}$ feet in length. The newer 
plantations made by the Corporation indicate that Douglas fir ought to bulk largely in the afforestation of mountain valleys. Various plots of Douglas fir showed the following growth: At 860 feet altitude, an average tree, 26 years planted, was 64 feet high by 2 feet 8 inches in girth; at 850 feet elevation, an average tree, 29 years planted, was 50 feet high by 3 feet 4 inches; at 840 feet elevation, two trees, 19 years planted, were 43 feet by 2 feet and 52 feet by 2 feet 9 inches. At the high elevation of 1200 feet, growth of Douglas fir was much checked by exposure to wind, the height, 20 years after planting, being about 25 feet. Sitka spruce has unluckily not been planted as yet in quantity at Lake Vyrnwy; but there are three trees of this species growing near the embankment at 850 feet elevation, which show remarkable vigour of growth. Planted 35 years ago, they are 70 feet in height, and average 5 feet 8 inches in girth. Near them are numerous self-sown seedlings, 4 to 12 inches high, which show that natural regeneration of this valuable tree may be looked for, provided that rabbits are excluded. Sitka spruce should be largely used in wettish places, and at high elevations. Japanese larch, 9 years planted, is about 22 feet high, and flourishes here. Scots pine, planted in 1899, averages only 15 feet high, and is of little value for the production of timber in comparison with larch, Douglas fir, and Sitka spruce. These three species are unquestionably the most profitable for the afforestation of large areas of mountain land.

The Rivington catchment area, 10,000 acres in extent, was purchased by the Liverpool Corporation in 1902 . It is situated on millstone grit, between 450 and 1498 feet elevation, and consists mainly of moorland and hill grazing. The population surrounding the area had been increasing rapidly, and was tending also to increase upon the watershed itself, so that it was becoming extremely difficult to prevent the streams from being polluted, especially by the farming operations of numerous small holders on the estate. To deal with this danger effectually the Corporation became owners of the property; and since then have got rid of a 
considerable number of small farmers, and greatly reduced the number of sheep on the area, thus lessening the risk of contamination of the streams. The Corporation also adopted a scheme of afforestation in 1904, with the view of keeping the water pure. By 1908 about 408 acres had been planted with $1,640,000$ trees. Smoke arising from the large manufacturing towns around Rivington caused some difficulty, as certain species failed to grow or ceased to thrive after a time. Beech and ash, however, were a success ; sycamore throve moderately; and Corsican pine and Douglas fir did well in certain situations. Larch proved a failure.

The growth of trees on the Rivington area has not been entirely successful, as some years ago a plague of voles did great damage. The smoke nuisance has gradually increased, and for the last four or five years forestry operations have been confined to filling up vacancies. The total area of the plantations, however, amounted on 30 th June 1916 to 1300 acres, situated between 450 and 1100 feet elevation. Beech, spruce, sycamore, ash, alder, Corsican pine, and oak were the main species planted, $3,404,866$ young trees being used.

The Liverpool Corporation have not entered into any agreement with the Government in regard to the afforestation of the Rivington area. The subject was discussed in 1912, when a joint scheme for planting the Lancashire gathering grounds of the Liverpool and Bolton Corporations was proposed; but the matter dropped.

Manchester owns two catchment areas, that of Lake Thirlmere in Cumberland, and the Longdendale Valley in Cheshire and Derbyshire.

The natural catchment area of Lake Thirlmere is 7400 acres, but water from a further area of 3600 acres was diverted into the lake, so that the total catchment area is 11,000 acres, all owned by the Manchester Corporation. This ranges in elevation from 533 feet, the natural level of the lake, up to 3118 feet, the surnmit of Helvellyn. The geological formation is Lower Silurian, the rock being near 
the surface. There is scarcely any peat, the water even in times of flood being very clear. The mountains surrounding the lake are very precipitous, and are used as sheep pastures. At present there are only two farmsteads, used for sheep farms, within the catchment area, and very little ploughing is done; but the fells are still let as sheep grazing. The annual rainfall is heavy, varying in wet years between 100 inches in the valley and 137 inches in the hills on the west side, and in dry years between about 60 and 80 inches in the same places. From the almost entire absence of peat and the precipitous and rocky elevation of the Thirlmere area, the yield of water is largely in excess of that obtained from other watersheds in this country. The lake in its natural state covered 328 acres, and had a normal level of 533 feet above the sea, but a masonry dam constructed across the outlet has raised the level, and increased the area to 500 acres (14).

When the Corporation acquired Thirlmere (Fig. 14) there were about 283 acres of old woods, consisting of sessile oak, ash, beech, and alder, with scattered larch plantations. The latter were splendid in growth, some of the trees attaining 100 feet in height and 8 to 10 feet in girth, and there was little disease. These woods were maintained by the Waterworks Committee, who started nurseries and made new plantations, which amounted by the end of 1907 to 389 acres. At that time the entire area consisted of lake, 500 acres; farms, 1500 acres; fell (high mountain grazing), 5000 acres; intake (land enclosed from the fell, but for which additional rent is not paid by the occupiers), 3000 acres; old woods and new plantations, 672 acres; proposed plantations, 328 acres. Of the fell about half, that on the east side, is common land dependent on the farms. The other half, on the west of the lake, is the absolute property of the Corporation. Prof. W. R. Fisher (15) drew up a working plan and report on the woodlands around Thirlmere in the beginning of 1908. A trained forester was appointed, and regular planting was taken in hand, which has continued up to the present time, the area of the plantations made from 1908 till February 1917 
being 540 acres. There are thus at present on the area 283 acres of old woods and 929 acres of young plantations, 1212 acres in all. The plantations have been successful

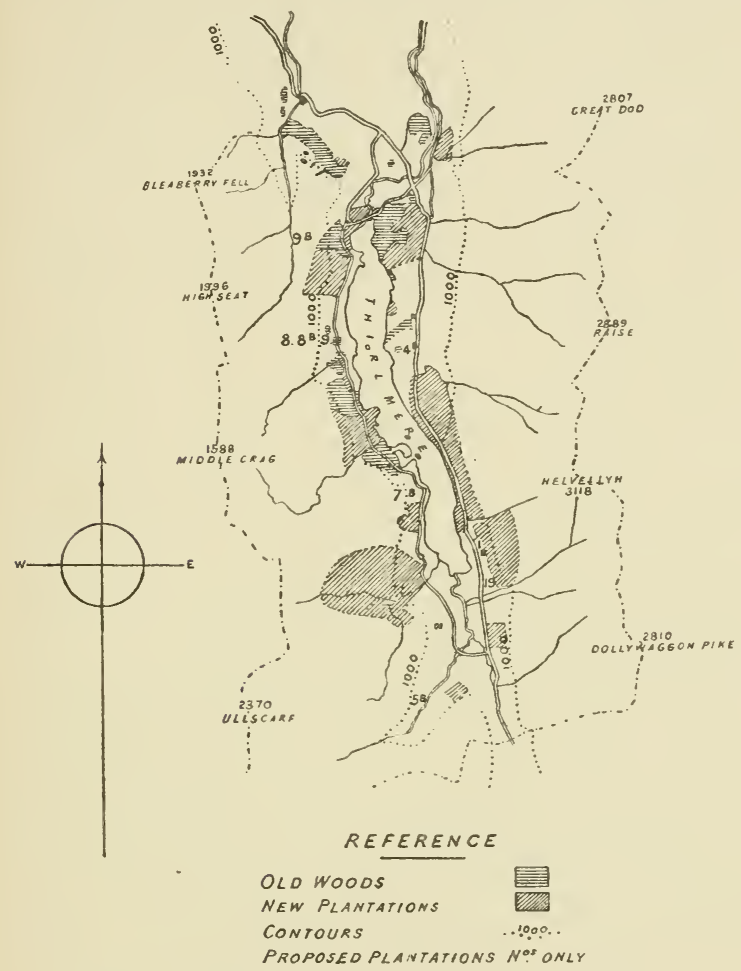

FIG. 11.-Manchester Corporation, Thirlmere Plantations.

from a commercial point of view, and have greatly improved the beauty of the landscape.

The plantations are mostly near the lake, the newer ones 
being on the intake on the lower slopes between the valley and the fell, and in some places ascend up to 1500 feet elevation. The reclamation of the moorland to pasture would set free a larger area of intake for tree-planting. Both Prof. Fisher's report, published in Manchester in 1908, and an article by A. P. Grenfell in the Quarterly Journal of Forestry, iii. 21 (1909), may be consulted on this interesting and successful attempt at afforestation of a mountain watershed.

The forester, Mr. A. W. B. Edwards, who wrote an article in Trans. Roy. Scot. Arbor. Soc. xxvi. 37-45 (1912), on the methods of planting adopted at high elevations on the Thirlmere area, recommends autumn planting as a rule, except for wet ground or peat, which should be planted in spring. He strongly advocates the use of small plants, preferably 2-year seedlings. In planting steep hillsides he uses the mattock (Fig. 15), commencing at the top of the intended plantation and working to the bottom (16). He uses larch mixed with beech as the main crop except in exposed sites; and plants a belt of pines, generally a mixture of Scots, Corsican, and Austrian pines, six or eight rows wide, all round the plantation, and also on any outstanding ridges and crags; and at the higher levels mixes the larch alternately with pines, passing gradually into pure larch as he descends to the 1000 feet contour. Though strongly in favour of Sitka spruce for high and exposed altitudes, he writes on 15th December 1918 that this species has only been used till now for filling vacancies. It has done well, some trees being about 15 feet high. Douglas fir, planted in the spring of 1908 , now averages 30 feet in height, while Corsican pine, planted alongside at the same time, is about 10 feet high. Abies grandis, recommended by Prof. Fisher, was not tried, as plants of it were too dear.

Longdendale Valley, the catchment area of the river Etherow and its tributaries in Cheshire and Derbyshire, is 19,300 acres in extent, of which about one-third or 6400 acres are owned by the Manchester Corporation. The area is situated in an elevated part of the Pennine range, and 
varies in altitude from 486 to 2060 feet elevation, with an average annual rainfall of 40 to 50 inches. Very little planting has been done in this catchment area, the total area planted being about 120 acres on the Cheshire side and about 30 acres on the Derbyshire side of the valley. There are seven storage reservoirs: Woodhead, 782 feet elevation; Torside, 650 feet; Rhodes Wood, 574 feet; Vale House, 503 feet; Bottoms, 486 feet; Arnfield, 540 feet; and Hollingworth, 554 feet. The two latter reservoirs are to the west of Tintwistle. The water is passed through copper wire gauze strainers, but is not filtered. J. F. L. T. Bateman, History and Description of Manchester Waterworks, p. 152 (1884), gives an account, with map, of the Longdendale water catchment area.

Leeds obtains its water supply from the Washburn Valley, a tributary of the Wharfe, about eight miles west of Harrogate. As this district is now being afforested by the Corporation, it is interesting to know that it was formerly part of the Royal Forest of Knaresborough, which remained thickly wooded till the reign of Queen Elizabeth. Iron smelting was then extensively carried on, which resulted in the gradual destruction of the timber, so that by $1700 \mathrm{few}$ trees were left. The district was enclosed under Act of Parliament of 1770 , and some of the land was subsequently broken up and cultivated.

The Washburn Valley has a catchment area of 21,552 acres, consisting of two divisions. The lower division, 4505 acres, is reserved for compensation water, which is collected in the Lindley Wood reservoir at 299 feet altitude. The upper division, 17,047 acres, is reserved for domestic purposes, and has two reservoirs, Swinsty reservoir at 449 feet elevation and Fewston reservoir at 503 feet.

Between 1867 and 1900 Leeds Corporation acquired, out of the whole area, about 10,700 acres, which consist chiefly of gently sloping land on either side of the Washburn, descending from an upper limit of 900-1390 feet to the levels of the reservoirs, 299-449 feet. The geological 
formation is millstone grit underlying glacial clay with boulders; forming a soil wet in winter and very dry in summer. The soil is generally a sandy loam, warm and dry on the southern slopes, where much of the clay appears to have been denuded, and cold and stiff with the clay predominating on the northern slopes, while there is some peat at the high altitudes. The land may be roughly divided into two classes, grassland and moorland, the former occupying the lower reaches immediately surrounding the reservoirs, while moorland and poor pasture occupy the upper reaches. There are about 120 farms in the valley, nearly all small holdings of grass, with little arable land. In order to prevent any pollution from these farms, the Corporation decided in 1904 to reafforest part of the valley, with the primary object of purifying the water, and secondly, with the view of giving work to the unemployed in Leeds. For three seasons men drawn from the Unemployed Bureau were engaged in planting. Economic planting proved to be impossible with this class of labour; and since 1909 the work has been done with a permanent staff of ten men, with extra help during busy times. 30 to 40 acres of new land surrounding the reservoirs have been planted each year; and up to August 1914 about 835 acres had been planted with $3,400,000$ trees. In October 1918 the area of growing timber was "over 900 acres, and the results very good indeed" (17).

With regard to the use of the unemployed during three seasons, Mr. C. G. Henzell, Waterworks Engineer of Leeds, states (18) that the average cost of draining, fencing, planting, etc., was $£ 12$ per acre; but that the cost should not have been more than $£ 8$ per acre, the excess being due to the employment of inexperienced men. Much of the work was badly done, and the failures were quite 30 per cent. The men were not accustomed to spade work, and few were able to stand the rough weather. Any scheme of afforestation will undoubtedly afford employment to a considerable number of men, but planting trees is skilled work and requires preliminary training The great advantage of 
forestry work is that it is mainly done in winter, when the demand for ordinary agricultural labour is slack. A combination, in any part of the country, of afforestation and farming will provide continuous labour to the rural population, and automatically get rid of the unemployment problem.

A complete account of the Washburn Valley afforestation scheme by Mr. A. Pope, the forester in charge, appeared in Quarterly Journal of Forestry, viii. pp. 190-207 (1914), with map, now reproduced (Fig. 12), and should be read by those interested in planting on land of the varied character that is usually met with in upland gathering grounds.

The water in the Swinsty reservoir is connected by four mains with Eccup reservoir, south of Harewood Park, whence it is conveyed to filter beds at Weetwood, near Leeds.

In addition to the Washburn area, the Leeds Corporation have several other waterworks schemes, not yet completed, as follows :

Laver Valley, west of Ripon, catchment area of 7334 acres, of which 4000 acres have been acquired by the Corporation. It is proposed to build on this area two reservoirs, one at Laverton for compensation water, and another at Carlesmoor, a mile higher up the stream, for domestic supply.

Burn Valley, catchment area of 5886 acres, with a contemplated reservoir just below Colsterdale village, west of Masham.

Pott Beck Valley, catchment area of 4702 acres, with Leighton reservoir, now in course of construction. This area derives its supply from the lower part of the Pott Beck Valley, Grimes Gill, and Spruce Gill Beck, and is contiguous with the catchment area of Roundhill reservoir, belonging to Harrogate, which gets its water from the upper part of the Pott Beck Valley.

Birmingham has the largest watershed of all the Corporations, 45,כ562 acres, situated in the Elan and Claerwen valleys in Radnorshire and Breconshire. It ranges in altitude from 822 feet, the level of the Caban Coch reservoir, to 2115 feet, the average elevation being about 1350 
feet. The greater part of the area is open mountain pasture and moorland, not carrying more than one sheep to the acre. Geologically the area consists of Lower Silurian slates, grits, and conglomerates; and on some of the flatter tops of the hills peat occurs in places to a considerable depth. The catchment area is sparsely peopled, there being only 30 inhabited dwelling-houses in 1912, containing a population of perhaps 150 , or say 2 persons per square mile. The greater part of the area is commonable land, but the Corporation have secured the rights over most of the commons, and have purchased all freehold lands in order to be able to protect the water from pollution at its source. "These commons now carry about 24,000 sheep, and no cattle are allowed, so that the freedom of the water from animal contamination is beyond doubt." According to information supplied officially in July 1918, the Birmingham Corporation have acquired manorial rights over the whole area of 45,562 acres. The Corporation now own all the freeholds, 5263 acres, of which 878 acres are covered by reservoirs. The commons comprise 40,299 acres; and the Corporation have acquired common rights and rights of pasturage over 32,714 acres, leaving an area of 7585 acres, of which these rights are unpurchased or disputed.

The low-lying valleys, which formerly served as wintering ground for sheep with farm steadings, etc., became useless for this purpose as soon as they were submerged and occupied by reservoirs. It was found necessary to provide shelter for flocks; and the Corporation decided that the best form of shelter would be the putting down of plantations in suitable places. Certain sites were selected, and by 1909 nine separate plantations, with an area of 410 acres, between 900 and 1500 feet elevation had been made and were reported to be very flourishing. The work here was done by contract, costing according to elevation from $£ 3: 13: 7$ to $£ 4: 18: 9$ per acre, exclusive of fencing and clearing the site. These items raised the total average cost to $£ 7: 10$ s. per acre. 
By the spring of 1914 the area of the plantations had been increased to 550 acres. In 1913 a further development was under discussion with the Board of Agriculture, who submitted a scheme for the planting of 761 acres additional over a period extending to the season 1929-1930, or a little over 50 acres annually. The Corporation, while adopting this scheme as a plan to be generally followed, ultimately decided to proceed independently of any loan from or partnership with the Board of Agriculture or Development Commissioners. Since the outbreak of the war this plan has been interfered with owing to lack of labour; and the additional area planted has been about 40 acres only, making the total area under plantation in May 1917 about 590 acres. Mr. E. A. Lees, Secretary to the City of Birmingham Water Department, to whom I am indebted for this information, states that the whole of the lands available for plantation in the Elan Valley are comprised in the scheme of the Board of Agriculture and amount to about 1300 acres. This seems to be a small proportion indeed of the 45,562 acres included in the catchment area; but the explanation is given in the following statement made by Mr. Lees at the Afforestation Conference of 1907 (Parl. Paper, No. 98, p. 41): "There is difficulty in obtaining land for planting. Although we control the whole of our gathering grounds, there are other rights in it; there are, for instance, the rights of the commoners. We can control as regards the surface. Consequently the areas which hitherto we have been able to utilise for planting have been confined to our own freeholds and commons which were already within the limits of our works. If planting is to be carried out to any considerable extent, it will certainly be necessary to give facilities for the recovery of common lands."

The Reconstruction Forestry Report, 1918, p. 94, states that a survey made by the Board of Agriculture disclosed 6800 acres suitable for afforestation on the Elan catchment area.

A full account of the Elan watershed, with plan and 
map, is given by B. L. and W. L. Mansergh in Proc. Inst. Civil Engineers, vol. 190, pp. 3-88 (1912). See also Ward and Baddeley, Guide to South Wales, p. 106 (1903). The average annual rainfall over the whole area is 69 inches.

\section{NOTES}

1. In Journ. Sanitary Institute, xxii. (1901) p. 471.

2. In a valuable paper, "Afforestation of Water Catchment Areas," read before the British Association at Southport in 1903. See Trans. Roy. Scot. Arbor. Soc. xvii. p. 223 (1904).

3. In Proc. Inst. Civil Engineers, vol. 167 (1907), p. 240.

4. In Proc. Inst. Civil Engineers, vol. 181 (1910), p. 148.

5. Water from many of the moorland gathering grounds of Yorkshire and Lancashire, and from lakes in some cases (Loch Katrine, for instance), is not filtered in any way.

6. "The Afforestation of Waterworks Catchment Areas" in Trans. Roy. Eng. Arbor. Soc. vi. 276.284 (1906).

7. See Memorandum to Dundee Water Commissioners, 22nd December 1910, reprinted in Trans. Roy. Scot. Arbor. Soc. xxiv. 191 (1911).

8. In Proc. Inst. Civil Engineers, vol. 167, p. 154 (1907).

9. See Report of Royal Commission on Housing, Scotland, Blue Book, Cd. 8731 of 1917, pp. $253,254,260$.

10. This paragraph is taken from Return as to Water Undertakings in England and $W$ ales, Parl. Paper, 1915, No. 395, p. xxxvi.

11. See Journal of Board of Agriculture, xvi. p. 265 (July 1909); also Trans. Roy. Scot. Arbor. Soc. xxiii, p. 22 (1910).

12. An interesting account of the Vyrnwy and Rivington Afforestation Schemes was given by Mr. Joseph Parry at the Board of Agriculture Afforestation Conference on 25th June 1907 (Parl. Paper, No. 98, pp. 26-30). Mr. Harmood Banner, of the Association of Municipal Corporations, considered that municipalities were bound to afforest around their sewage-farms, "to hide that ugly blot which so very often comes near our towns fand disfigures the scenery."

13. An account, with map, of the Vyrnwy Waterworks is given by G. F. Deacon in Proc. Inst. Civil Engineers, vol. 126, pp. 26-69 (1896).

14. An account, with map, of the Thirlmere Waterworks is given by G. H. Hill in Proc. Inst. Civil Enginecrs, vol. 126, pp. 4-25 (1896).

15. See W. R. Fisher, Working Plan Report of Woodlands round Lake Thirlmere (1908); and Sir Bosden Leech, in Board of Agriculture Afforestation Conference Report, 1907, p. 38.

16. In Fig. 15 the three different operations of the mattock in planting stony ground are shown from left to right: (1) The turf is pared off with the flat end of the mattock, the pointed end being used for loosening the soil ; (2) the plant is inserted; and (3) the plant is made firm in the soil. In ordinary soils the plants are notched with spades into the pits prepared by the mattock.

17. See Timber Trades Journal, 19th October 1918, p. 503.

18. See Minutes of Evidence, vol. ii. part ii. p. 224, Royal Commission on Coast Erosion (1909). 


\section{CHAPTER VIII}

\section{CONDITIONS AFFECTING THE PLANTING OF WATER}

CATCHMENT AREAS

IN considering the advisability of afforesting a water catchment area, the principal points to be ascertained are the acreage and situation of the land that will prove suitable for planting and the species that ought to be employed. Before drawing up any scheme a preliminary survey of the ground is necessary, careful attention being paid to the different factors that influence the growth of trees. In other words, the altitude, shelter from wind or exposure, the nature and depth of the soil, and the existing vegetation must be ascertained for each of the different sections into which the area can be conveniently divided. It is very seldom that the whole of a watershed can be covered with trees. Plantations will not succeed at a high elevation or in exposed situations, or where the ground is covered with solid rock or with deep wet peat. It is generally admitted that the larger the block to be planted, the more economical will be the initial cost of fencing and planting, and the expense of care and management in after years. This argument need not be pushed to extremes in the case of municipally owned land, where commercial profit is not the sole consideration. On catchment areas where extensive schemes of afforestation seem impracticable, it will be advantageous to plant belts of trees or narrow plantations around the reservoirs and above the streams leading into them, and by this means diminish the risk of contamination 
from adjacent arable land or pasture. Small plantations of this kind will scarcely produce remunerative timber, but their establishment can be justified as a hygienic measure.

As most of the gathering grounds of water supplies lie in hilly or mountainous districts, and often include a good deal of moorland, it will be of interest to discuss at some length the factors that influence the growth of trees in such situations in the British Isles.

The existing vegetation on an area gives the most important clue as regards the possibility of success or failure of artificial plantations. In most parts of England, Ireland, and Scotland three well-defined zones of vegetation can be readily distinguished, namely, the agrarian zone, the zone of hill pasture, and the moorland zone. Lowest of all is the agrarian zone, which comprises the farm land, including cultivated grazing land, as well as most parks and much of our woodlands. In the agrarian zone there are, however, great tracts that have never been brought under cultivation, as the heaths of southern and eastern England and the lowlying peat-bogs in Ireland. Nevertheless, most of this zone was originally covered with forest, and any part of a catchment area coming within it can, as a rule, be planted, unless conditions of the soil, like the occurrence of deep peat, marsh, etc., prevent the growth of trees. In other words, up to a certain altitude, namely, to the line above which oats cease to be cultivated, plantations are usually successful and remunerative.

The zone of hill pasture occurs above the farm land, and is mainly devoted to sheep and cattle. It is very variable in its composition, and includes a considerable amount of woodland and scrub. It extends up the slopes of the hills and mountains, and ends practically where the soil becomes peaty and the moorland begins. It is probable that the whole of this zone was once covered with natural woods, and hence its great importance in schemes of afforestation. It constitutes a good part of the so-called waste land, which, it is believed, would pay better if covered with 


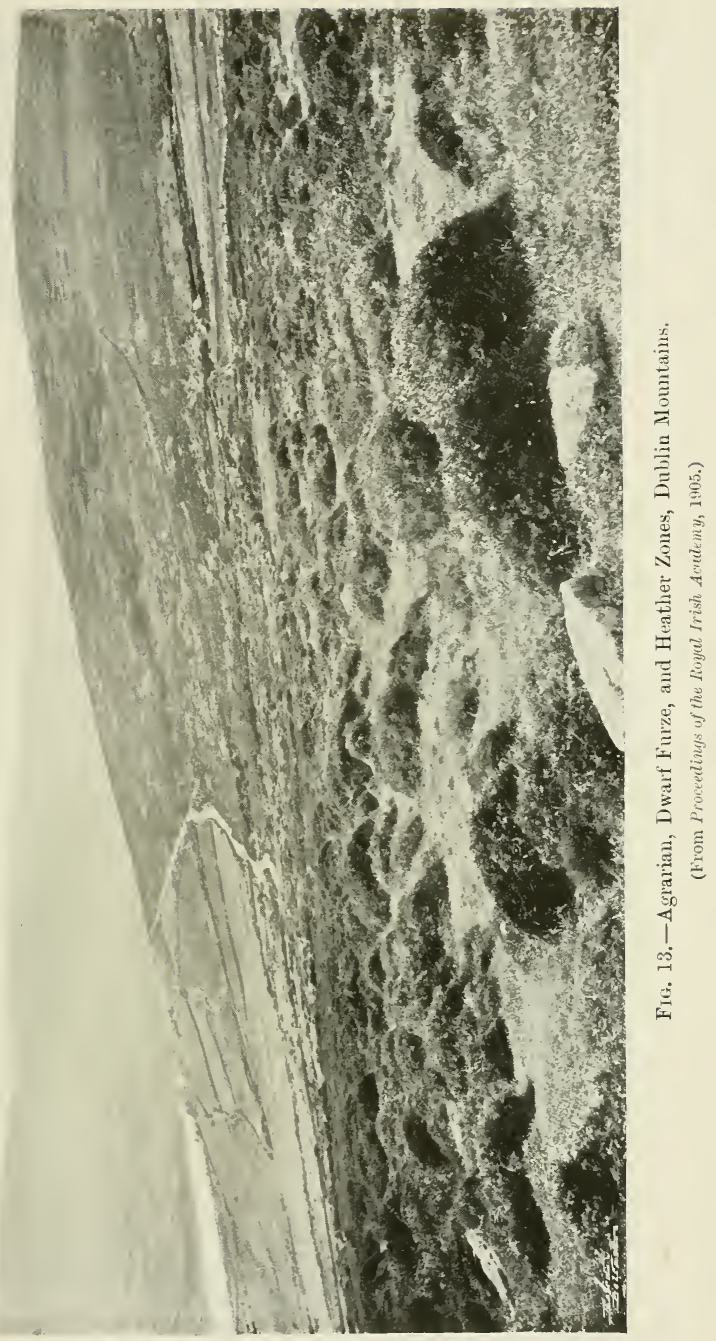



trees than if left in its present state as poor grazing land.

The hill pasture is often common land, serving as grazing for sheep and occasionally cattle in the summer months, and in such cases it is troublesome to purchase the grazing rights from the numerous owners who occupy the farms below. The Birmingham Corporation had great difficulty in getting rid of these rights on their catchment area in Wales. Prof. Somerville estimates that the average amount of mutton produced on poor hill pasture in Wales and in Scotland is about $10 \mathrm{lbs}$. per acre annually. Afforestation of the hill pasture would apparently displace the sheep and to some extent diminish the meat supply of the nation. These calculations do not, however, take into account the amelioration in climate brought about in high-lying districts by afforestation. The shelter provided by plantations in the zone of hill pasture has a marked effect in improving the value of the grazing and arable lands in the farms immediately below. In the mountains of Denbighshire and Wicklow wherever there are farms protected by plantations, the farmers are enabled to keep sheep out in the winter, and all stock thrive better. The upper limit of the arable land is pushed higher when there are sheltering plantations, and the gain to the district is considerable.

The last point is of considerable importance. Most writers advocate the afforestation of mountain waste land in large continuous blocks, and do not consider the effect upon the adjoining land. It is possible that a joint scheme of afforestation and reclamation would be more profitable than a scheme of afforestation only. Mountain slopes might be planted in widely separated blocks, joined on the upper side by narrow belts, the intervening blank areas being utilised for grazing and farming. The pasture of these areas might often be much improved by draining and by manuring with basic slag, which induce the production of grass in greater quantity and of better quality. Where there are great numbers of small farmers, as in Wales and 
Ireland, extensive hill plantations and shelter belts might be made on the co-operative system if State aid in the shape of loans for planting were available.

The recognition of the hill-pasture zone is easy if it is understood to include all the ground above the enclosed farm land and below the heather moorland. Its altitude is variable, ranging, for example, in the Dublin Mountains between 900 and 1250 feet and in the Northern Pennines between 1000 and 1250 feet. It is also very variable in composition, including woodland, scrub, grassland, brakes of bracken fern, and thickets of small whin (Ulex gallii) on siliceous soils. In the Pennines the natural wood is mainly oak or birch, the former small and scrubby above 1000 feet, the latter ascending to 1250 feet. The grassland consists mainly of mat-grass (Nardus stricta) and silver hair grass (Deschampsia flexuosa) on the drier soils, with sheep's fescue (Festuca ovina) at the lower levels, while the wetter ground is dominated by purple moor-grass (Molinia caerulea). Bracken occurs over large areas in places, and its present upper altitude line corresponds very closely with the limit reached by the pre-existing forest. In fact, wherever bracken and small whin are present they are a sure sign that plantations may be tried with confidence. Dr. W. G. Smith says: "Bracken is an indication of a soil at least six or nine inches deep, moist yet well drained, and not peat, because only in these conditions can the underground stems of this fern survive; the conditions are therefore suitable for afforestation." The small whin occurs only in patches in the Pennines, but is very abundant on the Malvern Hills and the Dublin Mountains. On limestone soils the zone of hill pasture has a different composition, the characteristic woods being ash, birch, and wych elm, while the grassland is a short grassy turf, largely composed of roots of sheep's fescue. The characteristic grasses of non-limestone soil, Nardus, Deschampsia, and Molinia, are totally absent. Bracken, whin, and rushes, so common on siliceous soils, are of very rare occurrence, and perhaps are confined to leached soils or soils mixed with non-calcareous material. 
The moorland zone, occurring on the hills and mountains above the limits of the hill pasture, owes the peculiar character of its vegetation to the presence of peat, which varies in depth from a few inches to many feet, and overlies shale, sandstone, granite, and other rocks, but is rare on limestone. The peat also varies much in the quantity of water which it contains, and to this is due the various types of vegetation that are met with in the moorland zone. Botanists distinguish in this zone, as main types or associations, heather moor, cotton-grass moor, Scirpus or spike-rush moor, bilberry moor, and Sphagnum moor.

Heather grows on peat where the drainage is good, and is most vigorous when the water content of the peat is less than 50 per cent. It thus occupies the slopes of the hills and mountains immediately above the hill pasture, and ceases to thrive on the higher parts, where the ground is flatter and the drainage is impeded. There are thus, as a rule, extensive heather moors on the slopes with shallow and dry peat, succeeded above by cotton-grass, Scirpus, and Sphagnum moors, where the peat is deep and sodden with moisture.

The lower limit of the heather moor is determined by the cessation of the peat and is very variable. It occasionally descends in the Southern Pennines to 750 feet, but as a rule in this range seldom goes lower than 1000 feet elevation. Its upper limit is mainly a question of drainage and scarcely depends on altitude, as heather grows to a high elevation if the peat is dry. In the Southern Pennines the heather moor ascends to about 1500 feet, but it often gets up to 2000 feet in the Northern Pennines. The heather moors are the typical grouse moors, and are often preserved for shooting, the heather being set fire to every few years to promote young growth.

The heaths in the south of England, which are often immense tracts at a low elevation, are also covered with heather, but are distinct from the heather moors in the nature of the soil. The soil of the moors is always peat, whereas that of the heaths is poor sand or gravel, the upper 
part of which is mixed with dark humus, passing at the surface into a very thin layer of acid dry peat. In most heaths a hard 'pan' forms at some distance below the surface of the soil.

In north-east Yorkshire there are heaths at a high elevation, between 800 and 1250 feet, which are developed on a few inches of humous sand, covered by two or three inches of sandy peat, and passing down into sand. These heaths, inasmuch as the dominant vegetation is heather, are popularly called moors, and are used for preserving grouse; but they differ from the heather moors of the Pennines and of the Dublin Mountains, which rest on pure peat of a considerable depth.

Similarly in the central and eastern Highlands of Scotland, namely, in the basins of the Tay, Dee, and Spey, there are immense heaths, between 500 and 2000 feet elevation, which are colloquially termed moors and are used for grouse shooting. These heaths are somewhat intermediate in character, as the heather grows in a greater depth of surface peat, four to eight inches, than occurs in the English heaths, but, like the latter, they are developed on sandy or gravelly soil, in which acid peaty humus has accumulated. At a depth of one to two feet there is often a layer of moor-pan.

Heaths are much drier than heather moors, and for purposes of afforestation must be considered quite distinct from the latter. Extensive wild and cultivated forests of Scots pine occur on the heaths of the Scottish Highlands; and this species, if unchecked by man, would speedily colonise the heaths of the south of England. Heaths are thus very suitable for plantations of conifers, especially of pine and larch, the only hindrance being exposure to the wind where the land is at a considerable altitude and not protected by surrounding high mountains. Heather moors are not so favourable for afforestation on account of the depth and wetness of the peat, on which trees will rarely grow big enough to yield commercial timber, unless the situation is sheltered and the peat is drained.

Above the zone of heather moor, the peat usually 
becomes deeper and wetter, especially on the badly drained plateaux, and heather ceases to grow or loses its vigour, becoming thin and stunted. On the wet moors other plants take the place of the heather, the most widely spread being cotton-grass (Eriophorum angustifolium and $E$. vaginatum), spike-rush or Scirpus caespitosus, and various species of Sphagnum moss. All these plants grow in deep peat sodden with moisture. The highest wet moors are often the cotton-grass moors, characterised by the growth of one or both species of Eriophorum, on peat rarely less than 5, often 10 to 15 and even 30 feet in depth and saturated with water. Scattered amongst the cotton-grass moors are limited areas of Sphagnum moor, also on very wet peat. Cotton-grass moors are common in the Pennine range on gently sloping plateaux, between 1200 and 2200 feet elevation, and on account of their wetness are locally named mosses. Peat is being formed at a rapid rate in them at the present time. The Scirpus moors are also developed on deep peat, which is still being accumulated, and is saturated with water at most times of the year. The Scirpus is often mixed with a considerable amount of stunted heather. The Scirpus moors are very widely spread in the north of Scotland, the western Highlands, Hebrides, Shetlands, etc., and are common in the Dublin Mountains at lower elevations than the cotton-grass moors. Peat is also being formed at the present day in the Scirpus moors.

In the southern Uplands of Scotland and the western Highlands, Westmorland and Wales, there are the so-called grass moors, which cover extensive areas of badly drained glacial till and boulder clay. The dominant vegetation consists of moor-grass (Molinia caerulea), mat-grass (Nardus stricta), and rush (Juncus squarrosus), growing on a peaty acid soil, which is wet during most of the year. A surface peaty layer, consisting of a sod six to nine inches thick, made up of bases of shoots and rhizomes, rests on an impervious subsoil. The grass moor is not a true moor as the soil is not pure peat. It is much wetter than ordinary hill pasture and has less value for grazing. 
The wet moors are unsuitable for afforestation, as trees cannot grow in sodden peat containing a large amount of water. All the peaty moorlands, in which the common plants are cotton-grass, Sphagnum, Scirpus caespitosus, heather, crowberry (Empetrum nigrum), and purple moorgrass (Molinia caerulca), cannot be planted with trees as long as they remain in their present condition. The soil is much too wet and too sour. Attempts have been made to cover such areas with plantations, but it is doubtful if this has ever been accomplished on commercial lines. For trees to have any chance of success, a great deal of preliminary work is necessary, as the peat must first be thoroughly drained, so that all stagnant water is removed. The upper surface of the peat, consisting of the roots of cotton-grass, Scirpus, heather, etc., matted into a tough fibrous sod, must be broken up and converted by decay into mould, before young trees can secure a footing. The removal of the upper layer of the peat to a depth of one or two feet gives young trees a better soil, but this is an expensive process. Probably the most economical method is the system (Fig. 17) introduced from Belgium into Scotland by Sir J. Stirling Maxwell. Shallow drains are made a few feet apart. The turfs, cut out of the drains, are placed face downwards on the intervening ridges and left to weather for a year. By that time the ground has begun to dry, the turfs have sunk considerably, and the herbage below them has begun to decay. On each inverted turf a young tree is planted, a handful of ordinary soil or sand being put in with each plant. Further particulars of the Belgian system of planting on peat moors will be found in Trans. Roy. Scot. Arbor. Soc. xx. 1-7 (1907), and xxviii. $72-78$ (1914).

Planting in the peat moors will scarcely ever be directly profitable, as the timber produced does not justify the expense. Nevertheless there is much to be said in favour of planting narrow belts of trees in the heather moor immediately above areas that are being afforested in the adjoining hill pasture. In hilly and mountainous 


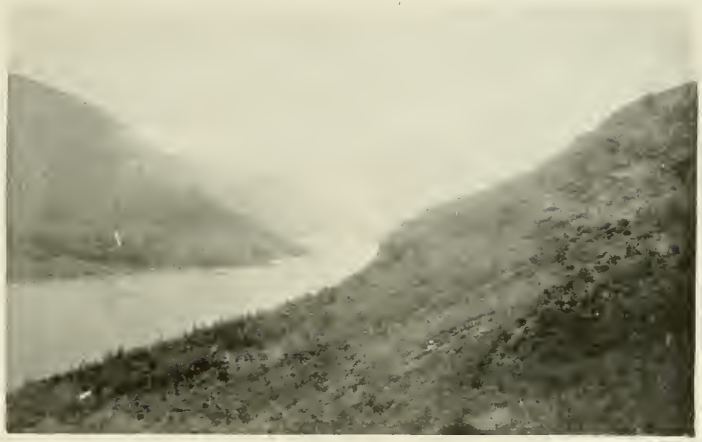

FIs: 14. - Thirlmese Catchment Area, general view. (From E. P. Stebbing. Rritish Forestiy.)

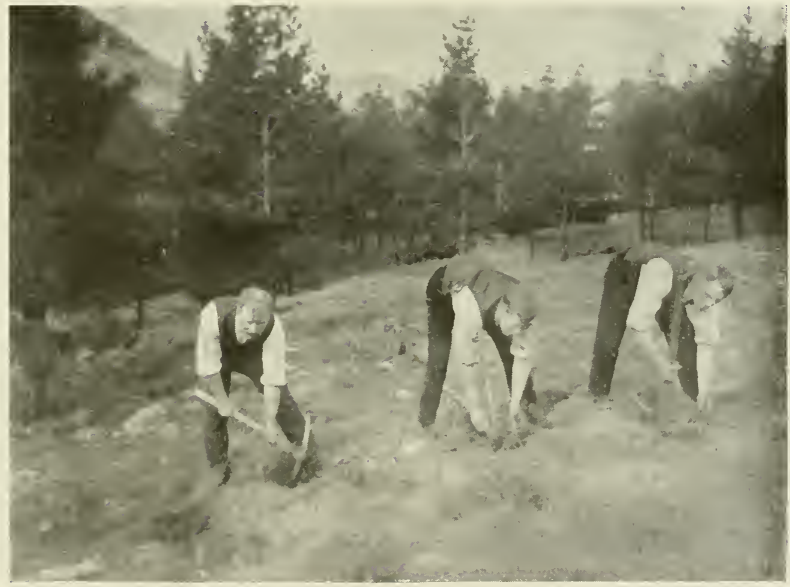

Fir: 15. - Mattuck planting on Thirlnere Catchment Arra.

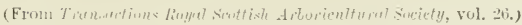




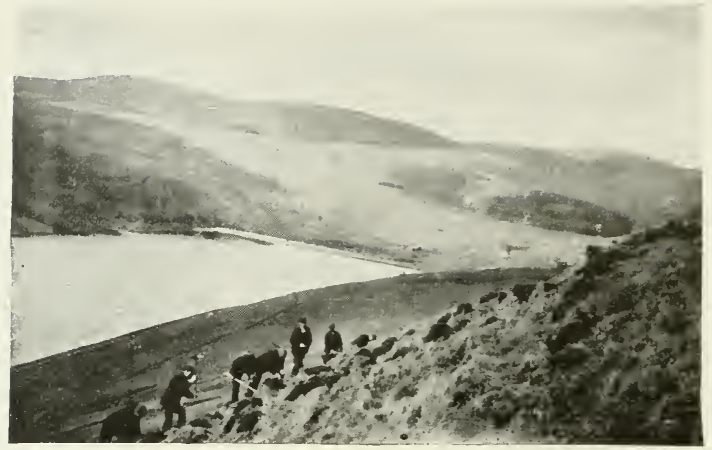

Fis: 16. - Tilla ratchment Area, planting April 1914. (From E. P. Stel,bing, Iritish Forestry.)

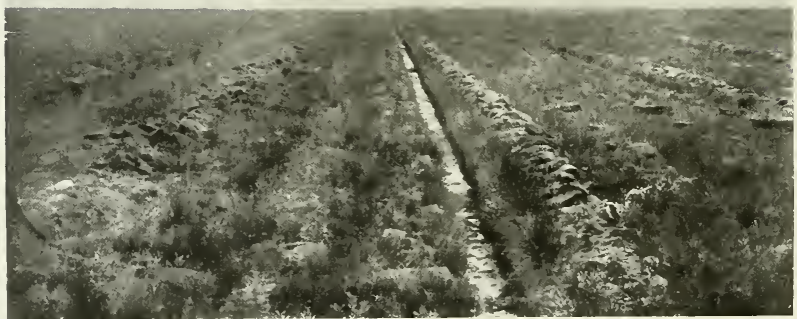

Fig. 17.-Belgian Methor of planting Peat, four rows of inverted turfs letween the drains.

(From Transactims Rogyel scottish A rbovicultural Suciety, vol, 28.) 
districts, the upper zone of any plantation, no matter of what altitude, is stunted, broken, and battered by the wind. It is advisable, then, to carry planting on hill slopes some distance beyond the favourable ground for trees, as in this way an upper shelter belt is formed, which will be very useful in breaking the force of the wind. Practically, then, the only plantations that should be attempted on peat moors are in the nature of shelter belts.

The effect of altitude on trees will now be briefly considered. The lowered temperature and short growing season at high altitudes militate against growth of vegetation; and, as is well known, trees cease to exist above a certain elevation, varying with the climate and latitude. Mere altitude is, however, scarcely so important as other factors, which depress the timber-line, the name given to the limit to which woodland ascends. Trees, on account of their extensive foliage surface, transpire enormous quantities of water; and their growth is checked or stopped altogether when the transpiration becomes excessive. Wind increases transpiration, and the greater the velocity of the wind, the greater the transpiration. At high altitudes the wind is more constant and attains a greater velocity than at low levels; and the main cause of the low timber-line in the British Isles appears to be the force and constancy of the prevailing winds.

This view is confirmed by recent investigations in Switzerland by Dr. Brockmann-Jerosch, who states that the upper tree limit is not determined by any one factor, such as rainfall, snowfall, or the average temperature of the year. It is determined for each locality by the physiography or lie of the land, or in other words by the exposure. This agrees substantially with the fact that in a continental climate, with hot dry summers and cold severe winters, the tree limit in the mountains is higher than in an oceanic mild climate, as in the latter there is more wind and consequent increase of transpiration. The best example in Scotland is the great height of the tree-line in the Cairngorm and Deeside Highlands, as compared with the 
Inverness and Argyllshire Highlands. The climate of the former may be considered continental and that of the latter oceanic; but it is probably the exposure to the wind which makes the difference in the height of the tree-line.

Dr. M. Hardie's interesting remarks on this subject in Scottish Geographical Magazine, May 1906, are worth quoting in extenso at the risk of some repetition: "The upper forest limit is determined entirely by wind. It is higher in the east than in the west, at the eastern than at the western exposure, in the south than in the north. Fairly constant at an altitude of from 1800 to 1900 feet in the middle Highlands, it rapidly goes down to from 1400 to 1500 feet on the scattered and exposed mountains of Sutherland, eventually reaching a much lower level on the western slopes of the extreme north-west, which increases in width from south to north and from east to west. It is followed upwards by a pseudo-alpine belt of a few hundred feet in height. Whether this zone could not be partially reclaimed in course of time by modern scientific forestry is yet an open question." Speaking of the western Highlands, he continues: "In the west we have to deal with an essentially pastoral landscape. The whole of this section is, to a surprising degree, bare of forests, not from any natural cause, but through the agency of man. That this work of destruction has been made easier by the fact that in the sub-alpine zone a species of forest tree, thoroughly adapted to the climate, was lacking, is, however, very likely. For the excess of rainfall and wind is not favourable to Scots pine, the only native timber of importance for this zone, or to the larch, which has much the same ecologic requirements. Norway spruce, silver fir, and the Douglas fir would, under proper management, be best suited to these western hills."

Prof. W. Somerville, in Quarterly Journal of Forestry, vii. 144 (1913), mentions an area of several hundred acres of fine old Scots pine in the Highlands between 1000 and 2000 feet altitude. He gives a photograph of well-grown trees at 1800 feet. Not a single young tree could be 
found. This total absence of pine seedlings is due to the abundance of red deer, which are even more destructive than sheep to young trees. It is probable that deer have contributed to the lowering of the timber-line in Scotland.

In determining the height to which plantations may be carried, the altitude, exposure to wind, and soil must all be taken into consideration. Where there are great masses of high mountains, the timber-line is raised a great deal, and trees may be successfully planted up to high elevations. This is well seen in the Highlands of Central Scotland, where several peaks exceed 4000 feet. In Rothiemurchus Forest, in Strathspey, which lies in a basin enclosed and protected from wind by the Cairngorm Mountains, native Scots pine creeps up the hills to a height of 2000 feet. On the Ardverikie estate in Inverness-shire there are plantations of Scots pine and larch, on the hills beside Loch Earba, doing well between 1500 and 1700 feet. The highest wood in England occurs in the Pennine range. This is a plantation of 300 acres, at Ashgill, lying to the north-east of Cross Fell, the highest peak of the Pennines (2930 feet), by which it is sheltered from the prevailing wind. The elevation of the plantation varies from 1250 feet along the bed of the South Tyne to 2000 feet, the highest point of a shelter belt that was planted in advance of the main crop. The greater part lies between 1500 and 1800 feet, sloping gradually towards the north-west. The soil is glacial clay resting on limestone, the surface being covered with a foot or two of peat. The trees, which were 50 years old in 1906, consist mainly of European spruce, forming a thick even crop, and attaining 36 to 45 feet in height at 1700 feet, and 60 to 75 feet at 1250 feet elevation. The volume per acre was 3500 cubic feet at the higher altitude, and 4500 cubic feet on the side of the River South Tyne. Mingled with the common species there were some American white spruce, which had succeeded well on the exposed margins at high elevations. This remarkable plantation is described fully by Mr. A. C. Forbes in Trans. Roy. Scot. Arbor. Soc. xx. 153 (1907), who 
estimated the average annual yield to be 60 cubic feet per acre, or a gross return of 30 shillings per acre, spruce finding a ready sale here at $6 \mathrm{~d}$. per cubic foot as pit timber.

In the Peak District a plantation of about 1000 acres, lying in the Goyt Valley, south-west of Taxal, extends up to 1700 feet elevation; but all the trees that were planted in exposed situations at high altitudes or on wet moorland peat failed completely. Beech is vigorous and healthy up to 1250 feet, and conifers flourish to about 1500 feet elevation in this plantation. Spruce plantations on Kerry Hill in Wales succeed fairly well up to an elevation of 1500 feet.

On the west coast of Scotland, and in Ireland generally, the timber-line, owing to the strong prevailing wind, is considerably depressed as a rule. In the Wicklow Mountains there are, however, good conifer plantations up to 1200 feet elevation in situations sheltered from the west wind.

It is often asserted that 1000 or 1200 feet represents the upper limit of profitable afforestation; but there is no definite line, as so much depends on the presence or absence of shelter and on the nature of the soil. In most parts of Great Britain the elevation to which plantations may extend varies between 1000 and 1500 feet; but in the west of Scotland and in the greater part of Ireland there are many localities where trees cannot be successfully planted above 700 feet. Even in the south of England proximity to the west coast makes plantations at a high altitude unprofitable. On Exmoor, west of Porlock, 830 acres of the Ashley Combe estate, between 1000 and 1400 feet elevation, were planted in 1850-1860 with larch, spruce, and Scots pine. In 1913 the plantation was reported to have been a failure financially, 500 acres being a dead loss, while " 200 acres . . . will never develop into marketable timber and are not worth more than what has been spent on them in cleaning, thinning, etc., without reckoning anything for the cost of planting and rent of land. Only 100 acres in the most favoured situations have given 
a good return for the original outlay upon them." See letter from the agents of this estate in The Times, 17 th December 1913.

In comparison with continental regions in Europe or America, it is remarkable the low altitude to which any kind of cultivation, whether farming, grazing, or forestry, can be carried in the British Isles. This is always a subject of wonder to foreign visitors. Fortunately, however, the area at high elevations is not a great percentage of the total area. In Great Britain, of the total area (excluding water) of $56,199,980$ acres only $3,537,172$ acres, or $6 \cdot 3$ per cent, is over 1500 feet elevation. The proportion is greatest in Scotland, with a total area of 19,069,674 acres, of which 2,642,529 acres, or $13 \cdot 3$ per cent, is over 1500 feet. In Ireland, of a total area of 32,502 square miles, only 1672 square miles, or a little over 5 per cent, is above 1000 feet altitude.

The division of the country into three distinct zones (Fig. 13) of vegetation, the nature of which has been discussed at length in the preceding pages, leads to certain conclusions of some economic interest. These may be thus summarised :

1. In the upper zone, that of the moors, no cultivation of any kind is possible, or at any rate profitable. The land may be cheerfully resigned to the sportsman and the tourist. It gives in grouse, in deer, and in recreation a considerable return.

2. In the middle zone, that of hill pasture, two industries are possible-grazing and growing timber. Their interests need not clash. The shelter to adjoining pasture afforded by plantations is worth more to the grazier than the possession of the ground which the trees cover. Furthermore, plantations may actually add to the grazing area. In larch and other conifer plantations on poor mountain land, which have reached 20 or 30 years old, there is often an undergrowth of grass, superior in quality to the scanty rough herbage outside. Sheep and cattle may be admitted into these plantations. This extra grazing and the pro- 
tection of the trees are equivalent to an increase in the acreage of the land on which stock can be kept during winter. At Achnacarry weak ewes are habitually wintered in Lochiel's larch woods, with satisfactory results. The useless bracken areas can also be planted up. In short, the shepherd actually increases the numbers of his flock by surrendering part of the hill pasture land to the planter. An actual survey will readily demarcate the land in the hill pasture zone suitable for planting, and the land that is best fitted for grazing. The demarcation should be based entirely on economic lines. Areas on which there is no prospect of growing trees profitably should be left alone.

It is scarcely necessary to point out that the combination of grassland and woodland utilises much better than grazing alone the hill pasture zone, and really diminishes the amount of waste land. Some attention is now being paid in England to the neglected agricultural problem-the improvement of the poor hill pasture. Various remedies are discussed in Board of Agriculture Leaflet, No. 275, but a most important measure, the provision of shelter by trees, is not mentioned. The agriculturist still looks upon the forester as an enemy or as a faddist. Concerning the mutual benefit and relationship between pasture and forestry, see the remarkable study, "The Forest Survey of Glen Mor," published in Trans. Roy. Scot. Arbor. Soc. vol. xxv. (1911).

3. The agrarian or lower zone in great part is claimed by agriculture. The upland farmer profits largely by the establishment of woodland in the neighbouring hills. The timber and fuel which he needs are much diminished in price; and when the time for felling arrives, the sawmills and woodworking industries that may be installed will enhance the value of his produce. As the shelter of the woods increases he extends his cultivation upwards, reclaiming, bit by bit and year by year, the lower and better portions of the hill pasture. 


\section{CHAPTER IX}

TREES FOR WATER CATCHMENT AREAS AND FOR GENERAL PLANTING

OF equal importance with the selection of suitable situations for planting is the proper choice of species. A great many kinds of trees have been tried in the British Isles; and so much information has been amassed concerning them that there is no difficulty in assigning to each species its exact value as a forest tree in this country. Some species are of especial value for shelter. Others are suitable for the formation of a protection zone at high altitudes. A few species, producing timber in a short period of years in great quantity and of good quality, are fitted to constitute the main crop. In any planting scheme regard must be paid to the varying requirements of each species on soil and situation.

Conifers are chosen in the main for new plantations on account of the ease with which they can be planted, and because, as a rule, they yield large returns and can be grown on short rotations. Nevertheless, there is always room for valuable broad-leaved species. The ash, for example, should be planted in small groups on patches of good soil, such as occur in valleys and near streams. The importance of the beech must always be recognised, on account of the improvement of the soil which it effects by its great shade and abundant leaf-fall. It kills the grass, the great enemy to tree growth; and, mixed with maincrop trees, it stimulates their vigour and increases their production of timber. 
Extensive plantatious of conifers are liable to widespreading attacks of fungi and insects, and to great damage from gales and fire. It is advisable, then, to interrupt the continuity of great areas of conifers by planting, at suitable distances, wide bands of broad-leaved trees. Beech is the most suitable species for this purpose; but ash, sycamore, wych elm, alder, etc., may be added in varying proportions according to the nature of the soil. The influence of broad-leaved trees is manifold. Judiciously distributed in belts or in groups they act as wind-breaks; they are visited by birds which prey upon noxious insects; and the humus, due to their decaying leaves, brings health and vigour to the coniferous tracts. Broad-leaved trees may also be planted along the rides, rowan and grey alder being of use at high elevations.

We are not limited in our choice of species to our few native trees. These are late immigrants from the Continent after the glacial epoch, and are by no means the trees that are most suitable to the climatic conditions of the present day, or that are most fit for producing, as quickly as possible, valuable timber.

The Scots pine, our solitary native conifer of forest importance, was widely spread over the British Isles in the dry, warm, continental climate that prevailed at the beginning of the neolithic period; but it has, with the advent of our present humid, cool climate, gradually disappeared from all parts of the country, except in the mountain massif of the Scottish Highlands. It is most suitable for districts characterised by a low annual rainfall and much sun in late summer and autumn, as in Speyside, Deeside, and Tayside in the north, and in the sandy heaths of the south and east of England. In such districts it regenerates itself freely, and attains a great height, producing a satisfactory volume of timber of good quality.

Fortunately we are not restricted to native trees. During the eighteenth century, spruce, silver fir, and larch from the Continent began to be largely used in our plantations. The movement towards extensive use of exotic trees was 
accelerated by the discovery, in the early part of the nineteenth century, of the trees of the Pacific Coast region of North. America, where, in a climate absolutely similar to our own, the highest and most valuable type of coniferous forest on the planet has been evolved. The Douglas fir, Sitka spruce, Abies nobilis and grandis, Thuya gigantea, Pinus insignis, and Cupressus macrocarpa are perhaps the most important trees from this region. From Asia we have introduced the Japanese larch.

There are numerous other trees, which are occasionally used in our plantations, but scarcely any promise to be of real value. In fact, the pursuit of new species is over as regards commercial forestry. We have all the wild species that we need. It is different with regard to trees of hybrid origin. Remarkable fastness of growth, far surpassing that of wild species of the same genus, is shown by certain hybrids of the first generation, or so-called 'first crosses.' Amongst these may be mentioned black Italian poplar, cricket-bat willow, and London plane, all hybrid trees which originated as chance seedlings. Fast-growing hybrids of trees like ash, walnut, oak, etc., if they could be produced by artificial cross-pollination, would be invaluable; and efforts to make such hybrids have been attempted. One of the most interesting of these artificially made trees is a new hybrid poplar, Populus generosa, produced at Kew in 1912 (see Gardeners' Chronicle, lvi. p. 257 (1914)). As to the quality of the wood of these hybrid trees, I may quote from my article on "The Artificial Production of Vigorous Trees," in Journ. Dept. of Agriculture, Ireland, xv. p. 42 (1915):

"It is a popular belief that fast-grown timber is necessarily soft and comparatively worthless. This is a fact in most conifers; but in one class of broad-leaf trees, the wood of which is characterised by large pores in the inner part of the annual ring, the contrary is true, as the faster the timber of these trees is grown the stronger and denser it becomes. This class includes oak, ash, chestnut, hickory, and walnut, the species, in fact, that par excellence produce the most 
valuable timber. In countries like our own the only hope of salvation for forestry is in growing timber rapidly; and we have been helped in that by the introduction of fastgrowing conifers like the larch, the Corsican pine, and the Douglas fir. But it is essential to grow the more valuable classes of non-coniferous timber. The difficulty of growing ordinary species of oak, ash, and walnut is the long period required for their maturity, which renders hopeless, except on the best soils, all chance of an adequate financial return. Without vigorous first-crosses, the most valuable classes of timbers can only be grown in limited quantity."

As we are largely dependent on exotic trees for the success of our plantations, the proper selection of seed is a matter of primary importance. The seed from which young trees are raised should be gathered from the best trees in the best localities. Species, if widely distributed, are not uniform over the whole territory which they inhabit, but consist of few or many distinct races, each confined to its own district. These races vary much in their qualities. It is well known how superior in vigour the Douglas fir, growing close to the Pacific coast, is to the same species growing in the mountains far inland. The larch at high altitudes in the Tyrol is inferior to the larch growing in the lower Swiss valleys. Seed from straight well-grown trees should always be selected, and that from suppressed or crooked-stemmed trees be avoided. Commercial seed is often collected from inferior trees; and the establishment of seed-collecting stations by the Forest Services of Canada and of the United States, in British Columbia, Washington, and Oregon, would be a great boon to sylviculture in this country.

The principal forest trees will now be briefly considered, with special reference to their adaptability to different conditions of soil and situation. The conifers being the most important class for planting in water catchment areas will be first dealt with. 


\section{Conifers}

Scots Pine.-As mentioned above, this is now the only native conifer used in planting. Wild forests of Scots pine exist in Inverness-shire and Perthshire, occupying the heaths, which are tracts of sandy or gravelly soil covered with a thin layer of peat and carrying a thick vegetation of heather. These forests and also plantations of Scots pine occasionally ascend up to 1800 feet elevation, but only in very sheltered localities. Originally planted in the south of England, Scots pine spreads itself naturally and freely over the heaths of the Bagshot Sands and Lower Greensand, and also sows itself on the heaths of East Anglia and North-east Yorkshire. Scots pine develops a deep tap-root, and in consequence should never be planted on shallow soil, on which its growth remains always stunted. At high elevations it is liable to snow-break. It is most suitable for pure sands, loamy sands and gravels of cousiderable depth, and should not be grown on rich soils, as it then produces wide-ringed soft timber of little value. It thrives on lowland peat, if this is drained; but on wild undrained peat soon ceases to grow, or remains a stunted, useless tree. As a main-crop tree it should be planted close and grown pure, and be thinned lightly only, as in this way the stems are readily cleaned, and the ground kept protected. Grown in mixture with other trees it is liable to be suppressed by faster-growing species, and such suppressed stems are of no value as thinnings; or if it holds its own, it retains its branches and produces coarse and knotty timber. Grown on sandy or gravelly soil at moderate elevations it produces timber of excellent quality, the average yield in good situations being 70 cubic feet per annum. The following measurements were taken by Messrs. E. R. Burdon and A. P. Long: A plot of Scots pine, on good deep sandy loam at Woburn, 95 years old, with 176 trees to the acre averaging 88 feet high, contained 6391 cubic feet of timber (quarter girth measurement under bark), equivalent to an average annual increment of 67 culvic feet per 
acre. Another plot on poor but deep sandy soil, with some iron pan, on the Gaywood Estate, King's Lynn, 91 years old, 216 trees per acre, 65 feet high, contained 4733 cubic feet (quarter girth measurement under bark), equal to an average annual increment of 52 cubic feet per acre.

Corsican Pine.-This species is a much more vigorous tree than Scots pine in most parts of the British Isles. On the sandy heaths of Surrey, Sussex, Hampshire, and Dorset it produces a considerably larger volume of timber, probably as much as 90 cubic feet per acre per annum, for the first forty years on the best sites. It grows freely in dry situations and on soil containing lime, and even succeeds on clay. It bears drought well, thriving on a grassy hill with a south exposure in Somerset, where beech and larch had died. This is due to the thick layer of humus produced by the leaf-fall of this pine, which keeps the soil cool and moist. Having a deep root-system it is very storm-firm, and resisted better than any other conifer the gale of December 1913, when over a million trees were blown down in Perthshire and Forfarshire. It bears the constant prevailing wind well, and on this account is valuable for planting in shelter belts near the sea and in hilly districts. Corsican pine succeeded better on sand-dunes at Holkham, Norfolk, than any other species, producing natural seedlings in great abundance, many of which are now as tall as the parent trees, attaining 30 to 35 feet in height in twenty years. The tree helps materially in defence against seaerosion. See Quarterly Journal of Forestry, ii. 107 (1908). Corsican pine also proved much more successful than Scots pine on the sand-dunes at Culbin, Morayshire, "owing to its adaptability for growing on sand and to its power of resisting wind." See Trans. Roy. Scot. Arbor. Soc. xxix. 25 (1915).

Plantations of Corsican pine on exposed sites in Wigtownshire and in Wales produce a considerable volume of timber, the height growth being about 50 feet at the end of forty years. On the Healey Estate, Northumberland, 
a pure plantation, 50 years old in 1911, had 325 trees, 50 to 60 feet in height, with a volume of 3790 cubic feet per acre, or an average annual increment of 76 cubic feet per acre (Quarterly Journal of Forestry, v. 350 (1911)). At high elevations this tree suffers little from snow, but is not so useful as the spruce. It is not usually injured by rabbits, and is remarkably free from insect and fungus attacks, the only recorded case of disease being an attack of Peziza, reported in Quarterly Journal of Forestry, vii. 287. It produces heartwood at a late period; but the timber of young trees, though all sapwood, is heavy, tough, and resinous, and can be used on estates for the same purposes as larch. Its wood is very durable, a vinery door made of it at Bayfordbury showing no signs of decay after exposure to the weather for twenty-two years. Its cylindrical and straight stems make it very suitable for pit-wood, and it was freely bought for this purpose near Swansea in 1905 .

A remarkable instance of the capacity of this pine for producing a large amount of timber on poor dry soil in Dorset is given in Trans. Roy. Scot. Arbor. Soc. xxiv. 46 (1911). Here planted very close (only $1 \frac{1}{2}$ feet apart), it kept the soil moist with a dense layer of humus, and far surpassed Scots pine in health and vigour. It succeeds remarkably well in the sandy tracts of Surrey. See Gardeners' Chronicle, xliii. 406 (1908). The only objection to the extended use of this tree is the difficulty of moving it out of the nursery. To obviate this, the seedlings should be transplanted at one year old, and be moved every year till ready for planting out.

Austrian Pine.-This is an inferior tree in all respects to the Corsican pine, and is of little value in plantations, the timber which it produces being coarse, rough, and knotty. It is used for shelter belts near the sea-coast and on windy exposed hillsides of chalk or limestone.

Maritime Pine.-This species attains on sandy soil near Norwich, where it is mixed in old plantations with Scots pine, about the same volume per acre per annum as the 
latter tree; but its timber is inferior. It is entirely at home on warm sandy tracts near Bournemouth, where it reproduces itself freely, and attains a large size. Usually, however, it is inferior in growth to the Scots and Corsican pines. At Holkham, on the coast of Norfolk, it does not grow nearly so well on the sand-hills as the Corsican and Austrian pines. There is, however, a flourishing plantation (Fig. 20), 47 years old and nearly 200 acres in extent, on the sheltered side of a sand-hill on the sea-coast at Mullaghmore in Sligo. This plantation has an average annual increment of about 60 cubic feet of timber per acre. At Abbeyleix this species has been cheaply established on a drained lowland peat-bog (Figs. 18 and 19) by sowing the seeds in situ. (see p. 19). It bears wind well in the milder parts of the kingdom, as on the west coast of Ireland and on the south coast of England; but inland or at a considerable elevation the tree is usually a failure, the stems being curved and shortened by the wind. The use of the tree is distinctly limited to the afforestation of sanddunes and of certain types of lowland bogs, where most of the peat has been removed for fuel.

Pinus Montana.-This species, of which there are three main varieties, occurs naturally at high elevations in the Alps, Pyrenees, and other mountains of Central Europe. The dwarf form (var. pumilio) is a creeping shrub of no sylvicultural interest. The intermediate form (var. rostrata) is a small tree, not exceeding 30 feet in height, with several stems arising close to the ground, due to the rapid development of the side branches which turn upwards and grow at an equal pace with the leader. This form has been largely planted on the heaths and dunes of Jutland, where it has been found to improve remarkably the acid heath soil, and render it fit for the growth of other species. It is usually planted in the dunes pure at first; and afterwards common spruce is introduced, which without it could not be grown on this poor soil covered with heather. The upright form (var. uncinata) is an erect tree with a single undivided 


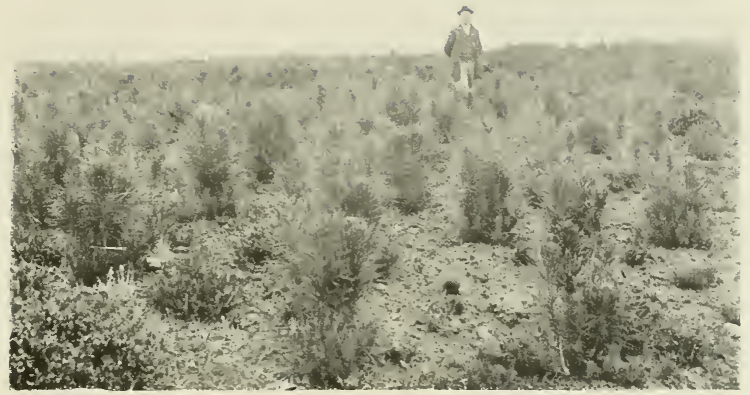

Fir: 18. - Maritime Pine, three rears old, sown on hog at Ahherleix.

(From forentit Life, 2and Ipril 1916.)

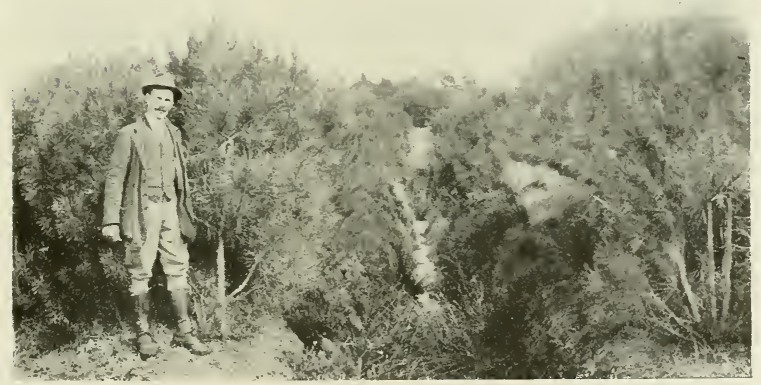

Fig, 19. - Maritime Pine, five years old, sown on bog at Ableyleix.

(From conntiy Life, 22nt April ig16.) 


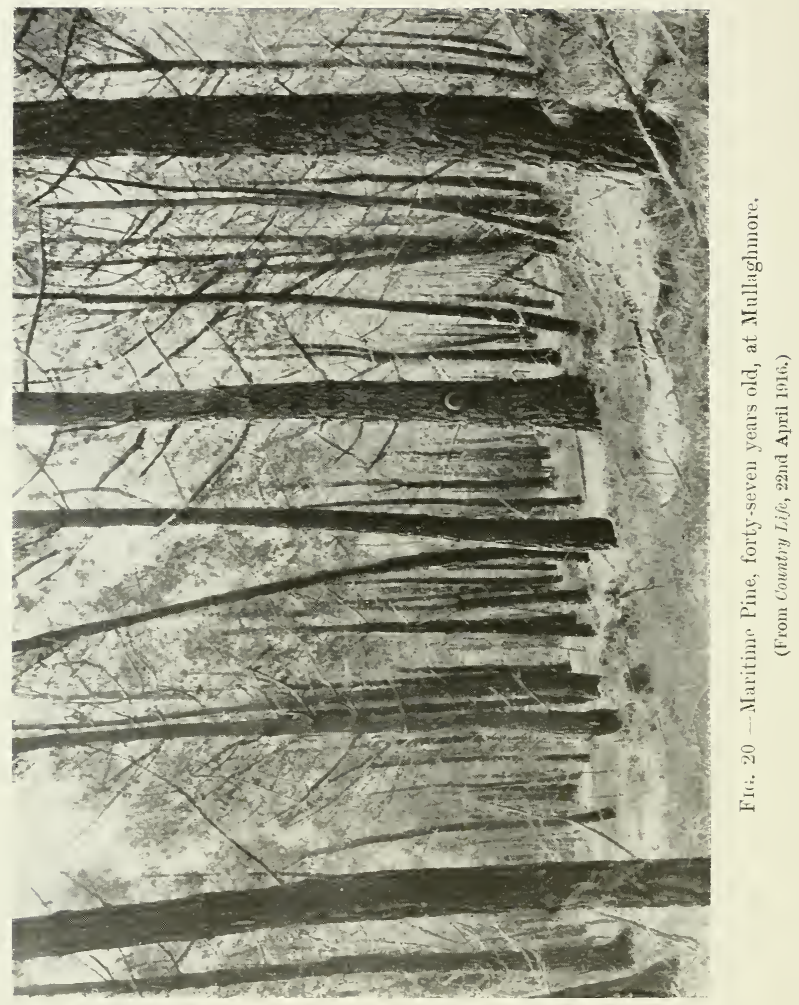




\section{TREES FOR WATER CATCHMENT AREAS 127}

stem, attaining 30 to 70 feet in height, but slow in growth. It is extremely hardy, suffering little from snow, and occurs at high elevations on the poorest soil. Both these forms of Pinus montana grow better in wild, wet, undrained bog than any other species; but in such circumstances their growth is very slow. At Kuockboy, Connemara, 490 acres of peat, at no great elevation, but fully exposed to the west wind, were planted in 1891-1894 with over two million trees, comprising 16 broad-leaved species and ten conifers. Practically none of these survive, except two species-Pinus montana, which has thriven over the whole area, but had attained only 6 feet in height in 1915, and maritime pine, of which there were a few groups about 20 feet high.

Neither form can ever be expected to attain a useful size or be grown commercially in this country. It is possible, however, that Pinus montana may be of considerable value in the heather zone on exposed sites, in mixture with Sitka spruce, Corsican pine, or silver fir. It would greatly improve the peaty soil by its decaying leaves, producing good humus, which would favour the growth of the other species. Its dense foliage, persisting on the branches five to ten years, also protects the soil. It has been tried of late years on high moorland at Corrour in Inverness-shire; and reference may be made to articles by Sir John Stirling Maxwell in Trans. Roy. Scot. Arbor. Soc. xx. 6 (1907), xxi. 1-15 (1908), xxiii. 157 (1910), and xxviii. 77 (1914). See also Quarterly Journal of Forestry, x. 126 (1916). Pinus montana may also be used in mixture with other trees in shelter belts on wet peaty soils.

Pinus Insignis, a native of Monterey in California, makes remarkably fast growth in the milder parts of England, Wales, Ireland, and south-west Scotland. This vigour, often an increase of three feet in height annually, is kept up on the poorest soils, provided the situation is a mild one near the sea-coast. In inland places the young shoots are often injured by frost; and in exposed cold situations trees may be killed outright during exceptionally 
severe seasons. In a plantation of this species formed at Muckross, near Killarney, in 1876, a considerable number of trees were killed in the very cold winter of 1908-1909. In the few plantations that have been made in these islands, the trees are extremely coarse and the quality of the timber very inferior; but the quantity produced is probably as much as 200 cubic feet per acre annually. Planted pure in close order, Pinus insignis would probably produce pit timber that would be highly remunerative in suitable localities. The main value of this species lies, however, in its use for shelter near the sea, where it might give protection to valuable plantations of other trees. Its rapid growth and dense habit adapt it well for this purpose. In Cornwall it stands erect and uninjured in places where Cupressus macrocarpa is badly cut by the wind; and it much exceeds in height the maritime pine on the sea-coast. It is very successful as a wind-break in the most exposed localities in the Scilly Isles. The seedlings should be transplanted annually for the first two seasons, and be planted out in the third year. October is preferred for these operations in the Scilly Isles. Pinus insignis will succeed in poor, dry, and stony soils; but is a failure in wet soils and in soils containing more than a very small percentage of lime. For a shelter belt, a double or triple row, planted quincunx fashion, will usually be sufficient.

Silver Fir.-The common silver fir, Abies pectinata, is a native of Central Europe, and is the most important species of the genus for planting in this country. Abies grandis and Abies nobilis, natives of Western North America, are also worthy of notice, and will be spoken of later.

The common silver fir produces an enormous quantity of timber, but is not ripe for felling at so early an age as larch, Scots pine, Sitka spruce, and Douglas fir. It is nevertheless an excellent main-crop tree, which has been much neglected in this comntry. On the Continent it inhabits the lower zone of the mountains where the rainfall is high, 60 to 80 inches annually, and the soil is fairly deep. 
In the west of Scotland, Wales, south-west England, and Ireland it is at home from sea-level up to 1000 or 1200 feet elevation; and is adapted for the zone of hill pasture wherever the soil is moderately deep. It is not suited for the heather moor or heaths, where pine and larch are the successful species. Silver fir is a good wind-resister, and attains a greater height in the teeth of the wind, whether inland or close to the sea, than any other species. This great height-growth enables it to produce a large volume of timber in moderately exposed situations. Used as a shelter belt in wind-swept districts, it will protect other species planted in masses to leeward and greatly augment their production of timber. Shelter belts of silver fir mixed with beech would also greatly improve pasture lands in the west of Ireland, Wales, etc.

In the young state silver fir is liable to spring frost, and on that account may occasionally require the protection of nurses in its early stage; and for this purpose hornbeam or birch may be used, planted either with the silver fir or one or two years previously. Silver fir may be planted pure or mixed with beech or spruce; and for many years should be kept dense on the ground in order to produce well-shaped clean stems.

In Ireland silver fir scattered in mixed woods regenerates itself very freely, as the seedlings spring up in great numbers amid the ordinary woodland herbs, and grow well in the partial shade. Shelter belts and plantations of silver fir mixed with beech, sycamore, and ash could always be naturally regenerated, and would often be very remunerative.

The timber ordinarily produced by silver fir in this country has been rough, branched, and knotty, as it was usually thinned too early or mixed with unsuitable species like Scots pine. Grown in complete canopy, it produces an extraordinary volume of timber, only surpassed in this respect by Douglas fir and Sitka spruce. On favourable sites 100 to 120 cubic feet per acre per annum may be expected. Grown close the timber is narrow-ringed and of excellent quality. 
On Deeside, according to Mr. Crozier, "the common silver fir, formerly one of the most reliable trees, is now hopelessly unreliable as a timber crop owing to its susceptibility to Chermes. Old trees are immune; but the difficulty of raising young stock is likely to lead to its extinction altogether as an economic species." This difficulty exists elsewhere, but can be overcome. Young plants should be raised under shade in nurseries situated in woodlands, and when planted out ought to be always mixed with beech. In Wicklow natural seedlings of silver fir keep free from Chermes, while planted seedlings close by are liable to attack. The attack occurs not long after they are planted out, the period when their growth and vigour are checked by the act of transplantation.

Abies grandis.-This is the fastest in growth of all the silver firs; and isolated trees in different parts of the British Isles often equal and sometimes excel the Douglas fir in vigour. Associated with this vigour is good health, as, unlike the common silver fir, it is not attacked by Chermes, and is not liable to injury from frost in the young stage. An acre of this tree in Sussex, which was planted in 1900 , had attained in 1917 an average height of 35 feet and a girth of 21 inches. The seedlings are easily reared, grow much faster than those of the common silver fir, and may be put out when three years old after being transplanted once. Abies grandis may be tried as a maincrop tree in localities where the common silver fir is difficult to establish on account of Chermes and late frosts. It is not known whether it will resist wind as well as the common silver fir, and it does not bear so much shade as the latter.

The timber in western North America is little known commercially; but is probably better than any of the other American silver firs except Abies nobilis. It is white and soft, yet firm enough to be useful.

Abies nobilis. - This species is a mountain tree in western North America, and differs from Abies grandis in its 
climatic requirements. It has not proved very successful as an isolated, ornamental tree in the milder parts of the British Isles, being prone to Chermes attacks, and often weakened by excessive production of cones. It is much more at home in the colder parts of Scotland, where it promises to be a valuable tree, as it is quite unhurt by the severest frost and is never injured by the heaviest snowfall. At Durris, Ardverikie, and Corrour, it is extremely hardy (Fig. 28) and resists wind better than any other conifer. Planted out on exposed sites, it has done well even on peaty soil. At Ardverikie it is the most vigorous of all the trees that have been planted there, enjoying immunity from fungus and insect attacks and producing natural seedlings in great abundance. Seedlings raised at Durris and Ardverikie from home-grown seed are very vigorous. It does not bear much shade, and fails where there is lime in the soil. In its own home it produces the most valuable timber of all the American silver firs, the wood being heavy, hard, and firm, and working easily and well. At Durris the wood is white and soft, but closer in the grain than that of Abies grandis.

This species should be planted pure in the protection zone, when this is pushed high up in the heather moor. In this way in the west of Scotland it may be planted up to 1200 or 1300 feet, making a useful belt above the limit of the main-crop trees. It seems to be the most suitable species for use in an attempt to raise the timberline on exposed sites on peat in the Highlands of Scotland and in the west of Ireland. Useful in this way at high altitudes it should never be planted at low elevations. At Craigo, near Montrose, not far from the coast at a low elevation a plantation of six acres of this species, 40 years old, shows only moderate growth, the trees being about 46 feet high by 4 feet in girth.

Douglas Fir.-This is perhaps the most valuable tree that has been introduced. It produces an enormous volume of excellent timber, and comes to maturity in a short term 
of years, being ready for felling at 50 to 60 years old, or even less. It is suitable for all parts of the country in selected sites. It suffers from the wind in exposed situations, and does not thrive in soils containing more than 2 per cent of lime or on wet soils. It grows well enough at high elevations, but only in shelter, succeeding in Wales in favoured spots up to 1250 feet elevation. On wet soils it is very liable to be thrown down by the wind. In the young stage it is liable to injury from frost, and is readily attacked by rabbits. These are its sole drawbacks. It is a splendid main-crop tree for sheltered situations either in the lowlands or high up in valleys in the hill pasture zone, where the soil is moderately deep and not too wet. It will grow fairly well on shallow soil, but then makes superficial roots and is liable to be blown down by the wind. It produces a fair amount of good seed in this country, and in many places, as in the New Forest, regenerates itself freely. At Dunster, Somerset, self-sown seedlings, up to 35 feet high, occur scattered about the estate.

The yields from various plantations, published in the Journal of the Board of Agriculture, 1913-1914, may be summarised as follows, the volumes given being quartergirth measurement over bark:

Taymount plantation, Perthshire, 9.69 acres, 52 years planted; average height, 88 feet; volume, 6040 cubic feet per acre; annual increment, 116 cubic feet per acre. (See Fig. 21.)

Cochwillan plantation, Carnarvon, 0.42 acres, 58 years planted; average height, 101 feet; volume, 12,040 cubic feet per acre; annual increment, 208 cubic feet per acre.

Llandinam plantation, Montgomery, $3 \frac{1}{2}$ acres, 28 years planted; average height, 66 feet; volume, 5563 cubic feet per acre; annual increment, 199 cubic feet per acre.

Tortworth, Gloucester, 1.02 acres, 43 years planted; average height, 97 feet; volume, 7316 cubic feet 


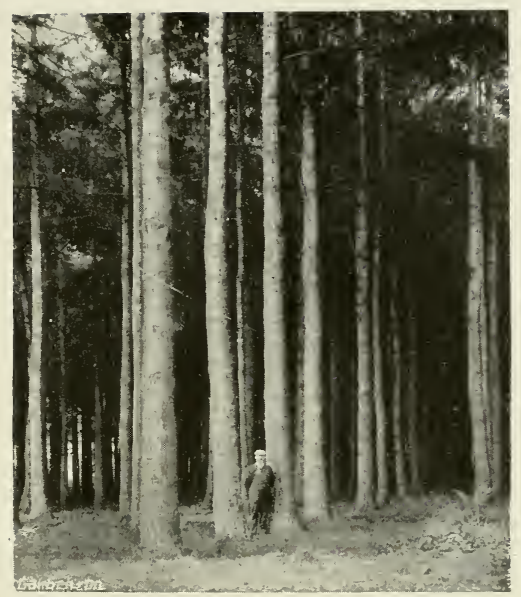

Fif: 21.-Donglas Fir Plantation at Taymount. (From liardeners' Chronicle, 20th Mareh 1915.)

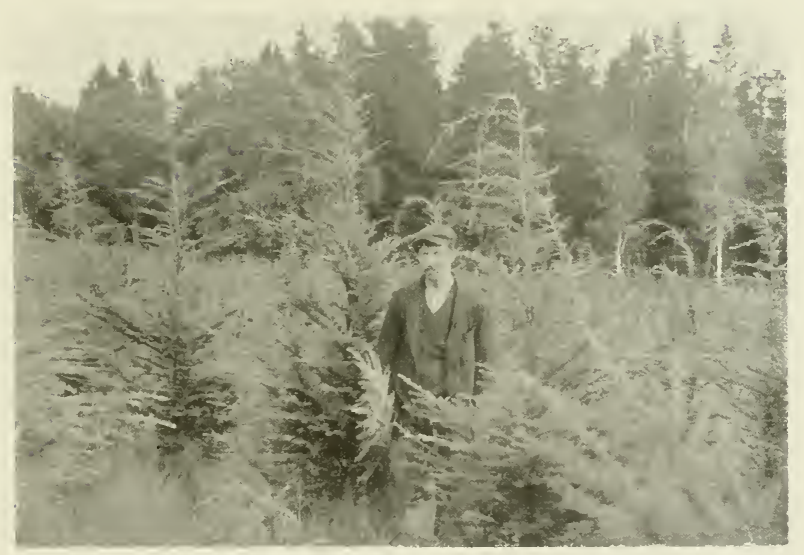

Fis. 22. - Plantation of Tsuga Allertiane at Murthly. (From Trunsuctions Royel scottisit Aiboricultural society, vol. 2i.) 


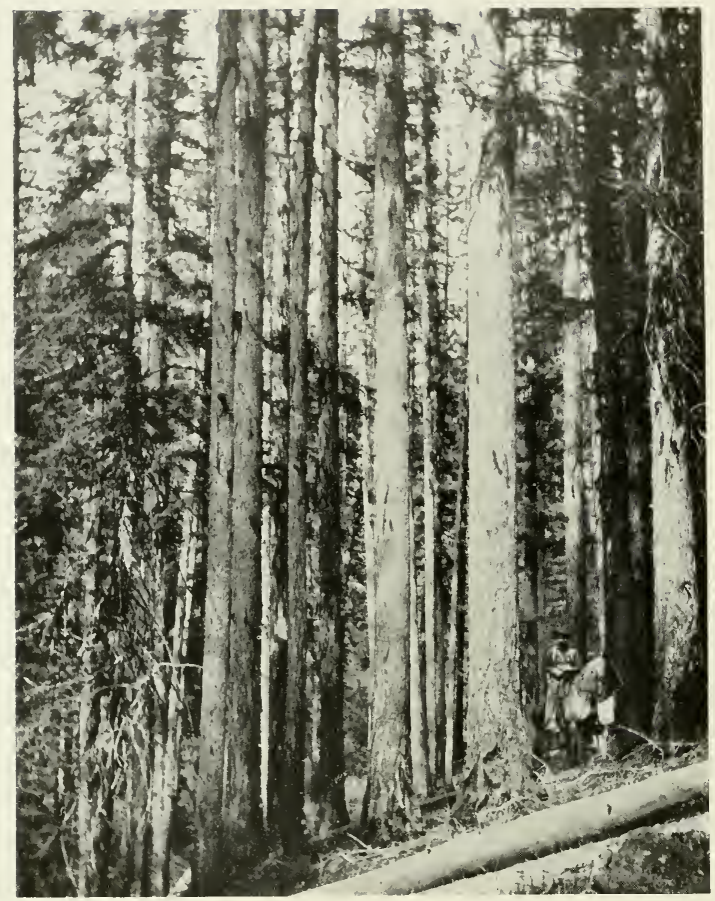

Fig. 23.-Forest of Western Larch iu Ilaho.

(From Cuuntry Life, ․3rd June 1917.) 
per acre; annual increment, 170 cubic feet per acre.

Tortworth, Gloucester, 2.26 acres, 29 years planted; average height, 66 feet; volume, 3690 cubic feet per acre; annual increment, 127 cubic feet per acre.

Dunster, Somerset, 0.84 acres, 33 years planted; average height, 74 feet; volume, 4985 cubic feet per acre; annual increment, 151 cubic feet per acre.

The volume of the Taymount plantation (Fig. 21) is much below what it would have been if the trees had not been improperly thinned. In fact, in all these plantations the conditions have not been ideal, as the trees in every case were planted much too far apart or were mixed with larch, which soon disappeared, leaving the number on the ground insufficient. The annual increment is shown to increase after the 30 th year, and the tree is in full vigour between the 50 th and 60 th year. For a rotation of 50 or 60 years, the yield may be estimated to vary from 150 to 200 cubic feet per annum per acre.

Douglas fir should nearly always be planted pure, when it is used for a main crop, as no other species will keep pace with it. Larch or spruce employed as nurses are speedily suppressed, their thinnings in that case being of no value. In such mixtures, the lower branches of the Douglas fir are not killed off soon enough, and coarse stems and knotty timber result. When planted pure at $4 \frac{1}{2}$ to 5 feet apart, the young trees soon cover the ground and suppress the grass; while their stems are cleaned before the branches become too stout. More vigorous crowns are developed than is the case when closer planting is adopted.

At Gairletter, on the Benmore estate in Argyllshire, a plantation, in which Douglas fir was planted alternately with Thuya gigantea, was very successful. The Thuya, though overtopped by its more vigorous companion, was not suppressed, and helped by its dense shade to clean the stems of the Douglas fir, while the branches were still 
slender. The Thuya also greatly improved the soil by its thick layer of decaying leaves. Natural seedlings of both species were very numerous and vigorous in open spaces. Partly blown down and partly felled, the plantation yielded, 36 years after planting, 7430 cubic feet (quartergirth measurement under bark), or an average annual increment of over 200 cubic feet per acre. In wet climates, as at Benmore, where the rainfall is over 100 inches, this mixture of Douglas fir and Thuya gigantea may be tried with success.

Douglas fir has so far been fairly free from insect or fungus attacks, but this immunity may not continue. As a precaution, extensive continuous plantations of this tree should be avoided; these should be interspersed with belts or clumps of beech. Douglas fir is of remarkable utility in what may be called interplanting, that is, filling up gaps in ordinary woods that happen to be thin and poorly stocked. It is also invaluable for converting coppice or coppice with standards into ordinary high forest, as it usually thrives on soils which carry coppice and in a short time suppresses by its vigorous growth the coppice shoots.

Home-grown timber of Douglas fir ranks in quality between Scots pine and larch; but it surpasses both in dimensions, and is more valuable than either when properly grown in dense plantations. It is equally durable with larch, the proportion of heartwood at 50 years old being about 70 per cent. It converts well, keeping straight when long sizes are sawn; and if carefully stacked it dries quickly and is not liable to warp. It is somewhat lighter in weight than spruce. Home-grown timber has been used on the Scone estate for gates, doors, and fencing; and was sold for railway sleepers and pit timber. Grown on a long rotation, the timber will be found suitable for carpentry and joinery.

Common Spruce.-In addition to the cornmon spruce, Picea excelsa, which is a native of continental Europe, there are two other species of the genus of value to foresters, 
namely, the Sitka spruce, Picea sitchensis, and the white spruce, Picea alba, both natives of North America.

The common spruce is one of our most valuable trees, but its cultivation in this country has seldom been properly carried out. It has often been planted in unsuitable mixtures upon low-lying land; and when grown pure has almost invariably been over-thinned. Its real use is to produce a large volume of timber per acre in hilly or mountainous districts, as it makes good growth at altitudes where Scots pine and larch fail. In other words, spruce is the main tree for the afforestation of the higher parts of the hill pasture zone. Spruce is a superficially rooting species, and grows upon the thinnest soil, provided there is sufficient moisture available during the growing season. At high elevations, where exposure to the wind and little depth of soil are the chief obstacles to the growth of trees, spruce will produce a considerable volume of timber.

Spruce can be raised and planted out with great ease and at a cheap rate, and it is a very hardy tree. It endures much shade, and when grown in close order covers the ground speedily, improves the soil by its layer of decaying leaves, and in due time cleans its stem, and produces timber of excellent quality. Used as a nurse for trees like larch and pine, its branches persist indefinitely, and coarse timber with large knots is the result. It should be planted pure as a rule, though in some cases, as on cold clay soil, it may be mixed with hornbeam or on dry soils with beech.

As evidence of the considerable yield of spruce at high elevations, some statistics are available in Journal of Board of Agriculture, xvii. pp. 265 and 353 (1910), and Supplement No. 9 (1912). A shelter belt on the summit of Kerry Hill in Wales, fully exposed at 1525 feet elevation, the soil being four inches of peat on yellow loam, had a volume of timber of 2880 to 3160 cubic feet (quartergirth measurement) per acre, corresponding to an annual increment of 70 to 75 cubic feet per acre. At 1400 feet elevation with less exposure, the soil being shallow loam, a plot 43 years old had a volume of 3870 cubic feet 
per acre, corresponding to an annual increment of 90 cubic feet per acre. At 1020 feet elevation, in a sheltered situation on good damp soil, the volume of a plot 43 years old amounted to 5610 cubic feet, or an annual increment of 130 cubic feet per acre.

In the Coombe Plantation at Keswick isolated trees of spruce varied in height from 48 feet at 1450 feet elevation to 35 feet on very exposed ridges at 1520 feet at 60 years old. Reckoning the average height of a plantation at 1400 feet to be 45 feet at 60 years old, the yield would be 2470 cubic feet per acre, an increment of 40 cubic feet per annum. Such a yield would justify the planting of spruce at this elevation from a financial point of view.

At Durris, in Scotland, spruce felled at 60 years old averaged 5600 cubic feet per acre in a plantation at 800 feet elevation, equivalent to an average annual increment of over 90 cubic feet per acre. In the Kilworth plantation, County Cork, at 300 feet elevation on good alluvial soil, a plot of spruce, 78 years planted, measured about 12,000 cubic feet per acre, corresponding to an annual increment of about 150 cubic feet per acre. These figures show the great yields of spruce under varying conditions of altitude. In hilly districts on suitable soil with moderate or slight exposure, spruce may be expected to yield 90 to 100 cubic feet per acre annually if grown in large areas in close order. At higher altitudes it will produce enough timber to pay for the expenses of planting; and below such high belts of spruce other plantations will flourish better on account of the protection afforded.

Sitka Spruce.-This tree is so important for the afforestation of the worst sites in our planting areas that some account of its occurrence in its native habitat will be of interest. It is a native of the Pacific Coast region from Alaska to Northern California, where it grows along the shore and inland for a few miles, ascending even in the far north to 2000 to 3000 feet altitude on mountain slopes exposed to the sea. It is unharmed either by the strong 
west wind or by the sea spray, and attains a gigantic size, rivalling in this respect the Douglas fir, which it almost equals in rapidity of growth. It grows on poorer and wetter soil than the latter tree. The timber is like white deal, is entirely without taste or odour, and is cut in Alaska and British Columbia for making butter-casks, packing-cases for fruit, wood-pulp, and pianos, as well as in ordinary house and boat building. Imported now under the name of silver spruce, its strength, stiffness, lightness, and elasticity make it the most suitable wood in aeroplane construction. The climate where it grows is similar to our own, described as "mild and uniform, with heavy rainfall, high humidity, and dense fogs; summers generally mild and winters not severe. The temperature drops to $-35^{\circ} \mathrm{F}$. towards its northerly limit; while towards the south and along the coast light frosts occur and temperature falls to zero."

Sitka spruce is extremely vigorous in growth, being only surpassed by the Douglas fir at all ages, and by the Japanese larch in the young stage. It is especially adapted for planting in difficult conditions of soil, where other species would be a failure. It grows well in wet ground, in acid peaty soil, in exposed situations, and at high altitudes. It is at home in the districts bordering on the western coast, where there is a heavy rainfall and a constant prevailing wind. It does not thrive on dry gravelly soils; but in general it is comparatively indifferent to soil, and makes excellent growth in all parts of the British Isles. It is the species that should be selected for planting in wet places in most plantations; and it should be used extensively at high altitudes in the heather moorland. The tree is excellent in form, making a beautiful straight stem (Fig. 26). The seedlings are slow in growth during the first two years, and require protection from frost. Transplanted at the beginning of the third year, they may be planted out when they have completed their third or fourth year. Larger plants, 3 to 4 feet high, can be safely moved, and should be preferred in low-lying situations liable to frost. After the Sitka spruce 
is once established it gives no further trouble; it cleans its stem more rapidly than the common spruce, but, like it, must be kept dense if timber free from knots and narrowringed is desired.

There are many enormous isolated trees of this species in parks and pleasure grounds, one of the finest being a tree at Murthly, which measured 125 feet in height and $13 \frac{1}{2}$ feet in girth in 1916, and is known not to exceed 70 years of age. Old plantations of Sitka spruce are rare, the best known being that of Strathgyle, Durris. Here 80 acres of exposed moorland, at 750 to 900 feet elevation, were planted in 1879. Larch and Scots pine failed completely. Sitka spruce flourishes to the highest point, excelling the common spruce in height, and suppressing it in mixture. At 31 years old Sitka spruce in a pure part of this plantation averaged 50 feet in height, and was estimated to contain 6000 cubic feet of timber per acre, almost an anmual increment of 200 cubic feet. In the west of Scotland, at Loch Ossian, it is growing well in young plantations at 1300 feet elevation under the worst conditions of soil and exposure, having been planted by the Belgian method, on inverted turfs. At Glenart, in County Wicklow, a plantation of larch and Sitka spruce, 43 years old, at 300 feet elevation, is very thriving. Sitka spruce here averages 75 to 83 feet in height, with a girth of 5 to 6 feet. Splendid larch alongside it are much less in size, averaging 70 feet in height by 3 to 4 feet in girth. Scots pine is only 50 feet by 3 feet.

White Spruce.-This species is of little value for producing a timber crop in this country, as under ordinary circumstances it is much inferior to common spruce. It has, however, been successfully used in the formation of shelter belts on exposed sites at high elevations in the north of England and in Scotland. It is absolutely hardy ; and at Ashgill Wood, in Northumberland, attained 30 feet in height at 1800 feet elevation on damp peaty ground, where common spruce failed to resist the cold winds. It 
is planted for shelter in wet bleak situations in Caithness, Aberdeenshire, the Moorfoot Hills of Midlothian and the Peeblesshire Hills. In Loudon's time it was planted in Connaught, where it throve in elevated positions much exposed to the wind. It can be raised in the nursery quite cheaply from seed, its treatment differing in no way from the common spruce. It may be tried in difficult situations, as on exposed ridges or in wet peaty soil at high elevations, when it is desired to give shelter to adjoining plantations below. It will ascend 200 feet higher than the limit of the common spruce.

European Larch.-This species, when grown in suitable conditions and kept free from disease by measures calculated to sustain its vigorous development, is one of the most profitable trees. It has the especial merit of yielding earlier returns than any other species, as its thinnings are saleable from the 15 th to the 20 th year onwards; and plantations are ready for felling at the end of forty to sixty years. Heartwood is formed very early; and the timber is remarkably durable and generally useful, as for gates and fencing on estates, for pitwood, poles of all kinds, and in building where strength is required. Grown properly, the larch develops a clean cylindrical stem, the slender branches being killed off before they form large knots. The larch combines high quality of timber with rapid growth, but nevertheless cannot be considered a very reliable species, as most plantations contain a considerable percentage of diseased and crooked stems. Being very light-demanding, the trees, as they advance towards maturity, do not stand dense upon the ground; and the yield of timber per acre is much less than that of spruce and silver fir, even when a plantation is quite successful. As a main-crop tree larch is unfortunately very liable to be attacked by canker, a disease caused by the Peziza fungus, which often ruins whole plantations.

Larch rarely remains healthy if grown on unsuitable soil or in low-lying situations liable to spring frost. On dry shallow soils, as on chalk, it does not thrive, and early 
succumbs to heart-rot. It suffers much from exposure to wind, and cannot therefore be planted at such high elevations as spruce. On Kerry Hill in Wales, and in Coombe Plantation, Keswick, spruce yields a fair amount of timber up to 1500 feet, while larch is useless above 1250 feet elevation. Larch should never be planted in wet ground, and when very wet spots occur in a plantation, larch should be replaced by Sitka spruce.

Larch develops superficial roots and thrives on shallow soils provided they contain a good deal of moisture. It grows well, as a rule, on the slopes of hills, where the soil is porous and well-drained. While its use in afforestation is somewhat limited, yet there are generally extensive areas where its cultivation may be attempted with success. In the hill pasture zone it is adapted for planting in valleys, in ravines, and on sheltered hillsides; and it may be carried up into the heather moor, when the situation is not too exposed or too elevated. On sandy lieaths, where Scots pine is at home, larch may be introduced wherever there is sufficient moisture; but it is not so suitable for pure sand as the pine.

Planted in mixture with other trees as a nurse, it can be early removed in the shape of thinnings, since even slender poles contain heartwood; but this practice must be carried out with discretion, as there are mixtures in common use which are very unsuitable.

Larch should never be planted pure, as this invites the attack of disease. Being a light-demanding tree, the soil is not improved by its sparse leaf-fall and feeble shade. To avert disease, vigour of growth must be fostered by improvement of the soil, which is brought about by mixing the larch with some shade-bearing tree. Beech is the best species for this purpose in most situations, though chestnut may be tried in mild climates on sandy soil, and hornbeam in cold localities on clay. Proper treatment is also necessary to keep off disease; and larch plantations must be thinned early, heavily, and often. This is necessary to remove suppressed and enfeebled trees suffering from lack of light, as 


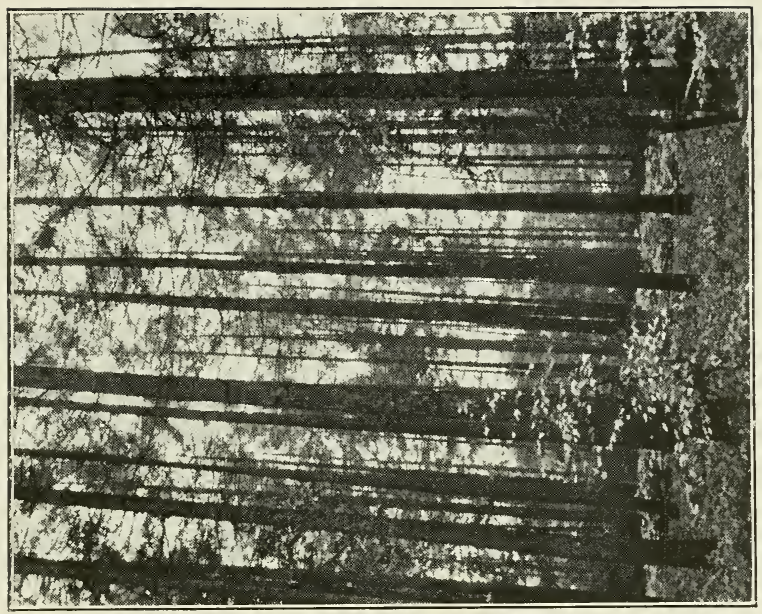

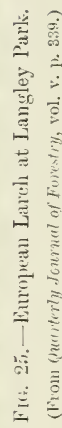

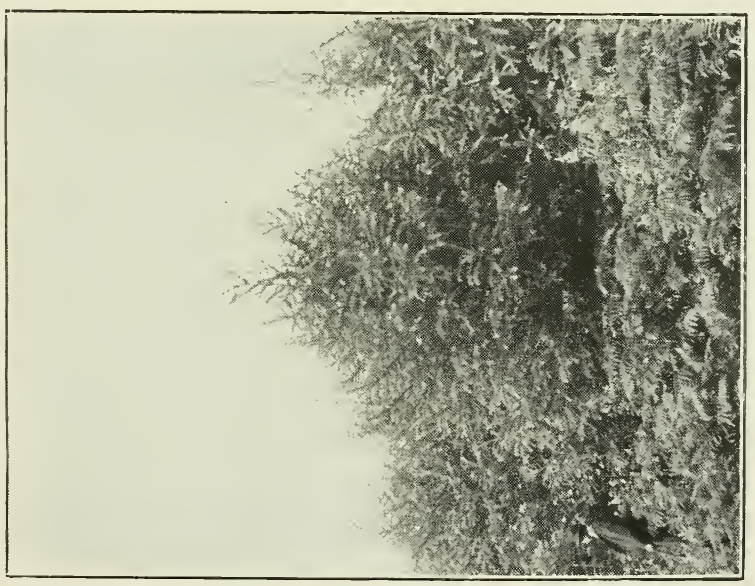

. 


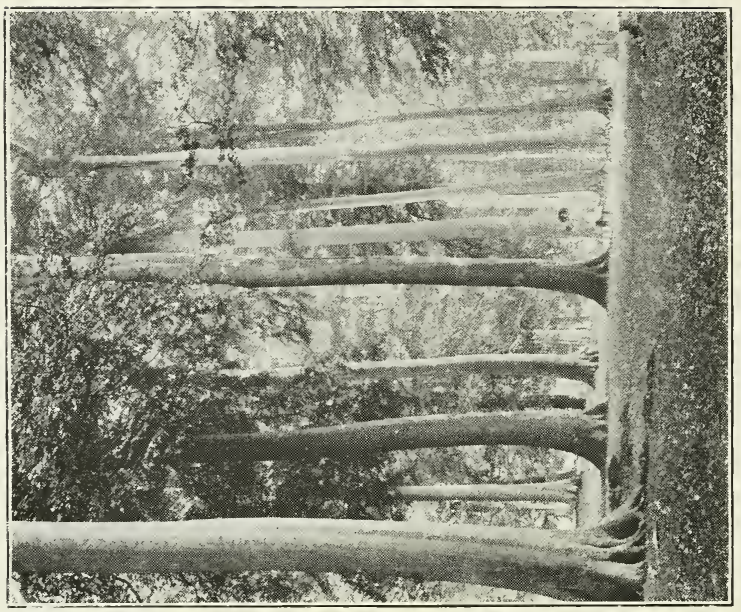

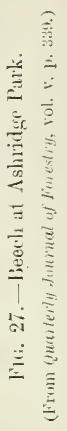

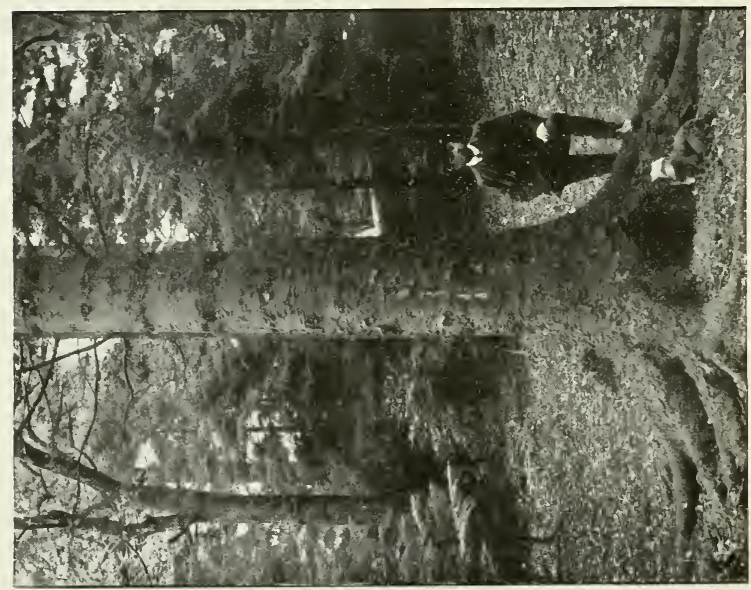

1
0 
such are invariably attacked by the fungus. It is advisable also to raise larch seedlings in the home nursery; and thus avoid the chance of importing diseased plants from a distance.

It is probable also that the choice of seed is of great importance, as bad seed produces feeble seedlings, which readily succumb to disease when planted out. The question of home-grown versus Swiss seed is not decided. The foreign seed shows, as a rule, higher germinating power, but this is probably due to more care having been taken in the gathering and cleaning of the seed. Scott-Elliot found Scottish seed to be lighter and smaller on an average than Swiss seed. If seed were gathered from the best Scottish trees, it might be as good or even surpass in quality the Swiss seed. One thing can be done, namely, to discard and burn all feeble seedlings, and only plant out strong, vigorous, and well-rooted plants.

Selected plots of larch (Fig. 25) often show very heavy yields of timber. In the Galtee Mountains, Ireland, plots measured by Mr. Waddingham gave the following results (quarter-girth measurement) :

\begin{tabular}{|c|c|c|c|}
\hline $\begin{array}{c}\text { Altitude } \\
\text { in Feet. }\end{array}$ & $\begin{array}{c}\text { Years } \\
\text { of Age. }\end{array}$ & $\begin{array}{c}\text { Volume } \\
\text { per Acre, } \\
\text { Cubic Feet. }\end{array}$ & $\begin{array}{c}\text { Average Annual } \\
\text { Increment, } \\
\text { Cubic Feet. }\end{array}$ \\
\hline & 34 & 3180 & 94 \\
600 & 44 & 3920 & 89 \\
700 & 53 & 4588 & 86 \\
480 & 53 & 4043 & 76 \\
400 & 55 & 4855 & 88 \\
400 & 63 & 3861 & 61 \\
1000 & & & \\
\hline
\end{tabular}

In the Forest of Dean, on good sandy loam at 700 feet, three plots of one acre each, 65 years old, gave yields of 4014,4081 , and 4893 cubic feet, being 61,63 , and 76 cubic feet of annual increment per acre. At Madresfield a plantation 21 years old measured 2408 cubic feet, or an annual increment of 115 cubic feet per acre.

A large grove of $2 \frac{1}{2}$ acres at Walcot, Shropshire, which, judging from the rings, was 124 years old, had 86 
trees to the acre, 125 to 135 feet in height (the tallest on record in England), with a total volume of 6430 cubic feet (quarter-girth measurement), equivalent to an average annual increment of 52 cubic feet per acre. If the thinnings, which are unknown, were added, the total yield would be enormous. (See Quarterly Journal of Forestry, iii. 357 (1909).)

No ordinary plantation would give a yield over its whole area comparable to those recorded above for selected plots. We can count, however, safely on yields of 40 to 70 cubic feet per annum per acre in successful plantations.

Japanese Larch.-This species is remarkable for its extraordinary rapidity of growth when young. Owing to this excessive vigour, it resists the attacks of Peziza, which are most liable to occur between the fifth and fifteenth year. In fact, Japanese larch may be considered to be practically immune from canker disease. It is also, for the same reason, free from serious attacks of insects, like Chermes, Coleophora, and Argyresthia, which injure the common larch. These great advantages, vigour of growth and freedom from disease, are counterbalanced by the fact that Japanese larch tends to grow crooked, and does not develop the beautiful cylindrical stems which characterise wellgrown European larch. Plantations of Japanese larch in Scotland over twenty years old show coarse, curved, and crooked stems. The timber is also not so strong as that of the common species; and when young trees are cut for pitwood the props are not so valuable.

Japanese larch bears considerably more shade than the European larch; and when planted four feet apart, it quickly covers the ground, killing the grass very soon and producing an excellent layer of humus. As the stems can be kept close together, this is one of the factors contributing to the great volume of timber produced during youth by this species. Japanese larch is also a very hardy tree, resisting spring frost better than the common species. It also grows fairly well in exposed situations, where European larch would fail completely. It makes, however, only 
feeble growth on dry soils, and was killed outright in dry situations generally by the great drought of 1911 .

One main use of Japanese larch in this country is to produce a crop of pit timber in a short term of years, say in 20 to 25 years after planting. Owing to its great vigour at the start it can also be used for planting difficult sites where other species fail, as, for example, land liable to be covered with a matted dense growth of grass, such as occurs in districts lying on the western seaboard of Scotland and in many parts of Ireland. It will succeed on poor shallow soil (Fig. 24) provided there is sufficient moisture. It has been recommended for planting areas overrun with furze and bracken; but such land if not in too exposed a situation will, as a rule, support other species yielding better timber.

Japanese larch may be used as a main-crop tree in localities where pitwood is readily saleable; and is, of course, a substitute for European larch in parts of the country where the latter suffers severely from canker. It may be looked upon as a catch-crop tree, to be planted with the idea of getting a speedy return from an area difficult to afforest. Land on which Japanese larch had been grown for a short rotation of 20 to 30 years would be in excellent condition for the planting of another species destined for growing valuable timber on a long rotation.

The growth of Japanese larch seems to be little affected by the nature of the soil, provided it contains sufficient moisture. The growth in height, while extremely rapid in youth, later drops off very considerably. The average attained by plantations in this country is about 32 feet at 16 years old from seed, 55 feet at 32 years old, and 65 feet at 37 years old. In young plantations the volume comprises much branch wood of little value. The average annual increment of plantations 32 years old may be reckoned at 100 to 120 cubic feet of timber per acre.

Western Larch (Larix occidentalis).-This is the finest of all the larches, attaining in Western Montana and the adjacent districts of Idaho (Fig. 23) and British Columbia. 
a height of 160 feet and a girth of 15 feet, and yielding timber of magnificent quality. Introduced by seed for the first time in 1903 by Elwes, followed up by larger supplies in 1908 (consequent on the visit of the writer to Montana in 1906), this larch is now being extensively tried both in this country and on the Continent. A few older trees, introduced as living plants in 1881 and 1889 , have thriven well in the poor sandy soil of the pinetum at Kew ; and during dry years are conspicuous amongst other species by their freedom from Chermes and their extremely healthy dark-green foliage. This tree would seem, then, to be best suited for a dry and continental climate. A small plantation of western larch in the Queen's Cottage grounds at Kew is healthy; but the trees, until 1917, were slow in growth, showing less vigour than European larch. In 1918 they made vigorous leading shoots of 2 to 3 feet in length, in all probability due to the grass having been entirely killed by brambles in the preceding year. Possibly they will ultimately overtake European larch in height-growth in the sandy soil and comparatively dry climate of Kew.

Hemlock Spruce.-The Western Hemlock Spruce (Tsuga Albertiana) is one of the great trees in the Pacific Coast forests of North America, ranking in vigour of growth after Douglas fir and Sitka spruce. It is a successful ornamental tree in this country, attaining in favourable conditions about 80 feet in height in 40 to 50 years; but it has seldom been used in plantations. It has given good results at Novar when used in underplanting larch.

As a forest tree it bears great shade and develops a straight cylindrical stem, on which the dead branches persist in the same way as they do on silver fir or spruce; and it must be grown in close order if clean stems are desired. The wood is of about the same value as spruce. It reproduces itself naturally in all parts of this country; and can be cheaply raised from home-grown seed. Seedlings in the nursery require to be shaded from the sun's rays and protected against frost; transplanted at the end of the 
second year, they can be planted out when three or four years old (Fig. 22). T'suga Albertiana grows well on most soils, except on chalk and stiff clay. It is at home in a mild climate, and will not bear great exposure. It suffers, however, less from wind than Douglas fir. There is little inducement to attempt its cultivation as a main-crop tree; but it may be planted as a soil-improving species in company with larch; and it can be used to fill up blank spots in open woods, as it bears a considerable amount of lateral shade.

Thuya gigantea.-This species is widely spread in western North America, where it is usually found growing isolated or in small groups amidst other species, mostly in moist valleys and along water courses, and attaining its largest size in Vancouver Island and the adjacent coast of the mainland in a humid climate. It is very vigorous in growth, but inferior in this respect to Douglas fir and Sitka spruce. It is an intense shade-bearer, rapidly covering the ground; and cleans its stem with the greatest difficulty, the branches persisting till late in the life of the tree. The wood is light, strong, and very durable.

Thuya gigantea has been much recommended for planting in this country, and has considerable merits. It is for so far a very healthy tree, free from insect and fungus attacks. It may be cheaply raised from home-grown seed, and can be planted out with the greatest ease. It is most suitable for dainp and peaty soils in humid climates; and has succeeded remarkably well on the Benmore estate, Argyllshire, where it is mainly grown (Fig. 30) in mixture with Douglas fir, and regenerates itself freely from self-sown seed. It grows also fairly well on shallow oolite and chalky soils. It can be planted pure, or in mixture with Douglas fir, larch, or Sitka spruce. The main objection to extensive use of the Thuya is that clean timber cannot be expected from it, unless it is grown on a very long rotation. It will ordinarily produce knotty poles, which are, however, very durable and useful for many purposes, as for pitwood, fencing, 
building, etc. It will scarcely yield sawn timber of any value.

It suffers from exposure to constant wind, and this limits its use to moderate altitudes, where it is especially useful for shelter on the margins of plantations (Fig. 31). At Monreith, Wigtownshire, it was killed on low-lying exposed ground by a late frost in the year after it was planted out. It is very suitable for underplanting larch that has lost its vigour and begun to suffer from disease. As a main-crop tree, its use will be limited to western localities, where the rainfall is heavy and the exposure not too great.

Lawson Cypress.-This species is remarkable for its freedom from injury from frost, insects, or fungi. It is very cheaply raised from seed, and is readily transplanted. It bears exposure to wind better than Thuya gigantea, but is considerably slower in growth. Like that species, it is an intense shade-bearer, and cleans its stem only after a long term of years. The timber of old trees in Oregon is remarkably good, but such cannot be produced here on rotations that would yield any profit. Its use, then, in afforestation in this country must be extremely limited. It grows well on peaty soils, and might be occasionally tried in patches in plantations in the wettest districts, or in underplanting.

Cupressus macrocarpa. - This species occurs wild at Monterey on the coast of California, in the same limited district as Pinus insignis, and like that species is characterised by great vigour. It grows fast, and is perfectly hardy in the milder parts of this country, as in the south and south-west of England, in Wales, on the western seaboard of Scotland, and in the maritime counties of Ireland (Fig. 29). It produces in a short period of years an immense volume of timber. Being a dense shade-bearer, Cupressus macrocarpa does not ordinarily clean its stem, as when grown pure the branches persist indefinitely, even when the trees stand close together. Mixed with beech the branches could be much sooner killed off, and more valuable 


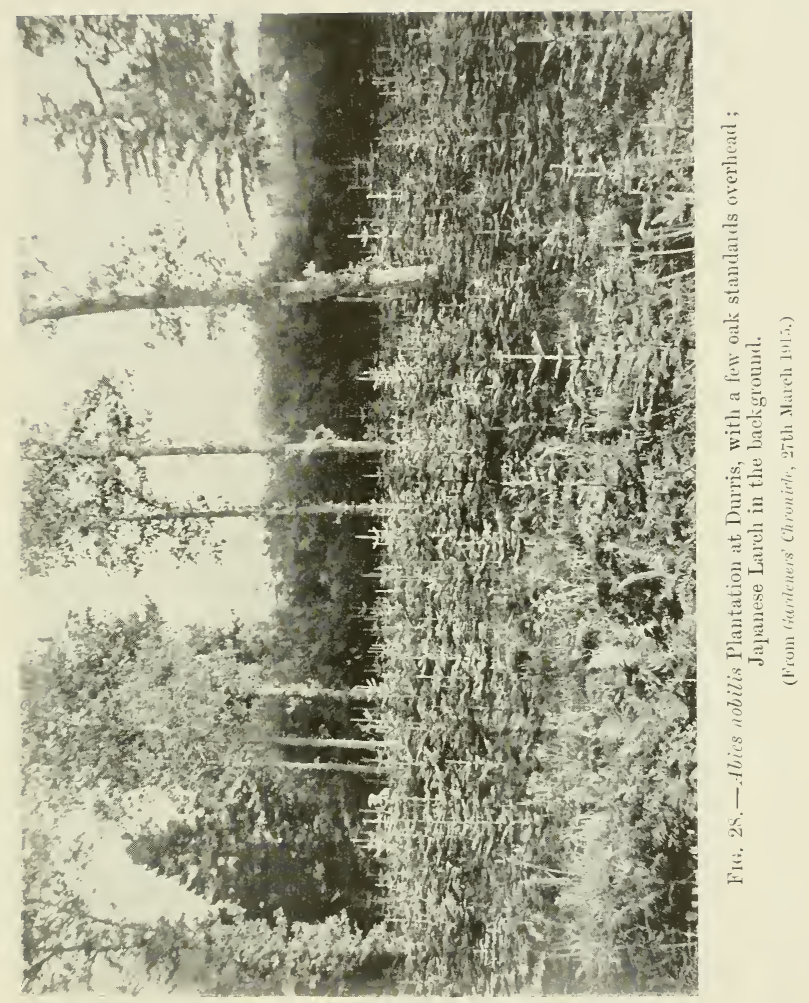




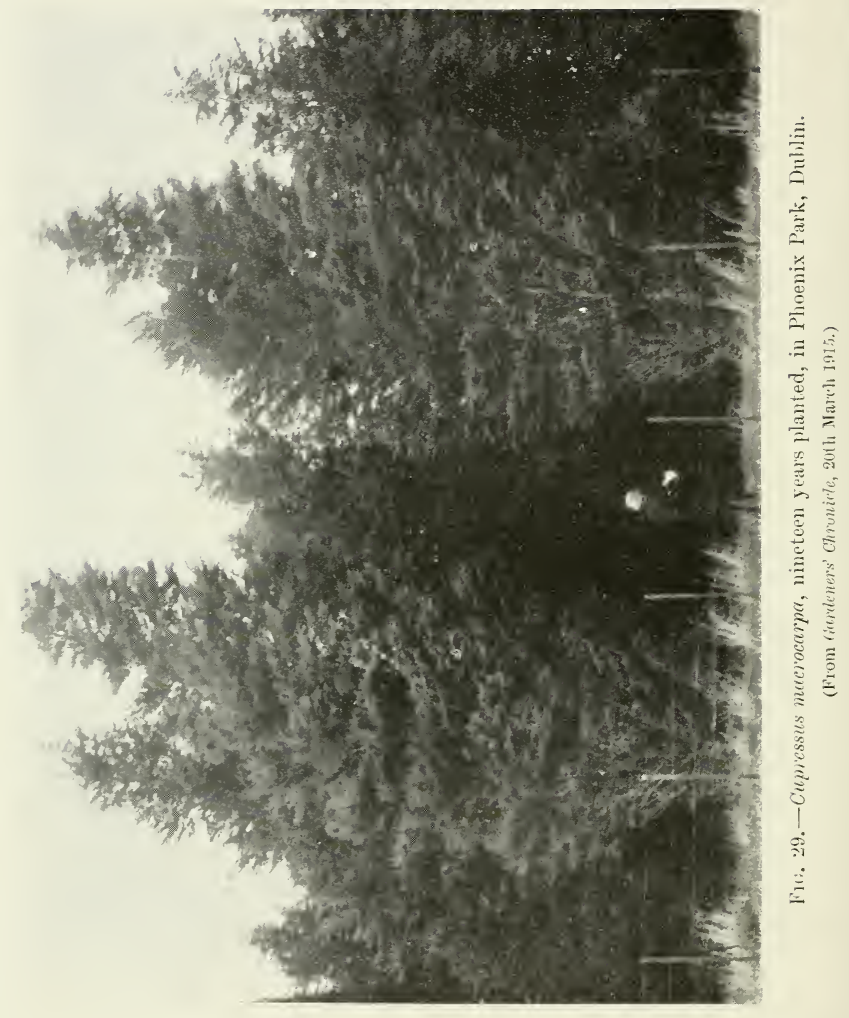


timber would be produced. The wood of isolated branchy trees is heavy, hard, strong, and very durable; and, though very knotty, has proved suitable for fencing, for building, and for pitwood. In New Zealand, a plantation of this species "has yielded posts and telephone poles of the most perfect type and durability," and a similar use might be found for trees grown in plantations in this country.

As a main-crop tree, Cupressus macrocarpa is strictly limited to localities near the sea, at a low elevation and in a mild climate. It appears to be indifferent to soil, growing vigorously even on poor shallow soil overlying chalk in Sussex. The seedlings are easy to raise, and may be planted out when a year old in situations where the surface vegetation is slight, or as two- or three-year-old seedlings, where a dense growth of grass is expected. This species is suitable for introduction in groups to fill up blanks in woodlands near the sea. Its use as a shelter belt and for hedges is well known. It is useless to attempt the cultivation of this tree in situations exposed to cold winds or to spring frosts.

\section{Broad-Leaved Trees}

Beech.-The importance of the beech in forestry cannot be over-estimated. It flourishes in most soils, except peat and wet clay; and produces, when grown in woods by itself, a large volume of timber per acre. As it bears much shade, the stems stand close together, and the dense canopy of the foliage covers the ground, so that evaporation is checked and moisture in the soil retained, while the grass is killed. Its heavy fall of leaves produces by their decay an abundant, mild, and fertile humus. Beech thus greatly improves the soil ; and is accordingly mixed with other trees, especially with species requiring much light like ash, oak, and larch, which are unable to protect the soil once they are past the young stage of growth. These valuable trees, when grown amongst beech, develop tall, straight, cylindrical stems, free from branches and knots in their lower half, the timber 
produced being increased in quantity and improved in quality by the admixture. Beech also resists wind well, and when mixed with other trees renders the crop windfirm. It is also valuable in shelter belts.

Masses of pure conifers, as of spruce, silver fir, larch, Douglas fir, etc., are liable to be attacked by fungi and insects; and it is of great benefit to intersperse amidst these uniform forests, bands and groups of beech and other broadleaved trees, which will intercept the spread of spores by the foliage, and check insects by harbouring birds. In this way, suitable spots for ash, oak, sycamore, and elm, mingled with beech, may be found throughout the conifer plantations.

Natural woods of beech oceur in the Chiltern Hills and in the North and South Downs on the chalk, and in the Cotswolds on oolitic limestone. Here beech is found thriving on shallow soil, the rock below being often covered with only a few inches of humus. The productivity of the Chiltern beech woods is well known. These are worked on the selection system, a section of a wood being taken in hand each year, and from it the largest stems are extracted by felling. On the spots from which the trees have been removed, there springs up an abundance of seedling beech, so that natural regeneration is readily effected, and no expense is incurred in the establishment of a young crop by planting. Areas occur in which beech is pure, but it is often mixed with scattered ash, whitebeam, and cherry, the latter being often abundant, and occasionally large in size. Beech, after it has passed the young pole stage, should not be kept too dense upon the ground, as with complete canopy the leaves are slow in decomposing, and produce, especially on non-calcareous soil, an acid humus. The ground remains bare of vegetation or else becomes covered with moss, Aira flexuosa, and Melampyrum, plants indicative of impoverished soil ; and the beech ceases to grow vigorously, while natural regeneration is impossible under these conditions. With a slightly open canopy, the leaves decay quickly, producing an alkaline or neutral humus; and the soil is decked with 
flowering plants, like Anemone, Oxalis, Circaea, and Asperula, with woodland grasses, like Milium and Melica, and with oak fern. The beech then grows vigorously, developing tall stems (Fig. 27), and regenerates freely.

Beech is tender to frost when young; and seedlings may often be raised with advantage under the protection of lightfoliaged trees, like birch, ash, or oak. It should not be planted in low-lying frosty situations, unless under the cover of an advance growth of birch. It will grow up to a considerable altitude in the mountains, but becomes stunted in height and ceases to produce timber in quantity. It is accordingly not of much value as a main-crop tree in plantations in the hill pasture zone. Below this zone, beech should be grown pure on poor calcareous soil, on which no other tree will thrive. On other soils, as explained above, it should be grown largely to form a matrix for valuable timber trees, like ash, oak, elm, sycamore, and larch. Most of these trees may be scattered amidst the beech, singly or in very small groups; but oak is better planted amidst beech in large groups.

Ash.-The common ash is perhaps our most valuable broad-leaved tree. It produces a strong, tough, elastic, light wood, which is essential to our industries, and cannot be replaced by any imported substitute. It grows fast, and is ready for felling at an early age, the timber being always saleable at a good price. For these reasons, ash ought to be more extensively cultivated; but there are difficulties in the successful planting of this species whicl can only be overcome by a thorough understanding of its peculiar requirements. It can rarely be grown in a wood by itself. Pure plantations of ash on a considerable scale are often attempted, but do not seem ever to be successful. Once it has passed the young stage, ash requires much light and space. Under the scanty cover of its sparse foliage, the soil deteriorates, losing its moisture and often becoming clothed with dense grass, which seriously checks the growth of the trees in height and diameter. Ash scarcely flourishes unless 
it is grown singly or in groups amidst other trees, which are capable of killiug the undergrowth of grass and of keeping the soil moist and covered with good humus. In other words, ash must be grown in a matrix of trees slower in growth, which protect the soil. A suitable species for this purpose is hazel, which is not injured by the shade of the ash. A small plantation of mixed ash and hazel made on fairly good soil at Westwick, Norfolk,. in 1906, has grown splendidly. The ash had in 1918 an average height of 36 feet, with a girth of 14 inches, while the hazel beneath was about 6 to 8 feet high.

Ash also requires for its proper development a soil rich in mineral constituents and at the same time full of moisture ; but the water must not be stagnant. It is, in fact, one of the most exacting of our forest trees, as it only thrives on moist deep soil, preferably light and loamy, and containing lime.

In England there are natural woods, in which ash is the predominant tree, mixed with oak, wych elm, hazel, hawthorn, etc., on the limestone hills of Yorkshire, Derbyshire, Westmorland, and Somerset, and on the chalk in Devon, Dorset, and Isle of Wight; but the trees are small in size and poor in quality, except where there is much moisture in the soil. These woods ascend to 1000 or even 1250 feet elevation in the Pennines.

Ash tends to spread naturally and oust other trees wherever the soil is either calcareous or contains a good deal of moisture. It regenerates itself freely by self-sown seed throughout the British Isles. Under natural conditions the finest ash would grow in deep alluvial soil in river valleys, but in this country such land has long since been monopolised by agriculture, and does not now carry forests. In the limestone districts of England, Scotland, and Ireland there are many spots with fairly deep, moist, and welldrained soil, on which would grow fine groves of ash, but most of such sites are probably taken up by the farmer or grazier. On thin, chalky soils, as in the Lincolnshire wolds, beech succeeds well in situations unsuitable for 
agriculture, and often produces fine crops of timber. Here ash mixed in small quantities amidst the beech forms very remunerative thinnings in the middle part of the life of the wood, and in all cases should be felled at from 60 to 80 years old, for if left longer it becomes unsound.

In the preliminary survey of large areas for planting, situations suitable for ash should be specially looked for. These will be found along water courses on the slopes of hills, on the sides of ravines where the water percolates through from the ground above, and in the valleys on the deep soil not far from the banks of the streams. On such sites, ash should be freely planted, mingled with other trees, like beech, larch, elm, sycamore, and oak.

Ash should never be planted on poor, dry, or shallow soils. It does not thrive on pure sand, on gravel, on dry chalk, on stiff clay, or on wet peat. At high altitudes and on unsuitable soils it remains small in size, and usually decays at an early age, producing timber of little value. It becomes black-hearted under such circumstances before it reaches fifty or sixty years old.

Ash is injured when young by late spring frosts in lowlying situations, and here requires nurses for its protection. The terminal bud is often destroyed, and forked growth results. No tree suffers more from rabbits than ash; and the cultivation of this species is impossible where rabbits are numerous, unless stringent measures are adopted to kill these pests and keep them out of the plantations.

Ash should be regularly thinned in order to give the best trees the requisite amount of light and space. Such thinnings are generally saleable, as young ash provides useful wood. Felling may take place when the trees are 60 to 80 years old or earlier; and if gradually carried out, the old stand may be replaced by the seedlings which have usually sprung up, and natural regeneration be easily effected. In other words, when a group of ash is felled, planting is rarely necessary, as the self-sown seedlings can be utilised to form the new crop. 
As ash trees approaching maturity stand far apart, the volume of timber per acre is small when compared with the yield of shade-bearing trees. Few actual measurements of well-stocked stands of ash have been made in this country; but it is the yield from thinnings that helps to make the returns satisfactory. It is doubtful if the annual increment of the volume of ash timber-final crop and thinnings being added together-ever exceeds in England over 30 to 40 cubic feet (quarter-girth measurement). Stands of white ash in the United States average at 70 years old, per acre, on first quality soils, 5600 cubic feet of timber over 3 inches in diameter, or an average annual increment of 80 cubic feet (quarter-girth measurement) per acre. The plots which gave these results were, however, fully-stocked natural stands on alluvial land, much superior to any soil on which ash would be planted in England. Though the volume in England is small, it must be remembered that there is no wood in which there is less waste than ash, as even the earliest thinnings can be used. The faster ash is grown, the better is the quality of the timber; hence the importance of selecting for this species the best sites in any planting area.

Oak.-As is well known, there are two distinct species of native oak, different in their habitats and in their sylvicultural requirements. The pedunculate oak needs for its proper development great depth of soil, associated with a large content of water; while the sessile oak is satisfied with a shallower soil containing a lesser supply of water. The pedunculate oak originally covered with forests the clays, loams, and deep sands of the southeru and midland counties of England, and is now dominant in the coppicewith-standards woods which prevail in these counties. The original pedunculate oak forests in the alluvial tracts along the great rivers disappeared at an early period. The sessile oak is now met with in Wales, in the south-west and north of England, in Scotland and Ireland, where it thrives on the thin soils which rest on the palaeozoic and igneous rocks. 
It is more a tree of the hills than the other species, ascending in the Pennines to 1000 feet. It grows fairly well on sandy and gravelly soils at moderate elevations.

Oak is a deep-rooting species, which makes poor growth on shallow soils. It succeeds best in good loam and in deep alluvial ground. It will grow on stiff clays, but not at a fast rate. It bears inundation well. Requiring considerable warmth, oak becomes stunted at high elevations, and succeeds better on southern than on northern aspects.

Oak, once it has passed the young stage, needs much space and light, and its rate of growth on all but the best and deepest soils is slow. It is late in forming heartwood, and its thinnings are of little value. The tree takes many years to mature; and when it is ripe for felling, usually in this country at 100 to 120 years, there are comparatively few stems to the acre. It can readily be seen that its cultivation holds out little inducement to private landowners, as the money return of an oak plantation is usually less than 2 per cent and payable to one's heirs. Oak should nevertheless be planted in suitable situations by the State and by Municipalities, who are bound to provide for the future needs of the community. No wood can replace that of oak. It is indispensable, as it combines every good quality, strength, size, durability, and lightness in an uncommon degree. In lowland districts, where the soil is deep enough, plantations in which oak forms a considerable percentage are advisable on land set apart for afforestation. It should never be planted pure, on account of its inability to protect the soil once it has reached the pole stage. A mixed wood of oak and beech, the latter in a proportion varying from 10 to 30 per cent, will, it is well known, produce a considerably greater volume of timber than if the oak were grown by itself. Larch may also be used as a nurse on account of its early thinnings, and on good oak soil the mixture of oak, beech, and larch will be successful. On clay soil, oak and hornbeam can be tried. English elm, chestnut, and ash may also be planted in suitable spots in any plantation, of which the main components are 
oak, larch, and beech. Oak is also a valuable tree in coppice with standards.

Of the species of oak which have been introduced into this country, the common evergreen oak (Quercus Ilex) is of no value in ordinary plantations, but is useful in wind screens by the sea. The Turkey oak (Quercus Cerris) grows faster in England than the common oak, especially on sandy soils; but its cultivation, except in shelter belts, cannot be recommended, as the timber which it produces is of little value. The American red oak (Quercus rubra) is also fast in growth on deep sandy soils in the south of England, and is worth introducing into the heaths of Surrey and Sussex, where it could be grown in groups amidst the Scots pines. The wood is strong and elastic, and of considerable value, but is not very durable when used out of doors.

Alder.-The common alder (Alnus glutinosa) is a native species, useful in wet situations, either as a large tree or for forming remunerative coppice. It bears more water in the soil than almost any other European tree; and is usually met with either pure, or mixed with willows, near streams, rivers, and lakes, on alluvial soil, the surface of which is only a few inches above the level of the ground water. Such land, if it can be drained a little, will bear good ash. Alder thrives in marshy or fenny land, in which the contained water is alkaline and rich in lime and other salts; but it does not succeed in wild undrained peat bog, full of water, poor in mineral salts, and acid in reaction. Alder on good soil bears a considerable amount of shade, and may be introduced into wet places in low-lying plantations. At high elevations wet spots, if possible, should be drained and planted with spruce, or else be left alone.

Alder may be used as a nurse for other trees in damp low-lying areas, subject to spring frosts. It grows rapidly in the young stage, and protects conifers like spruce and silver fir, which are slow-growing at first and liable to injury from frost in such situations. The alder is cut out gradually, as soon as the spruce or silver fir increases rapidly 
in height growth and gets above the frost zone. Alder has one great advantage in that it is scarcely ever attacked by rabbits, and may be planted without the expense of wire netting. It has been found useful in planting pit-mounds, slag-heaps, etc.; and this illustrates the fact that alder, while most successful in wet soils, is not confined to that situation, as it grows even in chalk.

The wood of alder is at the present time of little importance; but it is still used for making clog-soles, backs of brushes, mop and rake handles, inferior cigar boxes, hat blocks, etc. It is very durable under water, and may be used for piles.

Grey Alder.-The grey or white alder (Alnus incana) is not a native of Britain, but is widely spread on the continent, attaining its largest size, about 70 feet in height, in Sweden. It is considerably hardier than the common alder, and is remarkable for its vigorous growth in youth and its indifference to the nature of the soil. It grows on gravel and on cold clay, and flourishes in the frostiest localities. It is used in the Swiss Alps for preliminary planting in difficult situations at high altitudes, where as soon as it has formed canopy, it is underplanted with beech or silver fir, which are destined to be the final crop. It may be used for a similar purpose in this country, especially for killing grass in low-lying frosty situations. When this is effected, the grey alder may be heavily thinned, and common spruce or Sitka spruce be planted under the protection of the trees that are left. Grey alder can also be used in planting pit-mounds, gravelly borders of streams, disused quarries, etc. As a permanent crop, it is best treated as coppice on a long rotation, of about 30 years. Grey alder has been used with great success in the planting of pit-mounds in Belgium and France, but has not done quite so well as the common alder on the mounds in Staffordshire. Here it is, however, making good fertilising nodules on its roots, and is expected ultimately to thrive well. See Martineau, in British Association Report, Newcastle-on-Tyne, 1916, p. 494. 
Sycamore.-The sycamore or great maple is a native of the mountains of Central Europe, and is an extremely hardy tree. It never suffers from frost, and bears wind, whether close to the sea or inland, better than most broad-leaved trees. Quercus Ilex, however, resists the sea breeze better in Norfolk. Sycamore is rarely injured by insects or fungi, and is not attacked by rabits in most districts. It regenerates itself freely from seed. It bears moderate shade when young, but once it has passed the pole stage, requires considerable light and space, and becomes unable to protect the soil. Hence it is scarcely ever found growing pure in masses, but occurs scattered amidst other trees in continental forests. It needs a good loam for its best development, making poor growth on sand, gravel, or heavy clay. It is rather partial to limestone soils. Examples of remarkable growth of sycamore scattered amidst conifer plantations on oolite limestone in the Cotswolds are given in Quarterly Journal of Forestry, iii. 281 (1909); in one plantation, 25 years old, sycamore averaged 40 feet high and 19 inches in girth, as compared with beech, 38 feet high and $10 \frac{1}{2}$ inches in girth. It can be planted higher up in the mountains than beech, and is well adapted for growing in groups or in bands amidst the conifer masses, acting as a wind-break. It is very rarely blown down by gales, and is of considerable use in shelter belts. It should be grown in plantations wherever there are patches of loamy soil too dry for ash. Here, mixed with beech, it would develop a tall straight stem, free from branches or knots for a considerable height above the ground. Such stems, when clean and of a large size, are of great value as rollers in cotton mills. The wood of the sycamore is also used for furniture, wood ware, etc.; and the cultivation of this tree should be encouraged.

Norway Maple.-This species is more widely spread throughout Europe in the wild state than the sycamore, occurring far north in Scandinavia and Finland, and southwards in the Pyrenees and Caucasus. It is like the syca- 
more in its sylvicultural requirements, being equally hardy and wind-resisting; but it is satisfied with a poorer soil, and succeeds better in wet situations. Norway maple grows fast when young, but later slackens in growth and seldom attains a large size. There is little room for it in ordinary plantations, but it may be used along rides, and in shelter belts, especially near the sea. It is very ornamental and is well adapted for planting in the streets of towns.

Hornbeam.-This species occurs in woods in Essex, Kent, and Herts, where it is often, pure or mixed with oak, dominant on clay and loamy soils. As a rule it is a tree of small size, and only suitable for coppice. It is very hardy, not being affected by spring or autumn frosts, and grows fairly well on cold clay soils. It bears shade and improves the soil in a similar manner to the beech; and in situations unfavourable to the latter species, may be substituted for it. It can be used, for example, for planting with other trees as a nurse, in cold low-lying situations and on heavy clay soils. It may also be used for underplanting where beech would fail. The wood makes excellent fuel, but its other uses are of a minor character.

Chestnut.-The sweet chestnut (Castanea sativa), a native of the Mediterranean region, is limited for use as a forest tree in this country to mild districts. It grows best in the southern and midland counties of England, in Wales, and in the maritime counties of the south-east of Ireland. It resists wind very badly, and becomes stunted in height when grown in exposed situations. In wet soils, in soils containing more than a small percentage of lime, on stiff clays, or in frosty localities, it never thrives. Chestnut grows remarkably fast on deep sandy soils, especially those containing some loam; and succeeds on sandy gravels and on clayey loams, provided they have sufficient depth. In the south of England it flourishes on sandy soils that are too dry for larch, but when sandy soil contains a fair amount of moisture, a mixture of larch and chestnut usually does well. The great advantage of chestnut is its production of 
a large volume of excellent timber on a short rotation. The wood, moreover, is useful in all stages of the growth of the tree, so that thinnings are valuable. Chestnut coppice is also very productive. The wood is nearly equal to that of oak in strength and durability, heartwood being formed very early, while the proportion of sapwood is very small. It is extremely useful for fencing, building, furniture, etc.

In suitable soils and situations, the production of timber by this species is very great. At Witley, Worcestershire, a plantation 67 years old was 78 feet in height and yielded 3800 cubic feet (quarter-girth measurement) of timber per acre, equivalent to an average annual increment of 56 cubic feet per acre. At Highnam, Gloucester, a plantation 60 years old attained 73 feet in height and contained 3262 cubic feet per acre, equal to an average annual increment of 55 cubic feet per acre.

Old trees, when felled, are often found to be affected with ringshake, which makes the timber useless, except for fuel. This defect is generally ascribed to unsuitable soil or long rotation; but is really due to the occurrence, during the life of the tree, of an exceptionally severe winter, when, with a great fall in temperature, the tissue inside the cambium layer of the stem becomes frozen, resulting in a rupture which shows itself later as ringshake. Sound old chestnut is common in the milder parts of Ireland. At Westwick, Norfolk, ringshaken chestnut, 70 years old, when felled, showed by a count of the rings on the stump that the main shake occurred in the winter 1879-1880, noted for its very low temperature for a lengthened period. On a pond near this tree, skating was carried on from the preceding Christmas till 19th March 1880. In one butt there was an additional but slighter shake in $1874-1875$, a very severe winter; while in another, the additional shake coincided with 1854-1855, when great frost occurred. This liability to shake in severe winters makes chestnut an unreliable timber tree in the north and in all inland districts. In any case, it should not be allowed to stand too long. 
As a main crop it is ripe for felling at 60 years old; and coppice of it is cut every 15 years.

Chestnut has a very limited use in afforestation, as it can only be grown commercially in favoured spots. It can rarely be planted in the hills; and is quite unsuitable for low damp places or for situations that are exposed to wind.

Chestnut bears shade when young; but after 30 years requires much light and space. It may, however, be grown as a pure crop on suitable sites; but the stems stand far apart, scarcely exceeding 60 to 100 per acre on good soil at 60 years old. It is suitable for mixture with ash or larch, if the soil suits these species. In such mixtures, the chestnut can be cut over and kept as coppice, amongst which the ash and larch will grow well as standards. In other cases, the larch may be removed as thinnings, and the chestnut allowed to remain. In Quarterly Journal of Forestry, vi. 20 (1912), there is a description of a very successful plantation of larch and chestnut on heavy loam in Gloucestershire; the trees were planted 6 feet apart, the two species being in alternate rows.

Elm. - None of the species of elm as a rule form pure woods, but are almost invariably in the wild state scattered singly or in small groups in the broad-leaved forests. Of the various species in this country, practically only the wych elm is found naturally in woods. The other kinds are seen in hedgerows, parks, or avenues; and if, as is probable, they also are native, the original forests in which they grew have long since disappeared, giving place to farm land. All the elms bear shade in youth, but later they require considerable light and space. They need a soil of at least moderate fertility and depth, and there must be sufficient moisture. Elms are quite unsuitable for very dry soils, such as dry sand, stiff clay, or thin chalk. The various elms have marked differences in their climatic requirements, which will be pointed out in the following brief account of each species. None, however, ascend to a great elevation, and elms are not grown above the agrarian zone. 
Nevertheless, their extended cultivation is of considerable importance, as they supply a useful wood, always in demand for local purposes, and should be introduced into suitable spots in lowland plantations.

1. Wych elm (Ulmus montana) occurs wild all over Great Britain and Ireland, being a constant companion in woods of sessile oak on siliceous soils and of ash on limestone soils. It is much less exacting in its demands on soil and climate than the other species, ascending to a considerable height in the mountains, up to 1000 feet in the Pennines. It is very hardy, bears wind and exposure well, and never suffers from spring frosts. Wych elm requires much light and space, forming, when still young, a large crown with wide-spreading branches, and is difficult to grow in plantations on that account. It can, however, be planted with beech in patches in woods in hilly districts and in shelter belts which are alongside conifer plantations. It is the only elm that will thrive in the exposed and colder parts of Ireland, and in most districts of Scotland and the north of England. It is easily raised from seed which ripens in most years.

2. English elm (Ulmus campestris) is a native of southern England, growing in hedgerows, where it reproduces itself only by suckers, as fertile seeds are never borne by the tree in this country. It is common in the Thames valley, and southward to the Isle of Wight, westward to Devon, and northward in the basin of the Severn to Hereford, Worcester, and Warwick. Elsewhere in Britain and Ireland it is unknown except as a planted tree, being replaced in Cornwall by the Cornish elm. On the continent of Europe it occurs only in Spain. It requires for its development a warm climate and unexposed position; and in northern England, Wales, Scotland, and Ireland never thrives except in sheltered favoured spots. It is unsuitable for elevated land in any part of the country.

Its main value is for planting in hedges around pasture land in the southern and midland counties of England, as it does little injury to grass, and produces a considerable 
volume of timber, which is always in local demand. The wood differs from that of the other elms in its darkred heartwood, and is of especial value for making coffins, boxes, furniture, etc.; and is of service also, like wych elm, for hubs and felloes of wheels, in boat-building, and for uses under water.

The English elm is rarely planted in woods, probably on account of the difficulty of procuring it, as seedlings are unknown and grafted trees are objectionable. Suckers, however, can be dug up wherever large trees occur, and be used for planting when oak and other broad-leaved plantations are being established. It grows very fast in the south of England, and a sprinkling of it in such plantations would be advantageous. In the Forest of Dean, a mixed oak and larch plantation, aged 39 years, in which there were a few English elms, showed the following average measurements: larch, 59 feet high, 41 inches girth at breast height; English elm, 54 feet high, 37 inches girth; and oak, 40 feet high, 20 inches girth. These comparative measurements show the remarkably fast growth of English elm in good woodland soil.

3. Smooth-leaved elm (Ulmus nitens). This species is common in France, Germany, Austria, etc., where it is found wild, mixed with common (pedunculate) oak, in the forests bordering on the great rivers. Seedlings of it are imported from French nurseries under the name Ulmus campestris, but are totally different from the English elm. Smooth-leaved elm is wide-spreading in habit, and on that account is often called "wych elm" erroneously in southern and eastern England, especially in localities where the true Ulmus montana is rare or absent. Smooth-leaved elm may be planted in woods, similarly to the English elm, but will not produce as good timber or grow as fast as the latter in southern England.

4. Cornish elm (Ulmus stricta). This is a form of the smooth-leaved elm, with smaller, firmer leaves and an upright habit, which is confined to Cornwall and Devon. It succeeds better than the English elm on poor and 
shallow soils, and is remarkably resistant to wind. It is, however, slow in growth under these circumstances, producing a remarkably tough wood. Cornish elm is suitable for planting in shelter belts near the sea, and may be introduced into broad-leaved woods in Wales, Ireland, and the west of Scotland.

5. Dutch elm (Ulmus major). The origin of this tree is obscure. It is now widely spread in hedgerows in England from Cornwall to Yorkshire. It produces suckers freely, but the seed is absolutely unfertile. This elm grows fairly well in clay soil, and produces a soft wood, which is readily worked by the carpenter, and is used for purposes where strength is not required.

6. Huntingdon elm (Ulmus vegeta). This elm is of liybrid origin, and is remarkably fast in growth. So far as I know, it has never been planted as a woodland tree; but it deserves a trial in plantations at low elevations, where, mixed with beech in small groups, it would probably develop a tall, straight, clean stem. Planted in the open, it tends to be wide-spreading in habit.

Birch.-The birch, being a light-demanding tree with very sparse foliage, does not improve the soil to any considerable degree; and its production of timber per acre is meagre. Nevertheless its use in forestry is not unimportant, as it is our hardiest tree, capable of growing in the poorest soils, and reproducing itself with the greatest ease. Natural woods of birch occur at higher elevation than those of any other species, ascending in some Highland glens to 2000 feet. In the Pennines, birch forms woods up to 1250 feet, and scrub as high as 1500 feet elevation. The ground vegetation in such wood or scrub differs little from that of the adjoining hill pasture or moorland; and may consist of wiry grasses, heather, and bilberry, or be wet moor with peat plants. Birch thus occupies parts of the hill pasture and heather moor zones; and would doubtless spread over much more extensive areas, but that it is kept down by grazing, as sheep destroy the seedling trees. 
Natural birch woods as a rule contain little timber. Those in Glen Mor were estimated to produce when felled only 10 tons of wood per acre, and half a ton of twigs, the latter being used for burning the surface scale from steel plates in foundries.

The value of birch woods lies in the protection which they may afford to plantations of conifers, lying alongside them at a lower level. With the aid of birch, it would be possible perhaps to raise the timber line 200 to 300 feet higher in many mountainous districts in the British Isles. Any natural scrub or wood of birch in the vicinity of a high-lying conifer plantation should be enclosed, and be carefully preserved as a shelter belt. Birch might also be sown freely over wide bands of ground immediately above the sites of contemplated plantations at high elevations, in cases where the ground could be prepared for the seed cheaply and be enclosed at a trifling cost.

Birch is also very useful as a nurse tree, in frosty localities and in exposed situations, where damage to young conifers is to be feared; and it may be planted in advance for this purpose. Thickets of self-sown birch thinned out to five or six feet apart will serve as nurses for spruce seedlings, as the latter species usually succeeds in places where birch is able to regenerate itself freely. Birch can be very cheaply planted by the slitting method. In plantations on good sites and favourable situations, birch is a weed, and should be eliminated as soon as possible.

There are two distinct species of birch, differing in their demand on moisture in the soil ; and it is a great mistake to plant them indiscriminately. (1) Silver birch (Betula verrucosa), with glabrous twigs, pendulous branches, and very white bark, is the faster-growing and larger tree of the two species. It succeeds in a dry climate, and thrives best on a moderately moist soil, and will not grow on marshy ground or in an undrained peat-moss. It succeeds on chalk, where the other species remains stunted or dies. This species oceurs in Strathspey, Deeside, and Tayside, which is 
a distinct geographical area characterised by wild forests of Scots pine and of Betula verrucosa.

(2) Red birch (Betula pubescens), with hairy twigs and spreading or ascending branches, is found on wetter soils and in moister cliniates than the silver birch, and is the prevailing species in Ireland and the west of Scotland. It is a more rigid tree, of less size, and with a darker bark. It will grow on marshy ground and wet peat, but of course under such circumstances is only a small tree.

Birch is useful for temporary fencing, and lasts a long time when creosoted. It is also valuable for pitwood, furniture, bobbins, spools, etc.

Poplar.-Of the numerous kinds of poplar, those of interest to the forester are grey poplar, aspen, and black Italian poplar.

1. Black Italian poplar (Populus serotina) is of hybrid origin, being the result of a cross between the European Populus nigra and the American Populus deltoidea, two wild species. Black Italian poplar is always propagated by cuttings or sets, and bears male flowers. It is the latest of all the poplars in coming into leaf. Its hybrid origin accounts for its astonishing vigour. Grown in the open, it produces a larger volume of timber and comes to maturity earlier than any other broad-leaved tree in this country. In good situations, it reaches 100 to 120 feet in height in 50 or 60 years, a single stem often containing 100 cubic feet of timber at that age. It grows freely in most soils, and is extremely hardy, resisting frosts at all seasons. Except in sheltered positions, it suffers from wind in Ireland and on the western seaboard of Scotland and Wales; but in England and in the other parts of Scotland and Wales it bears a fair amount of exposure. The main value of the tree lies in its capacity for growth in situations and soils where ordinary trees fail. It succeeds in cold, wet, and undrained valleys and meadows; and thrives even on wet clay, provided the stagnant water is drained off. It grows well on shallow bogland and on gravelly soils. 


\section{TREES FOR WATER CATCHMENT AREAS 165}

With all these merits, there are difficulties in the cultivation of black Italian poplar as a forest tree in plantations, whether pure or mixed. Like all poplars, it is unable, after the first few years, to bear the slightest shade, the whole crown of foliage requiring full light; and each stem in consequence needs a large space for its proper development. Mixed with other species in a wood, black Italian poplar ultimately occupies an enormous area, overtopping and injuring the neighbouring trees. It is useless to plant it with other species, unless the latter is to constitute an underwood. It has been suggested to plant poplars 15 to 20 feet apart, and to fill up the intervals with alders; but the latter would make poor growth in this mixture unless the soil were good and deep. In a pure plantation of black Italian poplar, only the outer trees that are fully exposed to the light make large dimensions, the interior trees remaining small in diameter and of little use as timber. This might be obviated by severe thinnings ; but these would be of no saleable value, and the number of stems left standing would be so reduced as to yield only a moderate volume per acre. Large plantations of poplar are rarely seen in this country, and actual measurements are still rarer. At Benefield, Northamptonshire, $32 \frac{1}{2}$ acres of strong clay land, practically useless for agriculture, were planted in 1887 with black Italian poplar, 538 to the acre. In 1916 there were 206 trees per acre surviving, which when felled averaged 45 feet of timber length and 24 inches girth at breast height, the total volume being 1300 cubic feet (quarter-girth measurement) per acre, or an average annual increment of 45 cubic feet per acre.

Plantations of black Italian poplar contain a much smaller volume of timber than is generally expected; and in land where any of the vigorous conifers, such as Sitka spruce, Japanese larch, etc., can be grown, cultivation of poplars would be a failure financially. Black Italian poplar should be restricted to situations where it is impossible to establish conifer plantations; and in such cases the best method is a combination of meadow or pasture with poplars 
planted 15 to 20 feet apart, in single or double lines, around small fields. The crop of grass or hay is not perceptibly diminished; and a large volume of timber of considerable size and value results from the growth of the trees thus isolated.

The wood of the black Italian poplar is tough and light, resisting wear well. It is in demand for special purposes, as for brake and slipper blocks, and for polishing plate-glass in the course of its manufacture. It is used for beds of waggons and carts and for packing-cases. Being uninflammable to a considerable degree, it is suitable for flooring in factories and other buildings. It is now utilised in the making of plywood. When well seasoned it is capable of a fine polish, and is useful for making cheap furniture.

There are several other hybrid poplars which have not yet been extensively planted in this country. The best of these are: (1) Eucalyptus poplar (Populus regenerata, Fig. 32), similar in foliage to the black Italian poplar, but bearing female flowers. (2) Populus Eugenei, narrower in the crown than black Italiau poplar; it makes rapid growth on sandy soil at Kew (Fig. 33). (3) Populus robusta, with a very narrow crown, thriving at Glasnevin. This promises to resist wind better than the other poplars. The history and description of these poplars is fully given by the writer in Gardeners' Chronicle, lv. pp. 1, 46, 66 (1914), and in Trans. Roy. Scot. Arbor. Soc. xxx. pp. 14-27 (1916).

2. Grey poplar (Populus canescens). This tree is not so fast in growth as black Italian poplar; but it produces a better quality of timber, light in weight and very strong, useful for carriage building. This poplar is very hardy and may be planted along water courses and in frosty meadows. It is not suitable for plantations, but makes a splendid standard in coppice on stiff clay soil. White poplar (Populus alba) is more sensitive to wind and frost than grey poplar, and does not attain so large a size in England. In most situations grey poplar is to be preferred as being the more vigorous tree.

3. Aspen (Populus tremula). The aspen is a native tree 


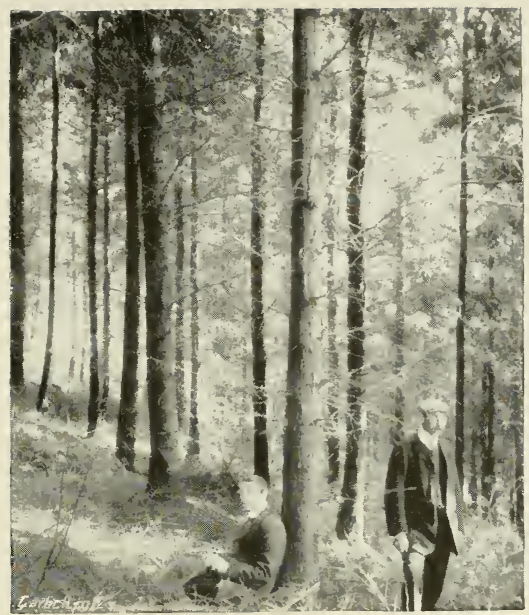

Fic. 30.-Thuyc gigantea Plantation at Benmore.

(From 'intrdeners' Chrouicle, 20th Harch 1915.)

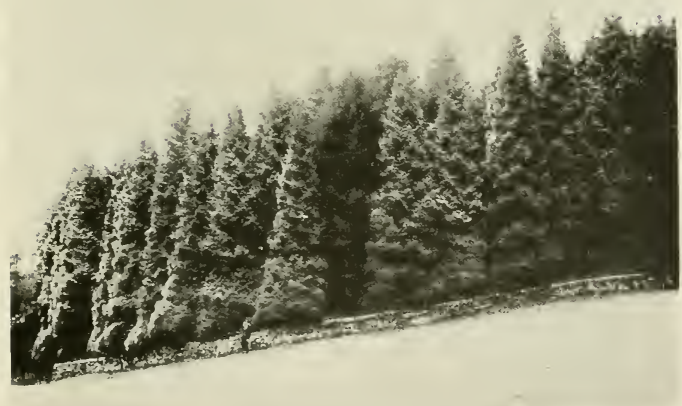

Fir: 31.-Thuya giguntea as shelter tree on plantation margin.

(From Transactions Royal Scottish Arborieultural Society, vol. 28.) 


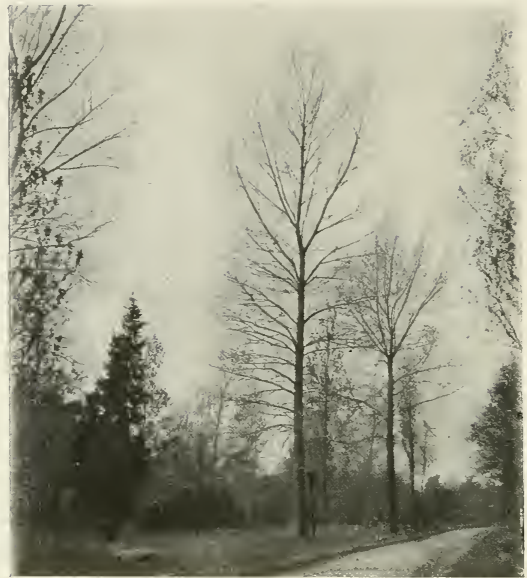

FIG. 32.-Populus rerfenerata at Glasnerin.

(From Transertions Reyal Srottish A iboriculturat sintiety, rol. 30.)

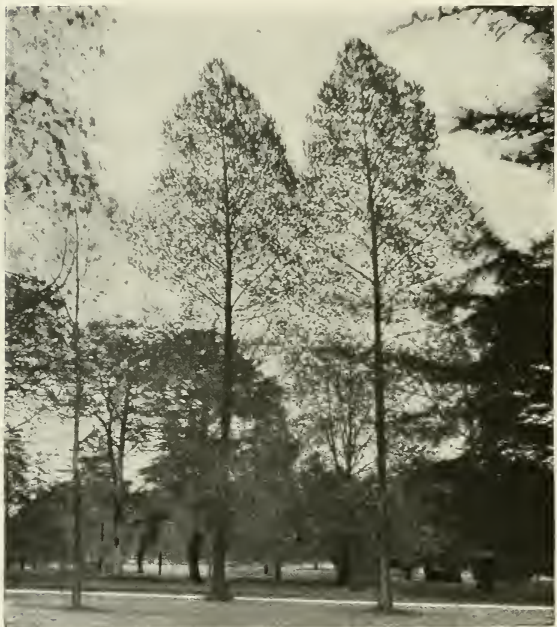

Fit: 33.-Populus Eugenei at Kew.

(From Trunsutions Royul, Srottish Arboricultural sicisty, vol. 30.) 
of small size, ascending in the Highlands of Scotland to the upper limit of trees, in Braemar to 1600 feet. It propagates itself freely by suckers, and is absolutely hardy. In very exposed situations it becomes a stunted bush. It grows on drier soils than other poplars, but produces in such conditions only a very small amount of timber. Aspen may be tried on absolutely waste ground at high elevations, where there is not much exposure; but it is doubtful if it would repay the expense of planting. In Sweden, on the best forest soil, pure aspen woods produce, at 50 years old, 2240 cubic feet (quarter-girth measurement) per acre, or an average annual increment of 44 cubic feet per acre, the stems averaging 8 inches in diameter. Of the total volume of wood at this age and size, about 40 per cent is suitable for making matches. See Meddel. Frain Statens Skogsförsöksanstalt, 1917, pp. 1205-1219.

Willow.-Three species and a hybrid are of interest to foresters :

1. Sallow or goat willow (Salix caprea). This is a small tree, rarely exceeding 30 feet in height and 1 foot in diameter, common in woods and waste places. It is often met with as natural seedlings in plantations, where it is looked upon as a weed and is speedily removed in thinnings. Sallow has been used for fixing loose and shifting soil on river embankments. The wood is useful for hurdles and fencing.

2, 3. White willow (Salix alba) and crack willow (Salix fragilis). These two species grow to a large size, and occur on the banks of rivers, streams, and lakes, being rare in the interior of woods and forests. They require much light and space, being similar in this respect to the poplars. They do not thrive at high elevations, and refuse to grow in acid peaty soil. They are useful for reclaiming and holding the soil along streams, and can be planted in marshy ground, which they help to drain. White willow grows well near the sea, and may be employed for making cheap shelter belts. Like all the willows, it is readily propagated 
by cuttings, and the expense is slight. The wood of both white willow and crack willow is tough, and indents without splintering from blows or hard usage. It can be used for brakes, carts, hurdles, roofing, and flooring.

4. Cricket-bat willow or blue willow (Salix coerulea). This is a hybrid between Salix fragilis and Salix alba, occurring only in the female sex, and invariably propagated by sets or cuttings. It is grown in the eastern counties of England, mainly in Essex, Hertford, Suffolk, Norfolk, and Cambridgeshire. Remarkably fast in growth, it produces a wide-ringed timber, light in weight and of great elasticity, which is used for making cricket bats, and sells at a high price. Trees often attain, in thirteen to fifteen years after planting, 40 to 50 feet in height and 13 to 15 inches in diameter. Cricket-bat willow should be planted only in good sites, such as rich alluvial lands by the side of a running stream, or fertile loam where there is a good supply of moisture. Ground of any kind sodden with stagnant water, and clay, gravel, and peat soils are quite unsuitable. Large sets, 6 to 10 feet long, should be used for planting. As this willow requires much light and space, and the object is to produce as quickly as possible a short stem, clear of branches for about 12 to 15 feet, the part utilisable by the bat-maker, a good crown of foliage must be preserved from the start, and the trees should be planted wide apart, the distance between them being not less than 30 feet. A full account of the cultivation of this tree was given by the writer in Trees of Great Britain and Ireland, vii. 17631769 (1913), of which an abstract by A. P. Long was published in Journ. Board of Agriculture, xxi. 289 (1914).

Black Walnut (Juglans nigra).- - It has been proposed to grow this American species in our woods, as the timber is very valuable, and splendid single trees are known to occur in many parks in the south of England. The tree is, however, exacting as regards soil and climate. It is sensitive to frost when young, but afterwards becomes perfectly hardy. It requires for its good development a considerable 
amount of warmth, and is intolerant of shade, the foliage being so thin that it seldom prevents the growth of grass underneath. It might be tried in warm sheltered spots in the south of England, Wales, and south-eastern Ireland, either grown as a standard over coppice on good soil, or introduced in small groups in deciduous woods on alluvial soil or rich loam. In raising seedlings, only nuts of American origin should be used; and as young plants are difficult to transplant, on account of their long tap-roots, it is better to sow the nuts in situ. See Quarterly Journal of Forestry, ii. pp. 138 and 167 (1908); vii. pp. 28, 32, and 225 (1913); and ix. p. 67 (1915).

Robinia Pseudacacia.-This American species, popularly but erroneously called 'acacia,' grows to a large size in parks in southern England. Its cultivation as a forest tree in woods has been urged on account of the excellence of its timber; but successful plantations of Robinia are rare or non-existent. The tree requires much light and space during its whole life, and when overshadowed rapidly loses vigour and declines. It carries a thin crown of foliage, which is unable to suppress the grass beneath. It is easily broken by wind, and suffers much in any exposed situation. It is tender to spring and autumn frosts, and requires considerable warmth in summer for its proper development. Against these demerits may be set the inducement that it thrives in poor sandy soils, provided these are deep. It, however, only attains a large size on deep sandy loam. It may be tried as a standard in coppice in the southern counties of England; but probably the best way of cultivating Robinia would be to plant it scattered as solitary trees in birch woods on sandy heaths. Shelter would thus be provided against the wind, while there would 'be enough sunlight for it to develop. Amidst birch Pobinia cleans its stem perfectly, being often free from branches up to 30 feet in fairly deep soil. It might also be introduced into chestnut plantations on sandy soil. It is easily raised from seed, and young plants should be transplanted when a year old, 
and be planted out at the end of the second or third season. The timber is valuable when of small dimensions, as heartwood is formed very early; and on this account the rotation may be short, and the trees be felled when 30 or 40 years old. The wood is very strong, and is valued for spokes of motor wheels. It is easily riven, and when used for posts, stakes, and sills, is much more durable than oak in contact with the soil. It is now employed in the United States for trenails used in fastening planks to sides of ships. Robinia suckers freely from the root, and its natural regeneration by this means is easy on sandy soil, when rabbits are excluded. See Quarterly Journal of Forestry, ii. p. 301 (1908).

\section{NOTE}

On page 145 Thuya gigantea is said to be free from fungus attacks. While these sheets were passing through the press, Dr. G. H. Pethybridge, in Quarterly Journal of Forestry, xii. pp. 93-97 (April 1919), has described a severe attack of the fungus, Keithia thujina, which recently killed outright numerous three-year-old seedlings of Thuya gigantec in a forest nursery in Queen's County, Ireland.

Sir E. G. Loder has just written to me (June 1919) that a fine plantation of 17,000 trees of this species at Leonardslee, Sussex, have been severely affected by this fungus, trees even fifteen feet high being apparently doomed. 


\section{CHAPTER X}

WATER CATCHMENT AREAS IN ENGLAND AND WALES

THE information given in the following pages is the result of queries addressed during 1917 and the present year to the town clerks and water engineers of the cities and towns which derive their water supply from catchment areas. Various publications have been consulted, especially the Parliamentary Return as to Water Undertakings in England and Wales, 1915, which states on p. xxxi: "Many undertakers rely upon water collected in reservoirs from the surface of uncultivated land, and such sources have been described in the returns as 'upland surfaces,' 'gathering grounds,' or 'drainage areas.' In some cases it is not possible to differentiate between supplies derived from upland surfaces and from rivers, streams, lakes, and springs; but it would appear that 136 local authorities, 11 joint authorities, and 20 companies depend upon gathering grounds for the whole or part of their supplies." A summary of the figures given in the following pages shows that 127 local authorities and 14 companies in England and Wales obtain their water supply from 591,336 acres of gathering grounds, of which 140,305 acres are owned by 63 local authorities and 1 water company. Owing to the stress of war time it has not been possible to make the information now given as complete as it should be, but the water catchment areas that are omitted in the present account are of little importance. It may be mentioned here that gathering grounds are not confined, as is implied in the statement of the 
Parliamentary Return, to uncultivated ground; on the contrary, a good many consist of arable land, with dwellinghouses and farm steadings.

\section{Cumberland and Westmorland}

Ten local anthorities obtain their water supply from gathering grounds aggregating 49,959 acres in these two counties. Four corporations own 11,484 acres, of which no less than 11,000 acres belong to Manchester. No planting has been done by any of the local authorities except Manchester. Mr. J. Smith Hill writes that "the water catchment areas in the Lake District could be afforested to a certain extent. There are existing plantations here and there on the hill slopes to the various lakes; but the land is generally owned by many proprietors, and would be troublesome to acquire on account of the sheep industry. There are often rights of pasturage, called 'stints,' on the fells attached to each farm lower down, so that afforestation on an extensive scale would be a difficult matter, as the rights would have to be bought out, and there would be many people to deal with. The purchase of Thirlmere, where there was only one owner, was very costly to Manchester."

Thirlmere catchment area of 11,000 acres, owned by Manchester Corporation, with a good afforestation scheme, is fully described on pp. 95-98.

Carlisle obtains its water supply from Geltsdale, an area of 7000 acres, of which 4000 acres are above 1500 feet elevation, 1500 acres between 1250 and 1500 feet, 1000 acres between 1000 and 1250 feet, and 500 acres under 1000 feet. The area, which is all grazing land, is not owned by the Corporation, and no scheme for planting trees has been contemplated.

Aspatria, Silloth, and District Jolnt Water Board obtain their supply from an area of 2251 acres at 620 to 2000 feet altitude, in the parishes of Ireby High, Ireby Low, and Uldale, at the head waters of the river Ellen, on the north 


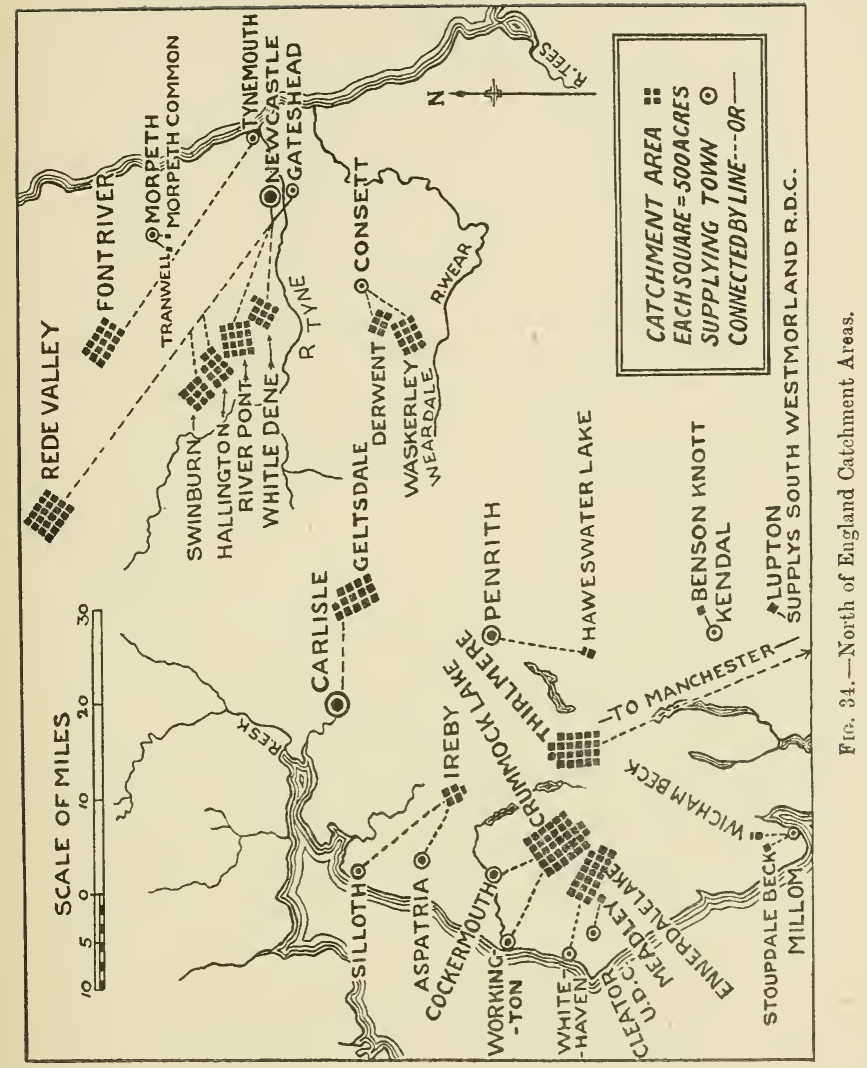


side of Skiddaw, with an intake at Chapelhouse. The area, which consists of bare sheep-runs, does not belong to the Board, who have only rights of diverting and impounding water.

Workington, which gives a supply in bulk to Cockermouth, obtains its water from Crummock Lake, with a catchment area of 16,000 acres, situated between 323 and 2791 feet elevation, of which the Town Council own only 307 acres. The watershed is mostly mountain or moorland of a rocky nature, with very few buildings and little arable land. On the lower part of the watershed, from which compensation water is taken, there are more farmsteads and arable land. Close to the lake there are no buildings, and practically no contamination occurs, as is proved by chemical and bacteriological examination. The water is not filtered, but is simply passed through copper screens at the intake.

Whitehaven obtains its water supply from Ennerdale Lake, with a catchment area of 10,000 acres, situated between 369 and 2900 feet elevation, and comprising 480 acres of arable land (including 380 acres of meadow and pasture), 9420 acres of hill grazing and moorland, and 100 acres of plantations. The Corporation own $\frac{1}{4}$ acre only. There are ten habitations on the area, nine of which are at such a distance from the lake that they are not likely to cause any contamination. In the case of the only one built on the margin of the lake, the sewage is treated. The supply, which is not filtered, is said to be one of the softest and purest in Britain, being equalled only by that of Loch Katrine.

Cleator Moor Urban District Council obtains its water supply from Meadley reservoir, Kinneside, with a catchment area of 600 acres on Cleator, Kinneside, and Ennerdale Fells, between 500 and 1200 feet elevation, all hill pasture and moorland, without any arable land or plantations. The gathering ground, of which 26 acres are owned by the Council, has no habitations or farm steadings upon it. The 
water is filtered, and "the ground is examined to see that there are no dead sheep lying on it. Nothing else is required."

Penrith Urban District Council obtains its water supply from Haweswater Lake, with a catchment area of 750 acres, between 1383 and 2300 feet elevation, all hill pasture and moorland, grazed by mountain sheep only, and without habitations or farmsteads. Filtration is not necessary. The Council owns none of the catchment area.

Kendal has a water catchment area of 300 acres, at Benson Knott, the storage reservoir being Fisher Tarn, $2 \frac{1}{2}$ miles east of the town. The area, of which 60 acres are owned by the Town Council, lies between 700 and 1000 feet altitude, and is "upland moorland, with some grazing and arable land, free from habitable houses and farms." The water is not filtered. See Trans. Liverpool Engineering Soc. xxiv. (1903).

Millom Urban District Council obtains its water supply from (1) Whicham Beck, with a gathering ground of 686 acres on Swinside Fells, between 275 and 800 feet elevation, and (2) Stoupdale Beck, with a gathering ground of 372 acres on Whitcombe Fells, between 400 and 1280 feet elevation. Of the total area of 1058 acres, the Council owns 117 acres adjoining the storage reservoir at Baystone Bank, Whicham, which comprise one sheep farm of 12 acres, 100 acres of hill pasture and moor, and 5 acres of plantations. The sewage of the farmhouse is diverted into a cesspool, frequently emptied. The rest of the gathering ground, 941 acres, is rough rocky mountain pasture.

South Westmorland Rural District Council obtain their water supply in part from an upland surface of 500 acres at Lupton, where there is a reservoir. The water is not filtered. Information about ownership, etc., has not been obtainable. 


\section{Northumberland and DURham}

Two local authorities and two private companies obtain their water supply from gathering grounds in these two counties. The gathering grounds have a total extent of 41,197 acres, of which 110 acres are owned by Morpeth, and 3300 acres by the Newcastle and Gateshead Water Company.

Morpeth obtains its water supply in part from (1) a gathering ground of 110 acres on Morpeth Common, between 209 and 260 feet elevation, which is owned by the Corporation; and (2) a gathering ground of 194 acres at Tranwell, between 300 and 350 feet elevation, not owned by the Corporation. The total area of 304 acres comprises 219 acres of hill pasture and 85 acres of plantations, and is free from habitations or farm steadings. No precautions, other than filtration, are carried out, except that a pipe is laid under the bed of the small stream leading the water into the storage reservoir at Tranwell. All the water collected on Morpeth Common is carried by under drainage direct to a filter bed.

Tynemouth obtains its water supply from the Font impounding reservoir, with a gathering ground in the Font valley, Northumberland, of 7360 acres, situated between 611 and 1447 feet elevation, the highest point being Tosson Hill. The Town Council own only the site of the reservoir and the margin around it. There are four farm steadings and houses upon the area, which formerly had some woodland upon it, but there are now only a few living trees standing. The proportion of arable land is not stated. No special precautions are taken against contamination on the gathering ground, but the water is passed through filters.

The Newcastle and Gateshead Water Company, which supplies Newcastle-upon-Tyne, Gateshead, and adjacent districts in Northumberland and Durham, obtain their water 
supply from the following catchment areas in Northumberland :

1. Rede Valley gathering ground, 9848 acres, comprising the head waters of the river Rede, east of Carter Fell (1813 feet elevation), and feeding Catcleugh reservoir. About one-third of the area, say 3300 acres, are owned by the Company.

2. Swinburn gathering ground, 4462 acres, with Little Swinburn and Colt Crag reservoirs, near Barrasford on the North Tyne. The Company own only the reservoir sites and fringes of land adjacent.

3. Hallington gathering ground, 5453 acres, with West Hallington and East Hallington reservoirs near Colwell. Erring Burn drains into a catchwater which is treated as part of this gathering ground. The Company own only the reservoir sites and fringes.

4. Whittle Dene gathering ground, 4770 acres, with seven reservoirs. The Company own only the reservoir sites and fringes.

5. The Company also obtain some water from the river Pont at Matfen, with a catchment area of 7950 acres, not owned and only partially used by the Company.

The catchment areas, exclusive of the river Pont area, which is only partially used, aggregate 24,533 acres, and are largely hill pasture. The amount of arable land and number of habitations and farmsteads on the various gathering grounds have not been ascertained. The water is passed through sand filters, and is reported to be of excellent quality, withont any action on lead.

Weardale and Consett Water Company obtain their supply from two catchment areas in Durham :

1. River Wear gathering ground, 6000 acres, between 700 and 1650 feet elevation, supplying Waskerley reservoir (1172 feet O.D.) and Tunstall reservoir (720 feet O.D.), and comprising 5315 acres of hill pasture and moor, 5 acres of gardens, and 680 acres of plantations.

2. River Derwent area, 3000 acres, between 1000 
and 1600 feet elevation, supplyiug Hisehope reservoir (1128 feet O.D.) and Smiddy Shaw reservoir (1120 feet O.D.), all hill pasture except one acre of gardens.

The Company own or hold on perpetual lease from the Ecclesiastical Commissioners the sites of the reservoirs only, namely, 206 acres (102 owned, 104 leased) on the Weardale area, and 135 acres (leased) on the Derwent area. On the Weardale area there are 6 farmsteads and 13 houses, and on the Derwent area 2 houses only. The drainage from the farmsteads is, by agreement with the landowners, diverted on to meadowland. The water is filtered. For further particulars see R. Askwith, M.Inst.C.E., in Trans. Inst. Water Engineers, xiv. $60(1910)$.

\section{LANCASHIRE}

Twenty-one local authorities obtain their water supply from gathering grounds with a total extent of 66,412 acres, of which 27,085 acres are owned by 12 corporations. The chief authorities owning water catchment areas in Lancashire are Liverpool, Bolton, Bury, and the Heywood and Middleton Water Board. Liverpool has planted 1300 acres on the Rivington area. Bury has not been very successful with an afforestation scheme which was begun in 1908 . Planting on the Bolton areas has been a failure. There are woods of small extent on the Fylde, Fulwood, and Preston gathering grounds. The moorlands of Lancashire, owing to their exposure to the west wind and the prevalence of smoke from the neighbouring manufacturing towns in some districts, are not favourably situated for tree-growth. The degree to which the air of the densely populated part of Lancashire is fouled by smoke, and the consequent deleterious effect on vegetation, are not fully recognised. The whole of southern Lancashire (the half of the county lying south of the river Ribble), and especially the district between Blackburn, Accrington, and Burnley on the north, and Wigan, Bolton, and Manchester on the south, are far too much affected by smoke to allow of anything 


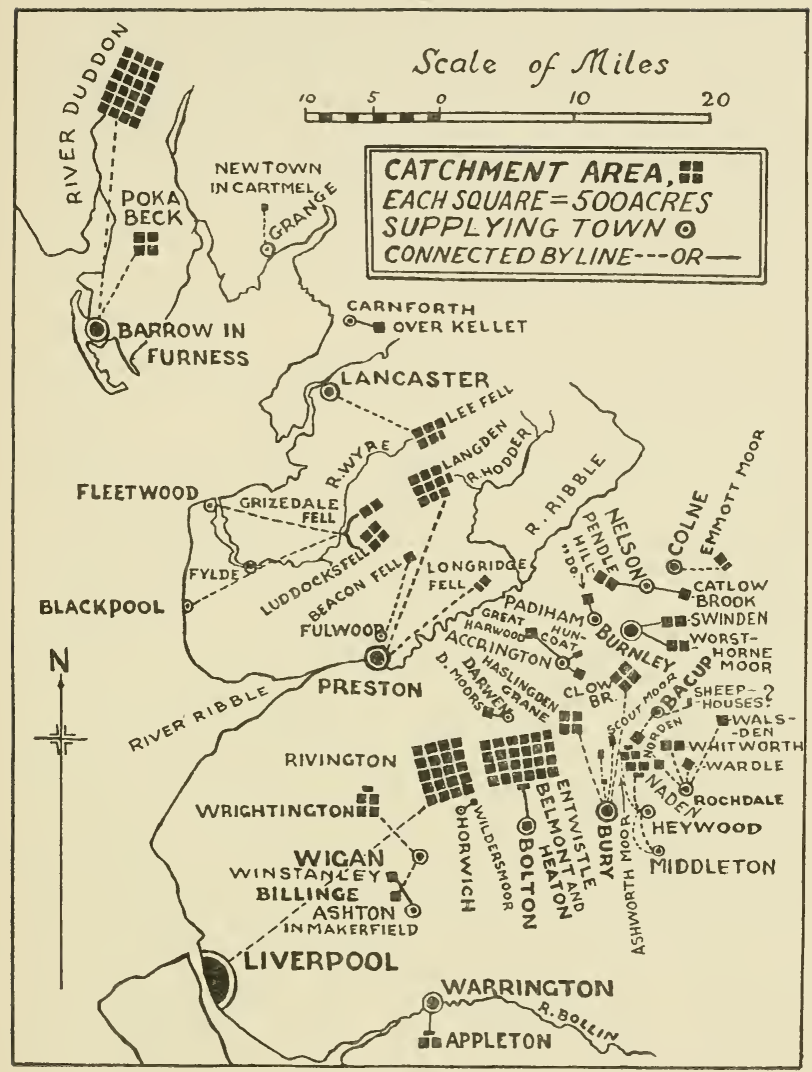

FIG. 35.-Lancashire Catchment Areas. 
approaching normal tree-growth. As is well known, the smoke of southern Lancashire and of the West Riding of Yorkshire affect to some extent the whole of the north of England. The bad effect of smoke on trees must be taken into account in all afforestation schemes of areas in or near these manufacturing districts. See our notes on effect of smoke, pp. 45 and 57, and J. A. Wheldon and W. G. Travis in Journ. Linnean Soc. (Botany), vol. xliii. pp. 89-95 (1915).

Rivington catchment area of 10,000 acres, owned by Liverpool Corporation, with 1300 acres of plantations, is fully described on p. 94.

Barrow in Furness obtains its water supply from two catchment areas, as follows:

1. Poaka Beck and Pennington reservoirs, at 505 feet elevation, have a gathering ground extending up to 1000 feet elevation; and Harlock reservoir at 610 feet elevation has a gathering ground ascending to 1025 feet elevation. The total area is 1980 acres, of which only about 135 acres are owned by the Corporation, and of this 92 acres are water. There are a few plantations on the gathering grounds (not on the Corporation land), most of which is moorland covered with heather and bracken. The plantations appear to have been much neglected, though there are some fair-sized trees among them. The average annual rainfall is 53 inches.

2. The watershed of the river Duddon, above the intake, $7 \frac{1}{4}$ miles from its source, is 12,000 acres, of which the Corporation own only about 100 acres, and of this 85 acres are water. There are on the lower levels of the gathering ground several woods and plantations with fair-sized trees in them which appear to thrive well. The upper levels consist of fell and moorland, used for sheep grazing. The average annual rainfall is 90 inches. About $4 \frac{1}{2}$ miles above the intake, Seathwaite Tarn, the level of which was raised 20 feet by a concrete wall, has now an overflow level of 1230 feet, and forms a large compensation reservoir. The highest point of the watershed draining into it is 
2550 feet altitude. See Proc. Inst. Municipal and County Engineers, vol. 36, p. 447 (1910).

Grange Urban District Council obtains its water supply from a gathering ground of 120 acres at Newton in Cartmel, Lancashire, between 600 and 800 feet elevation. The Council owns 100 acres. The gathering ground is all moorland, and free from habitations except the cottage of the attendant, the sewage of which is diverted by a pipe off the area. There are two storage reservoirs at Newton in Cartmel, and the water is filtered.

Lancaster obtains its water supply from moorland springs in Lee Fell, Dunkenshaw Fell, and Tarnbrook Fell, in the north-eastern part of the watershed of the river Wyre. The catchment area is said by Mansergh, in Journ. $R$. Soc. Arts, vol. 32 , p. 872 (1884), to be 2700 acres in extent, at 850 to 1800 feet altitude, being scanty herbage on millstone grit with numerous springs, so that the water supply is perfect. As this supply is not derived from surface water, this catchment area is not included in the total 66,412 acres of gathering grounds of Lancashire, on p. 178.

The Fylde Water Board, which supplies Blackpool, Fleetwood, and other places in Lancashire, has two catchment areas in Bleasdale in the river Wyre watershed:

River Calder area, intake at Luddock's Fell, 2000 acres, at 628 to 1520 feet elevation, without any plantations; no part is owned by the Board.

Grizedale Brook area, intake at Grizedale Fell, 1083 acres, at 395 to 1325 feet elevation. The Board owns 150 acres, including the sites of two reservoirs and some land around them. There are about 50 acres of plantations in the valley near the reservoirs.

The whole gathering ground is rough moorland, uncultivated, and free from pollution, there being only one small farm upon it. The water, which is stored in the Grizedale, North Barnacre, and South Barnacre reservoirs, is passed through straining chambers and sand filters. 
Fulwood Urban District Council obtains its water supply from an upland surface of 330 acres on Beacon Fell, Goosnargh, between 500 and 872 feet elevation. It is all hill pasture and moor, with one farmstead upon it. The Council owns 300 acres. The water is not filtered.

Carnforth District Waterworks Company obtain their supply from the Swarthbeck Stream at Over Kellet, where there is a storage reservoir, with a catchment area of about 400 acres, between 360 and 422 feet elevation. The Company own only 3 acres of the area, which comprises 60 acres of arable land, 280 acres of hill pasture and moor, and 60 acres of plantations. There are 3 habitations on the gathering ground, and no special measures are taken against contamination. The water is filtered.

Preston obtains its water supply from two catchment areas, both in Lancashire, aggregating 5465 acres in extent :

1. River Hodder Watershed, 4765 acres, comprising Langden Valley, 3795 acres, between 525 and 1707 feet elevation, and Hareden Valley, 970 acres, between 471 and 1500 feet elevation.

2. River Ribble Watershed, Longridge Fell, 700 acres, comprising Cowley Brook area, 300 acres, between 620 and 1016 feet elevation, and Dean Brook area, 400 acres, between 600 and 1125 feet elevation.

The areas are not owned by the Corporation, who have only acquired the water rights. There are no plantations of trees in the Langden or Hareden Valleys; but in Cowley area there are 130 acres, and in Dean area 250 acres of plantations. The water is filtered. The watersheds are all moorland, without habitations, except one house in the Dean Brook area, the drainage of which is specialiy dealt with.

Colne obtains its water supply in part from the river Laneshaw, about three miles east of the town, with an upland gathering ground on Emmott Moor, 780 acres in extent, at 660 to 1430 feet elevation. The Corporation 
practically own none of the area, which is without any plantations, most of it being "rather bare and above the tree-line." The water is filtered, and in times of floods, etc., the keeper of the Laneshaw reservoir turns the intake down the bye-pass channel, so as to keep the water out of the reservoir.

Nelson obtains its water supply from two gathering grounds :

1. Catlow Brook area, east of the town, 400 acres, between 943 and 1300 feet elevation, draining into Coldwell reservoir, and

2. Pendle Hill area, west of Nelson, 1100 acres, between 837 and 1850 feet, with two reservoirs at Ogden.

The total area, 1500 acres, is entirely hill pasture and moor, without plantations or arable land. The Corporation own 137 acres, situated above Coldwell reservoir, which was purchased in 1916 in order to prevent manuring of the land. The water is filtered.

Padiham Urban District Council obtains its water supply from two upland surfaces, aggregating 440 acres on Pendle Hill, and situated between 800 and 1500 feet elevation. The area, none of which is owned by the Council, is hill pasture grazed by sheep, and is without plantations or farmsteads. The only precautions taken are constant inspection of the streams. The water, which is not filtered, is stored in the Pendle Hill reservoir.

Burnley obtains its water supply from two gathering grounds: Cant Clough reservoir, Worsthorne Moor, 1050 acres, between 800 and 1400 feet elevation; and two reservoirs at Swinden, Extwistle Moor, 985 acres, between 924 and 1400 feet elevation. The total area, 2033 acres in extent, is entirely hill pasture and moorland, free from farmsteads and habitations; and no part of it is owned by the Council except the sites of the reservoirs. The water is filtered, and no other precautions are considered necessary against contamination. 
Accrington District Gas and Water Board obtain part of their water supply from three gathering grounds:

1. Mitchell's two reservoirs, Accrington, 460 acres, between 977 and 1200 feet elevation.

2. Burnley Road reservoir, Huncoat, 250 acres, between 634 and 850 feet elevation.

3. Dean Clough reservoir, Great Harwood, 540 acres, between 504 and 745 feet elevation.

The total area, 1250 acres, is made up of 1198 acres of hill pasture and moor, 45 acres of arable land, and 7 acres of plantations; and on it there are $12 \mathrm{dwelling}$-houses and farmsteads. The Board own 426 acres (including 60 acres of water) on Dean Clough area, 17 acres on Burnley Road area, and 82 acres (including 28 acres of water) on Mitchell's area. The water, except that of the Burnley Road reservoir, is filtered. The precautions taken against contamination are constant inspection of the land by water bailiff, storm-water reservoirs at the inlets, and catchwater drains around the reservoirs.

Bury and District Joint Water Board obtain their supply from five gathering grounds, as follows:

1. Haslingden Grane area, with Ogden, Calf Hey, and Holden Wood reservoirs, 2185 acres, between 650 and 1250 feet elevation.

2. Rawtenstall area, with Clow Bridge and Clough Bottom reservoirs, 2036 acres, between 900 and 1400 feet elevation.

3. Scout Moor area, Edenfield reservoir, 244 acres, between 650 and 1500 feet elevation.

4. Walmersley area, Gin Hall reservoir, 163 acres, between 450 and 750 feet elevation.

5. Shuttleworth area, Harden Clough and Cross Bank reservoirs, 200 acres, between 650 and 950 feet elevation.

'The whole of the gathering grounds, 4828 acres, are owned as freehold by the Water Board. The three principal areas are mostly moorland and hill pasture, the 
amount of arable land on the Haslingden Grane area being 78 acres, and on the Clow Bridge area 60 acres only. About one-half of the total extent of the gathering grounds are above the 1000 feet contour line, the other half being below it. The late Professor W. R. Fisher made a report in 1908 and drew up proposals for planting 700 acres in all on the Haslingden, Clow Bridge, and Scout Moor areas. The moors occupying the high altitudes, owing to the constant practice of burning the heather, are now covered with coarse tufted grass, of scarcely any value for cattle or sheep, and, owing to the depth of the peat and the high elevation, cannot be planted with trees. Just below the moors there are rough sloping lands, between 800 and 1000 feet altitude, which in Professor Fisher's opinion could be planted with trees. Lower down the slopes there are numerous little dairy farms with excellent buildings. The plantation of the slopes above these farms would be of great value as shelter for the stock upon them. He recommended spruce, larch, beech, sycamore, and ash as suitable species. The cost of fencing against stock and the small size of some of the planting areas recommended were uneconomic features in his afforestation scheme. Where, as in some parts, the smoke nuisance existed, only broad-leaved trees were recommended to be used. The use of basic slag, kainit, and carbonate of lime was advocated for peaty soil on which spruce was to be planted. In accordance with Professor Fisher's advice, 158 acres of plantations were made between 1909 and 1915 . The results have been very varied, particularly in the case of over an altitude of 1000 feet, where the number of trees killed has been very considerable, doubtless owing to their exposed position.

Only some of the water is filtered, namely, that from the Clow Bridge and Clough Bottom reservoirs. See W. R. Fisher, Report on Planting of Trees in the Watersheds of Bury and District Joint Board, 14 pp. and maps (Bury, 1908); and A. P. Greenfell in Quarterly Journal of Forestry, iii. 41 (1909). 
Bacup obtains its water supply from two gathering grounds: (1) Cowpe reservoir, on Cowpe Brook, with a catchment area of 593 acres, between 1020 and 1400 feet elevation, of which 500 acres are owned by the Town Council. These 500 acres are made up of 458 acres of moorland, 13 acres of ploughed land, 26 acres of meadow, and 4 acres of plantations. A wall has been built to keep cattle off the gathering ground, on which there are occupied farmsteads and dwelling-houses. (2) Sheephouses reservoir, with a gathering ground of 150 acres, of which the Town Council own only the water rights. The water of both reservoirs is filtered.

Rochdale obtains its water supply from four gathering grounds as follows :

1. Whitworth area (Cowm reservoir), 964 acres, at 816 to 1450 feet elevation.

2. Norden and Whitworth area (Spring Mill reservoir), 558 acres, between 771 and 1450 feet elevation.

3. Wardle and Whitworth area (Syke reservoirs), 497 acres, between 787 and 1300 feet elevation.

4. Walsden area (Walsden reservoir), 400 acres, between 987 and 1425 feet elevation.

The total area, 2419 acres, is all hill pasture and moor, except 7 acres of plantations. The Corporation own the site of the Cowm reservoir, 78 acres of the Norden area, and 320 acres of the Walsden area. There are 20 sheep farms and cottages on the Whitworth, Norden, and Wardle areas. The water is filtered and regularly analysed. The gathering grounds are frequently inspected, and water of a doubtful character is diverted. The sewage of the farms and cottages is dealt with by pail closets and watertight cesspools.

A new gathering ground at Walsden in connection with the intended Ramsden lower reservoir is estimated at 350 acres, between 783 and 1250 feet elevation. Of this, 113 acres, all hill pasture and moor, except 4 acres of plantations, are owned by the Corporation. There are 3 habitations 
upon the area. Mr. Frank H. Brunt, A.M.Inst.C.E., states that the presence of soot is easily discernible on the moorland grass situated within several miles of Rochdale.

Bolton has 12,202 acres of gathering grounds at Entwistle, Belmont, and Heaton. The compensation reservoirs, Belmont, Rumworth, and Wayoh, draw from about half this area; and the Springs, Dingle, Entwistle, High Rid, and Heaton storage reservoirs obtain their domestic water from the other half. Of the total area the Corporation have acquired 7084 acres, of which 6046 acres are in the Belmont area in Turton Urban District, and 915 acres are in the Entwistle area, Darwen Parish. The Corporation have not acquired the gathering grounds of the Heaton and High Rid reservoirs, situated for the most part in the Borough of Bolton, and are unable to exercise effective control over these areas, on which there are 7 farms, 2 public-houses, and 39 cottages, with a population of 216 persons. Notwithstanding the large expenditure by the Corporation in enclosing the streams thereon, and the measures taken to obviate preventable pollution, the water obtained from this source is at times so grossly polluted as to be obnoxious and highly dangerous. The Local Government Board wrote to the Town Clerk on 1st December 1910 as follows: "The Board approve of the exclusion of Heaton water, that has not been subjected to storage, from the supply, and of the decision of the Town Council to abolish in a few years the farms on their gathering grounds. The Board further understand that it is the intention of the Town Council to acquire those parts of the gathering grounds not already in their possession. This is a proposal with which the Board entirely agree."

Mr. Lewis Mitchell, M.Inst.C.E., in charge of the Waterworks, is of opinion that "the storage and filtration of water used for domestic purposes is not sufficient to guarantee its wholesomeness, because the reservoirs become depleted during periods of drought; and subsequently, 
when the rains come, inadequately stored water is drawn for purposes of filtration, and at the same time the filters may not be working efficiently from one cause or another. The degree of safety conferred by storage and filtration is after all a debatable matter. The results of analyses show that not unfrequently the raw waters from the Entwistle, Heaton, and High Rid reservoirs are polluted and unsafe. After heavy rains, when the waters have received the washings from manured fields and slop-water from human dwellings, the organisms present therein have reached several thousands per cubic centimetre, notwithstanding that such waters were stored previous to being drawn for use. The policy of the Corporation in abandoning farms and closing all human habitations on the watersheds supplying domestic water is fully justified."

Some years ago experimental plantations were made on the Belmont watershed by the Corporation; but after the expenditure of large sums of money the venture was not successful, notwithstanding that in the selection of the species and in the mode of planting expert advice had been obtained. In October and December 1912 Mr. Lewis Mitchell wrote two reports on a conjoint scheme of the Liverpool and Bolton Corporations for the afforestation of 6000 acres on the Rivington, Belmont, and Entwistle catchment areas, provided that the assistance of the Development Commissioners could be obtained. The latter sent two experts to examine the watersheds; and after inspecting the growing timber in the district, of which there is very little, they were decidedly of opinion that the scheme of afforestation, if undertaken, would not be successful from a commercial point of view, and the matter was subsequently allowed to drop.

Heywood and Middleton Water Board obtain their water supply from (1) Naden Brook, with a gathering ground of 1250 acres, between 724 and 1500 feet elevation; and (2) Ashworth Moor, gathering ground of 1380 acres, between 926 and 1468 feet elevation. The whole of the 
two areas, totalling 2630 acres, is owned by the Board. Nearly the whole of the ground is hill pasture and moor. The water is filtered. The figures here given were supplied in June 1918 by the Engineer to the Board.

Darwen obtains its water supply from a gathering ground of 660 acres of moorland and hill pasture on Darwen Moors. The water is filtered. No particulars were obtainable from the Town Clerk. The Journal of Board of Agriculture, xi. 469 (1904), states that Darwen owns 500 acres of gathering ground, between 700 and 1300 feet, nearly all hill pasture, with 12 acres of woodland.

Ashton in Makerfield Urban District Council obtain their water supply from a gathering ground of 400 acres at Winstanley. The water is filtered. No other particulars obtainable.

Wigan obtains its water supply in part from two upland surfaces - 2200 acres at Wrightington, between 218 and 400 feet elevation, and 500 acres at Billinge, between 316 and 428 feet elevation. The gathering grounds, which appear to be entirely agricultural land, are not owned by the Corporation. "The farmsteads, etc., are drained and the tanks emptied when required, the contents being carted away and spread over suitable ground to prevent pollution." The whole of these two areas appears to be suitable for afforestation, and, in any case, ought to be under the complete control of the Corporation.

Warrington obtains its domestic supply entirely from wells, but it obtains water for trade purposes from a gathering ground of 1360 acres, between 140 and 250 feet elevation, at Appleton, Hatton, and Daresbury. The Corporation do not own any part of this area, over which they have merely the right to collect the water.

Horwich Urban District Council obtains its water supply from a gathering ground of 97 acres at Wildersmoor, 
between 1146 and 1450 feet elevation, all moorland, with two dwelling-houses and farmsteads upon it. None of the area is owned by the Council. The water is not filtered.

\section{YORKSHIRE}

Twenty-four local authorities and four private companies obtain their water supply from gathering grounds with a total extent of 178,239 acres, of which 33,971 acres are owned by ten corporations. The principal authorities owning water catchment areas in Yorkshire are Leeds, Bradford, Oldham, and Batley. Leeds is the only Corporation which has carried out planting on a large scale. Bradford has always been opposed to any afforestation schemes on its extensive areas. On the Halifax gathering grounds some plantations, made between 1902 and 1909 , have not been successful enough to encourage further effort. Keighley has postponed the consideration of an afforestation scheme till after the war. There are small plantations on the Huddersfield, Oldham, Batley, and Sheffield gathering grounds. In the West Riding of Yorkshire, as in South Lancashire, the deleterious effect of smoke on the growth of trees must be borne in mind when afforestation schemes are under consideration.

Leeds has four catchment areas, with a total extent of 39,474 acres, of which 14,700 acres are owned by the Corporation. For full particulars of these areas and the Washburn Valley afforestation scheme, see pp. 99-101.

Tees Valley Water Board, which supplies Middlesbrough, Stockton-on-Tees, and many villages and towns in Durham, obtains its supply (1) from the Hury and Blackton impounding reservoirs in the valley of the river Balder, Yorkshire, with a catchment area of 10,000 acres, between 860 and 1600 feet elevation ; and (2) from the Grassholme impounding reservoir, in the valley of the river Lune, Yorkshire, with a catchment area of 18,000 acres, between 


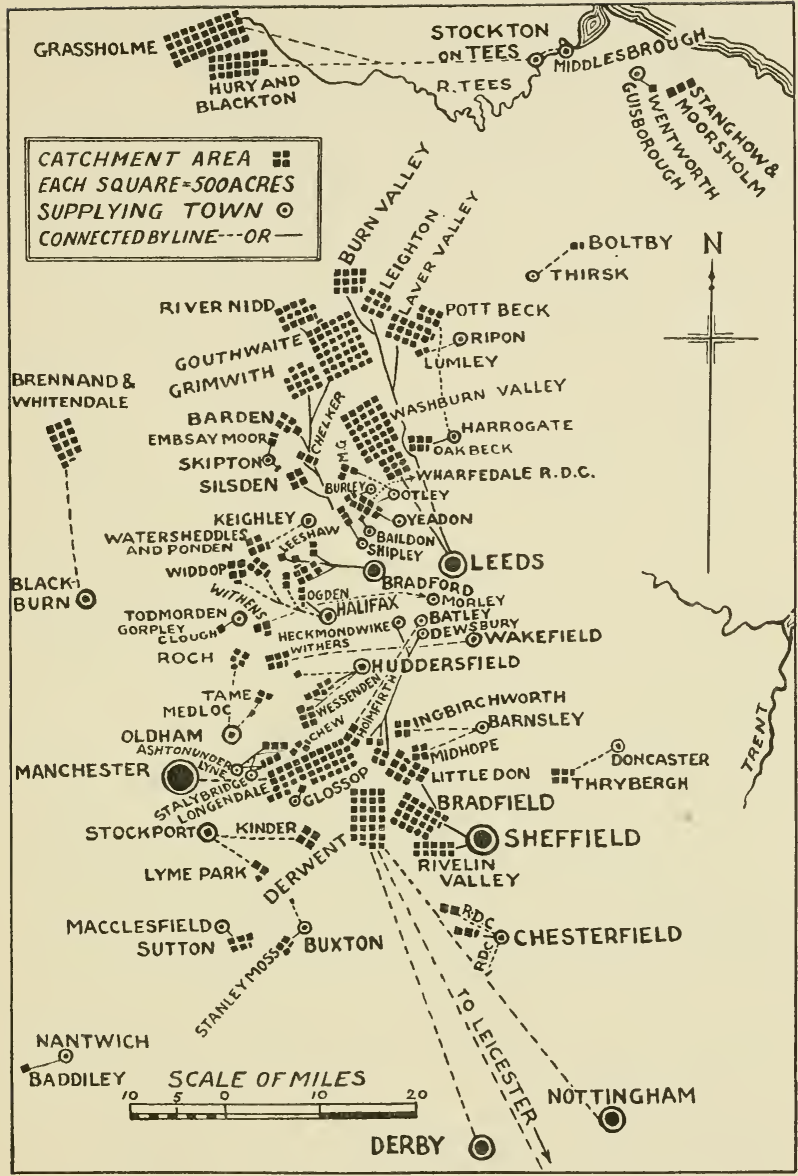

FIG. 36.-Yorkshire, Cheshire, and Derbyshire Catchment Areas. 
903 and 2591 feet, the highest point being Mickle Fell. The Board own 300 acres of the Balder area, and 300 acres of the Lune area, being simply the land on which the reservoirs have been constructed. Fully 95 per cent of both areas is moorland and the remainder hill pasture, there being no arable land and few plantations. There are about 50 or 60 houses and farmsteads on the Balder area, and 70 or 80 houses and farmsteads on the Lune area, wholly tenanted by what are known locally as fell-side sheep farmers. There are no special measures taken on the gathering grounds to prevent contamination, but the water if filtered.

Ripon obtains its water supply from Lumley reservoir, with a gathering ground of 700 acres on Lumley Moor, between 600 and 800 feet elevation, utilising the Holburn, Craven Gill, and South Gill Becks, tributaries of the river Laver. Of the total area, 45 acres are owned by the Corporation, of which about 10 acres are plantations. Ditches are cleaned out, the watershed is carefully looked after, and the water is filtered. I have no information as regards farmsteads and cultivation on the gathering ground, which would seem to be suitable for afforestation.

Harrogate obtains its water supply from two catchment areas : ,

1. A gathering ground of 2720 acres on the head waters of Oak Beck, a tributary of the river Nidd, with four impounding reservoirs, namely, Scargill reservoir, draining 1110 acres; Upper and Lower Beaver Dyke reservoirs, draining 1200 acres; and Ten Acres reservoir, tapping 400 acres. This is moorland and rough pasture at 500 to 800 feet elevation, and with an average annual rainfall of 28 inches.

2. Roundhill reservoir, on Pott Beck, a tributary of the river Burn, has a gathering ground of 3000 acres of moorland, which adjoins the Leighton reservoir area, belonging to Leeds Corporation.

No particulars have been obtained of these two areas, as 
regards either ownership or the precautions taken against contamination. The water is filtered.

Bradford has most extensive waterworks on the Yorkshire moors, with numerous reservoirs and large catchment areas. In the following table, the storage reservoirs for domestic use are in ordinary type, those which give compensation water being in italics.

\begin{tabular}{|c|c|c|c|c|}
\hline Watershed. & & Reservoir. & $\begin{array}{l}\text { Altitude in } \\
\text { feet. }\end{array}$ & $\begin{array}{l}\text { Area in } \\
\text { acres. }\end{array}$ \\
\hline \multirow[t]{4}{*}{ Denholme Beck } & \multirow[t]{4}{*}{. } & Thornton Moor & 1,241 & 1,260 \\
\hline & & Stubden & 1,028 & 900 \\
\hline & & Doe Park & 850 & 1,000 \\
\hline & & Hewenden & 687 & 1,000 \\
\hline \multirow{2}{*}{ River Worth . } & \multirow[t]{2}{*}{. } & Leeming & 836 & 515 \\
\hline & & Leeshaw & 850 & 505 \\
\hline \multirow[t]{4}{*}{ River Wharfe } & \multirow[t]{4}{*}{ - } & Upper Barden & 1,170 & 1,570 \\
\hline & & Lower Barden & 697 & 1,930 \\
\hline & & Chelker & 721 & 1,290 \\
\hline & & Grimwith & 877 & 7,000 \\
\hline \multirow{6}{*}{$\begin{array}{l}\text { River Aire } \\
\text { River Nidd }\end{array}$} & \multirow{6}{*}{. } & Silsden & 580 & 2,000 \\
\hline & & Angram & $1,187)$ & \\
\hline & & Lodge & 1,089 & 6,800 \\
\hline & & High Woodale & 994 & \\
\hline & & (No reservoir)* & ... & 11,400 \\
\hline & & Gouthwaite & 446 & 9,900 \\
\hline
\end{tabular}

* The 11,400 acres just shown in the river Nidd watershed comprise the catchment areas of five small tributary streams, Ruscoe Beck, How Stone Beck, Blayshaw Gill, Ramsgill Beck, and Colt House Beck, the water of which is conveyed directly by pipes into the main aqueduct. In addition to the preceding storage and compensation reservoirs, there are in the vicinity of Bradford the following supply reservoirs without catchment areas: Heaton, 523 feet elevation; Horton Bank, 910 feet; Brayshaw, 975 feet; Idle Hill, 750 feet; and Chellow Heights, 845 feet.

Nearly all the gathering grounds are high moorlands reported to be above the reach of pollution from populated districts. The Corporation owned in 1906, besides small areas (21 acres at Thornton, $113 \frac{1}{2}$ acres at Chellow Heights, $48 \frac{1}{2}$ acres at Gilstead Filter Beds, 43 acres at Morton, 96 acres at Silsden, and $99 \frac{1}{2}$ acres at Grimwith), the following large blocks of land: 
1. In Oxenhope and Denholme Parishes, 1090 acres, acquired at a cost of $£ 44,464$ for the purpose of protecting and preserving the purity of the water drawn from Denholme Moor and Thornton Moor. These lands were let in 1906 , under restrictive clauses as to manuring and tillage, to thirty-six tenants at an average annual rent of $15 \mathrm{~s}$. per acre. Forest timber has not been grown, and no plantations exist on the owned lands or on any other part of these areas, the elevation of which varies from 800 feet at Leeming to 1325 feet at Spring Hall.

2. In Lower Nidderdale, 618 acres, at 460 to 1000 feet elevation, acquired at a cost of $£ 13,850$, and let in 1906 to three tenants at an annual rent of $16 \mathrm{~s}$. per acre.

3. In Upper Nidderdale, 7051 acres, including 109 acres at Lofthouse, acquired at a cost of $£ 2050$ and let as a farm at $£ 50$ yearly. The remaining 6942 acres, acquired for $£ 71,838$, range in elevation from 900 feet at Woodale to 2300 feet on Whernside. This is wild and bleak in winter, and without any trees, being devoted to grazing black-faced hill sheep in summer, and grouse shooting in autumn.

Proposals of afforestation of all these catchment areas were strongly opposed by the engineer, Mr. James Watson, from whose report on 19th January 1906 to the Bradford Waterworks Committee the preceding particulars of ownership are taken. His main contention was that on the higher elevations forest trees would certainly fail to grow, and that at lower altitudes they could scarcely be grown with profit. He raised one objection: the disturbance of the peat by planting operations. The Thornton Moor area, where the peat is abraded and exposed, imparts to the rains an acidity that unless neutralised by constant treatment acts on lead pipes. He considered that the digging of 3000 pits per acre, and the cutting of the necessary drains in the peaty subsoil, would for years render difficult the treatment of the water, and entail serious risk of lead poisoning. He did not believe that tree-planting was work calculated to give more than very short and temporary 
relief to any great number of unemployed. It appears that the Bradford Corporation has spent enormous sums of money on the purchase of the land necessary for its extensive waterworks, and was not inclined to spend any money whatever on afforestation when this was put forward as a means for solving the difficult problem of unemployment in large towns. A pamphlet entitled "Water Supply, with a Description of the Bradford Waterworks," by J. Watson, was published at Bradford in 1900. See also Proc. Assoc. Municipal and County Engineers, xxiv. 128-132 (1898), and Trans. Inst. Water Engineers, xiii. 126 (1908). A good account of the Bradford Waterworks system, with maps, views, and plans, is given in The Engineer, vol. 11.9, pp. 251-254 and 278-280 (March 1915).

Biackburn obtains its water supply from a gathering ground of 6820 acres in Bowland Forest in Yorkshire, comprising the watersheds of the Brennand and Whitendale Streams, tributaries of the river Hodder, at 550 to 1730 feet elevation. The Corporation own 153 acres of the area, which is mostly moorland, without any plantations of note. Mr. W. Stubbs, A.M.I.C.E., in Proc. Inst. Civil Engineers, vol. 194, p. 142, with map (1914), states that the geological formation is Millstone Grit, with outcrops of shale and in places of limestone, retaining the water for long periods. The annual rainfall at six different stations averaged for 1887-1912 from 55.63 to 71.06 inches. The water is not filtered, and no special measures are taken to prevent contamination on the gathering ground. No scheme of afforestation seems to have been proposed. See Fig. 37.

Skipton Urban District Council obtains its water supply from a reservoir on Embsay Moor, with a gathering ground of 700 acres, entirely hill pasture and moorland, free from farms and other sources of contamination. The water is not filtered, but, owing to peaty discoloration, the Council are considering the question of filtration. The reservoir on Rombalds Moor, with 207 acres of gathering ground, of which 7 acres are plantations, is no longer used as a supply 
for domestic purposes. Of the total 907 acres of gathering grounds, only about 5 acres are owned by the Council.

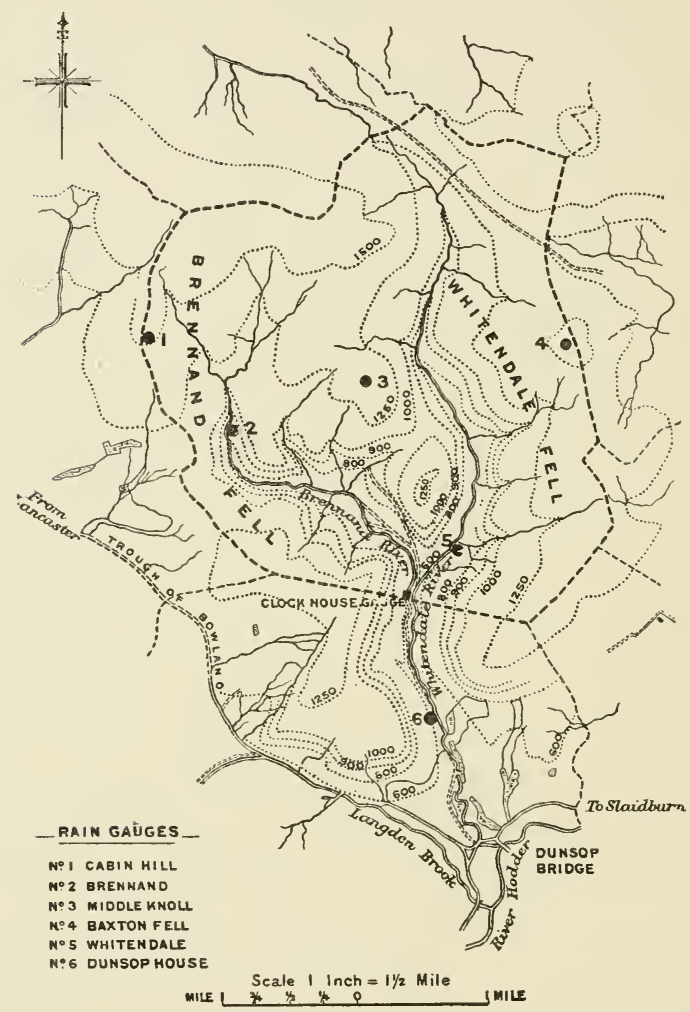

Fig. 37.-Blackburn. Brennand and Whitendale Catchment Area. (From Proc. Inst. Civil Engineers, vol. 194.)

Otley Urban District Council obtains its water supply from March Ghyll, Middleton, with a catchment area of 
1400 acres, between 700 and 1100 feet elevation, all hill pasture and moorland, without any arable land or plantations. The gathering ground, of which about 10 acres are owned by the Council, has no dwelling-houses or farmsteadings upon it. No precautions against contamination of the gathering ground are taken, but the water is filtered. Mr. C. J. F. Atkinson, Clerk to the Council, considers that the area would be an excellent one for an afforestation scheme.

Wharfedale Rural Distrlct Council obtains its water supply from a gathering ground of 2560 acres at Menston, between 900 and 1000 feet elevation, all hill pasture and moorland, without any dwelling-houses or farmsteads upon it. The Council owns only the water rights of the area. The reservoir at Four Lane Ends is at 660 feet elevation.

Shipley Urban Distrlct Council obtains its water supply from a gathering ground of 1537 acres on Rombalds Moor, lying between 690 and 1308 feet elevation, all hill pasture and moor, with the exception of 2 acres of arable land and 7 acres of plantations. There are no habitations or farmsteads on the gathering ground, of which only $11 \frac{1}{2}$ acres are owned by the District Council. Besides filtration and treatment of the water with chalk and carbonate of soda to prevent action on lead, no other measures are considered necessary to preserve the purity of the water. The Graincliffe reservoir at 845 feet elevation serves for domestic supply, and the Eldwick reservoir at 690 feet elevation serves for compensation water.

Burley-in-Wharfedale Urban District Council obtains its water supply from a gathering ground of 800 acres, between 1000 and 1350 feet elevation, all moorland and hill pasture; and owns only 20 acres, the sites of the Carr Bottom, Low Lanshaw, and High Lanshaw reservoirs on Rombalds Moor, and of Hartley's reservoir on the Coldstone Estate. The water from three of the four storage reservoirs is mechanically filtered; the fourth reservoir is not liable to contamination. No other measures are considered necessary to preserve the purity of the water. 
Baildon Urban District Council obtains its" water supply in part from Weecher reservoir, with a gathering ground of 379 acres on Rombalds Moor, all moorland, without any plantations or arable land, and with only one inhabited house upon it. The Council owns none of the gathering ground. The water is not filtered; "and no precautions are considered necessary against contamination."

Keighiey obtains its water supply at present from the Watersheddles reservoir, at the head of the river Worth, at 1100 feet elevation, with a gathering ground of 1600 acres ascending to 1575 feet. Ponden reservoir, at 763 feet elevation, two miles down stream, with a catchment area of 863 acres, provides compensation water to the river. These two contiguous areas are situated on the higher portions of the Oakworth, Stanbury, and Trawden Moors, on the borders of Yorkshire and Lancashire; and consist mainly of moorland over Millstone Grit, without any plantations and with only 143 acres of arable land. The Corporation have acquired the freehold of 2577 acres, and have also obtained powers to make bye-laws for the prevention of nuisances and pollution on the areas, which are without any population or habitations; but no special bye-laws have been as yet drawn up. The annual rainfall at Watersheddles reservoir varies between 39.81 and 68.19 inches, averaging 50.30 inches for 19 years. The water is slightly brownish in colour and has an acid reaction, owing to the peat; and to obviate its action on lead, it is passed through filters at Oldfield.

At present new waterworks are being carried out by the Keighley Corporation in the Sladen Valley, where a reservoir called Lower Laithe is being formed by the construction of an earthen embankment across Sladen Beck, in Haworth and Stanbury parishes. The catchment area, 1080 acres, of which 1000 acres are owned by the Corporation, lies between 741 feet, the level of the reservoir, and 1450 feet elevation. There are no plantations on any of the catchment areas; but a scheme of afforestation was under consideration 
when the war began, which is held over until more favoulable circumstances return.

The Annual Report of the Keighley Waterworks, by M. Ratcliffe Barnett, M.Inst.C.E., published in August 1915 , gives a complete account of the various undertakings and is accompanied by a map.

Halifax has four moorland gathering grounds, with a total area of 7322 acres, as follows:

1. In the Hebble Valley, Ogden reservoir, at 990 feet elevation, serving for compensation and domestic supply, has a catchment area of 1140 acres. Mixenden reservoir, 875 feet elevation, domestic and general supply, has a catchment area of 190 acres.

2. In the Luddenden Valley, Fly or Warley reservoir, 1350 feet elevation, compensation, has a catchment area of 919 acres. Lower and Upper Dean Head reservoirs, 975 and 1000 feet elevation, domestic and general supply, have a catchment area of 525 acres.

3. Widdop reservoir, at 1050 feet elevation, on a stream of the same name, also receives by a tunnel the water of the Greave Valley, and serving for compensation and general supply, has a catchment area of 2223 acres.

4. Lower Walshaw Dean reservoir, 965 feet elevation, for compensation, and Middle and Upper Walshaw Dean reservoirs, 1043 and 1100 feet elevation, for general supply, have a united catchment area of 2325 acres.

The whole of the gathering grounds, the lowest point of which is 875 feet elevation, are either moorland or mountain grazing over Millstone Grit. The Corporation own only a part of the area, viz. 1310 acres, all in the Hebble Valley. The eminent botanists, Mr. W. Crump and Dr. W. G. Smith, who have done so much excellent work in plant ecology and in producing vegetation maps of Yorkshire, etc., strongly urged in 1902 the afforestation of these gathering grounds. In that year 38 acres at Ogden and 12 acres at Mixenden were planted, to which 37 acres were added in February 1909. Success was 
anticipated, as both Ogden and Mixenden reservoirs, though situated at nearly 1000 feet elevation, lie in well-sheltered valleys. I have not been able to obtain any report on these plantations, as, for some reason or another, little interest has been taken in afforestation by the Halifax Corporation. No forester is employed. See Trans. Roy. Scot. Arbor. Soc. xvii. pp. 86-92 (1904), for reports on the afforestation of the Halifax areas.

Todmorden obtains its water supply from Gorpley Clough reservoir, with a gathering ground on Inchfield Moor of 690 acres, between 845 and 1500 feet elevation. The whole area, of which about 600 acres are owned by the Corporation, is hill pasture and moor, without any plantations or arable land, and free from farmsteads or habitations, except the waterman's house. The water is filtered, and no other precautions are considered necessary. See Trans. Liverpool Engineering Soc. xxix. (1908).

Morley obtains its water supply in part from Withens reservoir in Cragg Vale, Mytholmroyd, with a gathering ground of 1200 acres, between 900 and 1000 feet elevation, all hill pasture and moorland; and no part of it is owned by the Corporation. The area is without habitations or farmsteads, except a gamekeeper's lodge, uninhabited at present. The water is filtered, and no other precautions are considered necessary.

Wakefield obtains its water supply from a gathering ground of 2737 acres, between 1000 and 1530 feet elevation, with two reservoirs, Green Withers at Rishworth, and Ringstone at Barkisland. The Ardsley reservoir, also used for storage, is not on the catchment area. The Corporation have power to utilise a further area of 600 acres, all moorland and lying between 900 and 1200 feet, and to construct thereon three additional (Oxygrains, Upper and Lower Booth Dean) reservoirs. The gathering ground of 2737 acres to the existing works, is all moorland, with the exception of about 250 acres of rough grass; and most of it is covered with peat varying in depth from one 
foot to eight or ten feet, overlying the grits and slates of the Millstone Grit, with occasional patches of clay. The chief vegetation is rough moorland grass and bilberry, with very little heather. The peat contains remains of roots and stems of birch trees, but there are probably now not half-adozen trees on the whole ground. The catchment area being within easy reach of manufacturing districts, any trees that might be planted would have to grow in an atmosphere nearly always smoke-laden. The Corporation do not own and have no control over the area, on which there is only one habitation, a gamekeeper's house, the drainage of which is piped clear of the gathering ground. As no farming operations are carried on, no measure, other than filtration, is needed to render the water safe. See Trans. Inst. Water Engineer's, xviii. (1913).

Huddersfield obtains its water supply from four gathering grounds :

Blackmoorfoot reservoir, catchment area of 1871 acres, between 830 and 1100 feet elevation.

Deer Hill reservoir, catchment area of 1000 acres, between 1140 and 1400 feet elevation.

Wessenden, Wessenden Head, Blakeley, and Butterley reservoirs, eatchment area of 2825 acres, between 770 and 1500 feet elevation.

Dean Head reservoir, catchment area of 500 acres, between 1000 and 1200 feet elevation.

The gathering grounds aggregate 6196 acres, which comprise 5993 acres of moorland and hill pasture, 150 acres of arable land, and 53 acres of plantations. The Corporation own 1200 acres, and the plantations are upon the land owned by them. There are a few scattered farmsteads on the watersheds, the sewage from which discharges into cesspools that are cleared out periodically. All the water except that from springs is filtered. See maps of vegetation and description of Huddersfield district by T. W. Woodhead, in Journ. Linnean Soc. (Botany), vol. xxxvii. $333-406$ (1905). 
Oldham has a moorland gathering ground of 5480 acres in the Pennine Range, Yorkshire, of which 3027 acres are owned by the Corporation. There are three catchment areas as follows: River Medlock area, 660 acres in extent, between 778 and 1225 feet elevation; River Roach area, 2520 acres in extent, between 690 and 1500 feet elevation; River Tame area, 2300 acres in extent, between 762 and 1500 feet elevation. The Corporation own 199 acres on the Medlock area, 1196 acres on the Roach area, and 1632 acres on the Tame area.

Only 40 acres have been planted with trees, viz. 1.6 acres each on the Roach and Tame areas, and 8 acres on the Medlock area. The water is not filtered. The Corporation have been enabled by their purchase of land to demolish all the habitations on the gathering ground. On the lands draining to the domestic supply reservoirs, only sheep grazing is allowed and no cultivation or manuring is permitted.

Batley has a gathering ground of 1600 acres at Holmfirth, on the north-east slope of the Pennine range, between 770 and 1720 feet elevation, all hill pasture with underlying peat, except 20 acres of arable land annually under the plough, and 25 acres of very poor plantations. The Corporation recently purchased 600 acres of the area, all below 1500 feet altitude. There are 10 habitations (some empty) and 8 farm-steadings (some unused); but the water for domestic use, which is not filtered, is drawn from the reservoir above the level of the habitations and cultivated lands. Farms and buildings are carefully drained, and tillage is controlled as much as possible, most of the land being used for grazing. There are three storage reservoirs, Yateholme, Riding Hood, and Ramsden, all together on the Ramsden Clough Stream at the head-waters of the river Holme, 2 to 3 miles south-west of Holmfirth, and $\frac{1}{2}$ mile south-east of Holme. The annual rainfall for 20 years ranged between 40.1 and 73.3 inches, averaging 59 inches. 
Dewsbury and Heckmondwike Waterworks Board obtain their water supply from four catchment areas as follows:

Dunford Bridge Reservoir 1300 acres between 1100 and 1489 feet elevation. Upper and Lower Windle-

den Reservoirs . - 702 ", ", 1150 ,, 1500 ,, ", Harden Reservoir . . 277 " ", 1201 ", 1560 ", ", Snailsden Reservoir . 209 ", " 1369 ", 1560 ", ",

Of the whole area, 2488 acres, the Board own only the sites of the reservoirs, embankments, and other structural works. The area is entirely moorland, without any cultivation, and no measures are considered necessary against contamination of the water, which is not filtered. "The bacteriological examinations and reports are always satisfactory."

Barnsley has two catchment areas, viz. Ingbirchworth reservoir, 2000 acres, between 800 and 1400 feet elevation, and Midhope reservoir, 2000 acres, between 800 and 1600 feet elevation. The latter area is adjacent to the Langsett area of Sheffield. Both gathering grounds, which are held by private owners, are nearly all pasture or moorland, the amount of arable land being very small. The Council, in the spring of 1917, planted out 25,000 Scots pines and 5000 larches. The water is filtered.

Sheffeld obtains its water supply in part from the adjacent moorlands on the west, which comprise three watersheds as follows :

Rivelin Valley : 4978 acres at 700 to 1300 feet altitude, with 5 reservoirs, Upper, Lower, and Middle Redmires reservoirs, at 1150,1105 , and 1068 feet, and Upper and Lower Rivelin reservoirs at 698 and 672 feet elevation.

Loxley Valley or Bradfield area: 10,725 acres at 650 to 1326 feet altitude, with Agden (643 feet), Strines (814 feet), Dale Dike (696 feet), and Damflask (505 feet) reservoirs.

Little Don Valley: 5203 acres at 1037 to 1516 feet elevation, with Langsett reservoir at 810 feet altitude. In 
the same valley there is a compensation reservoir at Underbank at 600 feet elevation and draining 3000 acres.

The gathering grounds, 23,906 acres in all, are not owned by the Corporation, and consist for the most part of moorland, with a very small population. No large scheme for afforestation has been proposed. Owing to non-ownership, the question has not been taken up by the Corporation, who have planted small areas immediately adjacent to the reservoirs on suitable soil with Scots pine, larch, and birch. The engineer, Mr. L. S. M. Marsh, doubts whether advantage would be derived by planting exposed moorland. See notes on the Sheffield water supply in Proc. Inst. Civil Engineers, vol. 181, pp. 1-14 (1910).

The Sheffield Corporation decided in 1913 to proceed with the construction of two new reservoirs, Broomhead and More Hall reservoirs, with a catchment area of 6496 acres in the Ewden Valley, which is a short arm of the Little Don Valley. The gathering ground includes the well-known Broomhead moor, and the valley itself is one of the most beautiful in Yorkshire. The new project is described, with sketch map of the four catchment areas and views of Ewden Valley, in The Engineer, 14th Nov. 1913, pp. 510 and 520.

Sheffield obtains an independent water supply from the Derwent Valley Water Board.

Doncaster obtains its water supply in part from an impounding reservoir at Thrybergh, with 2517 acres of gathering ground on the hills south-west of Conisborough, all pasture and arable land at the low elevation of 180 to 450 feet. Most of the area does not belong to the Corporation, who merely exercise sanitary control over it. I am informed officially, that "As the character of the land was entirely rural at the time the impounding reservoir was constructed, no farms or houses were removed; and there are certainly not more than 40 habitations on the whole of the area at the present moment. It has only been found necessary to exercise supervision over the manuring of the arable land, and the removal of carcases from the neigh- 
bourhood of the water courses, to guard against pollution. Practically no difficulty has arisen since the establishment of the Thrybergh reservoir, from the point of view of pollution; and any small difficulty which may arise from time to time has up till now been settled mutually."

Guisborough Water Company obtain their supply from the Wentworth Plantation reservoir, with a gathering ground of 550 acres, between 500 and 750 feet elevation. The area, which is all moorland, except 50 acres of plantations, is without habitations or farmsteads. The water is filtered, and no other measures are taken against contamination.

Yeadon Waterworks Company obtain their supply from Reva reservoir, with a gathering ground of 720 acres on Hawksworth Moor, between 750 and 800 feet elevation, all hill pasture and moorland and without plantations. The Company have water rights over the area, of which they own only 30 acres. There is one farmstead and two cottages on the gathering ground. The water is filtered.

Thirsk District Water Company, Ltd., obtain their water supply from a gathering ground at Boltby, 800 acres in extent, between 650 and 1200 feet elevation. The whole area is covered with heather and bracken, and is without habitations or plantations, none of it being owned by the Company. There is nothing to contaminate the water, which is strained but not filtered.

Cleveland Water Company obtain their water supply in part from a gathering ground of 1150 acres in Stanghow and Moorsholm, between 650 and 920 feet elevation. The Company have no rights over the area, except a perpetual easement over 42 acres covered by the Lockwood Moorland reservoir and filter beds. The gathering ground is all moorland without habitations or plantations, and there is no chance of contamination of the water. 


\section{Cheshire and Derbyshire}

Ten local authorities obtain their water supply from gathering grounds with a total extent of 48,743 acres, of which 10,522 acres are owned by six Corporations. The chief authorities owning water catchment areas in Cheshire and Derbyshire are Manchester, Ashton-under-Lyne, Stockport,

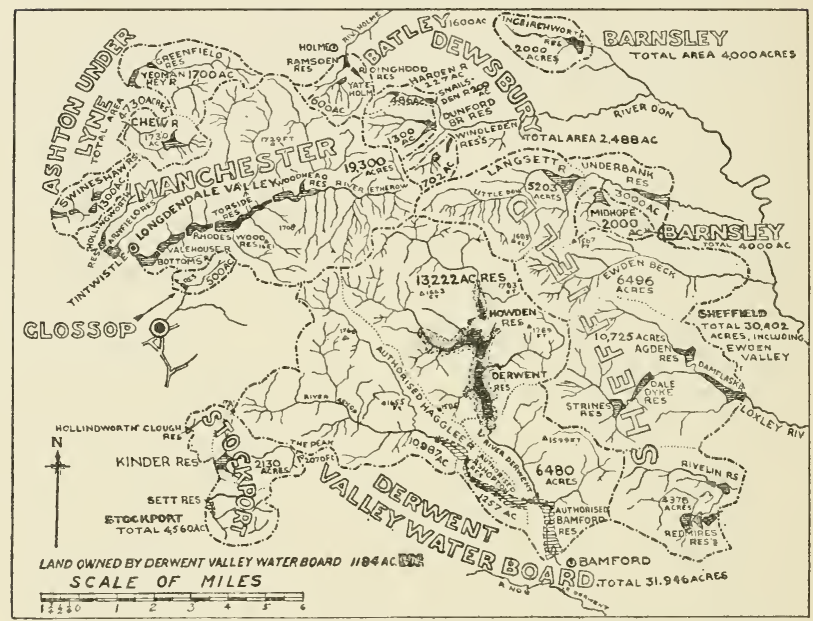

FIG. 38.-Longdendale, Derwent Valley, and neighbouring Catchment Areas.

and Derwent Valley Water Board. Small plantations exist on several of the areas, but no large scheme of afforestation has been proposed by any of the authorities. Dr. C. E. Moss gives in his book, Vegetation of the Peak District (1912), two maps, on which the position of the reservoirs, the distribution of the vegetation, etc., of most of these catchment areas are well shown.

Longdendale catchment area, 19,300 acres, supplying 
Manchester; about 6400 acres are owned by the Manchester Corporation. See full description, p. 98.

\section{Ashton-under-Lyne, Stalybridge, and Dukinfleld (District)} Waterworks Joint Committee obtain their supply from three catchment areas :

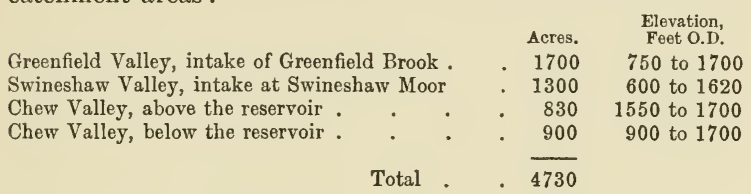

The storage reservoirs with their elevations above sealevel are: Brushes, 649 feet; Lower Swineshaw, 871 feet; Higher Swineshaw, 957 feet; Yeoman Hey, 768 feet; and Greenfield, 892 feet. There are also two compensation reservoirs-Walker Wood, 588 feet, and Chew, 1600 feet.

The Joint Committee have purchased and own 2500 acres, namely, 1310 acres in Greenfield area, 70 acres in Swineshaw area, and 1120 acres in Chew area. There is one holding on Greenfield area, one holding on Swineshaw area, and two holdings on that part of Chew area which is not used for domestic supply; but there are restrictions as to manures, and animals kept on the farms, besides close inspection. The water is filtered. There are the remains of what were formerly plantations, but which now consist of a few straggling trees only. This appears to be due to atmospheric change, as there is evidence that in days gone by trees were very prevalent and flourishing on the gathering ground. The engineer, Mr. G. R. Raddin, B.E., says it is more satisfactory to have ownership control of the area, as there is less trespassing, better regulation of indiscriminate rambling, with restrictions as to manuring land and grazing of eattle, and with power to clear land of farms.

Stockport obtains its water supply from two catchment areas-Lyme Park area, 1400 acres, between 650 feet and 
1300 feet elevation, with two storage reservoirs, Bollinhurst and Horse Coppice; and Kinder (Hayfield) area, 2130 acres, between 916 and 2080 feet elevation, with Kinder reservoir, two miles distant from Hayfield, and at the base of Kinder Scout, the highest point on the area. The Lyme Park area consists of 540 acres of moor, 652 acres of arable land and pasture, 180 acres of woodland, and 28 acres of water. The Kinder area consists of 1882 acres of moor, 180 acres of arable and pasture, 25 acres of woodland, and 43 acres of water. The Corporation own 44 acres of the Lyme Park area and 220 acres of the Kinder area. The water is filtered, and "all farmsteads are drained, and the drainage used to irrigate the land by special means." On the Kinder area, arrangements have been made with the owners that no cultivation shall take place and no cattle shall be allowed. There is only one dwelling, the drainage from which, after treatment, is delivered to the stream below the reservoir embankment. The average annual rainfall on the Kinder area is 42 inches, and on the Lyme Park gathering ground 33 inches.

The two watersheds on the Sett and Hollingworth Clough, some 2430 acres in extent, adjoining the Kinder area, are included in the completed scheme of supply, but it is not anticipated that further works will be required for many years. The upper part of these areas is covered with peat, varying in depth from a few inches to several feet, and is destitute of population and free from pollution.

An account of the Stockport water supply with map is given by Mr. T. Molyneux, A.M.Inst.C.E., in Trans. Inst. Water Engineers, xix. No. 3 (1914). See also The Engineer, 12 th July 1912, p. 29.

Macclesfield obtains its water supply from upland gathering grounds in Sutton and Macclesfield Forest, in connection with four storage reservoirs, as follows:

Ridgegate Reservoir

Bottoms Reservoir.

Tegsnose Wood Reservoir

Leadbetters Reservoir

\begin{tabular}{|c|c|c|c|c|c|}
\hline 420 & ", & 680, & 1530 & ", & , \\
\hline 450 & , & 690 , & 1250 & ", & , \\
\hline 350 & ", & 620 , & 1200 & , & , \\
\hline
\end{tabular}


thus making a total of 2200 acres of catchment area, which consists of 1900 acres of hill pasture and moorland and 300 acres of woodland and plantations. The Corporation only own 90 acres, but have all water rights over 1750 acres, and part rights over 450 acres. There are four habitations and 18 farm-steadings on the area. The water is filtered. The Macclesfield Forest has been fully described by Miss Lilian Baker in Geographical Journal, xlvi. 213, 289 (1915):

"Popularly described as moorland, it is really grassland, of the siliceous type, the drier parts having Nardus stricta dominant, with Agrostis alba and canina, Luzula campestris, and various species of Carex. The grey colour of the Nardus during autumn, winter, and early spring adds largely to the bleak aspect of the district. The wetter parts, with Molinia coerulea dominant, have also heather, Erica cinerea and tetralix, Scirpus caespitosus, and various species of Juncus. The upland farms are now largely given up to sheep and cattle rearing, but the nearness of industrial centres, the excellence of the roads, and the industry of the farmers are shown in the height to which cultivation has been pushed. Oats occur up to 1000 feet, and wheat ascends to 500 feet. Owing to the effect of wind, trees are now confined to sheltered valleys. Birch occurs on steep slopes high up. Scots pine has been extensively planted, and been very successful. Afforesting would need so much capital that the farmer prefers the smaller profits and quicker returns of sheep farming."

Glossop obtains its water supply from Swinshaw reservoir, $1 \frac{1}{2}$ miles north of the town, and situated on the Blackshaw Clough stream, with a catchment area of 500 acres on Blake Moor, between 733 and 1200 feet elevation. The gathering ground is entirely hill pasture and moorland, without any habitations or farmsteads, and is free from contamination. None of the area is owned by the Corporation. "The water, before reaching the reservoir, passes through a settling tank; flood water is turned to waste. The water, which is not filtered, is found pure on analysis." 
Buxton Urban District Council obtains its water supply in part from two gathering grounds-Coombs Moss area, 200 acres, between 1300 and 1400 feet elevation, with two reservoirs at Lightwood; and Stanley Moss area, 1700 acres, between 1450 and 1550 feet elevation, with one reservoir. These areas, which are not owned by the Council, are entirely moorland, without habitations, farmsteads, or plantations. The water is passed through highpressure filters.

The Derwent Valley Water Board supply water to Derby, Leicester, Nottingham, and Sheffield from a catchment area of 13,220 acres at the head-waters of the river Derwent in High Peak, Derbyshire and Yorkshire. It is mostly rough pasture and heather-covered grouse moors, with steep hill slopes, the elevation ranging from 700 to 1793 feet. The Board own 1184 acres, fringing the two reservoirs, Howden reservoir (870 feet altitude) and Derwent reservoir ( 776 feet altitude). There were a few farm-houses on this part of the area which was mostly rough grazing, but there now remain only three dwelling-houses, one unoccupied and two inhabited by the Board's workmen. The sewage from all three houses soaks through the land before it reaches the reservoir. The Board have no rights over the privately owned portion of the catchment area, but they have power to agree as to the drainage of the lands for more effectually collecting, conveying, and preserving the purity of the waters flowing on such lands into the reservoirs.

The Board have planted up to February 1918, within the boundary of their land, 310 acres of plantations at elevations between 700 and 1500 feet. There are a few plantations outside the Board's lands. The annual rainfall of 59 stations for 13 years varied from 34 to 61 inches. All the water, except that supplied to Sheffield, is passed through sand filters at Bamford.

The works authorised by Act of Parliament of 1899, of which only the Howden and Derwent reservoirs have been 
completed, comprised in all six reservoirs (one of which, the highest and smallest, has been abandoned), with a total gathering ground of 31,946 acres, at an elevation varying from 500 to 2000 feet. Full particulars of the entire scheme were given by Mr. E. Sandeman, M.Inst.C.E., in Proc. Inst. C.E. vol. 194, pp. 22-35, with map (1914); in Trans. Inst. Water Engineers, xvi. pp. 71-75, with map (1912); and in a paper read at the Institution of Civil Engineers on 9 th April 1918. The watershed is described by H. H. Arnold-Bemrose, Derbyshire, p. 21 (1910).

Chesterfield Gas and Water Board obtain part of their water supply from a gathering ground at Linacre, with three storage reservoirs, 1333 acres in extent, between 470 and 1000 feet elevation. The area, of which the Board only own 84 acres, comprises 50 acres of arable land, 1027 acres of hill pasture and moor, and 172 acres of plantations. There are habitations and farm-steadings upon the area, and no special precautions are taken to prevent contamination of the gathering ground. The water is filtered.

Chesterfield Rural District Council obtains its water supply from two catchment areas:

Press gathering ground, 500 acres, between 700 and 1000 feet elevation; all arable land, with a few dwellinghouses and farmsteads upon it.

Barbrook gathering ground, 1030 acres, between 1000 and 1200 feet elevation ; all hill pasture and moor, without any habitations or farmsteads.

The Council owns no part of either area. No special measures are taken against contamination. The water of the Press area is filtered.

Nantwich Urban District Council obtains its water supply from a gathering ground of 500 acres at Baddiley, consisting of agricultural land at a low elevation. The Council owns only two acres, which are willow beds and bog. The water, although filtered, is reported to be bacteriologically 
polluted and unsafe. No measures have been taken or are contemplated to acquire ownership. Steps were taken to obtain a new supply from springs at Madeley (Salop), but the project has been postponed on account of the war.

\section{Northamptonshire, Leicestershire, AND LincolnshiRe}

Six local authorities and one private company obtain their water supply from gathering grounds with a total extent of 24,774 acres, of which 698 acres are owned by three Corporations.

These Midland catchment areas, some of which supply large centres of population, are not situated in high moorland districts, but on the contrary consist of agricultural land with dwelling-houses and farm-steadings. Whether the bye-laws and other precautions taken against contamination are adequate is a matter of opinion. The main arguments for the present system are that farms are very expensive to purchase, and that afforestation, after the abandonment of agriculture and removal of the farmhouses, would be costly at the start, with only remote prospects of financial returns in the distant future. Kettering affords a good example of the difficulties with which local authorities have to contend. Attention may also be paid to low-lying catchment areas in other districts, as those of Doncaster, Nantwich, Exmouth, etc.

Northampton obtains its water supply in part from Teeton Brook, with a storage reservoir near Ravensthorpe, with a gathering ground of 3000 acres, between 353 and 630 feet elevation, consisting mainly of arable land and pasture, and with 49 dwelling-houses upon it. The Corporation own 500 acres of the area, and "treat the sewage of properties within the gathering ground so as to prevent direct connection of offensive matter with the streams flowing into the reservoir." The water is filtered. 


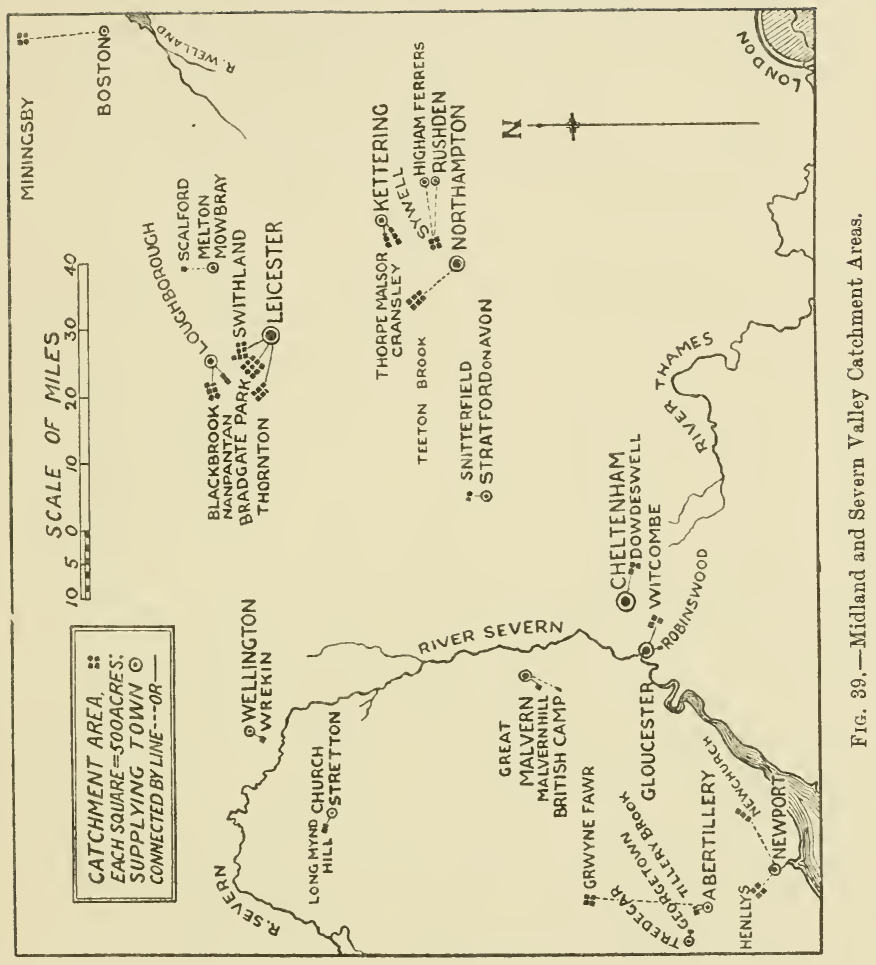


Higham Ferrers and Rushden Water Board obtain their water supply in part from an upland gathering ground of 1747 acres at Sywell, between 260 and 400 feet elevation. The Board own only 65 acres immediately adjoining the Sywell storage reservoir. The gathering ground, of which I have not been able to obtain any definite particulars, appears to consist of arable land and pasture, with habitations and farmsteads upon it. Besides filtration, no special measures are taken to prevent contamination of the gathering ground.

Kettering has two catchment areas: (1) Cransley, about 1800 acres, and (2) Thorpe Malsor, 1330 acres. The Urban District Council have been able to purchase only the actual sites of the two reservoirs and a small margin round them, the land now owned at the Cransley waterworks being 73 acres, and at the Thorpe Malsor reservoir 60 acres. Mr. T. Reader Smith, the engineer in charge, in his interesting report in Journ. Sanitary Instit. xxii. 479 of 1901, explained that the catchment areas, being agricultural land with numerous farmsteadings and other buildings, were much too expensive to purchase. In order to keep the area in a proper sanitary condition, the Council obtained powers, in the Kettering Urban District Water Act, 1901, Section 30, to make bye-laws for this purpose. Under clause 4 of this section, the Council are liable to pay compensation to owners and other persons interested, who may be injuriously affected by any restrictions imposed by such bye-laws. The Council instituted enquiries and ascertained that other water authorities, with similar powers in their water acts, had refrained from making bye-laws because of the expense to which they might be put on account of the various compensations that might be demanded. The Kettering Council is still in the position that while it has power to make bye-laws, none have as yet been made. Meanwhile, the Council merely keep an oversight over the catchment areas, making inspections from 
time to time to see that reasonable sanitary conditions are maintained; and for so far this is said to have worked satisfactorily. The water collected from the catchment areas is filtered, and undergoes a chemical examination quarterly. Nevertheless, the conditions are not ideal, as may be inferred from the following account supplied me by Mr. T. Reader Smith.

The catchment areas are geologically Northampton sands, which contain a great deal of ironstone, worked by open quarrying. In 1917, the Cransley area contained approximately 790 acres of arable land, 830 acres of grazing land, and 88 acres of woods, and the Thorpe Malsor area contained approximately 620 acres of arable land, 630 acres of grazing land, and 34 acres of woods. On the Cransley area there are numerous habitations, including 7 large houses, a corn-mill, 16 cottages, and 3 separate cowsheds and yards; and besides, allotinent ground and ironstone workings. On the Thorpe Malsor catchment area there are 4 large houses, a public-house, 8 cottages, and an isolated cowshed, besides some iron workings. I have no information how the sewage from the human habitations, cow-houses, etc., is diverted from the water that eventually finds its way into the reservoirs.

Loughborough obtains its water supply from two areas in the Charnwood Forest district, with a total extent of 3917 acres. Nanpantan reservoir, on the Woodbrook stream, has a gathering ground of 1050 acres, with 9 habitations and farmsteads upon it. Blackbrook reservoir, on the Blackbrook stream, near Shepshed, has a gathering ground of 2867 acres, with 32 habitations and farmsteads upon it. The Corporation own no part of the two areas, but "all farms and occupied premises are inspected periodically to ensure that the sewage and other sources of pollution are properly dealt with, and the water courses not contaminated." The water is filtered. I have not been furnished with any description of the gathering grounds, which as regards afforestation are probably similar in their 
conditions to the adjoining catchment areas of the Leicester Corporation.

Leicester obtains its water supply in part from three gathering grounds, each with a storage reservoir, in the Charnwood Forest district: (1) Thornton, 2860 acres; (2) Bradgate Park, 4400 acres; and (3) Swithland, 3500 acres; in all, 10,760 acres, over red marl and clay. The average elevation is 400 feet, the highest point in the district being Bardon Hill, 902 feet above sea-level. The land consists of small woods, poor pasture, arable land, and rocks; and the Council only own the sites of the reservoirs and a small margin around them. About two hundred years ago, the timber in this district, mostly oak, was all cleared, and the land remained bare till the Enclosure of 1812, when the high price of corn encouraged tillage. Numerous small woods, mostly oak and larch, were planted later. The rocks are Cambrian syenite, slate and trap, very hard but overlaid in the valleys with boulder clay and other glacial detritus. Mr. L. Fosbrooke of Ravenstone Hall, Leicester, who is well acquainted with the neighbourhood, is of opinion that these gathering grounds would be suitable for the creation of a coniferous forest, exceeding 10,000 acres in extent. Such a forest would prove remunerative within a short term of years on account of the demand for pitwood by the collieries on the western boundary of the district. Sir J. Rolleston, however, at the Board of Agriculture Conference on Afforestation, in 1907, gave his opinion as follows: "Those Corporations like Liverpool, which have bought their watersheds and have large tracts of land of no value for pasture or agriculture, can produce these schemes; but other towns which have not the land would not be able to do so. For instance, a town like Leicester, situated in the midst of the best grazing districts of the country, would hardly be likely to find lands suitable for any extensive scheme of afforestation."

Melton Mowbray Urban District Council obtains its water supply from a gathering ground of 300 acres at Scalford, 
between 390 and 421 feet elevation. The Council owns none of the land, but pays way-leaves for part of the gathering drains as permanent compensation, and pays rental for the rest. These gathering drains are not satisfactory in the absence of a reservoir and filters, as the supply is very intermittent, and at times would be quite insufficient, except for a temporary supply obtained by pumping from springs at Scalford. No other measures have been taken by the Council, who, however, contemplated a new scheme just before the war broke out.

Boston Waterworks Company obtain their water supply from Miningsby Beck and Claxby Beck, with a gathering ground of 1920 acres, between 130 and 330 feet elevation, none of which is owned by the Company. The area comprises 1020 acres of hill pasture and moor, 100 acres of plantations, and 800 acres of arable land, with three small farmsteads and about thirty houses. "Drainage from farms and buildings is carried into septic tanks and discharged over grass land before getting into the natural stream. Every house on the watershed is periodically visited, and any defects in the disposal of slopwater are noted and remedied." The water is filtered. The Manager of the Waterworks, Mr. John Shaw, says that the 80 acres of plantations around the reservoirs at Revesby and Claxby Pluckacre are not an unmixed blessing, as the fall of the leaves perceptibly increases the albuminoid ammonia in autumn, when the prevailing wind blows large quantities of dead leaves into the water. He believes, however, that the trees attract moisture and prevent evaporation, as compared with cultivated land on their watershed.

Scunthorpe Urban District Council is reported in Parliamentary "Return as to Water Undertakings in England and Wales," 1915 , p. 126 , to obtain its water supply from an upland gathering ground over limestone of 1200 acres. The water is, however, an underground supply which is tapped by three borings at Roxby, Scunthorpe, and Rough 
Bottom Plantation. There is no filtration. See W. A. E. Ussher, "Report on Geology of Risby Warren," printed at Scunthorpe in 1912. This gathering ground is not included in the total 24,774 acres, of p. 212 .

\section{Severn Basin, Devon, and Cornwall}

Twenty local authorities and two private companies obtain their water supply from gathering grounds aggregating 34,103 acres, of which 10,862 acres are owned by nine Corporations. The most important areas owned by local authorities are those of Plymouth, Torquay, Paignton, and Stratford-on-Avon. A good deal of planting is being regularly carried out by the Torquay Corporation on their area. Plymouth is contemplating a scheme of afforestation after the war. There are considerable plantations on the Taunton, Exmouth, Penzance, and Wellington (Salop) areas. The Plymouth water eatchment area has an interesting history, and is exceptional in the amount of water which it stores up.

Church Stretton Urban District Council obtains its water supply from a gathering ground of 700 acres, between 900 and 1550 feet elevation, on the Long Mynd Hill in Shropshire. The area, of which none is owned by the Council, is all hill pasture and moor, without habitations, farmsteads, or plantations. The water is not filtered, and no special measures are taken on the gathering ground against contamination.

Wellington (Salop) Urban District Councll obtains part of its water supply from the Wrekin and Buckatree streams, with a catchment area of 500 acres, between 500 and 1284 feet elevation. The gathering ground, none of which is owned by the Council, comprises 170 acres of hill pasture and moor, and 330 acres of plantations, and has one small farmstead and a refreshment house upon it. The water is filtered, and sterilised by means of chlorine. 
Malvern Urban District Council obtains its water supply in part from two gathering grounds :

(1) Malvern Hill, north of Wyche Cutting, with three small covered reservoirs, 300 acres, between 650 and 1300 feet elevation; and (2) British Camp reservoir, with a gathering ground of 177 acres, between 650 and 1000 feet elevation.

The areas, none of which are owned by the Council, are all hill pasture, without habitations. The water is filtered.

Full particulars of the Malvern water supply were given by Mr. W. Osborne Thorp in Proc. Inst. Municipal and County Engineers, vol. 35, p. 238 (1909).

Stratford-upon-Avon obtains its supply from the Snitterfield reservoir, 3 miles distant, and at 296 feet altitude, to which the water is conveyed by a conduit, $\frac{3}{4}$ mile long, from the Snitterfield brook. The water is filtered. The Town Council purchased the Wayfield estate of 430 acres in 1893 for $£ 7546$, and the Comyns Park estate of 292 acres in 1897 for $£ 5440$, making a total of 722 acres, upon which the gathering ground of 490 acres is situated. This consisted in 1918 of 58 acres of arable land, 422 acres of pasture, and 10 acres of woodland. Its highest point is 366 feet above sea-level, and the average annual rainfall is 27 inches. "The ownership of the gathering ground gives the Corporation full control over the method of cultivation and manuring, and affords the greatest security that can be looked for against contamination."

Cheltenham obtains its water supply in part from the Dowdeswell reservoir, on the river Chelt, with a catchment area of 1430 acres in the Cotswold Hills, on which there are habitations and farmsteads. None of the area belongs to the Corporation. No precautions, other than sand filtration, are taken with regard to purification, except that a drainage system has been constructed for conveying the sewage, etc., of all houses on the area to a point below the reservoir. 
Gloucester obtains part of its water supply from two catchment areas :

1. A gathering ground of 260 acres on Robinswood Hill, an outlier of the Cotswolds, 2 miles south-east of Gloucester, between 155 and 651 feet elevation, all hill pasture except 12 acres of plantations. There are 4 farms on the area, the drainage of which is taken outside the watershed of the reservoirs; and the water is filtered before reaching the city. The Corporation own about 7 acres.

2. Witcombe gathering ground of 1500 acres, between 293 and 900 feet elevation, with three impounding reservoirs at the base of an escarpment on the northern face of the Cotswold Hills, about 6 miles east of Gloucester. The water is derived from springs thrown out at the 600 -feet contour line, just above the Lias clay. The total area comprises 12 acres of arable land, 988 acres of hill pasture, and 500 acres of plantations. There are 5 farms and Witcombe Park on the gathering ground, the sewage of which drains into cesspools. The water is filtered. The Corporation own only 42 acres. Trees do well, oak, elm, sycamore, and lime thriving on the Lias formation, and beech, pine, and larch on the Oolite. The annual rainfall, varying from 20.37 to 42.37 inches, averages about 30 inches.

Newport, Monmouthshire, obtains its water supply from two catchment areas, aggregating 3630 acres:

1. An intake at Henllys from the Pant yr eos and Henllys Brooks, with a catchment area of 2026 acres, between 123 and 1300 feet elevation, of which the Corporation own about $66 \frac{1}{2}$ acres. There are approximately 150 persons dwelling on the gathering ground, which consists of 1467 acres of mountain pasture, with some arable land, and 559 acres of plantations. There are two storage reservoirs at Rogerstone, and one at Pant yr eos.

2. Intakes at Newchurch, Wentwood, and Llanvaches, from Castrougy Nant y prydd and Llanvaches Brooks, with 
a catchment area of 1604 acres, between 450 and 900 feet elevation, of which the Corporation own about 111 acres. This gathering ground comprises 654 acres of arable land and hill pasture and 950 acres of plantations. There is one storage reservoir at Wentwood, Llanvaches.

The water is filtered, and prevention of contamination on the gathering grounds is guarded against by "constant inspection and provision of drainage."

The Corporation intend to extend their water supply by a new scheme in Brecknockshire, involving a large reservoir at Pont Rhyd y bine, $2 \frac{1}{2}$ miles from Talybont, with a catchment area of 5510 acres at Caerfanell, situated between 650 and 2500 feet elevation, none of which is owned by the Corporation. No Parliamentary powers have been yet obtained.

Tredegar Urban District Council obtains its water supply in part from the Georgetown reservoir, a mile east of the town, with a gathering ground of 160 acres, between 1200 and 1500 feet elevation, and comprising 60 acres of arable land, 40 acres of hill pasture, and 60 acres of plantations, with one farmhouse. The water is filtered.

Abertillery and District Joint Water Board obtain part of their supply from Tillery Brook, with a catchment area of 600 acres on the Blaentylery Mountain, between 1125 and 1905 feet elevation, all hill pasture and moorland. The Board own 20 acres. The water, which is filtered, is stored in the Cwmtillery reservoir, and was until lately under the control of the Abertillery Urban District Council. The Board are now constructing the Grwyne Fawr reservoir, on the Black Mountain in Brecknockshire, with a gathering ground of 2150 acres, between 1529 and 2660 feet elevation, all hill pasture and moorland, without habitations or farm-steadings.

The Bristol Waterworks Company obtain their supply from the Mendip Hills, mainly from streams, though a part is derived from springs. The Yeo reservoir on the head- 
waters of the river Yeo has an immediate catchment area of 5300 acres, on which are situated the villages of Butcombe, Nempnett, Burrington, Blagdon, Ubley, and Compton Martin. After treatment in septic tanks, the sewage from these villages is discharged on land below the reservoir. The gathering ground extends from the level of the reservoir, 110 feet, to an elevation of 1068 feet on Black Down. As the Yeo reservoir is too low for the water to gravitate to Bristol, the water is raised by pumps into the North Hill Tunnel, and thence goes by gravitation into three reservoirs at Barrow, where there are filter beds. Another catchment area to the eastward, draining the headwaters of the river Chew, is situated in Chewton Mendip, Litton, East Harptree, West Harptree, and Hinton Blewett, and is said to have an extent of 8320 acres. Its reservoirs provide compensation water. A third catchment area, tapping the Ellwell and Dundry streams, lies in Winford, Dundry, and Barrow Gurney; and on it are the three Barrow reservoirs. The average annual rainfall for 22 years varies from 35.20 inches at Barrow to 42.84 inches on Harptree Hill. I have been able to ascertain neither the acreage owned by the Company nor the proportions of arable land, moorland, and plantations on the various gathering grounds, a map of which is given in Proc. Inst. Civil Engineers, vol. 194, p. 424 (1914). Judging from the map of the "Distribution of Vegetation in Somerset," by C. E. Moss, in Geographical Journal, October 1906, the higher parts of the catchment area, over 850 feet, are heather moor or heath pasture, but these are of no great extent. The greater part of the gathering grounds is cultivated land, with some natural oak woods and scattered plantations of conifers.

Taunton obtains its water supply from three (Blagdon, Leigh, and Luxhay) impounding reservoirs, with a gathering ground of 700 acres in the Blackdown Hills, between 500 and 900 feet elevation. The area, of which 42 acres are owned by the Corporation, is made up of 100 acres of arable 


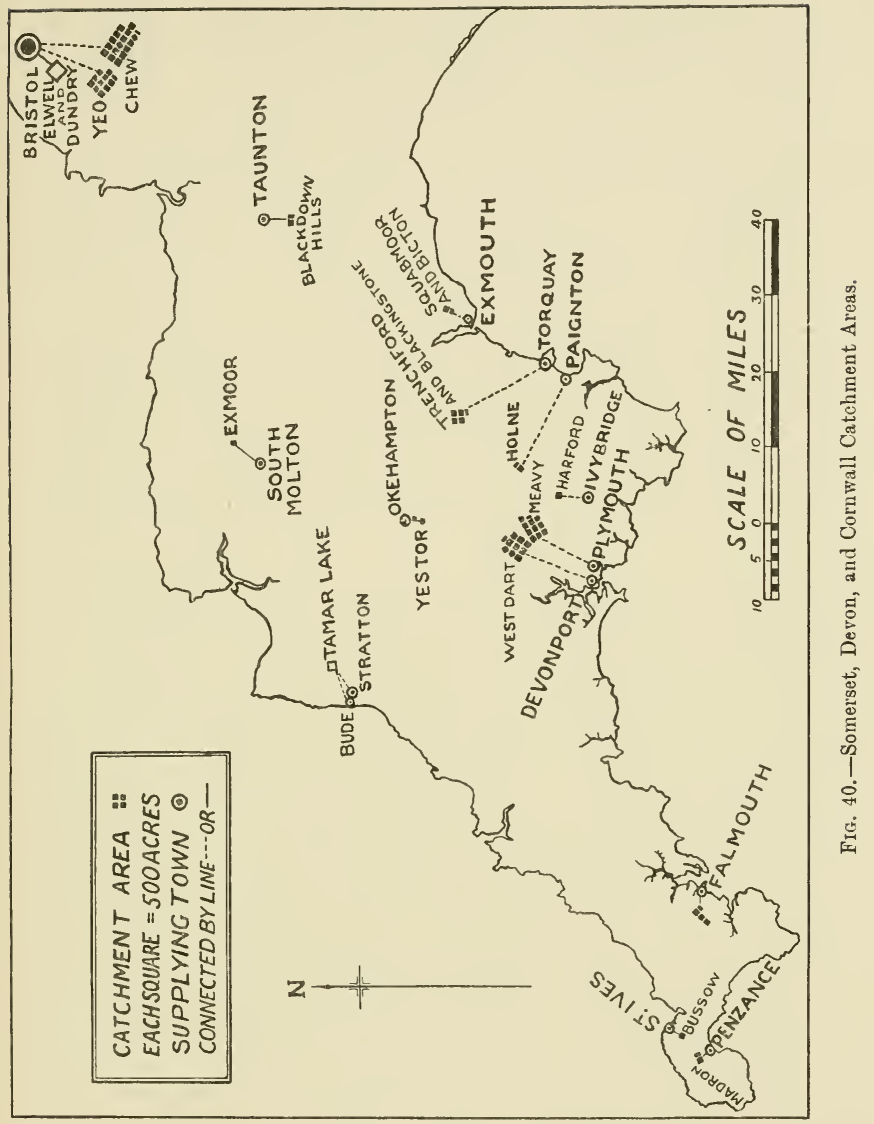


land, 50 acres of moor, and 550 acres of plantations, with two small houses upon it. The water is filtered, but "as the gathering ground is not under cultivation, no measures are necessary beyond constant supervision."

Stratton and Bude Urban District Council obtain their water supply from the Tamar Lake, supplied by overflow from the river Tamar and two small streams. The water is filtered. I have not been able to obtain any information about the gathering ground.

South Molton obtains its water supply from a gathering ground of 400 acres, at about 800 feet elevation, on North Molton Common, Exmoor. There are no dwelling-houses, farmsteads, or plantations upon the area, of which only three acres are owned by the Council. Cattle and sheep are kept from the springs and rivulets by fences. The water is not filtered.

Exmouth obtains its water supply from two gathering grounds, Squabmoor, 351 acres, and Bicton Common, 290 acres, making a total of 641 acres, situated between 264 and 550 feet elevation, and consisting of 75 acres of plantations, 74 acres of pasture and arable land, and 492 acres of common land. These areas were acquired in 1902 by the Council, who "are of opinion that no future steps are necessary to maintain the high state of purity of the water supply." The water, which is stored in Squabmoor reservoir, is filtered, and is reported by the analyst to be satisfactory ; it acts on lead, but lead pipes are not allowed. Two small additional areas of 41 and 35 acres make now the total extent of the gathering ground 717 acres. An interesting account of the geological structure and rainfall is given by Mr. S. Hutton, in Proc. Inst. Municipal and County Engineers, vol. 36, p. 132 (1910).

Plymouth obtains its water supply from the river Meavy watershed on Dartmoor, 5360 acres in extent, between 750 and 1650 feet altitude, as follows: 
Between 1500 and 1650 feet altitude

\begin{tabular}{|c|c|c|c|c|c|c|c|c|c|}
\hline & 00 & and & 00 & & & & & 84 & tres, \\
\hline & 1250 & , & 1500 & , & & - & . & 1550 & \\
\hline & 1000 & 11 & 1250 & , & & . & 0 & 2164 & \\
\hline , & 750 & , & 1000 & , & , & • & . & 1562 & , \\
\hline & & & & & & & & & \\
\hline
\end{tabular}

Practically the whole of the area is rough moorland grazing, with a few enclosed meadow and pasture lands, and 27 acres of woodland. The Town Council have purchased outright nearly the whole of the watershed, and have planted about 100,000 larch at different periods during the last twenty years. This planting has been only partially successful, owing to the rabbit pest. The Town Council are contemplating a scheme of afforestation after the war, and are being advised by Prof. Pritchard on the matter.

The Plymouth waterworks date from 1590, when Sir Francis Drake cut the open channel from Dartmoor to Plymouth, now known as the 'leat,' which conveyed the water supply for 300 years. From 1875 onwards the supply often ran short, owing to leakage from the leat, to the great increase of population, and to other causes. This led to the building of the Burrator reservoir and the conveyance of the water by pipes in 1898 . The growing inadequacy of the water supply was not due, as has been stated, to the deforestation of Dartmoor in the last 300 years. There is no evidence of the existence of woods in the Meavy drainage area in historic times. The watershed is very remarkable for its yield of water, which is greater than that of any other watershed in Britain. The whole of the catchment area, except 90 acres, is on granite, in which there are large fissures; and overlying the rock there are large tracts of peaty moorland. The rainfall is about 58 to 60 inches annually. During wet weather the peat absorbs an immense quantity of water, which is stored up in various parts of the watershed in deposits of decomposed granite, that are in some places over 100 feet in thickness. This water is yielded pure and abundant in summer, when the flow of the stream is very much larger than on watersheds, where the geological formation is more or less impervious 
to water. Disastrous floods of the Meavy river are also rare, This watershed is an exceptional case, where, without any forest cover, most of the rainfall is stored up, and little of the water passes away as 'run-off.'

Mr. J. Paton, Borough Engineer, in a discussion on pure water supply held at a meeting of the Institute of Municipal and County Engineers in 1911, comparing the gathering ground of Plymouth, owned by the Corporation, with that of Devonport, not similarly owned, says: "The water supply of Plymouth is not filtered. The source of supply is above suspicion, and there is no necessity to filter. The typhoid rate for many years has been the lowest in the country. Devonport has a gathering ground in another valley, with a great deal of peat; and the stream comes through one or two very questionable districts, where it might be liable to pollution from farm buildings, which the Plymonth supply is free from. There they do not filter, as they find it very expensive work, because the sand washing amounts to a very large sum yearly. Sand filtering does not make them any more immune from typhoid or an epidemic than if they had left it alone."

The Plymouth Waterworks are described by E. Sandeman, in Proc. Inst. Civil Engineers, vol. 146, pp. 2-42, with map (1901); and by F. Howarth, in Proc. Inc. Assoc. Municipal and County Engineers, vol. 37, pp. 95-112, with map (1911), and in Proc. Inst. Civil Engineers, vol. 194, p. 97, with map (1914).

Devonport obtains its water supply, which is now under the control of the Plymouth Corporation, from the West Dart river (1539 acres) and its tributaries, the Cowsic (1524 acres) and Blackabrook (1653 acres) rivers. The total catchment area comprises 4716 acres, of which 3297 acres are above 1500 feet, and 1419 acres lie between 1000 and 1500 feet. The area is rough moorland grazing, without any plantations of trees, and is not owned by the Corporation, who have, however, rights under Act of Parliament to abstract the water at definite points and divert it. 
A weir built across the main stream diverts the water into a leat or open conduit, which crosses the moor for many miles. The water is filtered. See Journ. Roy. Sanitary Inst. xxxiv. (1913).

Ivybridge obtains its water supply from a new reservoir on Harford Moor, Dartmoor, with a gathering ground of 414 acres, at 854 to 1200 feet elevation, all rough moorland and common lands. The Urban District Council own only the site of the reservoir and land adjoining, which is enclosed, about 8 acres. The Council have powers to enter into agreement with owners, lessees, and occupiers of any lands within the gathering ground for the execution of such works as may be necessary for draining such lands, or for more effectually preserving the purity of and collecting the water. It has not been found necessary to make any arrangements as to surface occupation.

Torquay obtains its water supply from the Trenchford and Blackingstone valleys on an outlying spur of Dartmoor on the eastern side between the Wrey Brook and the river Teign. The catchment area comprises 2331 acres, at 718 to 1135 feet elevation, as follows :

\begin{tabular}{|c|c|c|c|c|c|c|}
\hline Plantations & . & - & . & . & 284 & teres. \\
\hline Farm lands (let) & . & . & • & . & 484 & \\
\hline Arable land allowed to & run waste & . & . & & 559 & , \\
\hline Moorland and brake & .. & . & . & . & 799 & $"$ \\
\hline Roads . . & . & . & . & . & 93 & " \\
\hline Kennick, Tottiford, and & Trenchford & reservoirs & . & . & 112 & , \\
\hline
\end{tabular}

The whole area is owned by the Corporation. Originally there were 19 dwelling-houses and a population of 119 persons upon it; but all dwellings and farm buildings have been pulled down; and the greater part of the land is unused, even for grazing, 559 acres being arable land allowed to run to waste, while 799 acres are moorland.

The section of 484 acres which is let as a farm is under severe restrictions, viz.: (1) The house and farm buildings lie off the catchment area, and drain towards Wrey Brook. 
(2) All streams are strongly fenced off, and springs are carried in pipes underground so that no water lies on the surface. (3) The grazing of cattle and sheep is confined to certain areas. (4) The use of manure is limited to certain areas, and certain kinds of manure are prohibited.

Of the 284 acres of plantations, 183 acres were planted in the years 1899 to 1916 . Mr. S. C. Chapman, C.E., the able engineer in charge, has sent me a plan of the catchment area, which shows that the plantations are being made on the slopes round the reservoirs. If the flat lands beyond are ever again occupied for grazing purposes, the wide belt of trees will form a protective barrier. It is the rule to purchase 1- to 2-year-old seedling trees, which are placed in nurseries till old enough to plant out. The plantations have been successful. See Journ. Roy. Sanitary Inst. xxxi. (1910).

The Report of the Development Commissioners for 1912 1913 mentions "the application of the Torquay Town Council, on which they have agreed to approve a scheme that would ultimately provide for the planting of about 10,000 acres on Dartmoor." This scheme apparently never was proceeded with.

Okehampton obtains its water supply from two gathering grounds on Dartmoor: (1) from an intake on the Redaven stream at Yes Tor, with a catchment area of 560 acres, without any dwelling-houses or farmsteads; and (2) a gathering ground from springs, of 100 acres in Western Park, on which there are two dwelling-houses and farmsteads. The Town Council own no part of the gathering grounds, which are entirely hill pasture and moorland. The water from Yes Tor area passes through filter beds.

Paignton Urban District Council obtains its water supply from the Holne or Venford reservoir, on Holne Moor, Dartmoor, which impounds the Venford Brook, a tributary of the river Dart. It is a mile north-west of Holne, the birthplace of Charles Kingsley. The Town Council "wisely followed the admirable precedent set by Torquay, and 
purchased the catchment area, 740 acres of moorland, between 936 and 1590 feet elevation, without a habitation of any sort upon it. Commoners' rights were extinguished in respect of the land covered by the reservoir, and of 60 acres additional alongside the reservoir, which were fenced in to prevent direct pollution from cattle, etc. Owing to large patches of soft, peaty soil, the water at times has an acid reaction, and is therefore liable to act on lead." Appropriate filtration neutralises the acidity; and Paignton, a health resort with numerous summer visitors, enjoys an abundant pure moorland water supply, the cost of which amounted to $£ 119,000$, No planting has been done on the catchment area; but some larch, spruce, and Scots pine have been planted below the reservoir, which are doing well in shelter.

Falmouth Waterworks Company obtains its water supply from a gathering ground of 1858 acres, situated between 200 and 600 feet elevation, about $2 \frac{1}{2}$ miles from the town. It consists, with the exception of 200 acres of moor, of arable land and pasture, on which there are a few small farms and cottages. The Company has no control over the area, but has rights of inspection, which is regularly carried out by the Company and the Sanitary Inspector of the District. The water is filtered. There appear to be no plantations on the area, which might be afforested to preserve the purity of the water.

St. Ives obtains its water supply in part from the New Bussow reservoir, with a gathering ground on Bussow Moors, of 360 acres, between 400 and 800 feet elevation, none of which is owned by the town. The area consists of 260 acres of hill pasture and moorland and 100 acres of arable land, with several habitations and farmsteads, the drainage from which is conducted away from the streams leading to the reservoir. The water is filtered.

Penzance obtains its water supply in part from a stream gathering ground of 800 acres at Madron, between 300 and 
700 feet elevation, the whole of which is leased to the Town Council. It comprises 400 acres of arable land, with six farm-steadings, 300 acres of hill pasture and moor, and 100 acres of plantations. The water is passed through three separate layers of coke in the leats, and then in the Boscathnoe reservoirs it passes through a final filter into the service mains. Another part of the supply comes from an underground watershed of 1000 acres; and during the summer the supply is augmented by pumping from a deep well and adits. See Trans. Inst. Water Engineers, ix. (1904).

\section{WALeS}

Thirty-four local authorities and five private companies obtain their water supply from gathering grounds aggregating 147,909 acres, of which 42,273 acres are owned by eighteen Corporations. The most important areas owned by local authorities are those of Liverpool, Birmingham, Birkenhead, and Cardiff. Excellent schemes of afforestation are being carried out on the Vyrnwy area by the Liverpool Corporation, and on the Elan area by the Birmingham Corporation. Cardiff has only planted a few acres. A considerable amount of purchasable planting land exists on the Merthyr Tydfil area, but as this is not owned by the Corporation it is doubtful if any afforestation scheme will be considered. Large areas owned by Llandudno and Colwyn are too elevated to carry trees. In most of the gathering grounds in Wales, plantations on a small scale around reservoirs are possible.

The new gathering ground of Abertillery (see p. 221)2150 acres in Brecknockshire-is included in the total of 147,909 acres for Wales. The Newport (Mon.) proposed, but not yet sanctioned, area of 5510 acres in Brecknockshire is not included in this total.

Holyhead Waterworks Company obtain their supply in part from Llyn Traffwll, a lake 6 miles distant, with a gathering ground of 952 acres, situated between 


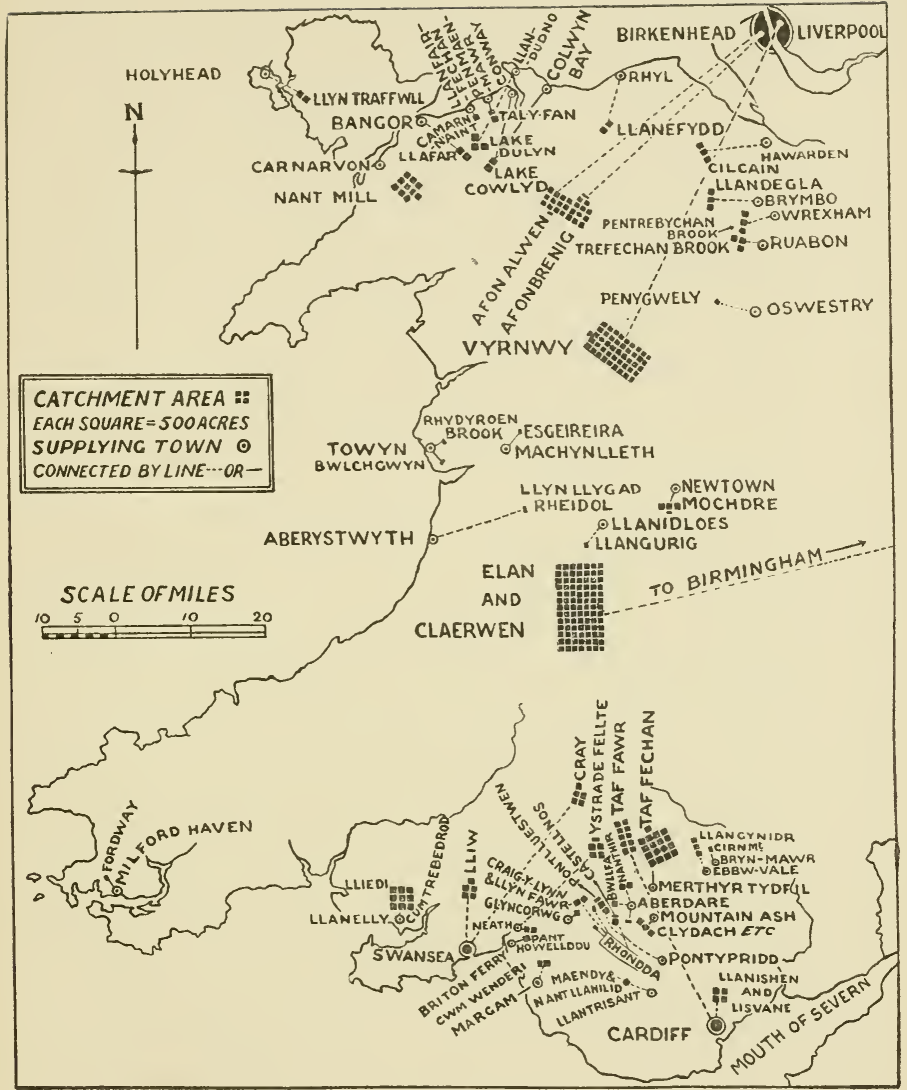

FIG. 41, - Wales Catchment Areas. 
25 and 52 feet elevation. The Company own only a small strip on the margin of the lake and the site of the pumping and filtration works. Both mechanical and sand filters are used.

Carnarvon obtains its water supply from an intake at Nant Mill, half a mile below Quellyn Lake, with a gathering ground of about 5120 acres, between $45:$ and 3500 feet elevation (Snowdon). The Corporation own only the site of the intake. The land, on which there are no plantations, is entirely hill pasture, except a very small amount of arable land. The scavenging of the village of Rhyd-ddu on the area, which has a considerable population $(200$ persons), is carried out under the supervision of the Rhydddu Joint Sanitary Committee to the satisfaction of the Local Government Board.

Bangor obtains its water supply from an intake on the river Llafar in Llanllechid, at 1300 feet elevation, with a catchment area of 1100 acres, extending up to Carnedd Llewellyn, 3484 feet elevation. The gathering ground, which is not owned by the Corporation, is without plantations, habitations, or farmsteads, and is used only for sheep grazing. The water is not filtered.

Llanfairfechan Urban District Council obtains its water supply from a storage reservoir at Camarnaint, with an intake from the Glan y Sais stream, and a gathering ground of 393 acres, between 1100 and 2000 feet elevation. The area, which is common land belonging to the Crown, is entirely hill pasture, used for grazing sheep and ponies only, and is without plantations. The water is not filtered. When sheep or ponies die on the gathering ground they are immediately buried.

Penmaenmawr Urban District Council obtains its water supply from an upland surface at Tan y Fan, reported in Journ. Board of Agriculture, xi. 471 (1904), to be 832 acres of hill pasture, between 1000 and 2000 feet elevation, all owned by the Council. The water is not filtered. 
Conway and Colwyn Bay Joint Water Board obtain their supply from Lake Cowlyd, 4 miles from Llanrwst, with a gathering ground of 1100 acres, between 1169 and 2621 feet elevation. The highest points on the gathering ground are Pen Llithrig-y-wrach (2621 feet) and Cregiau Gleision (2213 feet). The area, which is owned by the Board, includes 200 acres of lake and 900 acres of moorland, and is without habitations, farmsteads, or plantations. The water is passed through copper screens, but is not filtered; and precautions against contamination on the gathering ground are considered unnecessary. The annual rainfall from 1891 to 1906 varied between 58.50 and 114.30 inches, the average being 76.61 inches. The catchment area was purchased to do away with a farmstead that was on it, and to give the Board full control. It is now only used as a sheep-walk, and owing to its elevation and distance very few visitors find their way up there. See T. B. Farrington, in Proc. Inst. Municipal and County Engineers, vol. 33, pp. 200-207 (1907).

Llandudno Urban District Council obtains its water supply from Lake Dulyn, at 1747 feet elevation, and Lake Melynllyn, at 2094 feet elevation. The united gathering grounds, 710 acres in extent, are entirely moorland at a very high altitude, and together with 730 acres adjoining (1430 acres in all), are owned by the Council. An experimental plantation of half an acre has been made at 1650 feet elevation. The water is not filtered, but the gathering ground is frequently patrolled, twice a week in summer, and once a week in winter.

Rhyl Urban District Council obtains its water supply from a gathering ground of 900 acres at Llanefydd, between 485 and 1000 feet elevation, of which 50 acres are owned by the Council. The area comprises 100 acres of plantations, 200 acres of hill pasture, and 600 acres of arable land, with small farms upon it. The water is filtered; and on the gathering ground, the farms, which have intercepting tanks, and the streams are inspected, and excreta are 
removed. This catchment area could probably be afforested with profit, and in any case ought to be owned by the Council.

The Wrexham and East Denbighshire Water Company obtain their supply in part from the Pentrebychan Brook, with a gathering ground of 1500 acres, on the Esclusham Mountain, between 900 and 1500 feet elevation. The ground, none of which is owned by the Company, is all barren moorland on millstone grit and limestone, without houses or farmsteads. There is said to be no possible contamination. The water is first settled in an impounding reservoir at Cae Llwyd, Esclusham Above, then decanted into the Ty Mawr reservoir and finally filtered through slow sand filters.

Birkenhead obtains its water supply at present from wells and borings in the New Red Sandstone formation; but an additional source of supply from a gathering ground of 6300 acres on the head-waters of the river Alwen in Denbighshire was authorised by the Birkenhead Corporation Water Act of 1907; and the necessary works, including reservoir, mechanical filters and tanks, are now being constructed. The Alwen catchment area is situated between 1190 and 1760 feet elevation, and consists mainly of moorland, more or less covered with peat, which varies in depth from a few inches to many feet. Below the peat on the south and west is generally boulder clay; elsewhere rock and shale prevail. About 550 acres only may be classed as arable and grass land, there being a little cultivation on the north and east sides of the watershed, and about 100 acres of woods and plantations on the north-east side of the valley. There are eleven houses and farmsteads on the gathering ground, five of which belong to the Corporation; and of the latter, two near the margin of the reservoir will probably remain uninhabited.

The Corporation own 2600 acres, including some land below the reservoir, that drains to the river Alwen. Of this area, about 375 acres are covered with the water of the reservoir. Prof. Fraser Story estimates that about 
600 acres of the Alwen area might be profitably afforested. The afforestable area faces north and east, excellent shelter being afforded by a ridge which runs parallel to the lake. The range of hills, composed of Craig-yr-Tychen, Ten-ybwlch, Mwdwleithin and Pen-bwlchygarnedd, is situated immediately to windward. The sheltered situation counteracts to a great extent the influence of the high elevation, 1200 to 1500 feet. Many parts, chiefly near the sources of small streams and in the hollows, covered with accumulations of peat, must be excluded from any scheme of afforestation. The area previously occupied by Llyn Dauychain, in which the peat from the bottom of the reservoir was deposited, and some swampy land, must also be excluded. The soil is suitable for the growth of spruce, especially Sitka spruce; and some of the lower slopes might be advantageously planted with Douglas fir. About 75 per cent of the west side could produce timber profitably. The cost of planting, including young trees, drainage, and ordinary fencing, was estimated in 1915 at $£ 6$ per acre. The annual rainfall was about 46 inches in 1911,1912 , and 1913 , and 55.12 inches in 1914 .

The Corporation have authority to construct another reservoir in the Brenig Valley in Denbighshire, having a separate gathering ground adjacent to the Alwen watershed, 5600 acres in extent, and situated between 1067 and 1700 feet altitude. This catchment area, of which the Corporation own about 4400 acres, will not be utilised at present for water supply; and no report as regards its suitability for afforestation has yet been made.

Brymbo Water Company obtain their supply from three upland surfaces, 686 acres and 873 acres at Llandegla, and 42 acres at Llanarmon, making a total of 1601 acres. I have not been able to obtain any particulars of these gathering grounds, which appear to be mainly moorland and hill pasture. The water is filtered.

Ruabon Water Company obtain their supply from an intake of the Trefechan Brook on the Ruabon Mountain, 
west of the village of Pen $y$ Cae, with a gathering ground of 1565 acres. I have not been able to obtain any particulars of this area, which appears to be all moorland and hill pasture. The water is filtered.

Oswestry obtains its water supply from Penygwely reservoir, $5 \frac{1}{2}$ miles distant and near Llansilin in Denbighshire, with a gathering ground of 455 acres, at 1100 to 1467 feet elevation, consisting mainly of hill pasture and sheep-run withont any habitations. The Town Council in 1904 purchased the farm of 250 acres on which the impounding reservoir is situated and which comprises the greater part of the watershed. It includes 30 acres of arable land; but there is little or no danger of contamination. The water is not filtered, but is of good quality. There are no trees on the area; but in the adjoining watershed to the north there are large plantations ranging in elevation from 1000 to 1380 feet and from 1400 to 1470 feet. The annual rainfall at the reservoir averages 40 inches. The Borough Surveyor, Mr. G. W. Lacey, is of opinion that in general the control of the catchment area should be in the hands of the Water Authority.

Hawarden and District Waterworks Company obtain their supply from four storage reservoirs at Cilcain, with a gathering ground on the Garth Stream, Moel Famma, of 1400 acres, between 750 and 1640 feet elevation. The area, which is entirely hill pasture and moor, is not owned by the Company. The water is filtered; and no special precautions against contamination are considered necessary.

Towyn Urban District Council obtaius its water supply from (1) Rhydyronen Brook, with a gathering ground of 215 acres, comprising 179 acres of hill pasture, 30 acres of arable land, and 6 acres of plantations; and (2) Bwlchgwyn, springs and gathering ground of 57 acres, comprising 47 acres of hill pasture and 10 acres of arable land. In Journ. Board of Agriculture, xi. 471 (1904), 217 acres are said to be owned by the Comncil. 
Vyrnwy catchment area, 22,742 acres, supplying Liverpool, and with a good scheme of afforestation, is fully described on pp. 88-94.

Machynlleth Urban District Council obtains its water supply from Esgeireira reservoir, Llanwrin, with a gathering ground of 271 acres, reported in Journ. Board of Agriculture, xi. 471 (1904), to be owned by the Council, and to comprise 204 acres of hill pasture and 67 acres of woodland. The Clerk states in a letter that only $3 \frac{1}{2}$ acres are owned by the Council.

Llanidloes obtains its water supply from a gathering ground of 260 acres at Llangurig, all hill pasture and moorland. None of it is owned by the Town Council. The water is filtered, but no other precautions are taken against contamination.

Newtown and Llanllwchaiarn Urban District Council obtain their water supply from Mochdre reservoir, with a gathering ground of 1821 acres, between 662 and 1391 feet elevation, in Mochdre and Kerry. The total area, of which only 10 acres are owned by the Council, comprises 334 acres of arable land, 1377 acres of hill pasture and moor, and 110 acres of plantations. There are 17 farm-steadings on the gathering ground, and a careful inspection is made monthly of each farm. Cesspools are provided to prevent the sewage getting into the intake stream; and no flood water is taken into the reservoir. This area would seem to be suitable for an afforestation scheme, which would do away with the arable land and farm-steadings, and prevent possible contamination.

Aberystwyth obtains its water supply from Llyn Llygad Rheidol, a small lake or tarn just below the summit of Plynlimmon, with a gathering ground of 133 acres, between 1665 and 2468 feet elevation, all moorland without any habitations, and not owned by the Town Council. There is no filtration. 
Elan and Claerwen area, 45,562 acres, supplying Birmingham, and with a good afforestation scheme, is fully described on pp. 101-104.

Milford Haven Urban District Council obtains its water supply from three reservoirs at Fordway, with a gathering ground of about 200 acres, between 92 and 190 feet elevation. This area is leased by the Council, and comprises 40 acres of arable land, 155 acres of hill pasture and moor, and 5 acres of plantations. There are some habitations and farm-steadings on the gathering ground; and to deal with the contamination from these, a system of drainage with cesspits and small filters was adopted, which is reported to be satisfactory.

Llanelly obtains its water supply from two gathering grounds with a total extent of 4398 acres :

1. Lliedi Valley, with two reservoirs, 4048 acres, between 200 and 950 feet elevation, comprising 400 acres of arable land, 3000 acres of hill pasture and moor, and 648 acres of plantations.

2. Cwm Trebeddrod, with one reservoir, 350 acres, between 200 and 550 feet elevation, comprising 50 acres of arable land, 250 acres of hill pasture, and 50 acres of plantations.

On the Lliedi area, there are 509 inhabitants and 102 dwelling-houses and farmsteads; and the Corporation own only 100 acres in all. On the Cwm Trebeddrod area there are 50 inhabitants and 10 dwelling-houses and farmsteads, and the Council own only 15 acres.

The risk of contamination would appear to be great, but stringent bye-laws for the prevention of pollution have been made under section 25 of the Llanelly Waterworks Act, 1909. "The gathering ground is inspected, and all sanitary arrangements in the houses on the area are kept under supervision. The farmyards are drained on to adjoining lands and the watercourses are kept clear." The bye-laws provide that sanitary arrangements shall be made by owners and occupiers of lands on the drainage area. No pigs may 
be kept. The grazing of eattle is not allowed within 100 yards of the streams. The water is filtered.

Cardiff obtains its supply of domestic water at present from a gathering ground of 4000 acres, at the head of the Taff Fawr River in Brecknockshire. There are two reservoirs, Beacons reservoir at 1340 feet and Cantreff reservoir at 1073 feet elevation, the highest point on the area being Brecon Beacons, 2910 feet. The Council have purchased 728 acres of this area, and have planted 25 acres with trees up to February 1918. "Prof. Fraser Story advised the Council regarding afforestation; and a deputation was sent to interview the Development Commissioners, but little help or encouragement was given at the time." Upon the parts privately owned, there are no buildings except a house belonging to the Corporation, and steps are taken to prevent any contamination. Adjacent to the preceding gathering ground is the lower catchment area of Taff Fawr, on which the Llwynon reservoir is being built at 850 feet elevation; but the work of construction was stopped in November 1915 . This area comprises 6000 acres, between 850 and 2000 feet elevation, and of it 1248 acres are owned by the Corporation. The average rainfall varies from 76.96 inches at the Beacons reservoir to 60.31 inches at the Llwynon reservoir. The water is filtered.

Cardiff has also another gathering ground, with two reservoirs at Llanishen and Lisvane, about four miles north of the city, comprising 2000 acres mainly over limestone, mostly arable land with some pasture and woods, extending on the north to the Caerphilly hills and on the east to Cefn Mably Park. Recently considerable building has taken place of a suburban character. The Corporation own no part of this area, the water of which has not been utilised for domestic purposes for many years past. Owing to the non-completion of the Llwynon reservoir, the Lisvane gathering ground may shortly be used to supplement the water from the Taff Fawr; and this would entail steps being taken to prevent contamination of the water of the several streams. 
Merthyr Tydfil obtains its water supply from a gathering ground of 8350 acres in Brecknockshire, comprising the area draining to the river Taf Fechan from the Brecon Beacons southwards to Pontsticill, where the Taf Fechan reservoir is now being constructed across the river valley. The area lies between 1082 and 2906 feet elevation. The area owned as freehold by the Corporation is 623 acres, of which $420 \frac{1}{2}$ acres are under water, while $202 \frac{1}{2}$ acres are enclosed land around the margins of the reservoirs, viz. :

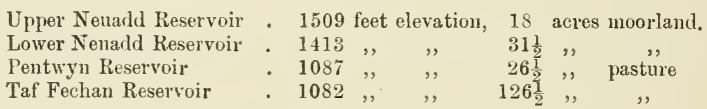

Around the three first reservoirs the Corporation have planted 70 acres; and "conifer plantations and quickset hedges have proved successful at an elevation of 1500 feet, which does not appear to be the limiting altitude for successful afforestation."

In a report, dated 26th August 1914, Mr. T. Harvey, M.Inst.C.E., states that " of the total area, more than 6000 acres are mountain moorland, mostly commonable lands, the greater part of which is on the Old Red Sandstone, and eminently adapted for a scheme of afforestation. About 1500 acres in the Taf Fechan Valley, adjoining the reservoir lands, are enclosed lands, cultivated by various landowners, who use the 6000 acres of mountain moorland within the catchment area for sheep-runs and for cattle grazing. A proportion of the mountain land, perhaps 1000 acres or more, could with advantage be enclosed and planted in a series of belts, leaving the intervening spaces for sheep grazing; and after a period of years the trees would afford shelter. The subsoil over a large portion of the 6000 acres is of a considerable depth, but near the summit of the hills the rock crops out in escarpments and on the surface. At Blaentaf Farm, nearly 1400 feet above sea-level, large and well-grown ash trees and sycamores may be seen. In my opinion, the afforestation of the moorland, comprising the 
larger part of the catchment area, would prove advantageous in every respect and ultimately profitable."

The catchment area was subsequently reported upon by Mr. H. A. Pritchard, Adviser in Forestry, who spent some days in a detailed examination of the ground; but whether any steps will be taken for its afforestation after the war, in the absence of ownership by the Corporation, is uncertain.

The population on the gathering ground, which contains no arable land, is very small; and the only measure taken against possible contamination has been the carrying out of some drainage to farms near Pentwyn reservoir. The water is filtered. The rainfall on the catchment area is high, ranging from 44 to 72 inches at Pentwyn reservoir. For further particulars see Mr. T. F. Harvey, in Proc. Inc. Assoc. IIunicipal and County Engineers, vol. 26, pp. 46-49, with map and plans (1900).

Neath Rural District Council obtains its water supply from Ystradfellte reservoir on the river Dringarth in Brecknockshire, with a gathering ground of 2250 acres, between 1204 and 2000 feet elevation, all hill pasture and moor, without habitations or farm-steadings. The Council owns 85 acres only. The water is not filtered, but caretakers make daily inspection of all sources of supply.

Ebbw Vale Urban District Council obtains its water supply from the Llangynidr and Carno reservoirs, on the river Ebbw, with a gathering ground of 1530 acres on the Llangynidr mountain in Brecknockshire, between 1356 and 1771 feet elevation. The area, none of which is owned by the Council, is all hill pasture and moorland, without habitations, farm-steadings, or plantations. The water is filtered, but no special precautions are taken against contamination on the gathering ground. The average annual rainfall is 60 inches.

Brynmawr Urban District Council obtains its water supply from a gathering ground of 200 acres on Cirn Mountain 
(Brecknockshire), a mile north of the town, between 1400 and 1600 feet elevation. The area is all hill pasture and moor, without habitations or farm-steadings; and the Council owns only 7 acres, the site of the impounding reservoir and filter beds. No precautions are considered necessary against contamination of the gathering ground.

Swansea obtains its water supply from two catchment areas, aggregating 5156 acres:

1. Lliw or Velindre area, 2476 acres, between 416 and 1226 feet elevation, with Lower Lliw, Upper Lliw, and Blaenant Dhu reservoirs. The gathering ground, on the head-waters of the Lliw River, comprises 2144 acres of hill pasture and moor, 193 acres of arable land, 115 acres of reservoir sites and works, and 24 acres of plantations, recently felled. Only 147 acres are above the 1000 feet contour line, being unenclosed mountain pasture. There are on the area eighteen farmsteads and habitations, the drainage of which is distributed over the land by irrigating channels; and two contaminated streams, which intercept the drainage of nine habitations, are conveyed by pipes below the reservoir embankment.

2. Cray area, 2680 acres, between 1000 and 2380 feet elevation, all hill pasture and moorland, except six acres of plantations and 124 acres of reservoir site and works. No less than 1250 acres are above the 1500 feet contour line. The catchment area, comprising the head-waters of the Cray River, is in Brecknockshire, about 30 miles from Swansea. On the area there are two shepherds' cottages, the drainage of which is conveyed below the Cray reservoir by the byewash channel. The annual rainfall on the area varied in 1915 from 63.90 inches at 1030 feet to 85.50 inches at 2170 feet altitude.

As there is no filtration, in addition to the precautions taken with regard to sewage of habitations, constant patrols are in operation on both catchment areas; and any dead sheep are collected and properly disposed of by arrangement with the farmers. 
Of the Lliw area, the Corporation own 215 acres, of which all but about 100 acres is occupied by reservoir sites and works. Of the Cray area, the Corporation own 174 acres, of which all but 50 acres is occupied by reservoir site and works. There would thus be in the two areas about 150 acres of land owned by the Corporation available for afforestation. This 150 acres is below 1200 feet elevation. Mr. G. R. Collinson, the Water Engineer, is of opinion that "the catchment areas, comprising principally mountain pasture, seem to be lands which, in the event of the State acquiring land for afforestation, could be more valuably used for that purpose than remain in their present condition. The few plantations that exist seem to indicate that afforestation on an extensive scale and under proper management could not fail to be successful. Unless the Government can, however, obtain land more advantageously than public authorities seem to be able to do so for public purposes, State afforestation schemes would have to be developed on very uneconomic lines."

The Swansea water supply is described by R. H. Wyrell, C.E., in Proc. Inc. Assoc. Municipal and County Engineers, vol. 32, pp. $61-70$ (1906).

Margam has a gathering ground of 1000 acres, at 400 to 1000 feet elevation. None of the area is owned by the Corporation except the site of the impounding reservoir at Cwm Wenderi, $10 \frac{1}{2}$ acres in extent, which is held on a lease of 999 years. There are no habitations or farm-steadings on the gathering ground, which is frequently inspected. The water, which is not filtered, is frequently analysed.

Neath receives its water supply from a gathering ground of 843 acres, situated to the east of the town, between 200 and 1000 feet elevation. The area, none of which is owned by the Town Council, comprises 80 acres of arable land, 533 acres of hill pasture and moor, and 230 acres of plantations; and upon it there are the five farms of Brynau, Glannant, Cefn-Saeson, Crynallt, and Preswylfa. The water is filtered, and certain drainage arrangements have been 
made on the gathering ground, which would seem to be suitable for an extensive scheme of afforestation.

Briton Ferry Urban District Council obtains its water supply from a gathering ground of 240 acres on Pant Howellddu and Cefn Coed Mountain, between 500 and 1000 feet elevation, comprising 60 acres of arable land, 140 acres of hill pasture, and 40 acres of plantations. The area, of which the Council owns 19 acres, has four dwelling-houses and farmsteads upon it. It is systematically inspected and the water is filtered.

Glyncorwg Urban District Council obtains its water supply in part from the Nantryallor Brook, with a gathering ground of 550 acres, situated close to the town, between 900 and 1000 feet altitude. The whole area is leased by the Council and consists of hill pasture and moor, without houses, farm-steadings, or plantations. The water is not filtered, but the gathering ground is periodically inspected to guard against contamination.

Pontypridd and Rhondda Joint Water Board obtain their water supply in part from (1) Pontlluestwen reservoir, with a gathering ground of 1484 acres, between 1336 and 1678 feet elevation, at the head of the valley of the Rhondda Fach (Ordnance Survey, Glamorgan Sheet, xi. 13), and (2) Castell Nos reservoir, lower in the same valley, with a gathering ground of 682 acres, between 1110 and 1695 feet elevation. The two areas, comprising 2166 acres, are entirely moorland, and without houses, farmsteads, or plantations. The Board own only the sites of the reservoirs, and a narrow strip around them. The water is filtered, and no other precautions against contamination are taken.

Mountain Ash Urban District Councll obtains its water supply from five gathering grounds:

\begin{tabular}{|c|c|c|c|c|c|c|c|c|}
\hline Clydach Brook & . 205 & cres, & between & 932 & and & 1548 & feet & \\
\hline Sychnant Brook & . 566 & ", & " & 950 & ", & 1351 & ," & ", \\
\hline Nantyrisfa . & 165 & ," & ", & 950 & ", & 1278 & ," & " \\
\hline Darenlas & 329 & , & ", & 600 & , & 1300 & $"$ & $"$ \\
\hline Ffrwd Brook & . 170 & $"$ & ," & 700 & 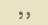 & 1462 & $"$ & , \\
\hline
\end{tabular}


The total, 1435 acres, of which the Council owns only 40 acres, situated on the Clydach area, consists of 1085 acres of very hilly pasture and moorland, grazed by a few mountain sheep, and 350 acres of plantations. On this account the risk of contamination is considered negligible, and no special measures against it are taken. There are three storage reservoirs, Perthgelyn, Clydach Ynysybwl, and Darenlas; and only the water from the Darenlas reservoir is filtered.

Rhondda Urban District Council obtains its water supply from :

1. An intake on the upper course of the Rhondda River, at 1250 feet elevation, with a gathering ground of 820 acres, rising to 1969 feet altitude (Craig-y-llyn). The weir formerly on the Rhondda River is no longer used.

2. Llyn Fawr, a lake which has been converted into a reservoir of 200,000,000 gallons capacity, with a catchment area of 247 acres, situated between 1208 and 1969 feet elevation.

3. Nant Ystrad Ffernol, with a gathering ground of 237 acres, between 1000 and 1690 feet elevation.

4. Nant Selsig, Tyisaf Mountain, with a gathering ground of 358 acres, between 900 and 1600 feet elevation.

The total area, 1662 acres, none of which is owned by the Council, is hill pasture and moorland, grazed only by sheep, and without houses or farmsteads. The water is filtered, and the gathering ground is periodically inspected. Besides Llyn Fawr, there is a small storage reservoir at Tynywaun near Treherbert.

Aberdare Urban District Council obtains its water supply from three gathering grounds, totalling 1995 acres in extent :

Nanthir and Nantmoel reservoirs, with a catchment area of 1075 acres, between 900 and 1250 feet elevation, about 4 miles north of Aberdare.

Bwllfa reservoir, with a catchment area of 570 acres, 
between 800 and 1450 feet elevation, about $2 \frac{1}{2}$ miles to the west of Aberdare.

Pwllfa reservoir, with a catchment area of 350 acres, between 1100 and 1550 feet elevation, about 3 miles to the south of Aberdare.

The District Council do not own and have no control over these areas, which consist entirely of mountain land, mostly sheep pasture, and free from any habitations or farmsteads. The water is filtered. No special measures against contamination are taken on the gathering grounds.

Llantrisant and Llantwitfardre Rural District Council obtain their water supply in part from (1) a gathering ground of 66 acres at Maendy, all moorland, and between 950 and 1280 feet elevation; and (2) a gathering ground of 409 acres at Llanillid, between 575 and 985 feet elevation, all moorland except $13 \frac{1}{2}$ acres of arable land. There are no habitations or farmsteads on the areas, which are not owned by the Council. The Llanillid water is filtered, and periodical inspection of both areas is made. 


\section{CHAPTER XI}

\section{WATER CATCHMENT AREAS IN SCOTLAND}

As no official publication on the water supplies of Scottish municipalities has yet appeared, the following account of the principal gathering grounds of Scotland will be of interest. This information is the result of queries addressed to the town clerks and burgh surveyors, and would have been more complete but for the stress of war time. Attention is again drawn to the fact already mentioned that so few of these gathering grounds are owned by the Corporations. This is the more to be regretted, as in Scotland, owing to the proximity of these areas to industrial centres, their afforestation, an easy matter in many cases, if they ivere publicly owned, would be certain to prove remunerative. It will also be seen that the sanitary precautions taken on the areas that are privately owned are often insufficient to prevent contamination of the water supply. The compulsory public ownership of the gathering grounds in Scotland would then seem to be necessary, both for the purpose of enforcing adequate sanitary control of the water supply, and as a means of increasing the reserves of growing timber in the country.

The 78 local authorities in Scotland, from whom reports have been received, obtain their water supply from gathering grounds which aggregate 243,624 acres in extent. Only 16 local authorities, namely, Edinburgh, Dundee, Paisley, Clydebank, Ayr, Dalry, Mid Lanarkshire, 
Airdrie and Coatbridge, Bo'ness, Kirkcaldy and Dysart, Newburgh, Lauder, Turriff, Kingussie, Tain, and Kirkcudbright, own or hold on long lease their catchment areas in whole or part, the total amount of land in their possession being reported as 27,829 acres. These figures are not exhaustive,

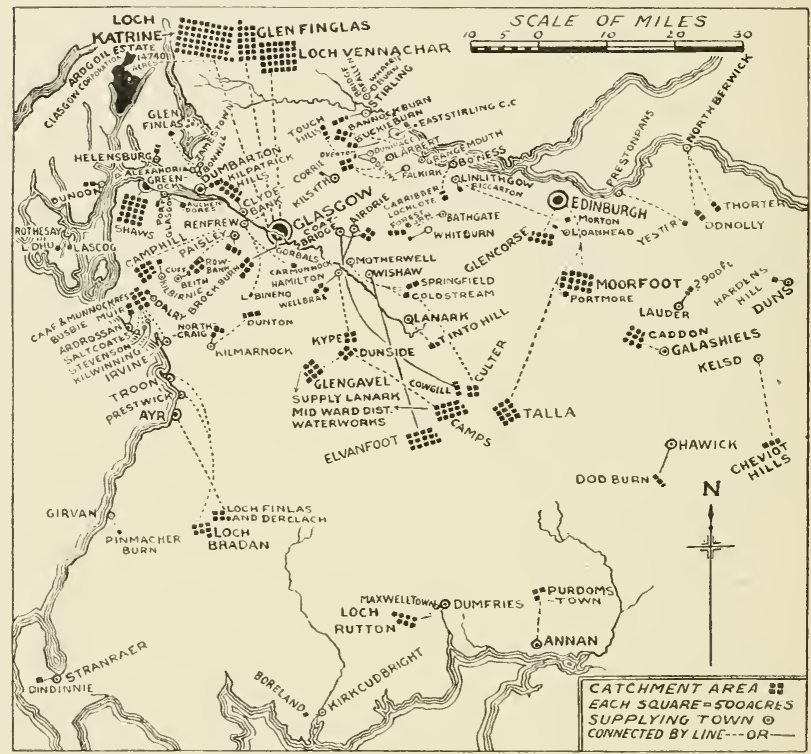

Frg. 42.-West, Central, and South Scotland Catchment Areas.

as they do not include the small areas owned as reservoir sites by some of the local authorities.

Afforestation is being carried out by Edinburgh on the Talla area, by Dundee on the Lintrathen area, and by Mid Lanarkshire on the Camps area, and special attention may be directed to the excellent scheme of the last-named authority, which is described on p. 29. On the other 
owned areas, there are scarcely any woods, and no plantation schemes are in contemplation.

\section{Perth (West), Dumbarton, Argyll, Bute, and Renfrew Counties}

Gathering grounds, 59,513 acres, supplying eleven local authorities; 3543 acres owned by two local authorities.

Glasgow obtains its water supply from two sources, Loch Katrine and the Gorbals Waterworks. Loch Katrine, situated in the Highlands, 34 miles to the north, provides the greater part of the city of Glasgow, as well as Renfrew and several small towns and villages, with a remarkably pure and abundant supply of water. The original level of the lake was raised by embankment 9 feet, so that it now has 3000 acres of water surface. An additional supply to Loch Katrine is brought by a tunnel from Loch Arklet, which has been raised 22 feet above its original level and increased in surface from 217 to 551 acres by works begun in 1909 . The water undergoes no filtration, being merely strained through fine wire-gauze netting to prevent the passage of sticks and leaves into the pipes. The Loch Katrine catchment area, including the Loch Arklet area, is 27,312 acres in extent, and consists of uncontaminated sparsely populated moorland, with a great deal of peaty surface. The ownership of the whole gathering ground remains in private hands; but in order to secure the water supply from pollution, the feuing rights over the entire drainage to Loch Katrine and Loch Arklet were purchased by the Corporation at a cost of $£ 18,300$; and the owners of the land within that area are prohibited from erecting houses or buildings on any part of the gathering ground.

The Glasgow Corporation also utilise Loch Vennachar, including Loch Drunkie, with a total catchment area of 24,686 acres, for compensation water. Recently the gathering ground of Glenfinlas, 9600 acres, which forms 
part of the Loch Vennachar area, has been set aside to provide at a future date an additional water supply to Loch Katrine for consumption in Glasgow. In view of this, the Corporation in 1915 paid $£ 30,250$ to the Earl of Moray, and $£ 2250$ to the Commissioners of Woods, in respect of the Crown interests in the Royal Forest of Glenfinlas, or $£ 32,500$ in all, for freehold and wayleaves in Glenfinlas for additional waterworks, including obligation on the part of the owners to erect no buildings on the gathering ground of 9600 acres to the intended reservoir.

The Gorbals Waterworks obtains its supply from the Brock Burn, about 6 miles south of Glasgow. The water is impounded into the Balgray, Ryat Linn, Waulkmill, and Littleton reservoirs, situated at 296 to 352 feet elevation. The gathering ground, which is within the agricultural zone, is 2560 acres in extent. The Corporation have acquired only the water rights of this area. The water is passed through two sets of filters.

No proposals have been made as regards the afforestation of either the Loch Katrine or Gorbals water catchment areas, neither of which is owned by the Glasgow Corporation.

Helensburgh obtains its water supply from a small stream provided with a weir at 570 feet elevation. The gathering ground, about 800 acres of hill pasture, extends from this elevation up to 2100 feet, 110 part of it being owned by the Corporation. There are three storage reservoirs, the water of the two largest of which is screened and filtered, and of the smallest is screened but not filtered. No other measures are taken against contamination.

Alexandria, Bonhill, and Jamestown District Council obtain their water supply from Glen Finlas reservoir, with a gathering ground of 440 acres, entirely hill pasture, situated between 1600 and 2000 feet elevation. Of the total area, which is without houses, farm-steadings, or plantations, the Council own 40 acres. No precautions are necessary against contamination of the water. 
Dumbarton obtains its water supply from three catchment areas in the Kilpatrick Hills, aggregating 1273 acres :

1. Lochs Humphry and Fyn, 522 acres.

2. Black Linn, 111 acres.

Both areas at 1051 to 1200 feet elevation; hill grazing and grouse moor.

3. Overton Glen, 640 acres, at 500 to 1050 feet elevation; grazing and game preserves, slightly wooded.

The Town Council do not own the areas, and have control over the water rights only. There are no farmsteadings; and consequently no measures are needed, it is said, to prevent the pollution of the water. The Town Clerk does not think that it would be in the interest of the Corporation to acquire the ownership of the lands, looking at the price which would require to be paid for them.

The Clydebank and District Water Trust is the local authority for the supply to the Burgh of Clydebank and the villages of Duntocher and Hardgate. There are five catchment areas, viz. :

Catchment Area.

Loch Cochno

Jaw Reservoir

Greenside Reservoir

Burncrooks Reservoir

Finland Burn

\section{Aeres.}

361

229

855

1070

1190
Altitude in Feet.

881.1082

$881-1170$

$830-1250$

820-1171

820-1163

all situated in the Kilpatrick Hills, mostly covered with peat, grazed by sheep, and without any human habitations. The water, otherwise pure, is stained a peaty colour, which is removed by the filters at Cochno. The annual rainfall in 1912 was 51.48 inches. The lands of Cochno, Jaw, and Greenside reservoirs are held by payment of a yearly feuduty; while the Finland Burn area is owned by the Trust for the purposes of the Water Supply Act of 1906. No planting scheme has been contemplated, as the ground, which is without any trees, is considered to be unsuitable for afforestation. 
Dunoon obtains its water supply from a gathering ground behind the reservoir at the west end of the burgh. It is hill pasture grazed by sheep, and comprises 1100 acres between 242 and 1651 feet elevation. As there are no farm-steadings or habitations on this area, there is little risk of contamination of the water, which is filtered. The Town Council do not own the land, which is without trees. The annual rainfall in 1912 was 96.8 inches.

Rothesay obtains its water supply from Loch Ascog and Loch Dhu, with a catchment area of 919 acres, between 120 and 450 feet elevation. The Corporation own no part of the area, which is made up of 261 acres of arable land, 511 acres of hill pasture, and 147 acres of plantations. There is one farm-steading on the gathering ground. The water is filtered, but no other measures are taken to prevent contamination.

Greenock is supplied by the Shaws Waterworks, which have a catchment area of about 10,000 acres in the hills south of the town, extending to Kelly Dam (640 feet altitude), Knockencorsan (1040 feet), Creuch Hill (1446 feet), and Duchal Moor (1150 feet). Although a considerable part of the area lies between 500 and 1000 feet elevation, it is practically all upland moorland, with scarcely any trees, and is said to be free from risk of contamination. The chief reservoirs are Loch Thom (also known as Shaws Water), Gryfe reservoir, and Compensation reservoir. The Corporation have merely acquired the rights of the area, and own only the sites of the reservoirs.

Port Glasgow obtains its water supply from two catchment areas :

1. Auchendores and Leperstone reservoirs; gathering ground at 500 feet elevation, comprising 467 acres of arable land and pasture, and 23 acres of plantations, 490 acres in all.

2. Knocknairshill and Dougliehill reservoirs; gathering 
ground at 700 feet elevation, comprising 35 acres of arable land and pasture, and 75 acres of wood and moorland, 110 acres in all.

On the catchment area of the Auchendores and Leperstone reservoirs, which are contiguous, there are several farm-steadings, the drainage of which is diverted past the reservoirs by a pipe drain. There are arable fields adjoining the reservoirs; but the possible contamination from these is not considered very serious. The Town Council possess only the water rights over the two gathering grounds, and have no control as to how the land is to be used.

The District Committee of the First or Upper District of the County Council of Renfrew obtain their water supply from two gathering grounds. The Carmunnock Works, which include three reservoirs, are situated on the Highflat Burn in Carmunnock Parish, Lanarkshire, and have a catchment area of 500 acres, at 565 to 691 feet elevation, none of which is owned by the Committee except the sites of the reservoirs. The area, on which there is one farm, is made up of 20 acres of water, 440 acres of arable land, 25 acres of plantations, and 15 acres of hill pasture. The Bennan (or Binend) Loch gathering ground, in Renfrewshire, comprises 275 acres, at 840 to 960 feet elevation, of which 85 acres under water are owned by the Committee. The remainder, 190 acres, is hill pasture, privately owned, and without any farmsteads. The Committee also own 70 acres, the site of Lochcraigs reservoir, not yet constructed. This reservoir will have a catchment area of 405 acres, at 805 to 895 feet elevation, all hill pasture, privately owned, and with only a shepherd's cottage upon it.

Paisley obtains its water supply from three catchment areas, aggregating 7746 acres in extent. . (1) The collecting ground of the Camphill reservoir, 4257 acres, between 600 and 1584 feet elevation, lies on the hills of northern Ayrshire, and is fed by the burns at the head of Rye Water from Camphill to Black Law and Irish Law. It is mostly 
rough hill pasture under sheep grazing, with a few acres only of peat and plantations. (2) The Rowbank and Barcraigs reservoirs in Renfrewshire have a gathering ground of 2263 acres, under 750 feet elevation, and mostly rough hill pasture with a few acres only of wood and arable land. (3) The Stanely, Glenburn, and Harelaw reservoirs, a short distance south of Paisley, have a gathering ground of 1226 acres, under 750 feet altitude, and nearly all rough pasture, with very little peat and only a few acres of wood. The Council have water rights over the three catchment areas; and in connection with the disposal of sewage, have acquired ownership of some of the farms, viz. : 558 acres on the Rowbank and Barcraigs area, and 350 acres on the Stanely area. On the land owned within the areas by the Corporation there are no occupied houses. On the land controlled by the Corporation, 200 acres on the Rowbank area, restrictions are imposed as to manuring; and no cropping or ploughing is allowed. On the farms not owned by the Corporation, arrangements when possible are made with the farmers or proprietors to lay the drains in such a position that they will lead the sewage clear of any of the water courses feeding the reservoirs. In cases where this method cannot be carried out owing to unsuitable levels, watertight tanks or reservoirs are constructed to which the sewage is conveyed; and a pump and handcart are given to the farmer by the Corporation, and he arranges to empty the tank or cesspool as required. The water supply is filtered.

\section{Ayr, Wigtown, Kirkcudbright, and Dumfries Counties}

Gathering grounds, 24,817 acres, supplying thirteen local authorities (Camphill area supplying Paisley included; Kilbirnie area not included, as its acreage is unknown). 3094 acres owned by three local authorities.

Ardrossan obtains its water supply from four impounding reservoirs, Busbie Muir, Mill Glen, Whitelees, and Park- 
house, with a gathering ground of about 1000 acres, between 80 and 700 feet elevation; and of this about 5 acres are under plantations. The Corporation, who only own the sites of the reservoirs, are unable to take any special measures against contamination on the catchment area. The water is passed through sand filters.

Beith obtains its water supply from Kirklugreen and Cuffhill reservoirs, with a gathering ground of 290 acres, at Cuff and the surrounding hills, between 464 and 680 feet elevation. The County Council own only the sites of the reservoirs, about 18 acres fenced in, and have no control over the remaining 272 acres, except the protection against pollution given by the Public Health (Scotland) Act, 1897, and the Waterworks Clauses Act, 1847. Of the gathering ground, 57 acres are plantations, and 219 acres are mostly hill pasture, with a small proportion of arable land; and on it there are three habitations and two farm-steadings. The water is filtered, but no other special precautions against contamination are taken.

Dalry obtains its water supply from an impounding reservoir on Thirdpart Farm, $1 \frac{1}{2}$ miles N.W. of the town, with a gathering ground of about 350 acres, between 700 and 1099 feet elevation, the highest point being Braidland Hill. This area, of which 80 acres are owned by the Council, comprises 20 acres of arable land and 300 acres of hill pasture and moor, and has one habitation upon it.

Kilbirnie obtains its water supply from a storage reservoir on the Pundeavan burn at 890 feet elevation. The extent of the catchment area, on which there are no habitations or farmsteads, has not been ascertained. The Northern District Committee of the County of Ayr own the reservoir site, 14 acres.

The Irvine and District Water Board supply the towns of Irvine, Kilwinning, Stevenston, and Saltcoats. There are two catchment areas, situated to the west of Dalry, viz. : 
Caaf Reservoir area-

Over 1000 feet altitude

Acres. Acres.

Below ,, ,

379

2197

Munnoch Reservoir area-

All under 1000 feet altitude

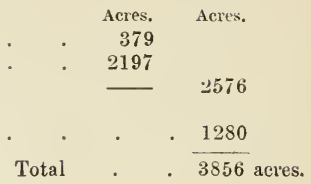

The total comprises 500 acres of arable land, 3315 acres of pasture, and 41 acres of old and new plantations. The Water Board own 161 acres at Caaf reservoir; but have only water rights over the remainder of the areas. All the land is at present farm-let. The sewage on the farms is led to intercepting drains and discharged below the reservoirs, except on two farms, where it is irrigated over grassland. The water is filtered at Greenhead. No planting operations have been contemplated.

Kilmarnock has two water catchment areas:

1. Northcraig area, 1500 acres, between 450 and 700 feet elevation, extending from Oldhall in the south-west to Blair on the north-east. It is partly arable, and partly pasture, with 18 farm-steadings. On two of the farms, nearest to the reservoirs, addle tanks and carts are provided.

2. Dunton area, 1300 acres, between 826 and 1009 feet elevation, all pasture and peaty. There is only one farmsteading; and it is doubtful if it drains within the area. The average annual rainfall is $42 \cdot 74$ inches.

No part of the areas is owned or controlled by the Corporation. There are no trees on either area. The water is passed through a sand and gravel filtration plant. There are five reservoirs, Northcraig, Gainford, Burnfoot, Dunton, and Loch Goin.

Ayr obtains its water supply, partly from springs at Milton and Grange, near Maybole, with two reservoirs at Carcluie; and partly from Lochs Finlas and Derclach. These two small lakes, about 17 miles S.S.E. of Ayr, and at 834 feet elevation, are situated in a hilly district entirely devoted to pasture. By the construction of an embankment about 12 feet high across the outlet, Loch Finlas was raised, 
and converted into an impounding reservoir containing $347,000,000$ gallons of water. The catchment area, 2680 acres in extent, is held by the Corporation as a freehold, and comprises:

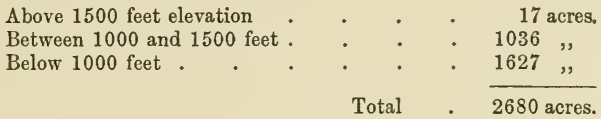

The area, which is uninhabited and of a peaty nature, is grazed by sheep, there being no arable land or plantations. The water from Loch Finlas, which is very soft and slightly brownish from a peaty stain, is conveyed to Knockjarder reservoir, where it is mixed with the Milton and Grange spring water, the mixture obtained being passed through filter beds. No scheme of planting the Loch Finlas eatchment area has been proposed. See description of Ayr water supply by John Young, C.E., in Proc. Inc. Assoc. Municipal and County Engineers, vol. 32, pp. 82-93 (1906).

Girvan obtains its water supply from Pinmacher Burn, 3 miles to the south-east of the town. The catchment area consists of 200 acres of hill pasture at 500 to 800 feet elevation. The Town Council own only the site of the reservoir.

Troon, Prestwick, and the Ayrshire Special Water District, which includes many mining villages, are supplied with water from Loch Bradan in the southern highlands of Ayrshire. Loch Bradan was raised a height of 8 feet by a dam built across the valley, thus making it and the adjoining Loch Lure one continuous sheet of water, 166 acres in extent and 986 feet above sea-level. There are five other small lakes on the watershed: Lochs Dhu, Breckbowie, Skelloch, Cornish, and Girvan Eye. The catchment area, 3650 acres in extent, is clean hill pasture, absolutely free from human habitation. The Troon Town Council own only the land covered by Lochs Bradan and Lure, which are fenced in. The Loch Bradan area adjoins the Loch 
Finlas area, belonging to Ayr; and for afforestation purposes both might be united in one scheme.

Stranraer obtains its water supply from the Dindinnie reservoir, with a gathering ground of 550 acres, between 150 and 160 feet elevation, none of which is owned by the town. The area, which has one farmstead on it, comprises 70 acres of arable land and 480 acres of hill pasture. The water is filtered, and contamination of the gathering ground is guarded against by piping and fencing.

Kirkcudbright obtains its water supply from High, Low, and Mid Boreland farms, which aggregate 334 acres, at 140 to 300 feet elevation, all owned by the Town Council. There are farm-steadings and habitations on the area; but as the supply comes from springs and not from surface water, the risk of pollution is not very great.

Dumfrles and Maxwelltown obtain their supply from Loch Rutton, in Kirkcudbrightshire, which has a catchment area of 3500 acres, between 320 and 600 feet elevation, consisting partly of arable land and partly of pasture. There are approximately 16 farm-steadings and 50 houses on the area, which has a population of 500 persons, but the greater number dwell in the village of Lochfoot, the sewage of which is drained clear of the lake. Certain agreements were entered into, about 4 years ago, with the proprietors and tenants of three farms near the loch, by which measures were taken to prevent the sewage finding its way into the loch. The other farms do not seem to have been dealt with. No part of the catchment area is owned by the Dumfries and Maxwelltown Water Commissioners. The average annual rainfall for 1907-1916 was 47.78 inches.

Annan obtains its water supply from an impounding reservoir at Purdomstown in Middlebie parish, with a gathering ground of 1350 acres, situated between 440 feet and 1000 feet elevation. It is mainly hill pasture, without any plantations or arable land. There are no 
steadings upon it, but there are two houses. Of the total area 16 acres are owned by the Corporation. I have no information as to what measures are taken against contamination of the water.

\section{Stirling and Lanark Counties}

Gathering grounds, 43,362 acres, supplying fifteen local authorities (Gorbals area supplying Glasgow and Carmunnock area supplying Upper District of Renfrew included). 10,290 acres owned by two local authorities.

Stirling obtains its water supply from the Touch catchment area, about 4 miles south-west of the town, 1250 acres in extent, of which 600 acres are below 1000 feet elevation and 650 acres between 1000 and 1500 feet. The area is wild rocky moorland and rough hill grazing, without arable land, peat, plantations, or habitations. The Waterworks Commissioners own only the sites of the reservoirs, $53 \frac{1}{2}$ acres, but have the right to take water in perpetuity subject to an annual payment. The three reservoirs are at 887,759 , and 707 feet elevation; a small settling pond is at 484 feet, and the filters are at 455 feet. The average annual rainfall for 30 years on the area is 44.43 inches, varying from 34.77 to 63.25 inches.

Kilsyth obtains its new water supply from the Corrie reservoir, about a mile north-west of the burgh, with a gathering ground of 190 acres, all hill pasture, between 852 and 1393 feet altitude. The Council own the site of the reservoir and some land around it, about $12 \frac{1}{4}$ acres fenced in. The catchment area, which has no habitations or farm-steadings, is grazed by sheep and a few cattle. The sheep drains are occasionally cleared out near the reservoir. The water is not filtered. The total annual rainfall in 1912 was 70.20 inches.

Denny and Dunipace Burgh obtains its water supply from Overton catchment area, 220 acres in extent, between 
639 and 1159 feet elevation. An adjoining catchment area of 190 acres could be taken in if desired, but it is not used at present. The Town Council have merely the right to impound the water, and own only $4 \frac{1}{2}$ acres of land adjoining one of the reservoirs. The gathering ground is under grazing, and there is little chance of its cultivation or of the water being polluted. It would certainly be of great advantage, I am informed, if the hill on which the reservoirs stand could be planted, but the Town Council have no rights in the land which would enable them to facilitate the planting thereof.

The Falkirk and Larbert Trust obtain their supply of domestic water from a catchment area on the Denny and Kilsyth Hills, 2150 acres in extent, and between 700 and 1480 feet elevation, all upland pasture under sheep and cattle grazing, with only one habitation at the lowest point, and, in consequence, no danger of contamination. The water is passed through sand filters. There is also a catchment area of 1145 acres for compensation water on the Touch Hills at 1170 to 1430 feet elevation, covered with heather and peat and under sheep grazing. The Trust have only water rights over these two catchment areas.

Bridge of Allan Water Company, a private Company, supplies the town with water from the Wharrie Burn and the Cox Burn, which are led into the Cox Burn reservoir, about a mile and a half from Bridge of Allan. The Company owns only the site of the reservoir, and has not supplied any details regarding the acreage or nature of the catchment area, which is situated in a well-wooded district.

Grangemouth obtains its water supply from a gathering ground of 2300 acres at the head of Bannock Burn in the Denny Hills, about 5 miles south-west of Stirling, and between 553 and 1442 feet elevation, reaching its highest point at Earl's Hill, and with a northerly exposure. The 
Town Council have only control over the water rights, and do not own the catchment area, which is under sheep grazing, there being practically no trees. There is one small farm-steading and a shepherd's hut on the area, but no special measures are taken to prevent contamination of the water, which is not filtered, as the risk from these two buildings is very slight. Mr. D. A. Donald, the engineer in charge, is convinced of the desirability of Corporations securing full ownership of water catchment areas.

The Eastern District Committee of the Stirling County Council obtain theil water supply from the Buckieburn reservoir in St. Ninian's parish, with a catchment area of 934 acres of hill pasture, partly peaty and partly loamy clay, at 800 to 1150 feet elevation. The gathering ground, which is without habitations, farm-steadings, or plantations, is not owned by the Committee. The water is filtered. The annual rainfall in the 10 years $1907-1916$ varied from 49.08 to $67 \cdot 11$ inches.

Lanarkshire Middle Ward District Waterworks supplies an area of 281 square miles, including 14 parishes, but excluding the burghs of Hamilton, Motherwell, Wishaw, Airdrie, and Coatbridge. There are three sources of supply: Glengavel reservoir, 8 miles south of Strathaven; Logan and Dunside reservoirs, 8 miles south-west of Lesmahagow on Logan Water; and the Camps area, $3 \frac{1}{2}$ miles E.N.E. of Crawford village. The Camps area, 6800 acres, of which about 4400 acres are between 1500 and 2141 feet elevation, 1200 acres between 1250 and 1500 feet, and 1200 acres between 980 and 1250 feet, is all owned by the County Council, who are now carrying out a scheme of afforestation, involving ultimately the planting of 2426 acres. See pp. 27-32 for full description.

The other catchment areas-Glengavel gathering ground, 3820 acres, between 839 and 1556 feet elevation, and the Logan and Dunside areas, 2200 acres, between 1018 and 1712 feet-are privately owned, but the County Council control the full water rights. It is not proposed now to 
afforest these areas, which are largely composed of peat, giving off at certain seasons water dark in colour and containing matter in suspension. Mr. W. A. P. Tait gave in Proc. Inst. Civil Engineers, vol. 159, pp. 329-341, Plate 11, fig. 1 (1903), an account of the Mid-Lanark water supply, with map showing its distribution and all the reservoirs in Lanarkshire.

Hamilton obtains its water supply from two catchment areas: (1) Kype reservoir area, 2140 acres of moorland at 936 to 1556 feet above sea-level, the latter elevation being that of Goodbush Hill, north of Muirkirk. The area is rough grazing for sheep, and some peat, without any arable land or farm-steadings. Forty-four acres are owned by the Corporation. The annual rainfall averages $47 \cdot 28$ inches. The water is passed through sand filters. (2) Wellbrae and Cadzow area, 1480 acres of arable land and pasture, at 601 to 766 feet altitude. On Cadzow there are 3 farm-steadings, and on Wellbrae 5 farm-steadings and 4 habitations, but all sewage is intercepted by fireclay pipes and run past the reservoir. Fifty-six acres are owned by the Town Council. There are 20 acres of Scots pine plantation, and the annual rainfall averages 34.66 inches. The water is passed through mechanical filters.

The Bathgate District Committee of the Linlithgowshire County Council obtain their water supply from the Forrestburn reservoir, south of Forrestfield Station, with a gathering ground in Lanarkshire of 1540 acres at 750 to 1000 feet altitude. This area consists of 1300 acres of hill pasture, 200 acres of moorland, 20 acres of arable land, and 20 acres of tree plantations. It is not owned by the County Council, who have only the water rights; and as it is free from farmsteadings and habitations, no special measures are taken to prevent contamination of the water.

Motherwell obtains its water supply from three catchment areas, as follows:

1. Culter reservoir, $25 \frac{1}{2}$ miles S.E. of Motherwell, has a 
gathering ground of 1963 acres in the steep stony hills at the sources of Culter Water and west of Culter Fell. The ground lies between 1150 and 2454 feet elevation, and is used for sheep grazing, there being apparently little or no risk of pollution.

2. Springfield reservoir, $3 \frac{1}{2}$ miles east of Carluke, has a catchment area of 1100 acres at 866 to 1029 feet elevation, mostly grazing. Part of the land, being under cultivation, is cut off by a bye-wash.

3. Coldstream reservoir, the water of which is not used for domestic purposes, has a catchment area of 650 acres, at 817 to 1009 feet altitude, all agricultural land.

The Corporation own no part of these areas, except the sites of the reservoirs. Part of the Culter gathering ground could probably be afforested in the same way as the Camps catchment area, which almost adjoins it.

Lanark obtains its water supply from an impounding reservoir on Tinto Hill in Carmichael parish, with a gathering ground of 790 acres, situated between 1000 and 2317 feet elevation, entirely hill pasture and moorland, except 8 acres of plantations, and free from habitations or farmsteadings. The Corporation own only the site of the reservoir and filters, about 12 acres, and no special precautions against contamination of the water seem to be necessary.

Wishaw obtains its water supply from the Elvanfoot and Gair reservoirs. The Elvanfoot catchment area-6890 acres, between 1000 and 2403 feet elevation-is in the Lowther Hills, comprising Burby Shank, Faugh and Laght Hills, with Riccart, Law Rig and Meikle Shag, which are drained by the Potrail Water and Potrennick and Pedden Burns. It is partly sheep grazing and partly grouse moors. Afforestation on similar lines to that on the Camps area may be possible. Gair catchment area, 395 acres, s.t 764 to 1083 feet altitude, is in the Benty Hillocks, west of Lamington, and is all under sheep grazing. Particulars of ownership of the two areas have not been obtainable. 
The Airdrie, Coatbridge, and District Water Trust obtain their water supply from two catchment areas, which are held as freehold-Rough Rigg, acquired in 1846, and Cowgill in 1893. The catchment area of the Rough Rigg reservoir, 2100 acres, at 687 to 900 feet elevation, lies to the east of Airdrie, near Clarkston, and consists of grazing and arable land. Cowgill reservoir has a gathering ground of 1390 acres, between 1000 and 2000 feet, east of Lamington in Clydesdale, all under grazing except 13 acres of plantations. No schemes for planting trees have been contemplated.

\section{Lothians, Peebles, Berwick, Selkirk, and Roxburgh Counties}

Gathering grounds, 30,382 acres, supplying thirteen local authorities. 6690 acres owned by three local authorities.

Edinburgh obtains its water supply from three localities : the Pentland Hills, the Moorfoot Hills, and the Talla area in Peeblesshire.

The water supply from the Pentland Hills is mainly from springs, none of the surface water being utilised except in the case of the Glencorse area. A description of these springs and of the various reservoirs which have been built on the north side of the Pentlands to provide compensation water, etc., is given by Mr. A. Leslie in Proc. Inst. Civil Engineers, vol. 74, pp. 91-127 (1883), and need not be repeated here, as there is no necessity on hygienic grounds to afforest the areas in which these reservoirs are situated. Mr. Leslie explains that "the configuration of the north side of the Pentlands would not permit of a surface water scheme being adopted for Edinburgh as the water is almost always coloured with peat, and in wet weather very much so." The Glencorse valley, on the south side of the Pentlands, the surface water of which is used, has a catchment area of 3825 acres, situated between 750 and 1750 feet elevation, comprising: 
Above 1500 feet elevation

Between 1250 and 1500 feet

Between 1000 and 1250 feet

Between 750 and 1000 feet

Reservoir

\begin{tabular}{|c|c|c|c|c|}
\hline . & & & \multicolumn{2}{|c|}{25 acres. } \\
\hline - & & * & 231 & , \\
\hline - & & . & 1240 & ", \\
\hline • & & . & 2258 & ", \\
\hline - & . & . & 71 & " \\
\hline & & & 3825 & cre \\
\hline
\end{tabular}

There are two reservoirs, Glencorse and Loganlea. According to Mr. Leslie, "the water draining into the Glencorse reservoir is naturally free from peat, the watershed consisting of high hills covered with short grass. However, it becomes more mossy towards the upper reaches, so that the water impounded in the Loganlea reservoir is at times darkly coloured. The whole catchment area is under hill grazing with the exception of 45 acres. The average annual rainfall is $37 \cdot 61$ inches. The Glencorse gathering ground would seem to be suitable for afforestation, but it is not owned by the Edinburgh Corporation. The Water Trustees only exercise over the area the general powers to prevent fouling of the water that are conferred by the Waterworks Clauses Act of 1847."

The Moorfoot Waterworks consist of three areas: Gladhouse reservoir, with a catchment area of 6131 acres, Tweedale Burn, 1337 acres, and Portmore reservoir with 610 acres, or 8078 acres in all. There are two compensation reservoirs, Roseberry and Edgelaw, the former on the South Esk and the latter on its tributary, the Fullerton Burn. The Moorfoot areas are not owned by the Edinburgh Corporation, and no scheme for their afforestation has been mooted.

The Talla catchment area comprises 6180 acres, of which 5760 acres have been purchased by the Edinburgh Corporation. Most of it is at a high elevation, as shown in the following table:

\begin{tabular}{|c|c|c|c|c|c|c|c|c|c|}
\hline Between & 1500 & and 2526 & feet ele & vat & ion & & & 4520 & acres \\
\hline$"$ & 1250 & " 1500 & ", & , , & & & . & 510 & ", \\
\hline$"$ & 1000 & 1250 & $"$ & ", & . & & • & 720 & $"$ \\
\hline ", & 950 & 1000 & ", & , & • & & • & 130 & , \\
\hline Reservc & at 9 & 0 feet ele & vation & & . & 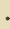 & . & 300 & , \\
\hline
\end{tabular}




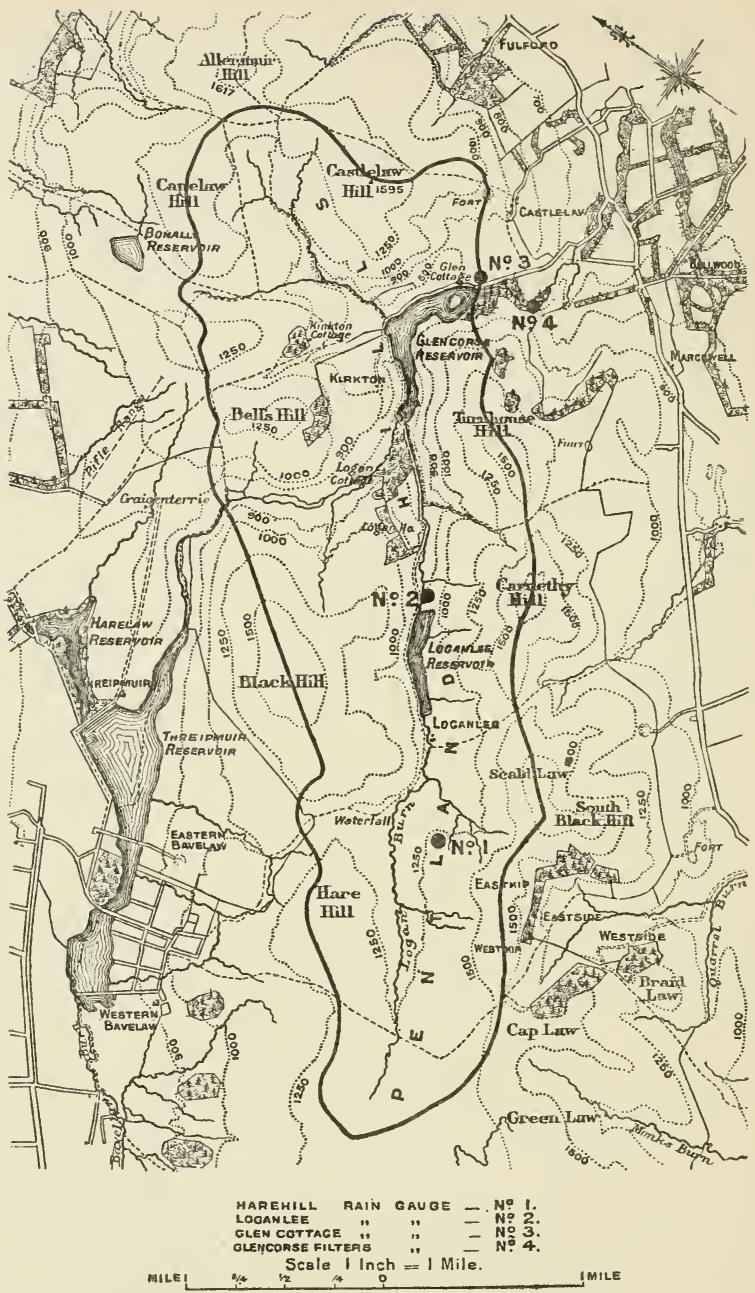

Fia. 43.-Edinburgh. Glencorse Burn Catchment Area. (From Proc. Inst, Civil Enginsers, vol. 194.) 
There is no arable land on the area, which is mostly hill grazing. In 1912 there were 27 acres of young plantations, but no mature woods. Mr. W. A. P. Tait, who published in Proe. Inst. Civil Engineers, vol. 167, pp. 102-152 (1907), an account of the Talla water supply with map and diagrams, states that "practically the whole gathering ground, which is mainly hill pasture, with about 440 acres of peat, was acquired at a cost of $£ 36,000$ by the Trustees, who are thus enabled to preserve the purity of the water draining into the reservoir. The Trustees derive a rent of a little more than $£ 300$ per annum for the hill pasture above the level of the reservoir." The average annual rainfall on the area varies from 47.66 to 73.92 inches at the different stations.

Mr. Stebbing of the Edinburgh University, who drew up a planting scheme in 1912, is of opinion that 600 acres of the whole area are available for planting, the upper limit extending on exposed hillsides to the 1250 feet contour line, and in sheltered glens to about 1400 feet. Planting was begun in 1914 (Fig. 16), the plan providing for 10 acres annually for the first three years, and 50 acres yearly afterwards. As none of the plantable land is situated at a lower elevation than 950 feet, the number of species available is very limited. Scots pine is considered to be inadvisable. Larch is recommended for the lower elevations, and Sitka spruce for the higher ground above the larch up to 1250 feet contour line; while Douglas fir could be planted wherever there was good soil in sheltered situations in the glens. In moist localities common spruce would be used in place of the other species.

The Development Commissioners sanctioned in 19131914 a loan of $£ 150$ for the experimental planting of about 30 acres on the Talla catchment area. Of this only $£ 75$ has apparently been advanced by the Treasury. The larger scheme by which the Edinburgh and District Water Trust were to be provided with funds for planting at least 600 acres appears to be in abeyance.

W. C. Reid, in Proc. Inst. Civil Engineers, vol. 194, 


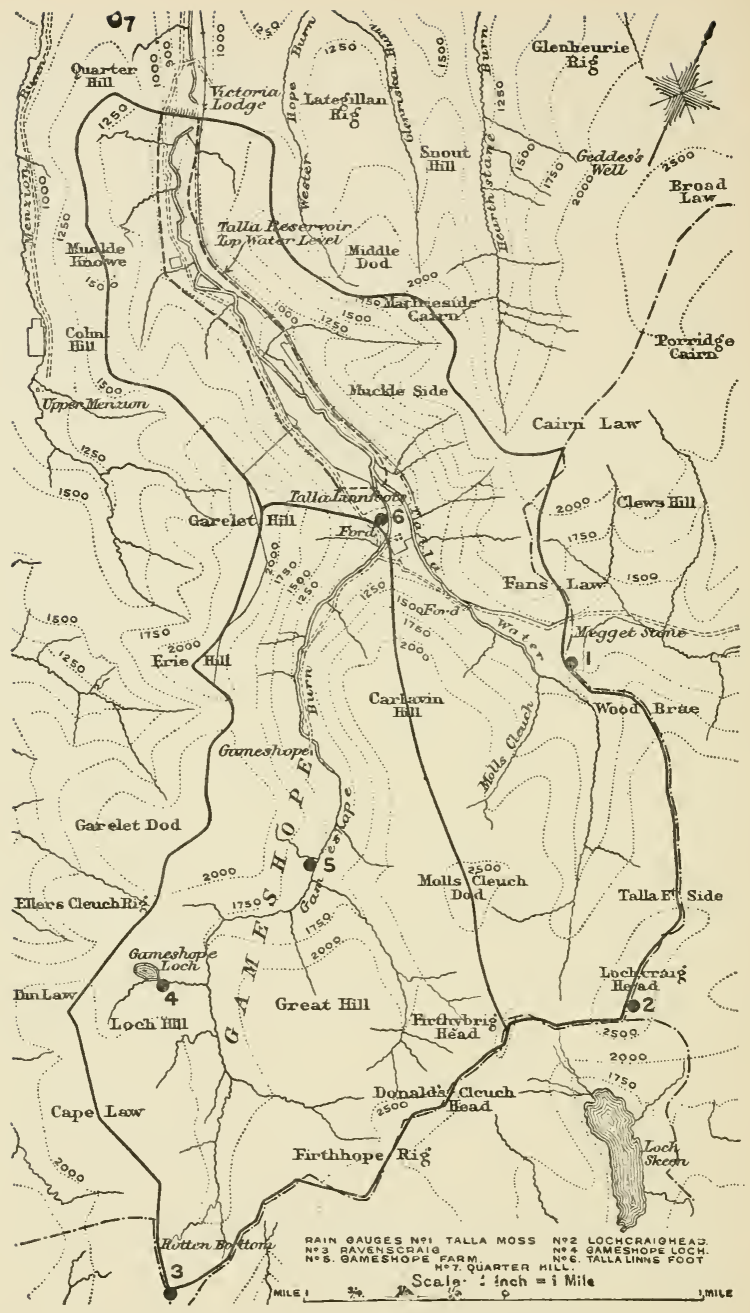

FIG, 44.-Edinburgh. Talla Water Catchment Area. (From Proc. Inst. Civil Engineers, vol. 194.) 
pp. 4-9 (1914), discusses the rainfall and gives maps, now reproduced, of the Glencorse and Talla areas. See also B. H. Blyth and W. A. Tait in Proc. R. Soc. Edinburgh, xxv. 616, with map (1905).

Loanhead obtains its water supply from Hillend reservoir, which has a gathering ground of 50 acres, at 1200 feet elevation. The Town Council have also a good spring on Pentland Mains.

Bo'ness obtains its water supply from two catchment areas situated about three miles south of the town. Lochcote reservoir has a gathering ground of 600 acres, between 600 and 800 feet elevation, in the valley of the Brunton and Kipps burns (on the west side of the Kipps Hill) in Torphichen Parish, Linlithgowshire. Carribber reservoir has a gathering ground of 280 acres, between 450 and 600 feet elevation, on the north-west side of Bowden Hill. Both areas are clean pasture land, without trees, the only habitation being Lochcote House, the drainage of which is intercepted and discharged into the stream below the reservoir embankment. The Town Council own the site of the Lochcote reservoir, about 54 acres; and hold on lease for 99 years the land at Carribber. The annual rainfall averages, over a period of 15 years, about 34 inches. The water supply is filtered.

The Linlithgow District Committee obtain their water supply from the Morton reservoir, which has a gathering ground of 500 acres of hill pasture, at 700 to 1500 feet elevation, situated between Morton and Corston farms, on the north side of the Pentland Hills. There are no farmsteadings or houses on the area, which is not owned by the County Council. There were 16 acres of Scots pine in 1912. The average annual rainfall is 38.11 inches.

Whitburn obtains its water supply from a gathering ground of 88 acres, between 600 and 620 feet elevation, comprising 40 acres of arable land and 48 acres of hill pasture. The water is not filtered. The statement in 
Journ. Board of Agriculture, xi. 472 (1904), that the Burgh owns 100 acres of catchment area, I am informed, is incorrect.

The Central District of the County of Linlithgow are constructing on the Riccarton Burn, two miles south of Linlithgow, the Bescraigs reservoir, with a gathering ground of 560 acres. The Corporation own none of the land, which consists of 160 acres of arable, 100 acres of pasture, occasionally ploughed, 250 acres of permanent pasture, and 50 acres of plantations. There is a farm-steading, but a drain has been constructed to take the sewage past the reservoir. In the opinion of the engineers, "it would be very advantageous from the waterworks point of view if this area were afforested, in view of the fact that so large a portion is arable land." It ranges in elevation from 500 to 900 feet above sea-level.

The Prestonpans Combination Water Trust obtain their supply from the Yester catchment area, 500 acres of heather moor, at 950 to 1753 feet altitude on the north side of the Lammermuir Hills. The Trust do not own the area, which is all above the agricultural zone; but have some control over it given by various Acts of Parliament. There is no complaint about contamination of the water. There are two reservoirs.

North Berwick obtains its water supply from the Donolly reservoir, west of Garvald, with a catchment area of 1070 acres, at 700 to 1306 feet elevation; and from the Thorter reservoir, south-east of Garvald, with a catchment area of 900 acres, between 810 and 1400 feet elevation. The gathering grounds, which are on the northern edge of the Lammermuir Hills, consist of hill pasture, without any population, there being only one shepherd's hut, which is on the Donolly area. A small piece of cultivated ground near one of the reservoirs does not drain into it. No special precautions, except filtration of the water, have been considered necessary by the Town Council, who own 
only the sites of the reservoirs, for which an annual payment is made. The proprietors of the land have recently done a little planting of trees. The annual rainfall averages $31 \cdot 30$ inches for Thorter and 34.40 inches for Donolly. The Donolly reservoir obtains its supply, not from the Donolly stream, which proved unsuitable, but from the adjacent Papana stream.

Duns obtains its water supply from a reservoir on Hardens Hill, with a gathering ground of 361 acres, between 557 and 1166 feet elevation. The area, only 4 acres of which are owned by the Corporation, is without habitations, and comprises 65 acres of arable land, 240 acres of hill pasture, and 56 acres of plantations. The water is filtered.

Lauder is reported in Journ. Board of Agriculture, xi. 472 (1904), to own a catchment area of 650 acres, hill pasture, at 900 feet elevation. Information about this water supply has not been obtainable.

Galashiels obtains its water supply from the Caddon Water valley, with a catchment area of 4160 acres, at 800 to 2160 feet elevation, mostly moorland and grazed by a few sheep. The Town Council do not own the area, but have the water rights.

Hawick water supply is obtained from hill pasture lands to the south-west of the town. The main supply is from the Dod Burn, about 6 miles off, with a catchment area of 1280 acres at 700 to 1500 feet elevation, and the water is stored in Acre Knowe reservoir, at 610 feet elevation. Another supply is taken direct from the Allan Water at Lodburn, about 5 miles away. There is a population of 20 persons on the catchment areas, which are not owned by the Town Council. The land is hill pasture grazed by sheep, except 20 acres arable. None of the water is filtered, and complaints are sometimes made in summer about its fishy taste. This is due to a weed which grows in the Acre Knowe reservoir. The water 
supply, however, is excellent and abundant, and rushes as a clear stream along the channels of the streets, washing them night and day.

Kelso obtains its water supply from a reservoir in the Cheviot Hills, with a gathering ground of 1300 acres, between 763 and 1842 feet elevation, practically all hill pasture and moor, and without habitations or farm-steadings. The town owns only the site of the reservoir, which is surrounded by an unclimbable fence. The water is passed through screens.

\section{Clackmannan, Kinross, and Fife Counties}

Gathering grounds, 27,772 acres, supplying eleven local authorities (Loch Glow and Cullaloe areas supplying Dunfermline District included). 1884 acres owned by three local authorities.

Alloa obtains its water supply from the Gartmorn reservoir, which has a direct gathering ground of 1148 acres; but an additional supply is obtained by an aqueduct from the upper part of the Black Devon River, with a catchment area of 11,125 acres. The whole area lies approximately between the 200 and 1000 feet contours, and consists of arable, pasture, and woodlands, with a small proportion (about $\frac{1}{15}$ ) of moorland. There are 51 farmsteadings on the area, none of which is owned by the Town Council, except the sites of the reservoir and the intake aqueduct. No special precautions are taken against contamination of the water, which is passed through sand filters.

Lochgelly obtains its water supply from two reservoirs, Upper and Lower Lochornie, with a gathering ground of 611 acres, situated between 684 and 965 feet elevation, and comprising 4 acres of arable land, 559 acres of hill pasture and moorland, and 48 acres of plantations, which are now partly cut down. The Corporation own only the sites of the reservoirs, about 15 acres, but have powers 


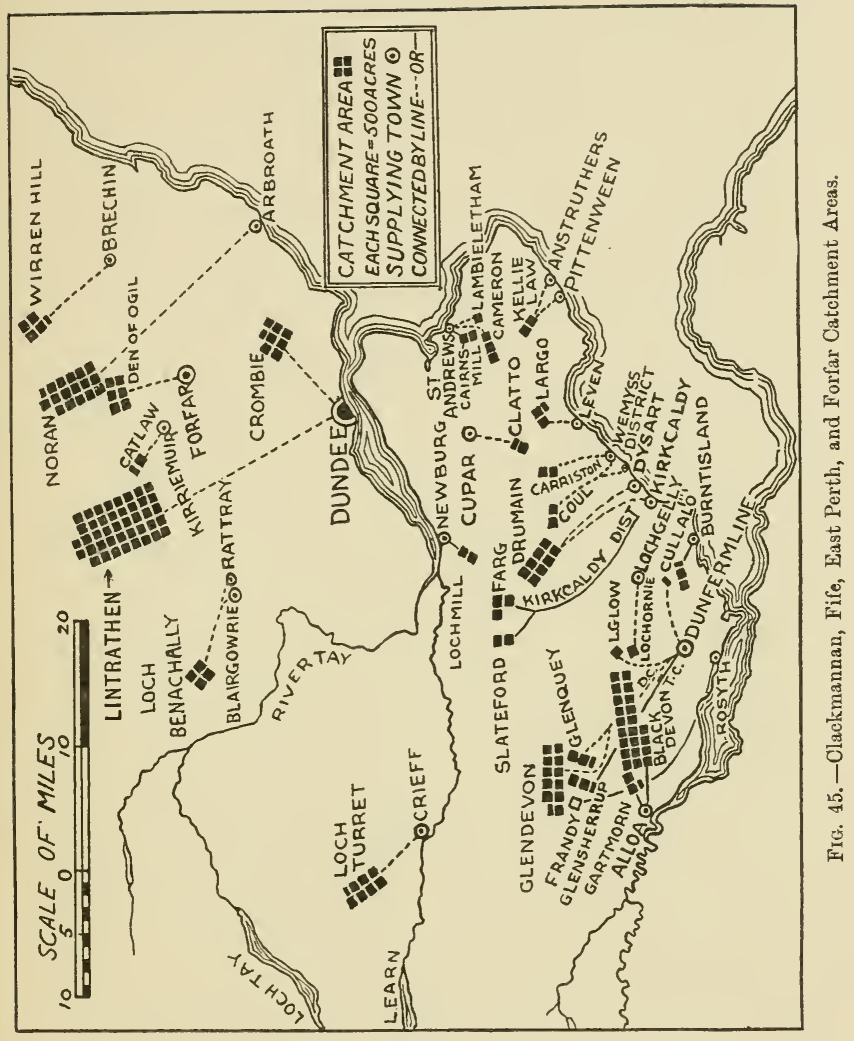


to take an additional supply from Craigencat Burn, with 154 acres of catchment area. The gathering ground has one farm and one shepherd's house upon it, but no special precautions are taken except that the water is filtered. Mr. A. Lumsden, the Burgh Surveyor, considers the greater part of the two gathering grounds to be suitable for afforestation.

Burntisland obtains its water supply from the Cullaloe reservoir, with a catchment area in the valley of Dour Burn, 1200 acres, between 300 and 500 feet elevation. The gathering ground comprises 1000 acres of arable land and 200 acres of woodland, none of which is owned by the Town Council, except the site of the reservoir and a margin around it, varying from the width of a few feet to about 50 yards. The reservoir is now divided by an embankment into two distinct parts. The south bay, receiving pure water from the upper reaches of the Dour Burn, supplies the town; while the north bay, fed by somewhat impure water from the Cullaloe Burn, supplies compensation water to the lower riparian owners. The Council have no control over the gathering ground, which is reported to have a population of 150 persons; but the sewage from three farms is led clear of the domestic supply reservoir and the water is filtered. The average annual rainfall taken over a period of 23 years is 31.94 inches.

Kirkcaldy and Dysart Commissioners obtain their water from Drumain, Harperlees, and Holl supply reservoirs; and in addition there are the Ballo and Arnot compensation reservoirs. The total catchment area is 3922 acres, ranging in elevation from 645 to 1712 feet, namely, to the top of West Lomond Hill. Of the whole area, the Commissioners own 1654 acres, all hill pasture and moor, except 20 acres of arable land and 55 acres of plantations. The remaining 2268 acres are moor and hill pasture, except 66 acres of plantations. There are 20 persons resident in six dwelling-houses on the gathering ground. Practically all the sewage is carried past the reservoirs, or, alternatively, 
passes into reservoirs which are not used for domestic purposes. The water is partly filtered by sand beds and partly by open mechanical filter beds. The plantations on the catchment area show that it is suitable for a considerable scheme of afforestation.

Wemyss and District Water Trust obtain their supply from two gathering grounds: Coul reservoir, with a catchment area of 1000 acres, between 493 and 1467 feet elevation; and Carriston reservoir, with a catchment area of 1100 acres, between 311 and 750 feet elevation. The Trustees own 26 acres of the Coul area, and 26 acres of the Carriston area. The Coul gathering ground is mainly pasture, but has four farmhouses, with five farm-steadings and byres, a keeper's house, and a mill upon it. The Carriston area is largely arable land, with some plantations upon it, which are now being cut down. It has a considerable population, with 21 houses of various kinds, 2 shops, a sawmill, and 10 farmsteads, byres, etc. Some of the farm-steadings and byres are fitted with sewage tanks and pumps. The water is filtered.

Cupar (Fife) obtains its water supply from Clatto reservoir, with a gathering ground of 820 acres, at 550 to 650 feet elevation, described as nearly all hill pasture without any plantations. There is one farm with buildings on the area, and a septic tank is used for the sewage. Part of the land of four other farms drains into the gathering ground. The Town Council own only 8 acres. The annual rainfall was, in 1911, 33.44 inches, and in 1912, 21.78 inches. The water is passed through sand filters.

Leven obtains its water supply from Leven reservoir, with a gathering ground of 1250 acres in Largo and Scounie parishes, at 250 to 300 feet elevation, all arable land and pasture. The Town Council own only the water rights. The sewage from the houses and farms on the area is intercepted by spigot and faucet pipes, and is carried past the reservoir. 
The Pittenweem and the Anstruthers Joint Waterworks obtain their water supply from a catchment area of 1070 acres, situated on Kellie Law, Carnbee Law, and the ridge of lower ground eastward, between 177 and 500 feet elevation. The Committee own only the sites of the reservoirs on the gathering ground, which is practically treeless and mainly arable. It includes Gordonshall farm and Carnbee village and farm, the sewage of which is carried off in a pipe system and falls into the main burn below the waterworks.

St. Andrews obtains its water supply from three catchment areas, which are situated in Cameron parish, at no great elevation above sea-level. The Burgh Surveyor has supplied me with the following particulars:

\begin{tabular}{|lr|r|c|c|c|}
\hline \multicolumn{1}{|c|}{ Catchment Area. } & Acres. & $\begin{array}{c}\text { Altitude in } \\
\text { feet. }\end{array}$ & $\begin{array}{c}\text { Farm- } \\
\text { steadings. }\end{array}$ & Habitations. \\
\cline { 1 - 1 } Cairnsmill . &. & 906 & $250-450$ & 5 & 19 \\
Lambieletham . &. & 550 & $350-500$ & 3 & 14 \\
Cameron . &. & 1450 & $470-650$ & 5 & 19 \\
\hline
\end{tabular}

The total area, 2906 acres, which is partly arable and partly under pasture, has thus no less than 13 farm-steadings and 52 habitations upon it. The means taken to prevent pollution of the water are: fencing of the streams and reservoirs; providing water-troughs for stock; separate drainage for farms into septic tanks and cesspools ; sedimentation in the reservoirs, and careful filtration. The Council have merely water rights over the greater part of the area, the only portion owned being 180 acres at Cameron, 100 acres of which are under water, the remaining 80 acres being almost fully planted with trees. See W. Watson, in Proc. Inc. Assoc. Municipal and County Engineers, vol. 33, pp. 239-242 (1907).

Newburgh obtains its water supply from Loch Mill, with a gathering ground of 900 acres, at about 700 feet elevation, without habitations or farmsteads, and comprising 500 
acres of arable land, 300 acres of hill pasture and moor, and 100 acres of plantations. Of the total area, the town owns 150 acres. The water is filtered.

\section{Perth (East) and Forfar Counties}

Gathering grounds, 50,935 acres, supplying ten local authorities. 1500 acres owned by one local authority.

The Kirkcaldy District of the County of Fife, in which Kirkealdy, Dysart, and Kinghorn Burghs are not included, will be supplied with water from two gathering grounds in the Ochil Hills in Perthshire. The river Farg catchment area, on which a reservoir is being built, contains 1437 acres, at 550 to 1000 feet elevation. The Slateford Burn catchmeut area adjoins the last, and comprises 1166 acres, at 650 to 1200 feet altitude. The water will be taken from the Slateford Burn to the Farg reservoir by a 24-inch pipe. None of the land is owned by the Council except about 100 acres required for the site of the reservoir. On the Farg area there are 200 to 300 acres of arable land, the rest being rough pasture. The Council intend to divert the sewage from the four existing farm-steadings; but measures for preventing contamination of the reservoir are troublesome on account of the divided ownership, as there are twelve proprietors on the Farg area. There is little arable land on the Slateford Burn area, most of it being rough pasture. The engineers are of opinion that the afforestation of the Farg gathering ground would be desirable, in order to secure the purity of the water supply; but it is very doubtful if the County Council could face the expense of acquiring the whole area for this purpose. Meanwhile. compensation is liable to be paid to proprietors who may be injuriously affected by any restrictions imposed under the Water Act for the prevention of pollution. See W. C. Reid, in Proc. Inst. Civil Engineers, vol. 194, p. 6, Fig. 3 (1914), for rainfall and map, here reproduced, of the Slateford and Farg areas. 


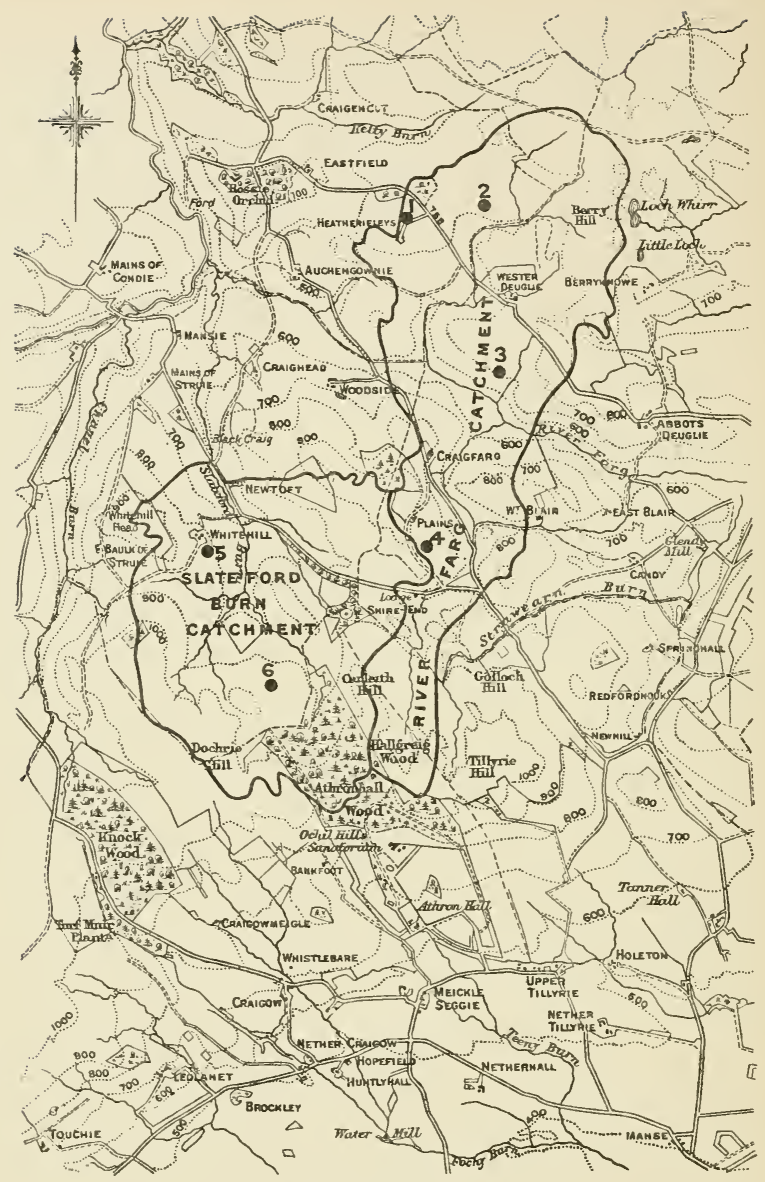

RAIN GAUGES

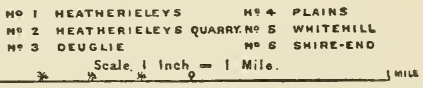

FIG. 46.-Kirkealdy District. Slateford Burn and River Farg Catchment Areas.

(From Proc. Inst. Civil Engineers, vol. 194.) 
Dunfermline District is supplied with water from 4 catchment areas, the two largest of which, Glendevon, 5780 acres, and Glenquey, 1299 acres, are in the Ochil Hills. These two areas are divided according to elevation as follows:

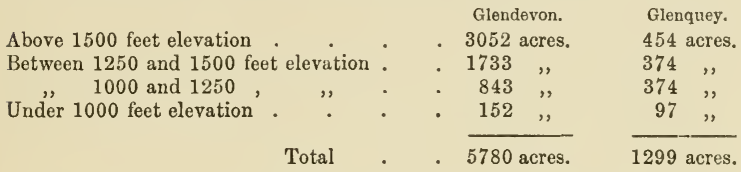

These areas are mainly rough grazing for sheep, with a little peat, and no arable laud. The Dunfermline District Committee of the Fife County Council own none of the land except the sites of the reservoirs. No special precautions are taken against contamination from dead sheep or from disease among the sheep, the risk being considered negligible. The water is passed on to the consumer in its natural state, without being filtered. The Dunfermline District Committee supply the whole of the water required for Admiralty purposes at Rosyth. The Admiralty are said to be part-owners of the works at Glenquey and of the new reservoir which is being built at Frandy in Glendevon.

Loch Glow reservoir has a catchment area of 650 acres, in the counties of Fife and Kinross, between 890 and 1103 feet elevation. Cullaloe gathering ground, 70 acres, lies between 500 and 700 feet altitude. Both the Loch Glow and Cullaloe areas are under sheep grazing and uninhabited. The water from them is passed through sand filters.

Dunfermline Town Council obtains its water supply in part from Glensherrup, in the Ochil Hills, with a catchment area of 1300 acres, between 935 and 2004 feet elevation. The gathering ground, of which 40 acres are owned by the town, is entirely hill pasture and moor, without any plantations, and free from habitations and farmsteads. "It has never been found necessary, in all the 35 years the works have been in operation, to take any precautions against contamination." There is a secondary supply at Craigluscar, 
three miles from Dunfermline, with a catchment area of 360 acres, situated between 300 and 600 feet elevation. Fully a half of this is arable land. A further but very small supply is taken from shallow ground springs at Glassiebarns.

Crieff obtains its water supply in part from Loch Turret, which has a catchment area of 3855 acres, between 1127 and 3048 feet elevation, none of which is owned by the town. The whole area, except 165 acres covered by the loch, is hill pasture, and has two shepherds' cottages and one shooting lodge upon it.

The Blairgowrie, Rattray, and District Water Board obtain their supply from Loch Benachally. The catchment area, 1920 acres, between 1000 and 1622 feet elevation, is not owned by the Board, who control only the water rights. As there are no farm-steadings or habitations on the area, which is devoted to sheep grazing and grouse shooting, no measures are considered necessary against pollution of the water, which is passed through fine screens on leaving the loch, and through sand filters before reaching the storage tanks at Blairgowrie.

Arbroath obtains its water supply direct from the river Noran at Glenogil, Forfarshire. The catchment area above the compensation reservoir is 4700 acres, and above the intake for use 3600 acres, all moorland, between 700 and 900 feet altitude, of which three-fourths are covered with larch and Scots pine plantations. There is only one habitation, a shepherd's hut, the drainage from which flows into another valley. The Town Council own merely the site of the reservoir and intake works, $30 \frac{1}{2}$ acres, purchased for $£ 3665$. The water comes from pure mountain springs, and is passed through copper wire-woven screens, but is not otherwise filtered. The annual rainfall averages 35 inches.

Kirriemuir obtains its water supply from a catchment area of 820 acres, at 950 to 2197 feet altitude, on the 
eastern side of Cat Law, in Kingoldrum parish, Forfarshire. The water, which is not filtered, comes from springs in the side of the hill, and there is no impounding reservoir. The area is grazed by sheep, and is uninhabited, treeless, rocky ground, mostly covered with heather. It is not owned by the Town Council, who have the usual sanitary powers conferred by common law and statute. The annual rainfall, varying from 27 to 50 inches, averages 35.33 inches.

Brechin obtains its water supply from a catchment area of 2200 acres, between 600 and 2000 feet altitude, on Wirren Hill, in the Grampians, all heather-clad, under sheep grazing, and without dwellings of any kind. There are no trees on the area, which is privately owned, the Town Council having no control and only the right to the water and the pipe track, which was given free by the owner. There is no storage reservoir, and the water is not filtered; but no trouble as regards contamination bas arisen since the supply was introduced over 43 years ago.

Forfar obtains its water-supply from the Den of Ogil reservoir, in Tannadice parish, with a gathering ground of 2977 acres, lying between 600 and 1615 feet elevation, the highest point being St. Arnolds. The Corporation own 33 acres. The gathering ground comprises 2677 acres of hill pasture and plantations, and 300 acres of arable land, on which there are 8 habitations and farm-steadings. The water is screened and filtered, but no other measures are taken against containination.

Dundee obtains its water supply from two catchment areas: (1) The gathering ground feeding the Crombie, Monikie, and Brax reservoirs comprises 3643 acres, all at no great elevation, the highest point being under 700 feet. The Water Commissioners, in order to preserve the water from contamination, have taken on a lease of 99 years 500 acres of arable land on the Crombie area. This land, laid down in grass, reverts to moorland in a few years, and could be utilised more profitably if planted with a timber 
crop like larch, that would come to maturity in 50 or 60 years. (2) The Lintrathen area comprises nearly 21,000 acres at different elevations, as follows:

\begin{tabular}{|c|c|c|c|c|c|c|}
\hline & \multicolumn{5}{|c|}{ Above 1500 feet elevation . } \\
\hline \multicolumn{2}{|c|}{ Between 1250 and 1500 feet. } & • & - & . & 4,700 & ", \\
\hline \multirow{2}{*}{ Below 1000 feet } & 1250 feet. & • & - & • & 3,738 & $"$ \\
\hline & . $\quad$. & . & - & - & 8,700 & " \\
\hline
\end{tabular}

It is largely composed of heather and old pasture land of little value. About 1000 acres, which include the two arable farms that formerly existed on the area, have been purchased by the Corporation. Of this, about 200 acres have been planted with larch, spruce, Scots pine, and Douglas fir; while the rest is either let for sheep grazing or is laid down in grass. The abolition of the arable land ensures to a considerable extent the purity of the water drawn from the Lintrathen reservoir, which is not filtered; but in the opinion of Mr. Geo. Baxter, the engineer in charge, a larger measure of afforestation would be desirable. See p. 82, and Trans. Roy. Scot. Arbor. Soc. xxiv. 191 (1911).

\section{Inverness, Ross, and Aberdeen Counties}

Gathering grounds, 6843 acres, supplying seven local authorities (acreage of Peterhead gathering ground unknown and not included). 828 acres owned by three local authorities.

Inverness obtains its water supply from Loch Ashie, which has a catchment area of 1335 acres at 610 to 700 feet elevation. The gathering ground, over which the Corporation have no control, consists of moorland and hill pasture, one-third of it being formerly covered with plantations, which were cut down about 5 years ago. There are now no habitations or farm-steadings on the area. The Corporation took over as tenants the solitary croft that existed and levelled the buildings, the croft being now only used for sheep grazing. The water is passed through gravel and copper screens. G. West, in his account of 
Loch Ashie in Proc. Roy. Soc. Edin. vol. 25, pt. 2, p. 1009 , Fig. 73 (1906), says that the country on the east side is bleak, dreary moor, but on the west side the shores were then clothed with coniferous forest.

Kingussie is reported in Journ. Board of Agriciulture, xi. 472 (1904), to own a catchment area of 300 acres, hill pasture, at 1500 feet elevation. Information about this water supply has not been obtainable.

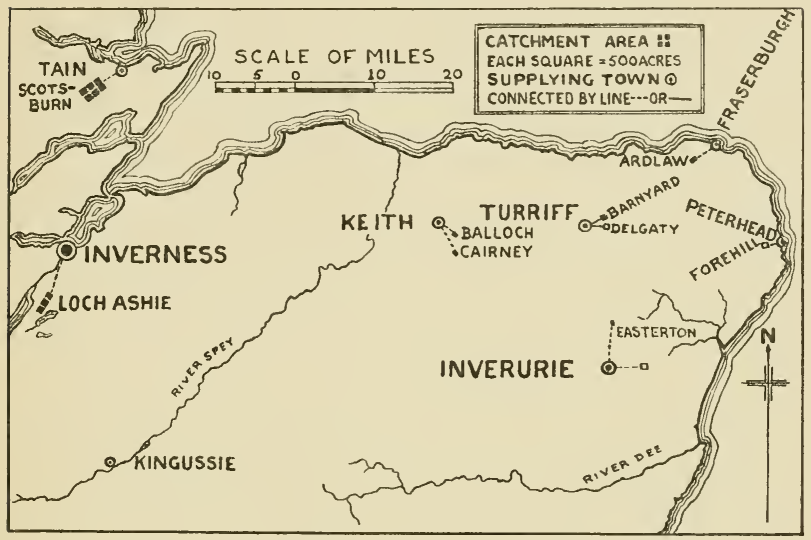

Fig. 47.-Inverness, Ross, and Aberdeen Catchment Areas.

Tain obtains its water supply from a gathering ground of 3000 acres, between 400 and 800 feet elevation, in the Glen of Scotsburn and Hill of Tain. There is one house on the area, of which 210 acres are owned by the Burgh. The water is not filtered, and no precautions against contamination of the gathering ground are considered necessary.

Fraserburgh has two catchment areas. The Ardlaw area, 280 acres at 100 to 150 feet elevation, collects underground water from a gravelly subsoil at a depth of 
16 to 25 feet. The water from the Fedderate gathering ground, which is 760 acres in extent, at 250 to 400 feet elevation, is treated by mechanical filters. The Town Council control the water rights, but do not own the areas, which are partly arable and partly pasture land.

Turriff obtains its water supply from the Barnyard Estate, of 318 acres, purchased by the Burgh in 1903 for $£ 6000$, all arable land, except 6 acres of plantations, and situated between 400 and 600 feet elevation. About 100 acres, as well as the main buildings, are below the reservoir, there being only a small house and steading above it. The collecting drains are 10 feet or more below the level of the ground; and the water is naturally filtered by gravel before reaching the drains. No surface water is taken. The Burgh has an emergency supply from a collecting reservoir on Delgaty Estate, but it is only used for flushing drains, except in rare cases of severe dronght. The gathering ground here is about 100 acres in extent, and is situated at less than 350 feet above sea-level.

Keith obtains its water supply from gathering grounds, which are not owned by the Town Council, at Balloch Hill and Cairney, 350 acres in extent, between 743 and 783 feet elevation, all hill pasture except 50 acres of arable land. The water is entirely derived from springs. On Balloch Hill area there are no houses or farms, and the water is passed through filtering screens. On Cairney area there are several farms and crofts, and the water is passed through gravel filter beds.

Peterhead obtains its water supply from three impounding reservoirs at Forehill, with a total capacity of $16,000,000$ gallons. The gathering grounds, of which the Town Council only own about 8 acres, are mostly arable land, with houses and farm-steadings, and are situated between 130 and 200 feet elevation. The water is collected in pipes from streams on the gathering ground, and is passed through sand filter beds. 


\section{WATER CATCHMENT AREAS IN SCOTLAND 285}

Inverurie obtains its water supply from deep springs in Baikie Howe, a valley about 8 miles distant. On the gathering ground, 500 acres of arable land, between 524 and 800 feet elevation, there are four small farms or crofts with steadings, the sanitary arrangements of which are inspected from time to time. Inspection chambers are provided at each spring, and the water is passed through screens and sand filters. The Burgh owns the farm of Mill of Eastertown, 202 acres in extent, of which about 30 acres are within the water catchment area. The water from Baikie Howe is distributed from Bransbutt reservoir. The old supply of the Burgh, also from deep springs, is collected in the Hillhead reservoir, which is used now in reserve. 


\section{CHAPTER XII}

\section{WATER CATCHMENT AREAS IN IRELAND}

IN Ireland, as in the sister countries, the water supplies of cities and towns are varied in origin. Some communities obtain their water directly from the large rivers on which they are situated, as Cork from the river Lee, and Limerick from the Shannon. Many smaller towns are still dependent upon local pumps and wells, or upon springs. In this chapter notice is taken only of the local authorities who have gathering grounds, as such areas might in most cases be afforested with advantage to the purity of the water supply and to the health of the population. No official description of the water supplies of Irish towns has been published; and the pamphlet on this subject by Sir Charles A. Cameron, published in 1885 (Fannin \& Co., Dublin), is out of date. In the following pages information, mostly furnished by town surveyors, is given concerning the gathering grounds of 57 cities and towns; but the acreage of ten catchment areas could not be ascertained. In the cases of ten towns, those marked with an asterisk, no official details have been obtainable, though application was made. The information cannot, then, clain to be exhaustive; nevertheless it is of considerable interest. Summarised, it shows that 47 cities and towns obtain their water supplies from 93,835 acres of gathering grounds; and if the returns were complete, the total would considerably exceed 100,000 acres. Municipal ownership of such lands is very limited in Ireland, 
the amount disclosed being 15,282 acres, owned by nine local authorities. Only three of these own a considerable proportion of their gathering grounds, namely, Belfast, which owns 13,746 acres; Portadown and Banbridge Joint Waterworks Board, which owns 943 acres; and Dublin, which owns 348 acres in addition to 712 acres of reservoir sites. The portions of their catchment areas owned by Rathmines, Drogheda, Lisburn, Holywood, and Waterford are very small. Scarcely any afforestation has been attempted, the only instances of municipal effort in this direction being 50 acres of old and 5 acres of new plantations on the Vartry area, belonging to the Dublin Corporation, and 50 acres of plantations made since 1900 by the Urban District Council of Rathmines on their catchment area at Glennasmol. The afforestation of the gathering grounds of Ireland cannot be effected until the areas are compulsorily acquired by the Urban District Councils and other local authorities concerned.

\section{ULSTER}

Gathering grounds, 41,253 acres, supplying twenty-one local authorities and one private owner (acreage of Letterkenny, Keady, and Ballymoney gathering grounds unknown and not included). 14,752 acres owned by four local authorities.

Belfast obtains its water supply from three catchment areas, as follows:

The Woodburn area, 3 to 4 miles north-west of Carrickfergus, and between 300 to 1000 feet elevation, contains 6937 acres, of which 3657 acres, formerly farm lands, were acquired by the Water Commissioners to prevent pollution, and were cleared of inhabitants, being now only used for meadow and grazing. About 70 acres are wooded. The unpurchased part is moorland and rough grazing.

The Stonyford catchment area, 5 miles north-west of 


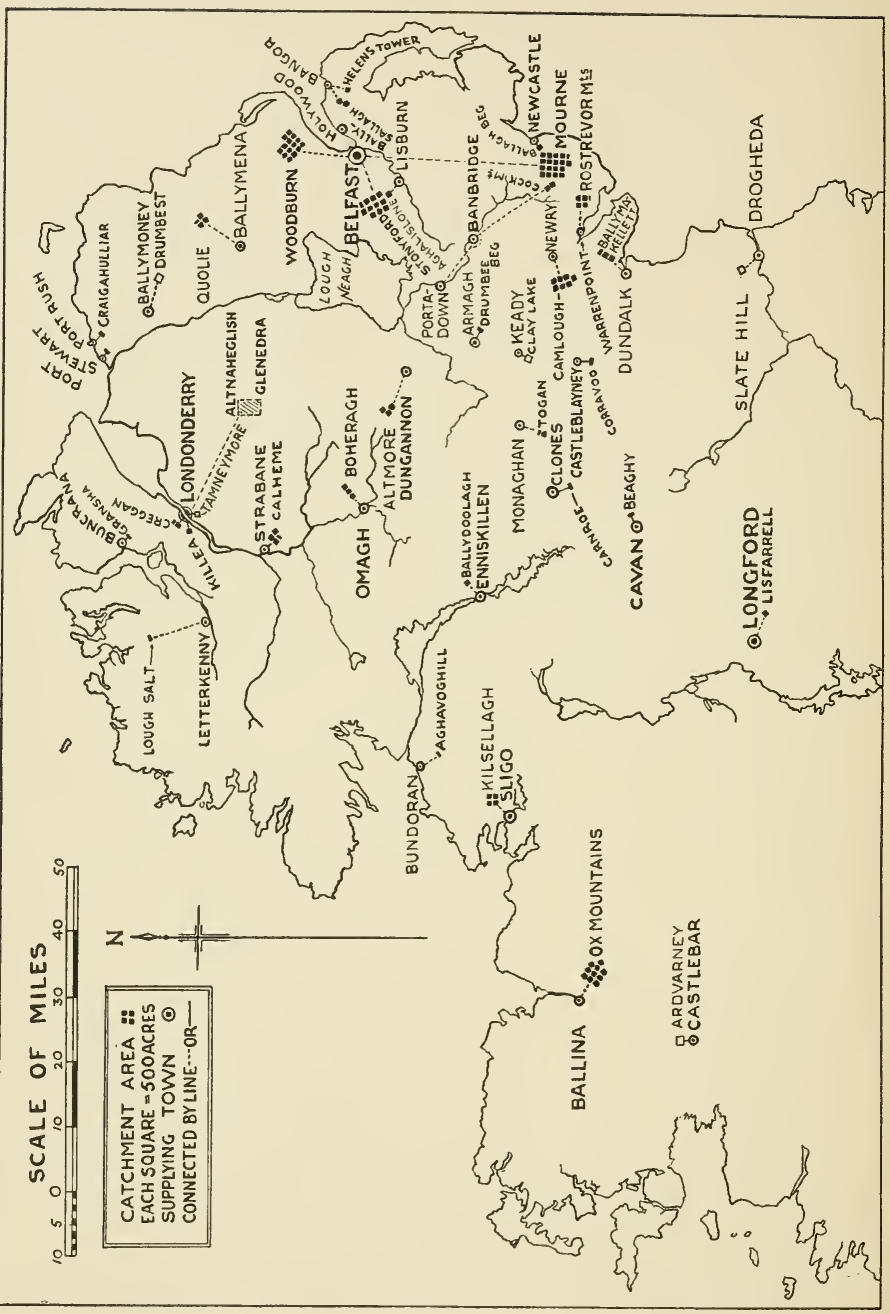


Lisburn, between 450 and 1085 feet elevation, contains 5348 acres, of which 1365 acres were purchased by the Commissioners and depopulated, being now used for meadow and grazing. The unpurchased part is moorland and rough mountain grazing. No part of this catchment area is wooded.

The Mourne catchment area, 33 miles south of Belfast and 5 miles from Kilkeel, at 450 to 2800 feet elevation, in the Happy Valley of the Mourne Mountains, contains 8724 acres, all of which has been purchased by the Commissioners. It consists of steep, treeless mountain slopes, without dwellings, on which only a few sheep can be grazed, and is above the agricultural zone. The water is filtered. No scheme for planting has been proposed; and Mr. R. Hamilton, Secretary, considers that " the bare rugged slopes of the Mourne area are incapable of being used with satisfactory results for the planting of trees."

Lisburn : gathering ground in Aghnahough, Aghalislone, and White Mountain, 476 acres, between 356 and 825 feet elevation, comprising 279 acres of arable land, 190 acres of mountain pasture, and 7 acres of plantations, with 22 farmhouses and 10 cottages. The Council own 28 $\frac{1}{2}$ acres, all arable. "The streams have been piped at points most liable to surface contamination, and receive constant inspection and supervision. There is no risk of contamination being brought by flood water or rains into the storage reservoir, which is situated between White Mountain and Lisburn. The water supply is filtered."

Ballymena : gathering ground on Quolie Mountain, 1723 acres, between 835 and 1250 feet elevation, all mountain grazing, without habitations or plantations. Council own none of the ground. No special precautions needed against contamination.

Ballymoney : from Lake Drumbest, $5 \frac{1}{2}$ miles distant, at 327 feet elevation. Council own only the bank surrounding the lake. The water is not filtered. 
Portrush : gathering ground of 350 acres, all arable land and pasture, between 200 and 425 feet elevation, in the townlands of Craigahulliar, Knockertotan, Slimag, Crossreagh, and Corbally. There are 8 dwelling-houses, with farm-steadings attached, on the area, no part of which is owned by the Council. "There are many springs on the area, which are carefully collected and piped to the reservoir. The drainage from some of the arable land and farm-steadings is rejected. Filtration is good."

Portstewart: gathering ground of $183 \frac{1}{2}$ acres in South Mullaghacall, Garrylaban, Cappagh Beg, East Crossreagh, and West Tullaghmurry townlands, between 50 and 150 feet elevation, all arable land except 2 acres of plantations, with two farmhouses upon it. No special measures to prevent contamination are taken on the gathering ground, none of which is owned by the Council; but the water is filtered.

Londonderry *: water supply from three sources:

1. Creggan Valley, about two miles west of the city; three reservoirs; catchment area of 650 acres, between 300 and 700 feet altitude, all agricultural land, with a number of inhabited houses.

2. Killea Valley, south-west of the last; storage reservoir; catchment area of 456 acres, largely hill grazing, but with some arable land.

3. Tamneymore, south of the city; two storage reservoirs; supply partly from springs situated in agricultural land, partly from perforated subsoil conduits in catchment areas.

The Corporation appear to own only the sites of the reservoirs. All reports show that the water supply is of doubtful quality, the areas being very liable to contamination.

The Londonderry Corporation have in Parliament during the present session (1918) a scheme for obtaining a new water supply from the Glens of Banagher, in the Sperrin Mountains. It is proposed to construct two reservoirs, one 
on the Glenedra Water and the other on the Altnaheglish River, not far above the point where they unite to form the Owenrigh River. The excellent catchment area, which it is proposed to acquire, is mountain land, free from habitations and any chance of contamination; and is situated in Carnabane, Templemoyle, Glenedra, and Teeavan townlands, comprising the basins of the Glenedra and Altnaheglish Rivers, and ranging in elevation from about 700 feet to 2170 feet, the latter being the altitude of Mullaghaneany.

Buncrana : gathering ground of 250 acres, at 250 to 800 feet elevation, in Gransha townland, all mountain grazing, with one dwelling-house; no filtration. Council own none of the ground.

Letterkenny : new supply from Lough Salt, a lake 73 acres in extent, at 816 feet elevation; no filtration necessary. Council own none of the catchment area, acreage of which is not stated.

Holywood : gathering ground of 424 acres in Ballykeel and Holywood townlands, between 350 and 664 feet elevation, comprising 380 acres of arable land, 30 acres of moss and rough grazing, and 14 acres of copse and shrubbery in a glen. There are 9 dwelling-houses, all with farm-steadings, on the gathering ground. The Council own 35 acres, and the measures against contamination include "collection of overflows from farmyards and irrigation of the lands farthest from the main feeders."

Bangor obtains its water supply from two gathering grounds :

(1) Helen's Tower area, 330 acres, between 213 and 400 feet elevation, comprising 80 acres of mountain grazing and 250 acres of plantations, with one dwelling-house upon it. (2) Ballysallagh area, 1026 acres, between 277 and 600 feet elevation, comprising 900 acres of arable land, 26 acres of hill pasture, and 100 acres of plantations, with 25 dwelling-houses upon it. The Council own no part of the 
two areas, which "are kept clean. During heavy rains no water is allowed to get into Ballysallagh reservoir."

Newcastle (Co. Down) obtains its water supply from a gathering ground of 500 acres, between 800 and 2515 feet elevation, in Ballaghbeg, embracing the upper $1 \frac{1}{4}$ mile of the Glen River, and all mountain grazing, without habitations or plantations. The water, coming off a granite formation, is very pure, and is piped from the intake at the 800 feet contour line to the service closed reservoir in Donard demesne. The water supply and gathering ground belong to Lady Mabel M. Annesley.

Portadown and Banbridge Joint Waterworks Board obtain their supply from a gathering ground of 943 acres, between 900 and 2300 feet elevation, in the townlands of Fofannyreagh, Fofannybane, Moyad, and Cock Mountain Common in the Mourne Mountains. The headwaters of the Shimna River are collected off this area by a dam thrown across the river at Deer's Meadow in Fofannyreagh, forming a storage reservoir, with a capacity of $75,000,000$ gallons. The Board own the entire area, which is all mountain grazing, without habitations or plantations. One of the streams supplying the reservoir is diverted past it in time of floods, being slightly peaty. The water is not filtered. The lower part of the gathering ground might possibly be afforested; but it is composed, according to Mr. R. H. Dorman, M.Inst.C.E., of steep and barren slopes of very little value even for sheep grazing. The average annual rainfall is estimated at 70 inches. See Proc. Assoc. Municipal and County Engineers, vol. xxxiii. pp. 133-143 (1907).

Warrenpoint: supply from gathering ground of 2694 acres in the townlands of Mourne Mountains West, Rostrevor Mountains, Killowen Mountains, and Kilfeaghan Upper, between 500 and 1800 feet elevation, all mountain grazing. None of the area, which is uninhabited, is owned by the Council. It is free from contamination, and the water is 
not filtered. The impounding reservoir is 9 miles distant from Warrenpoint.

Newry obtains its water supply from Camlough Lake, with a catchment area of 3407 acres, between 320 and 1385 feet elevation, situated in the townlands of Carrickbracken, Cross, Keggall, Ballinliss, Seafin, Tamnaghbane, Ballynalack, Aghmakane, Sturgan, and Carrickcloghan in Co. Armagh. The greater part of the area is mountain pasture, with 100 acres of plantations; but a considerable portion is arable land with a good many dwelling-houses upon it. As the area of the lake is 120 acres, with a storage capacity of $600,000,000$ gallons, it was supposed at first that the storage capacity was sufficient to purify the water without filtration; and at present the water is not filtered. Of recent years the conditions have changed, and a filtration scheme which was subrnitted to the Council by the Town Surveyor is held in abeyance by the war. The Council own none of the catchment area.

Armagh : gathering ground of 256 acres in Drumbee Beg, Drumbee More, Edenknappagh, and Killeen townlands, between 390 and 410 feet elevation, consisting of 128 acres of the Drumbee bog and 128 acres of arable land, with 13 cottages upon it. These houses have earth and dry closets. The water lying in the Drumbee bog is conveyed both by pipes and by an open water course to Lowry's Lake, having a surface area of 26 acres, which forms a storage reservoir. The water taken from the lake is filtered before reaching the town.

Keady : water supply from Clay Lake; catchment area, 605 feet elevation; acreage unknown; entirely arable land and pasture land with three or four farmhouses upon it. No measures are taken on the area against contamination.

Dungannon: gathering ground of 1500 acres, between 527 and 735 feet elevation, in Altmore and Knocknaclogha townlands, comprising 400 acres of arable land, 1080 acres 
of mountain grazing, and 20 acres of plantations. There are 11 dwelling-houses, a school, and a church upon the gathering ground, none of which is owned by the Council. "Contaminated water is either conveyed in concrete channels past the reservoir and discharged on grass land or is piped into Altmore stream, which passes the reservoir."

Omagh: gathering ground of 1600 acres, between 450 and 1500 feet elevation in Boheragh, Glenhordial, Crosh, Belnagilly, and Faccary townlands, all mountain grazing, and with only one habitation, a herd's house, upon it. No measures against contamination are deemed necessary on the gathering ground, none of which is owned by the Council.

Strabane : gathering ground of 1780 acres, between 450 and 500 feet elevation, in Calheme, Knockavoe, Evish, and Cavanalee townlands, comprising 1280 acres of mountain grazing and 500 acres of arable land, with 52 dwellinghouses upon it. No measures are taken against contamination of the gathering ground, none of which is owned by the Council. Settling tanks and filtration are used at the waterworks near the town.

Monaghan: gathering ground of 813 acres, in Togan, Ballagh, Drumsheeny, Gortnana, Leck, Corcaghan, Greagh, Cavanagarvan, Tattinclieve, Blackraw, and Drumlinny townlands, between 460 and 600 feet elevation, comprising 100 acres of mountain grazing and 713 acres of arable land, with about 25 farmers' dwelling-houses. The Council own none of the land on the area, but have purchased one house to prevent contamination. A caretaker is employed to guard against contamination, and legal proceedings are instituted when necessary.

Clones: gathering ground of 120 acres in Carnroe, between 300 and 400 feet elevation, comprising 70 acres of arable land, 40 acres of hill grazing, and 10 acres of plantations, and with three dwelling-houses on it. The supply is piped beyond these houses to prevent sewage from 
the farmsteads getting into the reservoir. The Council own only 3 acres.

Castleblayney : gathering ground of 93 acres, all arable land, in Corravoo, Cargaghdoo, and Annagleve townlands, between 645 and 705 feet elevation. The Council own only the reservoir site, about 1 acre. On the area there are 5 farmhouses, the sewage from which is drained outside it.

Enniskillen: gathering ground of 400 acres, in Ballydoolagh, Cooltrain, Lissan, and Largy townlands, between 443 and 701 feet elevation, comprising 56 acres of mountain grazing, whins, and bog, and 344 acres of arable land, with 11 occupied houses, there being 6 whole farms and 14 portions of farms on the area. The water is not filtered, but is passed through gauze screens at a sluicehouse close to the lake (or storage reservoir), and again through gauze screens at the service reservoir, one mile distant. No special precautions are taken against contamination on the gathering ground, of which only $1 \frac{1}{2}$ acre is owned by the Council.

Cavan: gathering ground of 270 acres in Beaghy, Shankill Lower, Corranure, Stragelliff, Drumcrauve, Billis, and Corragho townlands, between 324 and 465 feet elevation, all arable land, except 10 acres of mountain grazing, and with 20 farmhouses upon it. The Council own only 6 acres, being a swamp in which water is stored at a high level for the purpose of scraping the mains by pressure. No special measures are taken on the gathering ground to prevent contamination, but the water is screened at the inlet house, and filtered near the town where there is a reservoir.

\section{LEINSTER}

Gathering grounds, 29,290 acres, supplying eight local authorities (acreage of Drogheda, Tullamore, and Wexford gathering grounds unknown and not included). 418 
acres (reservoirs not included) owned by three local authorities.

Dublin obtains its water supply from the Roundwood reservoir in Co. Wicklow, which is situated on the Vartry Piver, at an elevation of 693 feet above sea-level. The catchment area, 13,700 acres in extent, consists maiuly of a plateau between 700 and 900 feet elevation, but extends on the west to a chain of mountains ranging from 1580 to 2384 feet, the highest point being the summit of Douce, while on the east it ascends to a ridge varying between 800 and 1200 feet elevation. The Corporation own 550 acres here, comprising the reservoir with 409 acres of water surface and 141 acres of filter beds and other adjoining land. A second reservoir, in course of construction on the river Vartry higher up, has a gathering ground of 9000 acres, being part of the 13,700 acres already mentioned, as the catchment area has not been increased. The Corporation have acquired here 510 acres, comprising the site of the new reservoir, which will have 303 acres of water surface and 207 acres of adjoining land. The catchment area, mainly hill pasture and moorland, with a small proportion of arable land, is sparsely populated, the few dwellings being small farmhouses or labourers' cottages, with no drainage system. The village of lioundwood is technically within the catchment area, but the entire drainage is intercepted and diverted by an open cutting, which discharges into the river Vartry below the filter beds. The Corporation have had under consideration the desirability of acquiring the whole catchment area, but it was considered unnecessary to do so. "The Vartry water is very pure. It is chemically examined every day, and the results rarely show any variation, the highest standard of purity being maintained."

On the land owned by the Corporation around the old reservoir 50 acres of plantations were made about 45 years ago. These have been very valuable for shelter and ornament. The timber is now coming into use for fencing, 


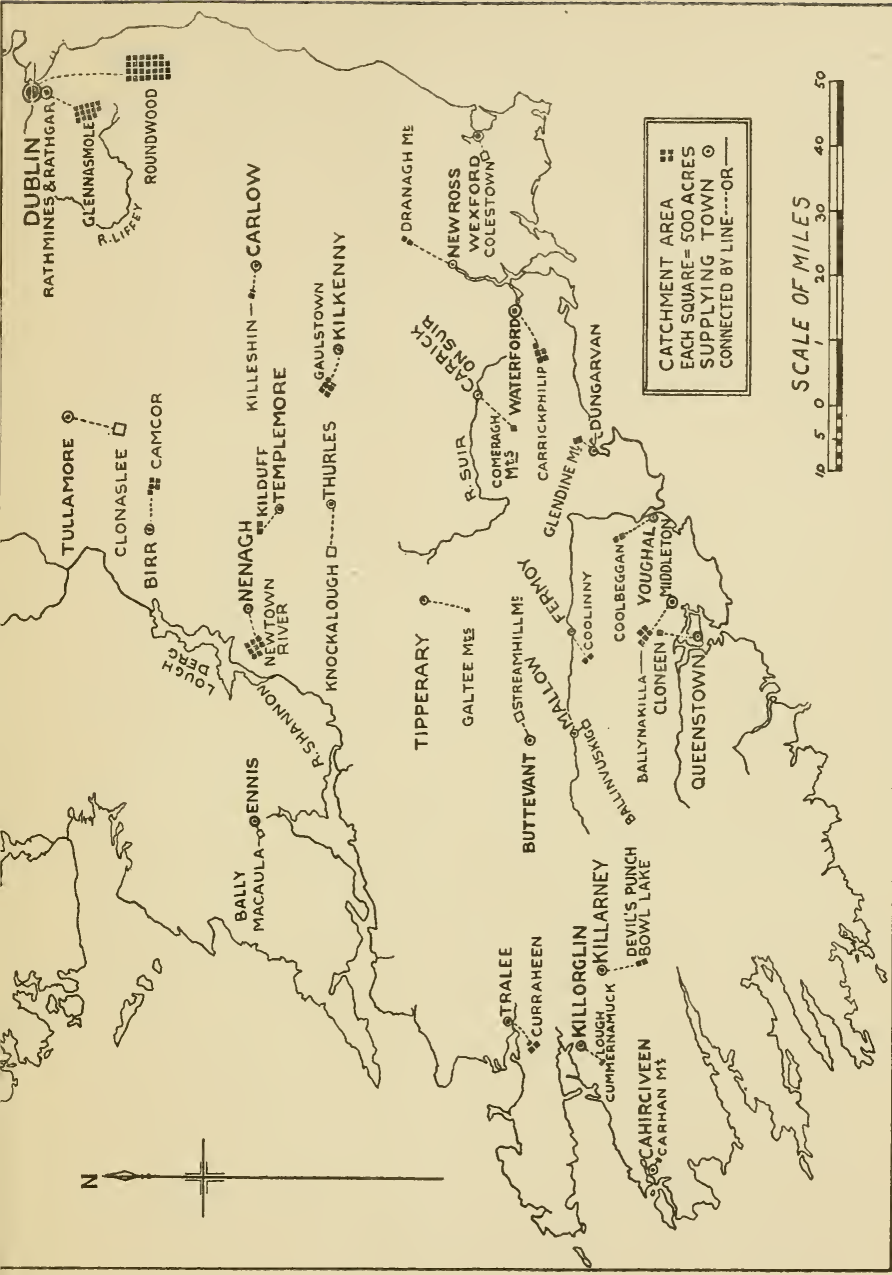

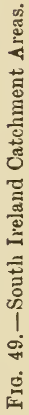


gates, and other purposes. A nursery, two acres in extent, has recently been established. A scheme for planting 146 acres on the grounds of the new reservoir has been sanctioned by the Waterworks Committee of the Corporation, and about 5 acres have been planted up to date. It was stated in the Freeman's Journal, 1st August 1913, that "an afforestation application had been made to the Development Commissioners for funds for the afforestation of the water catchment area at Roundwood"; but I can obtain no confirmation of this. An account of the Roundwood Waterworks, with map of the catchment area, by J. G. O'Sullivan, appeared in Trans. Inst. C.E., Ireland, xxxiv. pp. 94-120 (1908).

Rathmines and Rathgar Urban District Council have a gathering ground of 7000 acres in the Dublin Mountains, in the Glennasmol Valley, comprising the headwaters of the river Dodder and its tributaries, the Slade and Cot Brooks, and situated in Allagour, Ballymorefinn, Glassavullaun, Castlekelly, Cunard, Glassamucky, and Piperstown townlands, extending from about 600 feet up to 2472 feet, the summit of Kippure Mountain. The gathering ground is made up of two distinct areas : an upper area of 4000 acres, practically all moorland, covered with peat and large boulders, the supply from which is used only for compensation water to millowners along the river Dodder. On this area there are three farm-steadings, with one dwelling-house and a shooting-lodge. The lower area, 3000 acres in extent, consists of bare mountain slopes free from peat and only suitable for grazing, but has 65 farm-steadings, with a dwelling-house attached to each, upon it. It is off the latter area that clear water is collected into the upper reservoir (at 578 feet elevation) for drinking purposes. The lower or millowners' compensation reservoir has a topwater level of 495 feet elevation. The service reservoir at Ballyboden with filter beds is at an elevation of 327 feet. See map and description of these waterworks by F. P. Dixon, M.Inst.C.E., in British Association Handbook to 
Dublin, pp. 392, 393 (1908). Mr. Dixon gives the acreage of the catchment area as follows: Upper area, 4340 acres; lower area, 3250 acres; or a total of 7590 acres. The Council own between 50 and 60 acres at the lower level of the gathering ground. "The measures taken against contamination are regular inspection of streams, cleaning catchwater channels and keeping these free of vegetation and debris, and provision of pipe drains separating the farm drainage from the spring water." The Council, beginning in 1900 , have planted nearly 50 acres, about 80,000 larch, pine, alder, and birch trees being used. The timber is already valuable, some of the trees having been cut down and employed for fencing as required.

Dundalk : gathering ground of 1200 acres in Ballymakellett and Doolargy townlands, in the Carlingford Mountains, between 400 and 1563 feet elevation, all mountain pasture and moorland, except 50 acres of arable land, which has four houses upon it. The Council own the river beds and the valve towers only. The gathering ground is regularly patrolled by a water keeper, and the water is stored in a reservoir of $32,500,000$ gallons capacity.

Drogheda : gathering ground in Slate Hill, Tullyeskar, Barnattin, and Killineer townlands, two miles N.N.W. of Drogheda, acreage not ascertained, all arable land with five farmhouses upon it. The Council own only 10 acres around the reservoirs, of which 5 acres have been recently planted. The Council have not control over the gathering ground; but the water is filtered, and there is a special sewage system for Barnattin hamlet.

Longford ${ }^{*}$ : supply from stream at Lisfarrell, 315 feet elevation, with a gathering ground of 600 acres of arable land and pasture lands, with several farmhouses upon it. Pond and filters.

Tullamore* : supply from Clodiagh River at Clonaslee, 400 feet altitude. Large catchment area, acreage un- 
known, of arable and pasture land, with several houses upon it. The water is filtered.

Birr* : supply from the headwaters of Camcor River in Ballyshane townland, at 394 feet elevation. Catchment area of 2490 acres, two-thirds being mountain pasture, with nine houses, the drains of which are intercepted. The Council own none of the ground. The water is filtered.

Kilkenny: gathering ground of 2700 acres north-east of the city, in Gaulstown, Cloghpook, Wildfield, and Knockmajor townlands, between 500 and 1000 feet elevation, consisting of 400 acres of arable land and 2300 acres of mountain grazing, with 20 farmsteads upon it. The drainage of the 5 farmsteads nearest the reservoir on the main stream is intercepted and passed through a tank and over grassland before entering the stream. The Council own none of the land.

Carlow*: reservoir on Killeshin stream in Keeloge townland, Queen's County, 3 miles west of Carlow, at 240 feet elevation; catchment area of 700 acres, with 14 houses upon it. The Council own none of the land. The water is filtered.

New Ross : gathering ground of 900 acres, all mountain grazing without habitations, between 400 and 1080 feet elevation on Dranagh Mountain and Bantry Commons, on the headwaters of the river Drummin. The Council own none of the ground, which is practically all common land. There is no risk of contamination, and the water is filtered.

Wexford * supply from reservoir on stream at Colestown, at 263 feet elevation, $2 \frac{1}{2}$ miles west of the town. No other information obtainable.

\section{MUnSTER}

Gathering grounds, 16,152 acres, supplying fourteen local authorities (acreage of Thurles, Mallow, and Ennis 
gathering grounds unknown and not included). One hundred and twelve acres owned by two local authorities.

Nenagh : gathering ground of about 4000 acres, on the headwaters of the Newtown River, between 300 and 1517 feet elevation, extending from the reservoir east of Pallas More, westward to Tountinna Mountain, and comprising 2400 acres of arable land in grass, 1500 acres of mountain pasture, and 100 acres of plantations. There are 12 dwelling-houses on the gathering ground, all at a considerable distance from the stream; and in the opinion of the County Surveyor the area is so free from pollution that the water supply does not require filtration. The Council own none of the gathering ground.

Templemore: supply from Kilduff stream at 672 feet elevation; gathering ground of 1000 acres, between 700 and 1200 feet elevation, comprising 900 acres of mountain grazing and 100 acres of plantations, with four dwellinghouses. Intercepting drains at Kilwardy House discharge below the reservoir. The Council own none of the gathering ground. The water is filtered.

Thurles : supply from small stream and adjoining springs in Knockalough townland, 7 miles west of the town, at 975 feet elevation; area of gathering ground unknown. The Council own $2 \frac{1}{2}$ acres. The water is filtered.

Tipperary : gathering ground from springs at 1952 feet elevation in Galtee Mountains, oozing from a moraine beside a lake; catchment area 20 acres, not owned by the Council. Water very pure and no risk of contamination. Large plantation below the gathering ground.

Carrick-on-Suir: gathering ground of 400 acres in Comeragh Mountains, Co. Waterford, at Crotty's Lake, between 700 and 2400 feet elevation, all mountain pasture, without dwelling-houses or farmsteads. Only six well sites, covering less than $\frac{1}{4}$ acre, are owned by the Council. The supply is from springs, and no filtration is required. 
Waterford : gathering ground of 2400 acres in Carrickphilip, Knockaderry, Cronolish, Caheruane, Ballyleen, Ballyrobin, Coolrattin, Smoor, and Ballycraddock townlands; all arable land (except 60 acres of turf bog), between 224 and 510 feet elevation. The Borough own 82 acres under reservoir at Knockaderry and plantations. There are 14 farm holdings and labourers' cottages on the gathering ground. The farms have the right of water for cattle, so special precautions against contamination are not taken.

Dungarvan * intake from stream at 194 feet elevation, with gathering ground of 675 acres in Glendine Mountain in Ballintoor and Deelish townlands, mountain grazing with one house upon it. The Council own nome of the land. The water is filtered.

Youghal : gathering ground of 1077 acres, 7 miles distant, in Coolbeggan townland, between 400 and 500 feet elevation, comprising 977 acres of mountain grazing and 100 acres of arable land. The Council own only the site of the filter beds, about $\frac{1}{2}$ acre. There are 5 or 6 farmsteads on the gathering ground, but the danger of contamination from these is said to be slight, owing to the small proportion of arable land and the great extent of poorly grazed mountain waste, with marshy land in the valley.

Middleton: gathering ground of 2481 acres in Ballynakilla, Ballynabrannagh, Ballyvatta, Clash, Condonstown, Dooneen, Glengarriff, and Leamlara townlands, between 200 and 600 feet elevation, all arable land, except 10 acres of plantations. There are 35 dwelling-houses and 64 farm holdings on the area, none of which is owned by the Council. No measures are taken against contamination on the gathering ground, but the water is filtered.

Queenstown : gathering ground of 476 acres in Cloneen, Tibbotstown, and Ballynakilla townlands, north of Carrigtohill, between 415 feet (level of the reservoir) and 527 feet 
elevation, comprising 370 acres of arable land, 74 acres of boggy land, 15 acres of plantations, and 16 acres under water. On the gathering ground, none of which is owned by the Council except the 16 acres of reservoir sites, there are 2 labourers' cottages and 11 farmsteads, with 59 inhabitants. The water leaves the reservoirs through copper screens, and passes by pipes to the filter beds. No special measures are taken on the gathering ground against contamination.

Fermoy: supply from a stream which enters the reservoir (450 feet elevation) and filter beds at Knockananig, three miles S.E. of the town. Supplemental supply from Glashmahall River, intake at Coolinny (539 feet elevation), with 1000 acres of gathering ground. The Urban District Council own here as freehold about 30 acres of uncultivated ground, said to be suitable for planting trees.

Mallow : supply from Fiddane stream at 485 feet elevation, in Ballinvuskig townland, about $2 \frac{1}{2}$ miles S.E. of the town. The catchment area consists of arable and pasture land, the acreage of which is unknown. The reservoir and adjoining land, about $1 \frac{1}{2}$ acres, on which it is proposed to construct filter beds, are owned by the Urban District Council. "The reservoir is cleaned out every four years."

Buttevant : supply from intake at 640 feet elevation on Streamhill Mountain, with 5-inch delivery pipe to reservoir, $\frac{1}{2}$ mile distant from the town. Catchment area extensive, acreage unknown. The Mallow Rural District Council own only intake works and reservoir, about $\frac{1}{2}$ acre in all.

Tralee : gathering ground of 1340 acres in Curraheen and Derrymore East townlands, between 200 and 2750 feet elevation, all mountain grazing, without habitations or plantations. The Council own only the sites of the intakes, reservoirs, and filters; and no precautions are considered necessary on the gathering ground except inspection after floods to remove dead sheep, etc. Efforts have been made 
to induce the Council to acquire the land and plant it with trees, but legal and financial obstacles, as well as apathy, have prevented any steps being taken, though on the catchment area there are extensive inountain tracts of land said to be suitable for nothing else but afforestation.

Killorglin: water supply from Loch Cummernamuck, with a catchment area of 250 acres, between 421 and 600 feet elevation, all monntain grazing, without habitations or plantations. The water supply is under control of the Killarney Rural District Council and a Waterworks Committee in Killorglin, who own only the site of the reservoir, and have rights and wayleaves for pipes and works. Cattle have access to the intake, and the supply is said to be unsatisfactory.

Killarney : water supply from Devil's Punch Bowl Lake, at 2206 feet elevation on Mangerton, the intake being on a stream in Ferta townland, 550 feet above the level of the town, with a catchment area of 914 acres, all mountain grazing, without habitations or plantations. The Council have a right to the water from the lake, but own none of the catchment area. No precautions are considered necessary, as there are screens at the intake to exclude leaves, etc., from getting into the pipes, which lead to the service reservoir and filters. It is a perfectly pure and ample supply.

Cahirciveen : gathering ground of 120 acres on Carhan Mountain, south-east of the town, between 373 feet (level of the intake) and 1000 feet elevation, all mountain grazing and without habitations or plantations. The Rural District Council own the site of the reservoir and intake, and have purchased water rights and wayleaves on the mountain. Covered drains convey the water from the springs on the gathering ground to the intake, but the springs are liable to be interfered with by grazing cattle. The area is said to be suitable for afforestation, and the pipes from the 
intake pass through Carhan Wood, which has lately been cut down.

Ennis* : supply from stream at Ballymacaula at 228 feet elevation. Gathering ground of tillage and pasture land at a low elevation. Other particulars not obtainable.

\section{Connaught}

Gathering grounds, 7140 acres, supplying three local authorities (acreage of Castlebar gathering ground unknown and not included). Nil acres owned by local authorities.

Bundoran : gathering ground of 140 acres, at 800 to 1000 feet elevation, in Aghavoghill townland, Co. Leitrim; all mountain grazing; no habitations; Council own none of the ground.

Sligo* : supply from Kilsellagh, at 395 feet elevation; gathering ground of 2000 acres of arable land and pasture land, with 40 houses upon it. Pond and filters.

Ballina : gathering ground of 5000 acres in the $\mathrm{Ox}$ Mountains, between 136 and 1000 feet elevation, in Graffy, Lissardmore, Ellaghmore, Ellaghbeg, and Bunnyconnellan townlands. The gathering ground comprises 1800 acres of arable land and 3200 acres of mountain grazing, with about 130 farmsteads upon it. None of the land is owned by the Council, and no measures are taken against contamination.

Castlebar: supply from river and springs in Ardvarney townland at 300 feet elevation; gathering ground extensive, but with few houses. The river is fenced near the intake, and the water is filtered. The Council own none of the area. 



\section{IN D E X}

Abies grandis, 130

Abies nobilis, 93, 130

Abies pectinata, 128

Acacia, so-called, 50, 169

Acer, species of, 51, 156

Aesculus, species of, 51

Afforestation of pit mounds, 59

Afforestation of water catchment areas, 71,105

Agrarian zone, 106

Ailanthus glandulosa, 50

Air of forests, 16

Air, pure bracing, 17

Alder, common, 63, 154

Alder, grey or white, 68,155

Alnus, species of, $63,68,154,155$

Altitude and cultivation, 117

Altitude and planting, 115

Altitude, effect on trees, 113

Ardgoil Estate, 41

Ash, 50, 119, 149

Ashgill Plantation, 115, 138

Aspen, 166

Bacteria in air of forests, 17

Barr, W., 19

Bates, C. G., 12

Baxter, George, 81, 282

Beeeh, 47, 98, 119, 147

Betts, Norman D. W., 11

Betula, speeies of, 163

Birch, 49, 63, 162

Birmingham parks, 35

Black Country, 59

Board of Agriculture, 86, 103

Boodle, L. A., 19

Bournemouth pine plantations, 24, 126

Bracken ferı, 15, 108

Broad-leaved trees, 119, 120, 14 ;

Brompton Hospital Sanatorium, 22
Cairns covered by peat, 19

Camps afforestation scheme, 27, 261

Castanea, 157

Catalpa, 53

Chestnut, 157

Chittenden, H. M., 2

Cholera, forests free from, 17

Church, J. E., 5

Climate, forests and, 1

Climate, optimum, in Neolithic period, 19

Common land, 39, 103, 107

Conifer forests and tubereulosis, 22

Conifer plantations, 120, 148

Conifers in towns, 54

Conifers for planting, 119, 123

Cotton grass moor, 111

Cricket-bat willow, 168

Cupressus lawsoniana, 19, 146

Cupressus macrocarpa, 19, 146

Dairy farms and shelter belts, 18, 19

Deschampsia flexuosa, 108

Development Commissioners, 31, 62, $79,89,103,188,228,239$, 267,298

Dobell, Dr. Horace, 23, 25

Don and Chisholm, 19

Douglas fir, 42, 94, 98, 131

Doulton Road Schools, 64

Draining effected by forests, 16

Ebermayer, 15, 17

Elms, 52, 159

Eriophorum, 111

Erosion of soil and forests, 1, 7

Etlinger, Dr. F. K., 22

Eucalyptus and malaria, 16

Enonymus japoniea, 19

Eve, Prof. A. S., 17 
Exmoor, plantations on, 116

Exposure and planting, 105, 116

Fernow, E. B., 11

Fescue, 108

Filtration of water supply, 104, 226

Fisher, W. R., 96

Floods diminished by forests, 7,9

Forest air, 16

Forest influence-

on air temperature, 3

on climate, 1

on erosion of the soil, 1,7

on floods, $7,8,9$

on flow of streams, 10

on rainfall, 3

on silting of reservoirs, 76

on snow melting, 5

on soil temperature, 3

on springs, 7

on water supply, 6

Forestry societies and schools, 66

Forestry work at Hairmyres for tuberculous patients, 28

Forests-

absence of, on west coast, 114

aesthetic value of, 18

and elimate, 1

and hygiene, 13

and undergromd water, 16

as sites for sanatoria, 20

bacteria in air and soil of, 17

drainage by, improving health, 16

of conifers and tuberculosis, 22, 26

on mountain water'slieds, 9

sanitary influence of, 13

villages in, free from cholera, 17

Fraxinus excelsior, 50, 119, 149

Frosts, spring, and peat-bogs, 15

Furze, 108

Games, organised, in parks, $3 \pi$

Gathering gromnds. See Water catchment areas

Giandotti, MI., 2

Ginkgo biloba, 55

Glasgow Municipal Forest, 41

Gordon, G. P., 31, 32

Gordon, Dr. W., 14

Grauts for afforestation, 80

Grass mools, 111

Grazing, zone of hill, 106

Grazing in larch plantations, 117
Hairmyres Colony Sanatorium, 27

Hairmyres forest nursery, 28

Hall and Maxwell, 8

Hamburger, Prof., 25

Hardie, Dr. M., 114

Hawes, Austin F., 11

Hay fever, 20

Hazel, 150

Health and forests, 18

Heather, 109

Heaths, 106, 109

Hemlock spruce, 144

Henzell, C. G., 100

Hill pasture, 106, 117

Hill, Prof. Leonard, 22

Hinsdale, Dr. Guy, 32

Hollies for towns, 54

Holmes, Basil, 38

Hornbean, 157

Horse chestunt, 51

Huffel, G., 12, 17

Hybrid trees, 121

Hydrogen peroxide, 16

Ilex, hybrids of, 54

India, forest influence on climate of, 2

Interplanting, 134

Ionisation of forest air, 17

Juglans nigra, 47, 168

Juncus, 111

Kellogg, Frank B., 18

Knockboy plantation, 127

Laburmum, 53

Lanark, afforestation scheme at Camps, 29

Landes, forests of, iniproving health, 18

Larch-

European, 15, 93, 98, 139

Japanese, 142

western, 143

woods and grazing, 117

Laurel, 19

Law'son eypress, 19, 146

Lawson, Dr. David, 22

Lees, E. A., 103

Leighton, M. O., 8

Lime trees, sprecies of, 51

Liquidambar, 53

Loomis, Dr. A. L., 21 
Maidenhair tree, 55

Malaria diminished by forests, 16 , 18

Maple, Norway, 51, 156

Margerison, S., 76

Mathieu, A., 11

Metropolitan Public Gardens Association, 39

Midland Reafforesting Association, 59

Mill, Dr. Hugh R., 2

Mitchell, L., 187

Molinia caerulea, 108, 111

Moorland zone, 109

Moors, planting of, 112

Mulberry, 53

Municipal forests, 41

Nancy, observations on forests and rainfall at, 4,16

Nardus stricta, 108, 111

National Trust, 40

New Forest, rainfall of, 2

Nordrach Colonie Sanatorium, 21

Nordrach-on-Dee Sanatorinm, 22

Oak-

common, 53, 152

evergreen, $54,154,156$

Turkey, 154

Oaks for towns, 53

Oil shale, 69,70

Open spaces, 33

Oppokov, E. V., 9

Oxygen in air of forests, 15

Ozone in air of forests, 16

Pan, 110

Parks-

in towns, 33

purity of air in, 18

of Birmingham, 35

of London, 33

Parry, J., 72, 80, 84

Paulownia imperialis, 47

Peat-

bogs, afforestation of, 15, 19

bogs, chilling effect of, 15

formation of, 19, 111

moors, 111, 112

on mountains, 14

planting on, 15, 112, 138, 194

Pennines, 108, 109

Phagocytosis, 25

Phthisis, 20, 23
Pine-

Austrian, 54, 98, 125

Corsican, 54, 93, 98, 124

forests and sanatoria, 21

leaves, chemical constituents of, 25

maritime, $15,19,125$

needle oil, 25

plantations at Bournemonth, 24

Scots, 15, 98, 120, 123

Weymouth, 93

Pines, emanations of leaves of, 25

Pines, odours of, 25

Pinus insignis, 127

Pinus montana, 126

Pit banks and bings, $60,68,70$

Pit mounds-

afforestation of, $59,67,155$

sowing of, 62,67

trees for, 63,155

Plane, various species, 48

Plantations-

Ardgoil, 41

Elan, 102

Exmoor, 116

Rivington, 95

Thirlmere, 96

Vyrnwy, 92

Washburn Valley, 100

Planting-

at high elevations, 115

mattock used in, 98

on peat, $15,112,138,194$

on pit banks, 60,155

on water catchment areas, 85

trees in towns, 55

wet spots, 127,154

Platanus, several species, 48

Playground movement in America, 42

Playgrounds in towns, 39, 40

Pliny, treatment of tuberculosis, 20

Poplars, 49, 63, 121, 164

Populus, various species, 49, 121, 164

Proceeds-sharing, 80

Pruning of trees, 56

Prunus, species of, 53

Pyrus, species of, 53

Quercus, species of, 53,154

Rainfall, influence of forests on, 3

Reconstruction Report on Forestry, 79,86 
Reservoirs-

dead leaves in, 76,217

protection of, by tree belts, 76

silting of, 76

Return as to Water Undertakings in England and Wales, 104, 170

Rigg, G. B., 19

Rights of grazing, 103

Roberts, C. H., 10

Robinia Pseudacacia, 50, 65, 69, 169

Rowley Regis School Plantation, 65

Run-off water, 6

Ruskin, 73

Salix, various species, 167

Sallow, 167

Salt spray carried inland, 19

Salt spray, injury to trees, 13,19

Sanatoria in forests, 20

Sanatorium-

Brompton Hospital, Frimley, 21, 22

at Hairmyres, 27

at Nordrach, 21

Nordrach-on-Dee, 22

Pinewood, Wokingham, 22

Sand dunes, afforestation of, 19, 124, 126

Sanitary infiuence of forests, 13

School forestry societies, 66

School plantations, 62, 64

Scirpus moor, 111

Scots pine, 15, 98, 120, 123

Seed, selection of, 122,141

Shale banks, planting of, 69

Sheep and shelter belts, 15

Sheep in larch woods, 117

Sheep on water catchment areas, 74

Shelter belts, $14,24,129,139,147$, 148,156

Shelter for dairy farms, 18

Shelter of grazing land, 18, 19, 117, 118

Shelter of sanatoria, 24

Silver fir, 93, 128

Slag heaps, 60,69

Smoke, effect on trees, 45, 57, 95

Smoke of towns, 45,178

Snow, influence of forests on, 5

Soil erosion, forest influence on, 1,7

Soil in towns, 45

Soot and trees, 45, 54

Sowing on pit mounds, 62

Special adaptability, 82

Sphagnum moor, 111
Springs, forcst influence on, 7

Spruce-...

at high elevation, 31

common, $15,76,93,134$

Sitka, 94, 98, 136

white, 115,138

Staking trees, 55

Stevenson, R. L., 11

Stomata of leaves and soot, 54

Story, Prof. Fraser, 234, 239

Stream-flow, forest influence on, 10

Streets, planting of, 55

trees for, 47

Sulphur dioxide and trees, 45, 58

Sycamore, 51, 63, 156

Tarred roads and trees, 46,58

Temperature, influence of forests on, 3

Thomson, Prof. James, 34

Thuya gigantea, $19,42,93,133$, 145

Tilia, species of, 51

Timber line, 115

Town Planning Act, 38

Towns, parks in, 33

Towns, trees for, 48

Transpiration of oak forest, 3

Tree limit, 113

Trees-

and altitude, 113

and chemical works, 58

choice of, 120

damaged by shale industry, 69,70

damaged by soot and smoke, 45 , 57,95

for water catchment areas, 119

in towns, 44, 47

injury by salt spray, 13

leaves of, injured by wind, 19

preservation of, 56

wind effect on, 13

Tsuga albertiana, 144

Tuberculosis, sanatoria for, 21

Tulip tree, 47

Turpentine, effect on phagocytosis, 26

Typhoid cases and water supply, 77

Ulex, 108

Ulmus, species of, 52,160

Underplanting, 144, 146, 157

Unemployed, planting by the, 87 , 100,195 
Vegetation zones, 106, 117

Walker, Dr. Gilbert, 2

Walnut, black, 47, 168

Walther, Dr., 21, 22

Waste land, 106

Water Catchment Areas-

Aberdeenshire, 282

abolition of habitations and farms on, 73,188

afforestation of, $71,75,86,105$, 282

arguments for planting, 75,81

Argyllshire, 249

at low altitudes, 172, 204, 212

Belmont, 188

Bute, 249

bye-laws for, 214, 238

Camps, Mid-Lanark, 27, 261

Cheshire, 206

Clackmannan, 272

compulsory purchase by Corporations, $73,82,247$

Cornwall, 218

Cumberland, 172

Derbyshire, 206

Development Commissioners' scheme for afforestation, 89

Devon, 218

Dumbartonshire, 249

Dumfriesshire, 254

Durham, 176

Elan and Claerwen, 101, 238

England, 171

exorbitant prices paid for, 82

extent of total, 78,88

extent owned by Corporations, 85 , 86,88

Fifeshire, 272

Forfarshire, 277

Glencorse, 264, 266

Glendevon, 279

Glenfinlas, 249

Glensherrup, 279

Gorbals, 86, 250

Inverness, 282

Ireland, 286

Kinross, 272

Kirkeudbrightshire, 254

Lake District, 172

Lanarkshire, 259

Lancashire, 178

Leicestershire, 212

Lincolnshire, 212
Water Catchment Areas (contd.) -

Lintrathen, 82, 282

Loch Arklet, 249

Loch Bradan, 257

Loch Katrine, 86, 249

Longdendale, 98, 206

municipal ownership of, 207,219 , $226,229,261,277$

Northamptonshire, 212

Northumberland, 176

Perthshire, 249, 277

planting, $75,76,105$

prevention of floods, 76

prevention of pollution, 71,77 . 187,238

purchase of, 73,77

Reconstruction Committee's recommendations, 79

Renfrew, 249

restrictious on, $227,238,277$

River Farg, 277, 278

Rivington, 94, 180

sanitary condition of, 214,238

Scotland, 247

Severn Basin, 218

sheep grazing on, 74

Slateford Burn, 277, 278

Stirlingshire, 259

Talla, 265, 268

Thirlmere, $73,95,172$

trees for, 119

utilisation of, 73

Vyrnwy, 88, 237

Wales, 230

Washburn Valley, 99

Westmorland, 172

Wigtownshire, 254

Yorkshire, 190

Water Catchment Areas supplying-

Aberdare U.D.C., 245

Abertillery and District, 221

A berystwyth, 237

Accrington District Gas and Water Board, 184

Airdrie, Coatbridge, and District, 264

Alexandria, Bonhill, and Jamestown District, 250

Alloa, 272

Annan, 258

Arbroath, 280

Ardrossan, 254

Armagh, 293

Ashton in Makerfield U.D.C., 189 
Water Catchment Areas supplying (contd.) -

Ashton under Lyme, Stalybridge, and Dunkinfield (District), 207

Aspatria, Silloth, and District, 172

Ayr, 256

Bacup, 186

Baildon U.D.C., 198

Ballina, 305

Ballymena, 289

Ballymoney, 289

Banbridge, 292

Bangor (Dow11), 291

Bangor (Wales), 232

Barnsley, 203

Barrow in Furness, 180

Bathgate District, 262

Batley, 202

Beith, 255

Belfast, 287

Birkenhead, 234

Birmingham, 101

Birr, 300

Blackburn, 195

Blairgowrie, Rattray, and Dist., 280

Bolton, 187

Bo'ness, 269

Boston Waterworks Co., 217

Bradford, 193

Brechin, 281

Bridge of Allan Water Co., 260

Bristol Waterworks Co., 221

Briton Ferry U.D.C., 244

Brymbo Water Co., 235

Brynmawr U.D.C., 241

Buncrana, 291

Bundoran, 305

Burley-in-Wharfedale U.D.C., 197

Burnley, 183

Burntisland, 274

Bury and District, 184

Buttevant, 303

Buxton U.D.C., 210

Cahirciveen, 304

Cardiff, 239

Carlisle, 172

Carlow, 300

Carnarvon, 232

Carnforth District Waterworks Co., 182

Carrick-on-Suir, 301

Castlebar, 305

Castleblayney, 295

Cavan, 295
Water Catchment Areas supplying (contd.)-

Cheltenham, 219

Chesterfield Gas and Water Board, 211

Chesterfield R.D.C., 211

Church Stretton U.D.C., 218

Cleator Moor U.D.C., 174

Cleveland Water Co., 205

Clowes, 294

Clydebank and District, 251

Colne, 182

Conway and Colwyn Bay, 233

Crieff, 280

Cupar (Fife), 275

Dalry, 255

Darwen, 189

Denny and Dunipace, 259

Derwent Valley Water Board, 210

Devomport, 226

Dewsbury and Heckmondwike, 203

Doncaster, 204

Drogheda, 299

Dublin, 296

Dumbarton, 251

Dumfries and Maxwelltown, 258

Dundalk, 299

Dundee, 281

Dunfermline, 279

Dunfermline District, 279

Dungannon, 293

Dungarvan, 302

Dunoon, 252

Duns, 271

Ebbw Vale U.D.C., 241

Edinburgh, 264

Ennis, 305

Enniskillen, 295

Exmouth U.D.C., 224

Falkirk and Larbert Trust, 260

Falmouth Waterworks Co., 229

Fermoy, 303

Forfar, 281

Fraserburgh, 283

Fulwood U.D.C., 182

Fylde Water Board, 181

Galashiels, 271

Girvan, 257

Glasgow, 249

Glossop, 209

Gloucester, 220

Glyncorwg U.D.C., 244

Grange U.D.C., 181

Grangemouth, 260 
Water Catchment Areas supplying (contd.) -

Greenock, 252

Guisborough Water Co., 205

Halifax, 199

Hamilton, 262

Harrogate, 192

Hawarden and District Waterworks Co., 236

Hawick, 271

Helensburgh, 250

Heywood and Middleton, 188

Higham Ferrars and Rushden, 214

Holyhead Waterworks Co., 230

Holywood, 291

Horwich U.D.C., 189

Huddersfield, 201

Inverness, 282

Inverurie, 285

Irvine and District, 255

Ivybridge U.D.C., 227

Keady, 293

Keighley, 198

Keith, 284

Kelso, 272

Kendal, 175

Kettering U.D.C., 214

Kilbirnie, 255

Kilkenny, 300

Killarney, 304

Killorglin, 304

Kilmarnock, 256

Kilsyth, 259

Kingussie, 283

Kirkcaldy and Dysart, 274

Kirkealdy District, 277

Kirkendbright, 258

Kirriemuir, 280

Lanark, 263

Lanarkshire Middle Ward, 29, 261

Lancaster', 181

Lauder, 271

Leeds, 99, 190

Leicester, 216

Letterkenny, 291

Leven, 275

Linlithgow County, Bathgate District, 262

Linlithgow County, Central District, 270

Linlithgow District, 269

Lisburn, 289

Liverpool, 88

Llandudno U.D.C., 233
Water Catchment Areas supplying (contd.) -

Llanelly, 238

Llanfairfechan U.D.C., 232

Llanidloes, 237

Llantrisant and Llantwitfardre R.D.C., 246

Loanhead, 269

Lochgelly, 272

Londonderry, 290

Longford, 299

Loughborough, 215

Macclesfield, 208

Machynlleth U.D.C., 237

Mallow, 303

Malvern U.D.C., 219

Manchester, 95

Margam U.D.C., 243

Melton Mowbray U.D.C., 216

Merthyr Tydfil, 240

Middleton, 302

Milford Haven U.D.C., 238

Millom U.D.C., 175

Monaghan, 294

Morley, 200

Morpeth, 176

Motherwell, 262

Mountain Ash U.D.C., 244

Nantwich U.D.C., 211

Neath, 243

Neath R.D.C., 241

Nelson, 183

Nenagh, 301

Newburgh, 276

Newcastle (Down), 292

Neweastle and Gateshead Water Co., 176

Newport (Mon.), 220

New Ross, 300

Newry, 293

Newtown and Llanllwchaiarn U.D.C., 237

Northampton, 212

North Berwick, 270

Okehampton, 228

Oldham, 202

Omagh, 294

Oswestry, 236

Otley U.D.C., 196

Padiham U.D.C., 183

Paignton U.D.C., 228

Paisley, 253

Penmaenmawr U.D.C., 232

Penrith U.D.C., 175 
Water Catchment Areas supplying (contd.) -

Penzance, 229

Peterhead, 284

Pittenweem and Anstruthers, 276

Plymouth, 224

Pontypridd and Rhondda, 244

Portadown and Banbridge, 292

Port Glasgow, 252

Portrush, 290

Portstewart, 290

Preston, 182

Prestonpans Water Trust, 270

Queenstown, 302

Rathmines and Rathgar U.D.C., 298

Renfrew First District, 253

Rhondda U.D.C., 245

Rhyl U.D.C., 233

Ripon, 192

Rochdale, 186

Rosyth, 279

Rothesay, 252

Ruabon Water Co., 235

St. Andrews, 276

St. Ives (Cornwall), 229

Scunthorpe U.D.C., 217

Sheffield, 203

Shipley U.D.C., 197

Skipton U.D.C., 195

Sligo, 305

South Molton, 224

Stirling, 259

Stirling Eastern Distriet, 261

Stockport, 207

Strabane, 294

Stranraer, 258

Stratford-on-A von, 219

Stratton and Bude U.D.C., 224

Swansea, 242

Tain, 283

Taunton, 222

Tees Valley Water Board, 190

Templemore, 301

Thirsk District Water Co., 205

Thurles, 301

Tipperary, 301

Todmorden, 200

Torquay, 227

Towyn U.D.C., 236

Tralee, 303

Tredegar U.D.C., 221
Water Catchment Areas supplying (contd.) -

Troon, Prestwick, and Ayrshire Special, 257

Tullamore, 299

Turriff, 284

Tynemouth, 176

Wakefield, 200

Warrenpoint, 292

Warrington, 189

Waterford, 302

Weardale and Consett Water Co., 177

Wellington (Salop) U.D.C., 218

Wemyss and Distriet, 275

Westmorland, South, R.D.C., 175

Wexford, 300

Wharfedale R.D.C., 197

Whitburn, 269

Whitehaven, 174

Wigan, 189

Wishaw, 263

Workington, 174

Wrexham and East Denbighshire Water Co., 234

Yeadon Waterworks Co., 205

Youghal, 302

Watersheds, deforestation of, 9

Water supply-

action of lead on, 194

filtration of, 104, 226

sources of, 71

storage as means of purification, 74,187

Watson, James, 82, 194

Wet spots, planting, 137, 154

Whin, 108

Whitton, James, 41, 43

Willow, varions species, 167

Wind-

effect on trees, 13

harmful in phthisis, 14

trees resisting, $19,54,124,128$, $129,147,162$

Yew, 19

Zon, R., 4

Zone, agrarian, 118

of hill pasture, 117

moorland, 117

Zones of vegetation, 106,117 


\section{ANIMAL LIFE AND HUMAN PROGRESS}

Edited by Arthur Dendy, D.Sc., F.R.S., Fellow of King's College and Professor of Zoology in the University of London.

Demy 8vo. $227+i x$ pages.

$10 \mathrm{~s} .6 \mathrm{~d}$. net.

\section{INFLUENCES OF GEOGRAPHIC ENVIRONMENT}

By E. C. Semple, Author of "American History and its Geographic Conditions."

Medium 8vo. 700 pages.

18s. net.

\section{OUTLINES OF EVOLUTIONARY BIOLOGY}

By Arthur Dendy, D.Sc., F.R.S., Professor of Zoology in the University of London (King's College); Zoological Secretary of the Linnean Society of London; Honorary Member of the New Zealand Institute; formerly Professor of Biology in the Canterbury College (University of New Zealand), and Professor of Zoology in the South African College, Cape Town.

Second Edition, enlarged. Fourth Impression, with a Glossary. Illustrated.

15s. net.

\section{INDIAN TREES}

An Account of Trees, Shrubs, Wooly Climbers, Bamboos and Palms, Indigenous or Commonly Cultivated in the British Indian Empire.

By Sir Dietrich Brandis, K.C.I.E., Ph.D., (Bomu) LL.D., (Edin.) F.R.S., F.L.S., F.R.G.S., and Hon. Member of the Royal Scottish Arboricultural Society, of the Society of American Foresters, and of the Pharmaceutical Society of Great Britain. Assisted by Indian Foresters.

10s. 6d. net.

\section{SOILS AND MANURES}

By J. Alan Murray, B.Se.

Illustrated. Extra crown $8 v 0$.

7s. 6d. net.

EUROPEAN ANIMALS: Their Geological History and their Geographical Distribution.

By R. F. ScharfF, B.Sc., Ph.1), F.L.S.

Illustrated. Demy $8 v o$.

7s. 6d. net.

THE LIVING PLANT: A Description and Interpretation of its Functions and Structure.

By William F. Ganong, Pli.D.

Illustrated. $465+$ xii pages.

$15 \mathrm{~s}$. net.

\section{ECONOMIC ZOOLOGY AND ENTOMOLOGY}

By Verion L. Kellogit and C. IV. Doane.

Crouen 8vo.

6s. 6d. net. 
4 





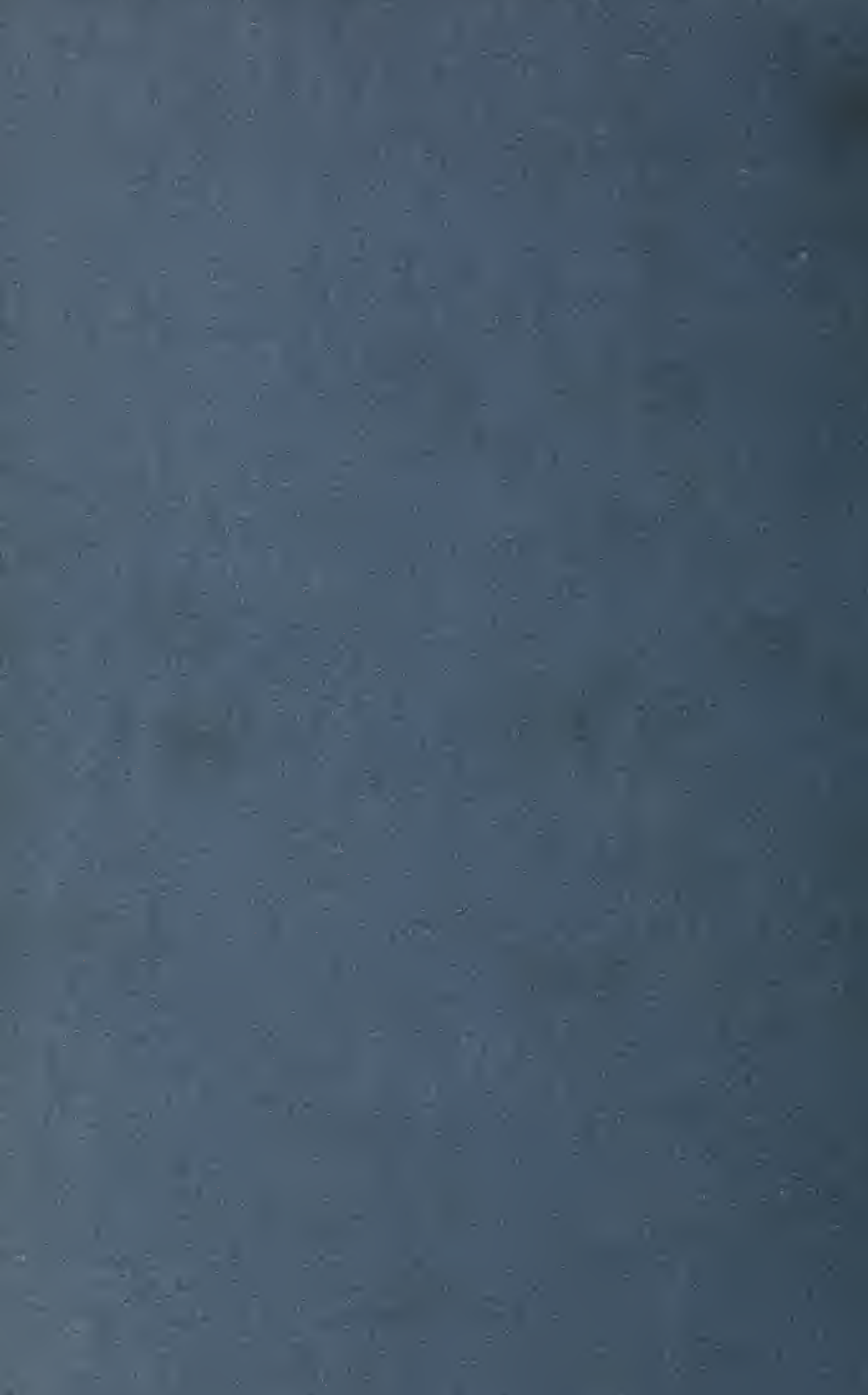

